RENATA MONTEIRO SIQUEIRA

\title{
A INSERÇÃO DA FAUUSP NO CAMPO DE AROUITETURA E URBANISMO EM SÃO PAULO: AS CONTRIBUIÇÕES DE ANHAIA MELLO E VILANOVA ARTIGAS.
}

Dissertação apresentada à Faculdade de Arquitetura e Urbanismo da Universidade de São Paulo como requisito para a obtenção do título de mestre em Arquitetura e Urbanismo.

ÁREA DE CONCENTRAÇÃO

Projeto, Espaço e Cultura

ORIENTADORA

Profa. Dra. Ana Cláudia Castilho Barone 
AUTORIZO A REPRODUÇÃO E DIVULGAÇÃO TOTAL OU PARCIAL DESTE TRABALHO, POR QUALQUER MEIO CONVENCIONAL OU ELETRÔNICO, PARA FINS DE ESTUDO E PESQUISA, DESDE QUE CITADA A FONTE.

E-MAIL DA AUTORA: renata.siqueira@usp.br

Siqueira, Renata Monteiro

S618i A inserção da FAUUSP no campo de arquitetura e urbanismo em São Paulo: as contribuições de Anhaia Mello e Vilanova Artigas / Renata Monteiro Siqueira. --São Paulo, 2015.228 p. : il.

Dissertação (Mestrado - Área de Concentração: Projeto, Espaço e Cultura) - FAUUSP.

Orientadora: Ana Cláudia Castilho Barone

1.Arquitetura moderna - São Paulo (SP) 2.História da arquitetura 3.Faculdade de Arquitetura e Urbanismo/USP

4. Luiz Inácio de Romeiro de Anhaia Mello (1891-1974)

5.João Batista Vilanova Artigas (1915-1985) I.Título 
À Lídia e ao Pablo 


\section{AGRADECIMENTOS}

À CAPES, pela concessão da bolsa que tornou possível a realização desta pesquisa.

À Profa. Dra. Ana Cláudia Castilho Barone, pela orientação dedicada, pelo incentivo permanente e pela confiança neste trabalho.

Ao Prof. Dr. José Tavares Correia de Lira e à Profa. Dra. Silvana Barbosa Rubino, membros de minha banca de qualificação, pelas observações pertinentes que enriqueceram o desenvolvimento da pesquisa e que procuramos, na medida do possível, incorporar na redação final da dissertação.

Aos meus pais, Lídia e Pablo, pelo apoio incondicional que sempre me deram para que eu perseguisse meus sonhos e, agora, para que eu pudesse realizar mais este projeto.

Aos meus irmãos, Paula e Rafael, pela amizade e pelas trocas que me enriquecem diariamente.

Aos funcionários da FAUUSP, cujo apoio foi fundamental para a realização da pesquisa. Especialmente, Maria Ezilda Gratieri, Luciene e Rogério, do Departamento de Projetos, Eliana e Rejane, da Biblioteca, Iliete Maria de Franco Arruda, Cláudio, do setor de informática e Magali Baroni, da Seção Acadêmica.

À Maria Luiza, do Arquivo Histórico da Escola Politécnica.

À Profa. Dra. Maria Cristina da Silva Leme, ao Prof. Dr. Rodrigo Queiroz e ao Prof. Dr. Luiz Antônio Recamán Barros, pelo apoio que ofereceram ao longo do desenvolvimento da pesquisa.

À Carolina Tomoi, pela revisão desta dissertação.

Às minhas amigas Natália Gaspar e Dora Dias, que compartilham o interesse por estudar a FAUUSP, pelas generosas conversas que tivemos durante o processo de trabalho.

Ao Kasuo Sakurai, aluno da FAUUSP da turma de 1963, que por outros caminhos muito me ensinou em nossa convivência.

Ao João Sodré, que generosamente compartilhou suas entrevistas aos antigos alunos da FAUUSP.

À equipe que trabalhou comigo na Cetesb no início deste percurso, pelo apoio, paciência e amizade. Viviane Kondratiuk, Kasuo Sakurai, Nádia Brink, Solange Miyasaki, Maria Carolina Villaça Gomes, Gizela Peralta, Regina Brito, Renata Borsói.

Aos meus amigos, pelas conversas, leituras e pela compreensão ao longo do processo. Gregory Valente, Rafael Farina, José Eduardo Gonçalves, Bruno Nogueira, Paulo Martins, Nelcili Helen Pinto, Eduardo Castanho, Rinaldo Pinho, Rubenilda Gomes da Silva, Manoel Silva, Robson Pinho, Carolina Tomoi, Nadyne Piotto, Maite Rios, Rafael de Abreu, Rafael Stucchi, Ellen Souza, Fernanda Ultremare, Orlando Vieira Francisco, entre tantos que tenho a felicidade de ter ao meu redor.

Ao Bruno, mais uma vez, por diagramar o trabalho. 


\section{RESUMO}

SIQUEIRA, R.M. A inserção da FAUUSP no campo de arquitetura e urbanismo em São Paulo: as contribuições de Anhaia Mello e Vilanova Artigas. 2015. 228 f. Dissertação (Mestrado) - Faculdade de Arquitetura e Urbanismo, Universidade de São Paulo, 2015.

Esta dissertação tem por objetivo analisar a inserção da Faculdade de Arquitetura e Urbanismo da Universidade de São Paulo, FAUUSP, no campo de arquitetura e urbanismo em São Paulo, por meio da contribuição de dois de seus principais fundadores, Luiz Inácio Romeiro de Anhaia Mello (1891-1974) e João Batista Vilanova Artigas (1915-1985). Ambos foram engenheiros arquitetos formados pela Escola Politécnica de São Paulo, embora de gerações diferentes. Em sua vida profissional, Anhaia Mello tornou-se um reconhecido urbanista, defensor da institucionalização do planejamento urbano baseado no regional planning norte-americano, opondo-se ao que chamava de "urbanismo de obras". Artigas, seu aluno e assistente, tornou-se, posteriormente, um dos mais respeitados arquitetos ligados ao Movimento Moderno em São Paulo. Pretende-se verificar como as diferenças e convergências de seus pensamentos, vinculados a matrizes intelectuais distintas, interferiram sobre a configuração da nova instituição de ensino, repercutindo sobre o debate mais amplo de consolidação do campo de arquitetura e urbanismo como esfera de atuação profissional em São Paulo. Para tal, recorreu-se a vasta consulta bibliográfica assim como análises de documentos do período estudado, o qual tem por marcos os anos de 1948, data de fundação da FAUUSP, e 1962, quando foi implementada uma reforma de ensino que consolidou a ideia de um único campo em que as escalas do objeto, do edifício e da cidade estavam submetidas à atividade de projeto. Nos anos 1940, fatores internos e externos à universidade levaram à demanda pela criação de uma escola de arquitetura independente da Escola Politécnica, com a consequente extinção do curso de engenheiros arquitetos lá ministrado desde 1894. Anhaia Mello, docente catedrático da escola desde 1926, foi designado para coordenar a criação dessa faculdade e convidou Artigas a participar desse processo. Apesar de importantes divergências no pensamento desses profissionais, seu encontro na FAUUSP não deixou transparecer um debate de ideias ou uma exposição de diferenças, sugerindo a continuidade entre arquitetura e urbanismo. A hipótese que defendemos é que, apesar das diferenças de perspectiva que envolviam as duas disciplinas, a reunião entre arquitetura e urbanismo em um mesmo campo na FAUUSP foi estratégica para ambas, visando a obtenção de autonomia face à engenharia e à Escola Politécnica, bem como a consolidação de certos princípios, de modo a favorecer determinadas visões tanto na arquitetura como no urbanismo. Desse modo, a formação de um único campo institucional na nova escola revelou na verdade uma arena de embates de múltiplos interesses, nem sempre convergentes para os objetivos de uma gama de atividades profissionais bastante diversas entre si.

Palavras-Chave: 1. Fundação da FAUUSP; 2. Arquitetura Moderna em São Paulo; 3. Luiz Inácio Romeiro de Anhaia Mello (1891-1974); 4.João Batista Vilanova Artigas (1915-1985); 5. Regulamentação da profissão de arquiteto e urbanista. 


\section{ABSTRACT}

SIQUEIRA, R.M. The insertion of FAUUSP in the field of architecture and urbanism in São Paulo: the contributions of Anhaia Mello and Vilanova Artigas. 2015. 228 f. Dissertação (Mestrado) - Faculdade de Arquitetura e Urbanismo, Universidade de São Paulo, 2015.

This study aims to analyse the insertion of the Architecture and Urban Planning School in the University of São Paulo, FAUUSP, in the field of architecture and urban planning in São Paulo, through the contribution of two of its main founders, Luiz Inácio Romeiro de Anhaia Mello (1891-1974) and João Batista Vilanova Artigas (1915-1985). Both were architect engineers from de Polytechnic School of São Paulo, although they belonged to different generations. In his professional life, Anhaia Mello became an acknowledged urban planner, defending the institutionalization of this policy inspired on the north-american regional planning. Artigas was Anhaia Mello's student and assistant and later became one of the most respected architects in the Modern Movement in São Paulo. It is intended to verify how the differences and convergences of their thoughts, linked to distinct intellectual references, interfered in the configuration of the new teaching institution, reflecting on the larger debate on the field of architecture and urban planning's consolidation. To do so it was resorted to a vast bibliographical consultation and also to document analysis from the studied period which has as milestones the years of 1948, year of the establishment of FAUUSP, and 1962, when an education reform was implemented as to consolidate the idea of one field where the scales of the object, building and city were subordinated to the project activity. Around 1940, internal and external factors to the university lead to a demand for the creation of an architecture school independent from the Polytechnic School, with the correspondent extinction of the course of architect engineers that existed since 1894. Anhaia Mello, one of the main teachers of the Polytechnic School since 1926, was designated to coordinate the founding of the new school and invited Artigas to participate on this process. Despite the different ideas of these two professionals, their meeting at FAUUSP did not expose a debate or displayed the divergences, suggesting a continuity among architecture and urbanism. The intended hypothesis to defend is that, despite the different perspectives around both disciplines, the reunion of architecture and urbanism at FAUUSP was part of a strategy for both fields willing to obtain autonomy from engineering and the Polytechnic School and the consolidation of certain principles, in order to benefit specific visions of architecture and urbanism. Therefore, the constitution of only one institutional field at the new school actually revealed an arena of multiple interests, not always convergent to the goals of a range of professional activities very different from each other.

Key-words: 1. Founding of FAUUSP; 2. Modern Architecture in São Paulo; 3; Luiz Ignácio Romeiro de Anhaia Mello (1891-1974); 4. João Batista Vilanova Artigas (1915-1985); 5; Architect and urban planner's regulation. 


\section{LISTA DE ABREVIATURAS E SIGLAS}

CBA - Congresso Brasileiro de Arquitetos

CECAP - Caixa Estadual de Casas Para o Povo

CONFEA - Conselho Federal de Engenharia, Arquitetura e Agrimensura

CREA - Conselho Regional de Engenharia, Arquitetura e Agrimensura

DAFAM - Diretório Acadêmico da Faculdade de Arquitetura do Mackenzie

DOSP - Diário Oficial do Estado de São Paulo

DOU - Diário Oficial da União

ENBA - Escola Nacional de Belas Artes

FAUUSP - Faculdade de Arquitetura e Urbanismo da Universidade de São Paulo

FAUM - Faculdade de Arquitetura e Urbanismo do Mackenzie

FFCL - Faculdade de Filosofia, Ciências e Letras da Universidade de São Paulo

FNA - Faculdade Nacional de Arquitetura da Universidade do Brasil

Gfau - Grêmio estudantil da FAUUSP

IAB - Instituto de Arquitetos do Brasil

IE - Instituto de Engenharia

IPA - Instituto Paulista de Arquitetos

PRP - Partido Republicano Paulista

SAC - Sociedade Amigos da Cidade

SAL - Sociedade Amigos de Londrina

UIA - União Internacional de Arquitetos 


\section{SUMÁRIO}

Introdução

Capítulo 1 - A formação do campo profissional de arquitetura e urbanismo em São Paulo e a construção da relação entre arquitetura e urbanismo na FAUUSP 27

1. A institucionalização do campo de arquitetura e urbanismo 29 em São Paulo

2. A consolidação da FAUUSP como uma escola de arquitetura 35 moderna

2.1. Arquitetura como Composição $\quad 35$

2.2. Mudanças na estrutura curricular da FAUUSP $\quad 38$

2.2.1. I948-I962: Consolidação Institucional $\quad 38$

2.2.2 Os debates que antecederam a reforma $\quad 40$ curricular da FAUUSP de ig62

3. Mudanças no corpo docente 49

Capítulo 2 - O Papel de Anhaia Mello na criação da FAUUSP 55

1. A inserção de Anhaia Mello na Escola Politécnica $\quad 57$

2. As posições urbanísticas de Anhaia Mello $\quad 67$

3. Anhaia Mello e a fundação da FAUUSP $\quad 76$

4. O Centro de Pesquisas e Estudos Urbanísticos 79

Capítulo 3 - Artigas e a formação do campo de arquitetura em São Paulo 85

1. A Formação (I932-1939)

2. Atuação Profissional (I940-1962) 94

2.1. O assistente de Anhaia Mello 94

2.2. A visão de Artigas sobre a FAUUSP 96

$\begin{array}{lc}\text { 2.3. Atuação no IAB-SP } & 102\end{array}$

2.3.1. Os Congressos Brasileiros de Arquitetos 103

2.3.2. A luta do IAB pela regulamentação 106

profissional

3. A "Função Social da Arquitetura" e a ideia de plano

dela decorrente

Capítulo 4 - A FAUUSP e o "plano" como a interface entre arquitetura e urbanismo

1.Mudanças no ensino de projeto e planejamento da FAUUSP 119

1.1. Composição de Arquitetura 119

1.1.1. Cadeira $n^{\circ}$ I6. Composição de Arquitetura.

Pequenas Composições - Partes I e II ( $\left(^{\circ}\right.$ e $2^{\circ}$ anos). 
1.1.2. Cadeira $n^{\circ}$ I7. Composição de Arquitetura.

Pequenas Composições - Parte II2 ( $3^{\circ}$ ano).

1.1.3. Cadeira $n^{\circ}$ I8. Composição de Arquitetura.

Grandes Composições - Parte I (4 $4^{\circ}$ ano).

1.1.4. Cadeira ${ }^{\circ}$ I9. Composição de Arquitetura.

Grandes Composições - Parte II ( $5^{\circ}$ ano).

1.1.5. Considerações sobre o ensino de

Composição de Arquitetura na FAUUSP

1.2. Do urbanismo ao planejamento

1.2.1. Cadeira de Urbanismo (I953-I962)

129

1.2.2. Cadeiras de Planejamento

(a partir de i963)

1.2.3. Considerações sobre as disciplinas

de urbanismo e planejamento

2. O "plano" como a interface entre arquitetura e urbanismo

2.1. Antecedentes: o urbanismo no âmbito do

Movimento Moderno em Arquitetura

\begin{tabular}{ll} 
2.1.1. La Cité Industrielle, Tony Garnier & 136 \\
\hline 2.1.2. Le Corbusier & 142
\end{tabular}

3. Anhaia Mello e o plano regional de São Paulo

3.1. Uma análise de "O Plano Regional de São Paulo:

uma contribuição da universidade para o estudo de um código de ocupação lícita do solo (I954)"

Referências Bibliográficas

4. A participação de Artigas no planejamento municipal

4.1. Londrina (I948-I955), um negócio em família 163

$\begin{array}{ll}\text { 4.2. Brasília } & 165\end{array}$

5. Considerações sobre a continuidade e divergência entre os 175 pensamentos de Artigas e Anhaia Mello

Apêndices

Apêndice A - mudanças na estrutura curricular da fau-usp e corpo docente

responsável

Apêndice B - quadro dos professores de composição (I948-I962)

Apêndice C - renovação do corpo docente da FAUUSP (I948-Ig62)

Apêndice D - professores de composição

Anexos

Anexo a- estrutura curricular da FAUUSP (1948/1955/1962/1963).

Anexo b - currículo pleno da FAUUSP proposto em I962. 


\section{INTRODUÇÃO}


Neste trabalho, analisamos a inserção da Faculdade de Arquitetura e Urbanismo da Universidade de São Paulo, FAUUSP, no campo de arquitetura e urbanismo em São Paulo, por meio da contribuição de dois de seus principais fundadores, Luiz Ignácio Romeiro de Anhaia Mello (1891-1974) e João Batista Vilanova Artigas (1915-1985). A FAUUSP foi criada em 1948, desvinculando-se da Escola Politécnica, onde até então era ministrado o curso de engenheiros arquitetos. Tratava-se, portanto, de um passo importante para a autonomia dos campos profissionais de arquitetura e de urbanismo face à engenharia. Procuraremos demonstrar que a consolidação dessa autonomia foi fundamental para a afirmação da arquitetura moderna como corrente hegemônica em São Paulo, bem como para constituir um campo de urbanismo baseado em princípios normativos e na ideia de plano, rompendo com o urbanismo de projetos desenvolvido na Escola Politécnica e na engenharia municipal na primeira metade do século XX. Por meio da atuação dos dois profissionais nesse processo, poderemos observar que a nova faculdade inseriu-se em um âmbito de luta pela realização de dois projetos distintos, um ligado ao urbanismo, outro à arquitetura moderna. Portanto, a despeito da reunião institucional dessas duas disciplinas em uma única escola e apesar dos diversos pontos de tangência entre elas, não se tratou de formar um campo único, mas sim, paralelamente, de fortalecer a ambos, alimentados, inclusive, por matrizes intelectuais distintas.

Para compreender como se deu a institucionalização da arquitetura e do urbanismo na FAUUSP, adotamos o período de 1948, ano de fundação, até 1962, quando foi feita uma reforma de ensino em que se consolidou a ideia de um único campo englobando não apenas a arquitetura e o urbanismo, mas também o desenho industrial. Entre 1948 e 1962, as aulas "práticas" de arquitetura eram ministradas nas cadeiras de composição de arquitetura, herança carregada do ensino politécnico. Foi apenas na reforma de 1962 que essa terminologia foi alterada, dando lugar às disciplinas de projeto. Assim, optamos por estudar o período de "consolidação institucional" da faculdade, que corresponde também ao momento em que Anhaia Mello e Artigas coexistiram naquele espaço, facilitando a explicitação de alinhamentos e divergências no âmbito docente.

$* * *$

Anhaia Mello e Artigas foram, ambos, engenheiros arquitetos formados pela Escola Politécnica e trabalharam conjuntamente na fundação da FAUUSP. Pode-se considerar a relação entre eles como a de um mestre e um discípulo. Todavia, há que se ressaltar as importantes diferenças entre os profissionais, ainda que, analisando-os no presente, essas diferenças possam parecer mais claras que seus alinhamentos.

Anhaia Mello formou-se com distinção em 1913, vinte anos após a criação da Escola Politécnica. Tratava-se de um período que Ficher caracterizou como uma fase de "consolidação do mercado de trabalho" (2005, p. 28). Naquele momento, a própria engenharia encontrava-se em processo de consolidação do campo profissional. Os engenheiros buscavam afirmar-se como classe da elite dirigente de São Paulo, em disputa com os campos já consagrados, principalmente do direito, mas também da medicina, sob a égide da cientificidade e da técnica. A profissão ainda não havia sido regulamentada e os engenheiros diplomados disputavam espaço com construtores "práticos”. A Escola Politécnica era dirigida por seu fundador, Antônio Francisco de Paula Souza (1843-1917) e o professor mais influente 
do curso de engenheiros arquitetos era Francisco de Paula Ramos de Azevedo (1851-1928). Esse docente foi também o mais importante arquiteto da Primeira República em São Paulo, não apenas por ser responsável pela maior parte dos edifícios públicos produzidos no período, como por ter constituído um conjunto de empresas que abarcava todo o setor da construção civil e de produção da cidade.

Ramos de Azevedo, que tinha estreita amizade com a família de Anhaia Mello, abriu muitas portas ao seu aluno, seja ao contratá-lo para trabalhar e dirigir suas empresas quando de sua formatura, como por tê-lo em alta consideração quando o pupilo ingressou para a docência na Escola Politécnica, em 1918, como lente substituto. Em 1926, Anhaia Mello foi promovido a professor catedrático, lecionando na cadeira de "Estética, Composição Geral e Urbanismo - $1^{\mathrm{a}}$ e $2^{\mathrm{a}}$ Partes". Foi um dos docentes mais importantes do curso de engenheiros arquitetos da Poli, ao dirigir uma das poucas cadeiras voltadas exclusivamente para os estudantes daquele curso. Nos anos 1940, foi designado pela Congregação da escola para coordenar os trabalhos de criação da faculdade de arquitetura da Universidade de São Paulo. Dessa nova escola foi seu primeiro diretor, lecionando na cadeira de Urbanismo até sua aposentadoria em 1961. Desde o fim da década de 1920, Anhaia Mello consagrou-se como uma das principais autoridades em matéria de urbanismo, divulgando as ideias do regional planning norte-americano (FELDMAN, 2005). Sua posição, todavia, contrastava com a prática urbanística que se desenvolvia na cidade de São Paulo, sobretudo a partir do setor de obras municipais, vinculada à implantação de infraestruturas e priorizando o setor viário (ARASAWA, 1999). Diante da oportunidade de fundar uma nova escola, separada da engenharia, Anhaia Mello trabalhou no sentido de trazer para essa faculdade, além da graduação em arquitetura, o ensino de urbanismo, a princípio na forma de uma pós-graduação voltada para arquitetos e engenheiros civis. Essa proposta demarcava a "ciência" do urbanismo como uma atividade de especialistas, superior, portanto, à dos bacharéis, fossem de engenharia como de arquitetura. Muito embora não tenha se concretizado a instalação dessa pós-graduação durante o período em que o urbanista lecionou na FAUUSP, ele criou o Centro de Pesquisa e Estudos Urbanísticos, CPEU, que a partir de 1957 se tornou um lugar de autoridade em que se posicionava sobre os assuntos de urbanismo e onde, inclusive, colocou em prática suas ideias na realização de planos diretores.

Artigas formou-se em 1937, tendo como docentes mais influentes, em sua própria visão, Alexandre Albuquerque (1880-1940), Francisco Prestes Maia (1896-1965) e, principalmente, Anhaia Mello. Esse corpo docente, egresso da própria escola anos antes, indicava que aquela instituição se encontrava em uma fase já consolidada. A situação da Escola Politécnica havia se alterado substancialmente com relação ao período discente de Anhaia Mello e, igualmente, a situação político-econômica nacional, com o fim da Primeira República, o advento da revolução constitucionalista, em que a Escola Politécnica envolveu-se ativamente e, a despeito dela, da ascensão de Getúlio Vargas à presidência. Inaugurou-se o período em que o Brasil haveria de se tornar um país urbano, industrializado, moderno. Desde 1934, a escola havia sido incorporada pela recém-criada Universidade de São Paulo. A primeira regulamentação federal das profissões de engenheiros, arquitetos e agrônomos foi promulgada em 1933. Essa lei acabou por favorecer a atuação dos engenheiros, de modo que os arquitetos tendiam a ser associados a desenhistas, projetistas de fachadas, etc. A partir de então, iniciou-se uma longa trajetória de luta por diferenciação interna entre essas profissões, da qual Artigas se tornou um ativo expoente. Diferentemente do mestre, que 
construiu sua carreira profissional com base no urbanismo, foi no âmbito da arquitetura moderna que Artigas teve sua atuação mais relevante. Além de seus projetos, que o notabilizaram como grande arquiteto, envolveu-se no embate político pela institucionalização profissional. Ainda em 1948, passou a compor o conselho da administração do Museu de Arte Moderna de São Paulo, MAM, recém-criado pelo industrial Francisco Matarazzo Sobrinho e pela aristocrata paulista Yolanda Penteado. Esse museu teve um importante papel agregador dos profissionais de arquitetura e de urbanismo. Seu envolvimento com o meio artístico, contudo, vinha dos anos de estudo na Escola Politécnica, quando participou da Família Artística Paulista.

Em 1943, participou da criação do departamento paulista do Instituto de Arquitetos do Brasil, IAB-SP, que atuou fortemente em prol dos interesses profissionais, mediado pela defesa da arquitetura moderna. No IAB-SP, colaborou com a organização do I Congresso Brasileiro de Arquitetos, CBA, em que esses interesses passaram a ser discutidos pela comunidade de arquitetos. Essa luta institucional foi, desde então, acompanhada pela luta por afirmação da arquitetura moderna e dos princípios a ela vinculados, especialmente a função social da arquitetura, a industrialização da construção e a noção de arquitetura como síntese das artes. Nesse contexto, esses arquitetos passaram a reivindicar para si atribuições antes destinadas aos engenheiros, na crença de que sua "visão mais completa da vida humana" (MORSE, 1954, p. 304) substituiria a visão tecnocrática que dominava esses aspectos. Assim, passaram a defender, dentre outros, o urbanismo e a casa popular como responsabilidades do âmbito da arquitetura. Os encontros promovidos pelo IAB consistiam em um momento de debate e de convencimento acerca da importância de definir o papel do arquiteto e a atribuição profissional, propondo revisões na lei de instituição do Conselho Federal de Engenharia, Arquitetura e Agrimensura, CONFEA, e dos Conselhos Regionais de Engenharia, Arquitetura e Agrimensura, CREA. Defendia-se a industrialização da construção e discutia-se as tarefas de incumbência de arquitetos e como estes poderiam desempenhá-las. Dentre as funções reivindicadas por arquitetos, chamamos a atenção para a habitação social e o equipamento público como elementos de interface entre os campos de arquitetura e urbanismo, mediados pelo plano. Vale observar que a questão da casa popular ganhou centralidade desde os anos 1930, tornando-se ela também objeto de disputa entre engenheiros e arquitetos, afinal vencida pelos últimos. Nota-se que a institucionalização da arquitetura moderna em São Paulo, como mostra a atuação do IAB, passava em grande medida pela questão da atribuição profissional em disputa com a engenharia.

Em 1940, Artigas foi convidado a tornar-se professor assistente de Anhaia Mello na cadeira de "Estética, Composição Geral e Urbanismo - $1^{\text {a }}$ e $2^{\text {a }}$ Partes", cargo que foi de fundamental importância para sua trajetória e no qual permaneceu por toda aquela década. Assim, diante da perspectiva de criação da nova faculdade, Artigas foi um dos profissionais convidados por Anhaia Mello a colaborar. O jovem arquiteto realizou, inclusive, uma viagem entre 1946 e 1947 aos Estados Unidos com o apoio do catedrático e autorizado pela Escola Politécnica, sob a justificativa de estudar o sistema de ensino daquele país, com vistas à criação da FAUUSP. Foi Artigas quem elaborou o projeto de reforma da Casa Penteado, doada à USP para abrigar a faculdade e, catorze anos depois, foi o autor do premiado projeto do edifício da FAUUSP na Cidade Universitária. Foi também o primeiro docente responsável pelas aulas de Composição de Arquitetura da faculdade.

Embora ainda pouco estudado, o vínculo entre Anhaia Mello e Artigas revelou-se 
um rico objeto de análise do modo como se estruturou a FAUUSP desde sua fundação e como essa instituição inseriu-se no campo profissional de arquitetura e urbanismo, que naquele momento se fortalecia. Apesar das claras diferenças de posição de ambos - motivadas por diferenças de geração, de origem social, de relações políticas, de objetos de interesse, dentre muitas outras - essa aliança foi fundamental para viabilizar a estruturação da FAUUSP do modo como se deu. Ainda assim, suas perspectivas distintas deveriam, a princípio, ter suscitado um debate de ideias ou uma exposição de diferenças, que até o momento não foram trazidos à tona.

Identificamos uma aproximação de Anhaia Mello e dos arquitetos ligados ao IAB no período de fundação da FAUUSP. Em um contexto em que profissionais que não fizessem arquitetura moderna eram repudiados pelo instituto (DEDECCA, 2012, p. 56), Anhaia Mello chegou a compor sua diretoria em duas gestões - não por coincidência, entre 1947 e 1949. Por outro lado, como veremos, o urbanista esteve longe de endossar todos os interesses desses arquitetos, confrontando-os quando suas ideias entraram em disputa.

Ao longo da pesquisa, procuraremos defender uma hipótese explicativa do modo específico como se construiu a aliança entre arquitetura e urbanismo na FAUUSP. Tratava-se de conquistar a autonomia face à engenharia para, por um lado, consolidar a arquitetura moderna em São Paulo como movimento hegemônico, legítimo e distinto daquele articulado no Rio de Janeiro desde os anos 1930, e por outro, constituir um campo de urbanismo autônomo, com base nas ideias defendidas por Anhaia Mello - um urbanismo abstrato, baseado na regulamentação urbanística, mediante aprovação de leis, em oposição ao urbanismo de projeto que se desenvolvia a partir da Escola Politécnica, baseado no desenho da cidade por meio da dotação de infraestrutura urbana. A criação da FAUUSP, separada da Escola Politécnica, apresentava-se como um caminho promissor para alcançar esses dois objetivos independentes entre si. Havia, portanto, dois campos de conflito e não a formação de um único campo de continuidade entre arquitetura e urbanismo.

No contexto da especialização profissional que se vivia naquele momento, havia uma pressão interna à própria USP para a fundação da nova faculdade. Mas havia também uma pressão externa referente ao fortalecimento institucional da arquitetura, no sentido da afirmação da arquitetura moderna em São Paulo, a partir da década de 1940. Isso pode ser observado em diversas esferas, como a das instituições culturais, ou da criação de escritórios profissionais que passaram a limitar-se à realização de projetos, não mais se dedicando à construção. Entretanto, a criação do IAB-SP, em 1943, teve especial importância, ao reunir os profissionais interessados na afirmação da arquitetura moderna em São Paulo, passando a articular as mobilizações, as reivindicações e os debates com esse objetivo e repelindo os profissionais que não se alinhassem a essa perspectiva.

Diante do contexto favorável que incluía o interesse da universidade em instituir uma nova faculdade de arquitetura independente da engenharia e o fortalecimento institucional da arquitetura moderna durante os anos 1940, Anhaia Mello criou, junto com a faculdade de arquitetura que fora incumbido de fundar, uma faculdade de urbanismo, que, favorecida pelo sucesso que a arquitetura vinha experimentando naquele momento, nascia fortalecida. A emancipação da arquitetura se dava no âmbito das instituições profissionais, tais como o IAB, que se encontrava em franca consolidação, sobretudo a partir da luta por delimitar as atribuições que distinguiriam os arquitetos dos engenheiros. A emancipação do urbanismo, por sua vez, era de ordem política, dependendo de organizações adminis- 
trativas internas ao órgão público, como a própria trajetória de Anhaia Mello revelou (FELDMAN, 2005). Aproveitando que o campo de arquitetura se fortalecia por meio do IAB e o interesse em criar uma faculdade de arquitetura na USP, Anhaia Mello criou uma faculdade de urbanismo, em que constituiu um lugar de autoridade para defender e por em prática suas ideias. Nesse processo, Anhaia Mello convocou seu assistente Artigas para fundar a faculdade de arquitetura, forjando-o como uma eminente liderança. Essa liderança acabou por ter maior projeção que seu próprio mestre. Hoje, na FAUUSP, Anhaia Mello parece um pouco esquecido, ao passo que Artigas é uma referência constante, por vezes de forma acrítica. Acreditamos que dentre outras razões, isso possa ser explicado pela reforma de ensino realizada em 1962, em seguida à aposentadoria de Anhaia Mello, que submeteu todas as atividades didáticas ao projeto. Além disso, também contribui a existência de diferenças fundamentais entre os campos de arquitetura e de urbanismo. Podemos considerar que enquanto a arquitetura está no âmbito da mercadoria e da obra de arte, o urbanismo é uma atividade política, que envolve disputas e negociações, sujeita a fracassos muito mais regularmente.

Apesar de chamarmos a atenção para a constituição de dois campos distintos na FAUUSP, não se pode negligenciar que tanto o urbanismo, como disciplina, quanto a arquitetura moderna, como movimento estético e linguagem, estão inseridos no contexto cultural da modernidade. Portanto, havia um objetivo em comum maior, de consolidar uma instituição que teria por propósito lançar o Brasil na rota da modernidade, contribuindo para a criação de um projeto de futuro para o país, através dos conteúdos produzidos por essa instituição. Havia, assim, um sentido na aliança da ciência do urbanismo, nascendo moderna, em fins do século XIX, e da arquitetura, rompendo com o ecletismo para tornar-se moderna, se considerarmos o pressuposto da modernidade como denominador comum. Dessa forma, Anhaia Mello aderiu ao Movimento Moderno em Arquitetura em São Paulo, não porque desejasse tornar-se arquiteto moderno, mas em defesa da causa moderna, visto que essa arquitetura representava a modernidade que ele queria sobrelevar.

Finalmente, devemos destacar a importância da formação de profissionais para a consolidação do campo de arquitetura naquele momento. Essa questão, reiteradamente discutida nos congressos de arquitetos realizados no período, dá a medida da dimensão que tinha a criação de uma instituição de ensino de orientação moderna ligada à Universidade de São Paulo. Por esse motivo, optamos por analisar os elementos da formação, através, dentre outros, da análise das disciplinas ministradas e de seu corpo docente.

$* * *$

Observando os debates travados no âmbito dos congressos promovidos pelo IAB desde 1945, reconhecemos a intenção de relacionar a atuação do arquiteto com a Função Social da Arquitetura, e neste âmbito, o esforço em demarcar as atribuições específicas do arquiteto, dentre as quais, o urbanismo. Nessas teses, recorrentemente o plano aparecia como o instrumento que faria a interface entre arquitetura e urbanismo, ideia que foi perpetuada na FAUUSP, como veremos no desenvolvimento deste trabalho. Procuraremos demonstrar que o "plano" foi empregado como o elemento de interface entre arquitetura e urbanismo naquele momento, porém unicamente até o ponto em que atendia aos objetivos comuns aos dois campos. As importantes diferenças conceituais referentes ao instrumento 
para um e outro campos não foram debatidas, pois isso poderia inviabilizar a realização do objetivo em comum aos dois naquele momento: autonomizar-se face à engenharia.

Logo no I CBA, o planejamento regional teve destaque como o instrumento capaz de dar respostas aos problemas de organização da produção, circulação e distribuição de riquezas, para o planejamento da localização das atividades de produção e do sistema de transportes. Com isso, pretendia-se planejar a organização das coletividades, tendo em vista o zoneamento e a fixação do homem em núcleos organizados, evitando a dispersão pelo território. Finalmente, defendia-se que, visando impedir o agravamento das condições de vida nos centros populosos, dever-se-ia dar preferência à fixação do homem nos núcleos rurais e industriais ao invés de ocuparem-se as periferias dos núcleos urbanos ${ }^{1}$.

Devemos assinalar que conceitos como plano, planejamento regional, zoneamento, dentre outros, foram difundidos entre arquitetos e engenheiros filiados às mais distintas correntes de pensamento durante o século XX e, portanto, cabiam nas teses de Anhaia Mello e nas dos arquitetos modernos paulistas. Entretanto, apesar de uma suposta sintonia com o urbanismo de Anhaia Mello, a ideia de plano expressa pelos arquitetos paulistas remetia mais diretamente ao urbanismo de Le Corbusier (1887-1965), que por sua vez, tinha por uma de suas principais referências a Cité Industrielle de Tony Garnier (1869-1948), pioneira no uso do zoneamento. Já Anhaia Mello, muito embora se referisse em seus textos a uma profusão de autores muito distintos entre si, tinha por principal referência o regional planning norte-americano, que tinha outros pressupostos. Como procuraremos demonstrar neste trabalho, se para aqueles o plano, imbuído da ideia de previsão, caracterizava-se como o desenho da cidade, assinalando a melhor localização dos equipamentos a serem projetados, para Anhaia Mello, tratava-se de regulamentar o uso e ocupação da cidade visando proteger residências de vizinhos inadequados, bem como controlar o crescimento da cidade. Deve-se, contudo, assinalar que as duas visões de plano eram concorrentes, porém não excludentes. Isso permitiu sua coexistência durante muito tempo sem que se deflagrassem os debates sobre suas origens e significados distintos.

A adoção do plano como interface entre arquitetura e urbanismo no contexto de fundação da FAUUSP revela a existência de interesses em jogo. Indica que a aliança, naquele momento, era profícua para contrapor-se à ideia de urbanismo como projeto e assim, separar-se da engenharia e garantir a constituição de um campo de urbanismo autônomo e, ao mesmo tempo, fortalecer a arquitetura moderna. Adotando esse pressuposto - do plano como interface entre os dois campos - sem, contudo, nomear o que se designava como plano, assegurava-se a viabilidade daquela aliança, pois tornava-se elemento de unidade. A definição do que viesse a ser o plano para os atores interessados inviabilizá-la-ia, na medida em que a própria ideia de plano passaria a ser objeto de disputa. Na pesquisa, buscaremos evidenciar a estratégia de construção dessa união mediante a adoção de um vocabulário em comum através do silenciamento sobre o seu sentido, bem como procuraremos expor as diferenças conceituais a partir das matrizes de referência que os informavam. Por um lado, os arquitetos atinham-se, sobretudo, à vertente corbusiana, o que tinha por consequência, dentre outros, a defesa da aliança com o Estado, o comissionamento do arquiteto e o seu papel prioritário na realização do trabalho de urbanismo. Por outro, o regional planning americano entendia o plano de forma abstrata, legalista, regulamentadora e propunha a reformulação da estrutura administrativa para sua realização. Como veremos, nos momentos em que identificamos uma efetiva tentativa de aproximação entre os dois campos na FAUUSP, essa se mostrou ineficaz, o que pode ser explicado pelo fato de remeterem a significados distintos de plano e de urbanismo, que não interessavam ser discutidos. 
Assim, a união dos interesses ligados à arquitetura moderna e ao urbanismo na FAUUSP consistiu na adoção de uma estratégia em comum a dois grupos distintos que pretendiam ganhar autonomia face ao campo da engenharia com vistas à constituição de um campo de urbanismo autônomo que seguia uma determinada orientação, por um lado, e, por outro, à afirmação da arquitetura moderna como linguagem hegemônica em São Paulo. Portanto, não se tratou necessariamente da concepção de um único campo que envolvesse os dois saberes, de arquitetura e urbanismo, mas da aliança entre os dois saberes como forma de se separarem de uma terceira disciplina que os impedia de atingir seus objetivos.

Este trabalho contou com uma rica produção bibliográfica como ponto de partida. Existe uma bibliografia recente que trata da formação do campo profissional de arquitetura em São Paulo e no Brasil que nos foi significativamente útil e inspiradora. Dentre esses trabalhos, destacamos os de Silva (2010), Rabelo (2011), que relacionaram a formação do campo profissional à modernização das cidades, respectivamente, de São Paulo e do Rio de Janeiro, evidenciando as disputas vividas nesse processo, e Dedecca (2012), que colaborou para o aceno de um importante caminho assumido nesta pesquisa, levando-nos a observar a institucionalização do campo profissional através do IAB. Dentre os trabalhos sobre a FAUUSP, Sodré (2010), por adotar o mesmo recorte temporal desta pesquisa e por seu trabalho exaustivo de entrevista aos ex-alunos da faculdade foi-nos de grande importância.

Dentre os arquitetos paulistas, Artigas é certamente um dos mais, senão o mais estudado. Existem trabalhos minuciosos sobre a sua trajetória, que consultam e analisam uma extensa relação de fontes documentais e que nos foram de grande utilidade, como os de Thomaz (1997; 2005). Outros, como Buzzar (1996) nos ajudaram a compreender a relação da produção de arquitetura com a sua inserção política no Partido Comunista Brasileiro, PCB. Todavia, no que se refere à problematização da sua trajetória e de sua obra, foi muito inspiradora a pesquisa de Gabriel (2003), cuja leitura, inclusive, apontou-nos caminhos decisivos para a compreensão da ideia do "plano" como a interface entre arquitetura e urbanismo.

É notável a discrepância entre o volume da produção de pesquisas sobre Artigas e sobre Anhaia Mello. Desde o princípio, isso se apresentou como um indicador de que, a despeito do papel fundamental de Anhaia Mello, como mestre, condutor da aliança com os arquitetos modernos e fundador da FAUUSP, sua importância acabou por ficar um pouco à sombra da do discípulo que ele próprio ajudou a projetar. Os principais trabalhos com os quais pudemos contar foram realizados na década de 1990. Trata-se da tese de doutorado de Meyer (1991) em que as ideias de Anhaia Mello são contrapostas às de Prestes Maia, da tese de doutorado de Feldman (1996), em que a autora revela como as ideias do urbanista foram incorporadas pela administração municipal de São Paulo e a dissertação de mestrado de Arasawa (1999), que debateu as estratégias às quais Anhaia Mello recorreu para fazer valer sua teoria, que intitulou de "árvore do urbanismo". Mais recentemente, o urbanista voltou a despertar interesse de pesquisadores como Bresciani, que vem desenvolvendo uma pesquisa voltada para o aprofundamento de suas posições teóricas e que orientou a dissertação de mestrado de Timóteo (2007) acerca da proposta de recreio ativo e organizado do urbanista. Para a realização desta pesquisa, consultamos a documentação das pastas funcionais de Artigas e de Anhaia Mello na Escola Politécnica, programas de disciplinas e outros documen- 
tos relativos à FAUUSP, assim como os registros dos Congressos Brasileiros de Arquitetos realizados pelo IAB desde 1945.

A partir de um levantamento de toda a documentação que pudemos encontrar sobre a FAUUSP nesse período, que apesar de tudo é pouco abundante - entre programas de disciplinas, relatórios, registros de fóruns de debates, seminários de ensino etc. - procuramos identificar quais eram as discussões que se realizavam naqueles anos e, na medida do possível, quem foram os agentes envolvidos. Isso nos levou a constatar que houve, no campo da arquitetura, uma pluralidade relativamente grande de atores que, apesar de concepções nem sempre coincidentes, procuraram afirmar a arquitetura moderna dentro da instituição e efetivar reformas que viabilizassem esse projeto. Por outro lado, no campo do urbanismo, Anhaia Mello foi praticamente a voz única da faculdade até sua aposentadoria, em 1961.

O levantamento do corpo docente a partir do programa das disciplinas de composição motivou uma busca por trabalhos acadêmicos sobre esses arquitetos. Apesar das informações levantadas nas fontes primárias e secundárias consultadas indicarem um papel muito relevante desses profissionais em diversos aspectos da história da arquitetura e do urbanismo em São Paulo e no Brasil, observou-se que é muito escassa a produção crítica a seu respeito. Dentre eles, Hélio de Queiroz Duarte, Abelardo de Souza, Zenon Lotufo, Roberto Cerqueira César, Carlos Millán e mesmo de Rino Levi. Além deles outros são ainda menos conhecidos, como José Vicente Vicari, a despeito de sua atividade junto aos Congressos Brasileiros de Arquitetos, CBA, conforme pudemos constatar ${ }^{2}$. Em contrapartida, sobre Artigas, identificamos trinta pesquisas acadêmicas no banco de teses da Capes, das quais ao menos dezoito foram realizadas na FAUUSP. Se o número absoluto de pesquisas produzidas não pode ser considerado exageradamente elevado, em contraste com as pesquisas sobre os demais arquitetos ligados à FAUUSP e ao campo de arquitetura e urbanismo em São Paulo é notável. Isso certamente reflete uma opção historiográfica que tem consequências sobre a forma como a história da arquitetura e do urbanismo paulistas é interpretada atualmente e indica a premente necessidade de se problematizá-la a partir de outras referências. Procuramos permanentemente relacionar os processos vividos dentro da faculdade com acontecimentos relativos ao campo profissional em São Paulo, contando para isso, principalmente, com a documentação relativa aos CBA e outras publicações do Instituto de Arquitetos do Brasil, IAB, além de publicações em revistas especializadas.

Através da consulta às Atas de Congregação da Escola Politécnica, das Pastas Funcionais de Anhaia Mello, na Escola Politécnica, e de Artigas, na Escola Politécnica e na FAUUSP, acrescidos de outros documentos na biblioteca da FAUUSP, procuramos compreender a atuação desses arquitetos no meio universitário e no meio profissional. Isso foi confrontado com suas posições manifestas em seus textos e discursos.

No que se refere ao acesso às fontes, é notável a maior dificuldade que encontramos para acessar a documentação relativa aos docentes e à própria escola na FAUUSP em relação aos arquivos institucionais da Escola Politécnica. Essa dificuldade se deve, certamente, a uma ampla ordem de fatores. Dentre eles, diferentemente da tradicional Escola

2 No Apêndice D apresentamos dados biográficos dos arquitetos responsáveis pelas disciplinas de composição de arquitetura da FAUUSP. 
Politécnica, que já era uma instituição consagrada antes mesmo da criação da Universidade de São Paulo, a FAUUSP esteve por muito tempo ligada à escola de engenharia, uma vez que nos primeiros anos a maior parte do corpo docente foi constituída pelos seus professores. Deve-se também notar que a FAUUSP por muito tempo não possuiu congregação própria, o que se realizou somente em 1968, vinte anos após sua fundação. Nesse período, os assuntos relativos à faculdade foram tratados no Conselho Universitário da USP, tornando os registros mais dispersos. Atualmente, parte significativa das pesquisas históricas relativas à faculdade ou aos seus docentes e alunos devem contar com a memória das pessoas que passaram por ela. Sem desmerecer a riqueza deste tipo de fonte, há que se reconhecer os limites de se contar com a história oral como único recurso de pesquisa e o risco de se perdê-la ou deformá-la com a passagem do tempo. Dessa forma, revelou-se a urgência em organizar um arquivo histórico que preserve a memória dessa faculdade, o que possibilitaria a realização de inúmeras pesquisas. Entretanto, nesse sentido, devemos reconhecer iniciativas pontuais que muito contribuem para a preservação da memória da FAUUSP. Dentre elas, destacamos o esforço dos funcionários do Departamento de Projeto, em particular Maria Ezilda Gratieri, em recuperar os programas das disciplinas ministradas ao longo do tempo, digitalizá-los e disponibilizá-los para consulta, o que foi fundamental para a realização deste trabalho. A contribuição de Iliete Maria Franco de Arruda, que organizou e nos disponibilizou uma relação de todos os docentes contratados pela faculdade entre 1948 e 1998, foi também de grande importância para a pesquisa.

O trabalho foi estruturado em quatro capítulos, além desta introdução e das considerações finais. No Capítulo 01, apresentamos um quadro do processo de institucionalização da arquitetura em São Paulo na década de 1940, focando-nos especialmente sobre a atuação do IAB-SP. Em seguida, nesse contexto, analisamos a estruturação da FAUUSP, buscando explicitar o conflito de interesses que a criação da faculdade suscitou e as mudanças do ensino de arquitetura ligado à Escola Politécnica para o ensino na faculdade autônoma de arquitetura. Finalmente, analisamos a formação do corpo docente da escola em seus primeiros anos de funcionamento, especialmente aqueles dedicados ao ensino de composição de arquitetura.

No Capítulo 02, situamos o papel de Anhaia Mello na fundação da FAUUSP, tendo em vista sua formação e sua atividade docente como catedrático da Escola Politécnica. Observando sua posição no campo do urbanismo, bem como a matriz de pensamento que adotou como referência, buscamos evidenciar seu interesse na separação em relação à Escola Politécnica.

No Capítulo 03, são as posições de Artigas que nos dedicamos a analisar, considerando aspectos de sua formação, de sua experiência como assistente de Anhaia Mello na Escola Politécnica, bem como sua inserção na FAUUSP. Observando sua atuação junto ao IAB-SP, procuramos também situar o arquiteto no âmbito da luta pelo fortalecimento da categoria profissional de arquitetura. Finalmente, recuperamos o sentido da Função Social da Arquitetura no seu pensamento, questão que se tornou uma bandeira da arquitetura moderna e que foi tema de seu concurso para professor titular da FAUUSP em 1984. Identificamos que o discurso do "plano" foi abraçado pelo arquiteto como meio para realizar a 
Função Social da Arquitetura.

Finalmente, no Capítulo 04, retornamos à FAUUSP para analisar as disciplinas de Urbanismo, a cargo de Anhaia Mello, e de Composição de Arquitetura, lecionadas por Artigas e seus colegas de departamento. A análise dos programas das disciplinas revelou uma iniciativa do corpo docente de composição de aproximar-se da cadeira de urbanismo, sempre mediados pelo plano como interface entre as disciplinas. Diante disso, sentimos a necessidade discutir diferenças nos significados de plano para Anhaia Mello e para Artigas. Procurando trazer à tona diferenças pouco discutidas no significado desse conceito, ligadas às matrizes de pensamento distintas que o informavam, acreditamos ter demonstrado que o uso de um vocabulário comum silenciou um debate de divergências entre os profissionais. Uma vez desfeito o silêncio, trouxemos novos elementos para a realização desse debate. 


\section{CAPÍTULO 1}

A formação do campo profissional de arquitetura e urbanismo em São Paulo e a construção da relação entre

arquitetura e urbanismo na FAUUSP 


\section{A institucionalização do campo de arquitetura e urbanismo em São Paulo}

No Brasil, as discussões e tentativas de definir as atribuições da profissão de arquitetura remontam, pelo menos, à década de 1920, mas podemos considerar que o primeiro marco regulador em nível federal se deu com o decreto-lei $n^{\circ} 23.569$ de 11 de dezembro de 1933, que dispunha sobre as profissões de engenheiro, arquiteto e agrimensor ${ }^{1}$. Esse decreto representava uma vitória dessas categorias na luta contra profissionais não diplomados que atuavam livremente no país até então. Todavia, a grande vantagem se deu para os engenheiros, que avançaram na consolidação de sua posição de prestígio entre as profissões liberais, em disputa com as carreiras jurídicas ou médicas, tidas como superiores na virada do século (ARASAWA, 1999, p. 110). Na lei, parte das atribuições de arquitetos e engenheiros civis se sobrepunham, com vantagem para os engenheiros ${ }^{2}$. O que o decreto trazia de novo era, especialmente, a exigência de diploma de nível superior para o exercício da profissão (SILVA, 2010, p. 84; DEDECCA, 2012, p. 53).

A partir de então, os arquitetos começaram uma trajetória de luta por autonomia face ao campo da engenharia. Ainda em 1930, o arquiteto Christiano Stockler das Neves ${ }^{3}$ fundou o Instituto Paulista de Arquitetos, IPA, com o intuito de defender sua categoria profissional. Em nível nacional, o Instituto de Arquitetos do Brasil, IAB, existe com esse nome desde 1936. Sua origem está no Instituto Central de Arquitetos, fundado em 1924 (RABELO, 2011, p. 13).

Todavia, foi nos anos 1940 que a categoria de arquitetos ganhou força, vinculada à ascenção da arquitetura moderna, que viria a tornar-se a arquitetura hegemônica nos meios institucionais. Alguns eventos e instituições tiveram grande relevância na luta pelo fortalecimento do campo profissional em São Paulo. Dentre elas, destacamos: a federalização do Instituto de Arquitetos do Brasil, IAB, com a criação do Departamento de São Paulo em 1943, assim como os Congressos Brasileiros de Arquitetos, CBA, realizados a partir de 1945. Ao mesmo tempo, nessa década, ampliaram-se as publicações de revistas especializadas em arquitetura. Outros meios, como os escritórios profissionais ${ }^{4}$, as instituições culturais, como o Museu de Arte de São Paulo, Masp, fundado em 1947, o Museu de Arte

1 São Paulo já possuía desde 1924 uma legislação estadual que regulamentava as profissões de arquitetos, engenheiros e agrimensores. Entretanto, possivelmente o interesse numa legislação federal se devesse à ampliação de seu poder de atuação no restante do país (RABELO, 2011, p. 54).

2 Dentre as pesquisas que trataram dessa questão, destacamos a de Rabelo (2011, p. 56), segundo quem a luta pela regulamentação da profissão visava fazer face à competição com arquitetos estrangeiros e à disputa com a engenharia. Entretanto, nada foi resolvido, visto que para os imigrantes criou-se a revalidação do diploma e, com relação aos engenheiros, esses saíram em vantagem no conjunto de atribuições. 
Moderna de São Paulo, MAM, criado em 1948, e as galerias de arte também foram espaços privilegiados de circulação de ideias em torno do campo, numa estratégia em que a arquitetura se distanciou dos procedimentos da ciência (politécnica) para se ligar aos assuntos da arte e da cultura (DEDECCA, 2012, p. 44). A essas instituições, somou-se o surgimento das primeiras faculdades autônomas de arquitetura, separadas, respectivamente, da Escola de Engenharia do Mackenzie, em 1947, e da Escola Politécnica de São Paulo, em 1948.

O IAB-SP foi fundado em 06 de novembro de $1943^{5}$. Anhaia Mello, que ocupava o cargo de Secretário de Viação e Obras Públicas, participou da solenidade de fundação como representante do Interventor Federal, Fernando Costa, coordenando a sessão. Paulo de Menezes Mendes da Rocha ${ }^{6}$, diretor da Escola Politécnica, representava aquela instituição, e Carlos Alberto Gomes Cardim Filho ${ }^{7}$ esteve presente em nome do prefeito Prestes

3 Christiano Stockler das Neves (1889-1992), filho do agrônomo Samuel das Neves, obteve o diploma de arquiteto em 1912 na Universidade da Pennsylvania, sob forte influência da École des Beaux Arts de Paris. Em 1917, fundou o curso de arquitetura da Escola de Engenharia do Mackenzie College em São Paulo. Foi também quem conduziu a separação do curso da engenharia dessa faculdade em 1947. Veemente opositor da arquitetura moderna, desde cedo defendeu a diferenciação das profissões de arquitetura e de engenharia a partir do valor artístico da arquitetura. Em favor da profissão, pautou a instituição de concursos de obras públicas, o direito autoral de projetos e a regulamentação profissional. Com esse intuito criou em 1930 o Instituto Paulista de Arquitetos, IPA. (SAMPAIO, M.R.A. de. Christiano Stockler das Neves: uma atuação polêmica. In: Revista do Instituto de Estudos Brasileiros, 35, São Paulo: IEB, 1995, p.181-196).

4 Dedecca (2012) realizou o mapeamento dos escritórios de arquitetura nos anos 1950, a partir do Índice Profissional publicado na revista AD. Esse mapeamento revelou a proximidade espacial desses escritórios, o que permitia uma intensa troca entre os arquitetos.

5 Foi a segunda seção estadual do IAB a ser criada no Brasil. A primeira foi a de Minas Gerais, em 02 de Outubro de 1943.

6 Paulo de Menezes Mendes da Rocha (1887-1967), docente catedrático da Escola Politécnica, especialista na área de recursos hídricos, dirigiu a cadeira de "Navegação Interior e Portos Marítimos". Foi diretor daquela instituição entre 1943 e 1947, período em que ocorreram os debates e preparativos para a criação da FAUUSP. O engenheiro foi pai de Paulo Archias Mendes da Rocha, arquiteto que viria a lecionar na FAUUSP a partir de 1960. Informações em http://www.poli.usp.br.

7 Carlos Alberto Gomes Cardim Filho (1899-1990) formou-se engenheiro arquiteto na Escola Politécnica em 1925, após ter-se diplomado engenheiro civil em 1923. Trabalhou na Prefeitura Municipal e foi defensor de uma regulamentação do exercício profissional mais restritiva como meio de melhorar a qualidade das construções executadas na cidade. Participou de diversos congressos profissionais. Foi Secretário de Obras e, neste cargo, integrou a Comissão Orientadora do Plano da Cidade em 1948. Aposentou-se da prefeitura como diretor do Departamento de Urbanismo em 1952. Publicou em revistas especializadas diversos artigos apresentando suas posições sobre urbanismo. Integrou o corpo editorial da revista Acrópole a partir de 1941. Com Mário de Andrade, Alexandre Albuquerque e Lopes de Leão, participou da organização do Conselho de Orientação Artística de São Paulo (Decreto Estadual n 4.965/1931), responsável pela organização dos primeiros Salões Paulistas de Belas Artes. Lecionou na FAUUSP entre 1952 e 1955, na cadeira "Arquitetura no Brasil" (FICHER, 2005, p. 215-221). 
Maia (IAB, 2008, p. 03). A ata de fundação do IAB-SP foi assinada pelos arquitetos: Eduardo Kneese de Mello ${ }^{8}$, Oswaldo Bratke ${ }^{9}$, Rino Levi, Ícaro de Castro Mello, Abelardo de Souza, Helio de Queiroz Duarte, Zenon Lotufo, Roberto Cerqueira César10, Francisco Beck, João Cacciola $^{11}$, Otavio Lotufo, Leo Ribeiro de Morais ${ }^{12}$, Miguel Forte, Hélio Uchôa, Francisco Kosuta $^{13}$, Américo Salfati e Gregori Warchavchik ${ }^{14}$, dos quais os oito primeiros viriam a

8 Eduardo Kneese de Mello (1906-1994). Engenheiro arquiteto formado pela Escola de Engenharia da Universidade Presbiteriana do Mackenzie em 1931. Envolveu-se ativamente na luta pela institucionalização da arquitetura moderna em São Paulo. Foi docente no Mackenzie (1937) e na FAU-USP (1955 a 1976), onde foi responsável pela cadeira de Arquitetura no Brasil. Dedicou-se ao estudo da pré-fabricação, que aplicou, por exemplo, no projetos do Conjunto Residencial da Universidade de São Paulo, Crusp, de 1961. Participou da equipe que projetou o Parque do Ibirapuera por ocasião do IV Centenário de São Paulo (1951 a 1964), sob coordenação do arquiteto Oscar Niemeyer. Para maiores informações, conferir, entre outros: MONTENEGRO FILHO, R. A pré-fabricação na trajetória de Eduardo Kneese de Mello. Tese de doutorado. São Paulo: FAUUSP, 2012.

9 Oswaldo Arthur Bratke (1907-1997). Engenheiro arquiteto formado pela Escola de Engenharia da Universidade Presbiteriana do Mackenzie em 1931. Em sociedade com Carlos Botti, abriu um escritório de arquitetura em 1933 no qual estagiou o então estudante Vilanova Artigas. Em 1942, desfez a sociedade, mantendo seu próprio escritório. Desenvolveu diversos projetos residenciais e o Balneário Municipal de Águas de Lindóia (1954), dentre outras obras. Participou da direção do IAB-SP entre 1952 e 1953 e em 1955.

10 Para dados biográficos de Rino Levi, Ícaro de Castro Mello, Abelardo Riedy de Souza, Hélio de Queiroz Duarte, Zenon Lotufo e Roberto Cerqueira César, consultar o Apêndice D.

11 Francisco Beck (1901-1990) arquiteto húngaro (SILVA, 2010, p. 47). João Cacciola, arquiteto nascido em Bauru. Ambos atuaram em São Paulo.

12 Leo Ribeiro de Morais (1912-1978). Iniciou sua formação na Escola de Engenharia do Mackenzie College em 1932, transferindo-se para o curso de engenheiros arquitetos da Escola Politécnica de São Paulo em 1933. Formou-se em 1939. Ocupou cargos da administração estadual e participou de agremiações de classe. Pertenceu aos quadros do Partido Comunista Brasileiro, PCB. A partir de 1942 particiou da Sociedade Amigos da Cidade, SAC, apoiando as concepções urbanísticas de Anhaia Mello, de quem fora aluno. Foi um dos fundadores do IAB-SP e partidário da arquitetura moderna (FICHER, 2005, p. 310-311).

13 Miguel Forte (1915-2002). Seguiu o curso de engenheiros arquitetos do Mackenzie entre 1934 e 1939, tendo lecionado no curso de arquitetura da mesma instituição a partir de 1964. Estagiou no escritório de Rino Levi durante a graduação. Defensor da arquitetura moderna, enfrentou as posições acadêmicas de Christiano Stockler das Neves no Mackenzie. (http://www.vitruvius.com.br/ revistas/read/arquitextos/03.030/732); Hélio Uchôa (1913-1961), arquiteto carioca diplomado em 1934 pela Escola Nacional de Belas Artes, ENBA, participou com Zenon Lotufo e Eduardo Kneese de Mello da equipe liderada por Oscar Niemeyer para a elaboração do projeto do complexo do Parque Ibirapuera em 1951 (http://www.brasilartesenciclopedias.com.br/ nacional/ uchoa_helio. htm); Francisco José Esteves Kosuta, engenheiro arquiteto formado no Mackenzie, instituição em que lecionou e da qual foi diretor entre 1961 e 1962 (DEDECCA, 2012, p. 89).

14 Gregori Warchavichik (1896-1972) Arquiteto ucraniano residente em São Paulo e naturalizado brasileiro. Estudou arquitetura em Roma com o arquiteto italiano Marcelo Piacentini. Autor do 
lecionar na FAUUSP. Após a criação do IAB-SP, os arquitetos, à procura da diferenciação da engenharia, como parte da estratégia para viabilizar a hegemonia da arquitetura moderna, em uma vertente específica que se distinguisse da arquitetura moderna carioca já consolidada, passaram a distanciar-se das instituições ligadas à politécnica, como o Instituto de Engenharia, IE, e suas revistas especializadas, como os Boletins do IE, Revista Politécnica, etc. (DEDECCA, 2012, p. 43). Entretanto, antes disso, existia uma inserção desses profissionais nesses meios, a exemplo de Eduardo Kneese de Mello, que participou do V Congresso Panamericano de Arquitetos, em 1940, enquanto representante do IE. Ademais, deve-se assinalar que foi nesse instituto que Le Corbusier proferiu sua série de conferências sobre arquitetura e urbanismo em 1929, durante sua estadia em São Paulo (LIRA, 2005, p. 07).

O IAB fez um esforço em divulgar nos meios profissionais estrangeiros e atraí-los para os eventos realizados no Brasil. Eduardo Kneese de Mello e Armando Ciampollini realizaram viagens para esse fim, o que resultou na participação de arquitetos como Alvar Aalto, Max Bill, Walter Gropius, Junko Sakakura, Eugène Freyssinet, Mathew Nowicki, Auguste Perret, Frank Lloyd Wright, Ernesto Nathan Rogers, Josep Luis Sert, Le Corbusier, Kenzo Tange, Marcel Breuer e Philip Johnson nas Bienais de Arquitetura a partir dos anos 1950 e nas Exposições Internacionais de Arquitetura, realizadas em 1948 e 1952 (DEDECCA, 2012, p. 51).

É importante também destacar que a luta pela autonomia do campo de arquitetura em São Paulo se relacionava com processos ocorridos não apenas no contexto nacional, mas também internacional. Fora do Brasil, alguns institutos podem ter estabelecido um ponto de contato com os arquitetos brasileiros. Apesar de, nos anos 1930, Le Corbusier ter designado Warchavchik como representante brasileiro nos Congressos Internacionais de Arquitetura Moderna, CIAM, o Brasil não chegou a participar diretamente desses eventos. A União Internacional dos Arquitetos, UIA, parece ter sido um espaço no qual o Brasil teve maior participação, tendo tido representantes no seu Conselho Executivo e, cargos de direção ocupados por brasileiros. A UIA foi criada em 1948, em Lausanne, na Suíça. Há registro da participação de arquitetos brasileiros nesse evento desde, pelo menos, o III Congresso Mundial da UIA, em 1952. Também, no contexto continental, os Congressos Pan-americanos de Arquitetos constituíram espaços de fortalecimento institucional, além de outros encontros e congressos realizados na América Latina.

14 primeiro manifesto em defesa da arquitetura moderna no Brasil (1925) e do projeto da "Casa Modernista” (1928) em São Paulo, obra pioneira da arquitetura moderna em São Paulo. Foi indicado por Le Corbusier, quando de sua vinda ao Brasil, para representar o Brasil nos Congressos Internacionais de Arquitetura Moderno, CIAM. A convite de Lúcio Costa, lecionou na ENBA entre 1930 e 1932 (FERRAZ, G. Warchavchik e a introdução da nova arquitetura no Brasil: 1925 a 1940. São Paulo: Ed. Masp, 1965). 


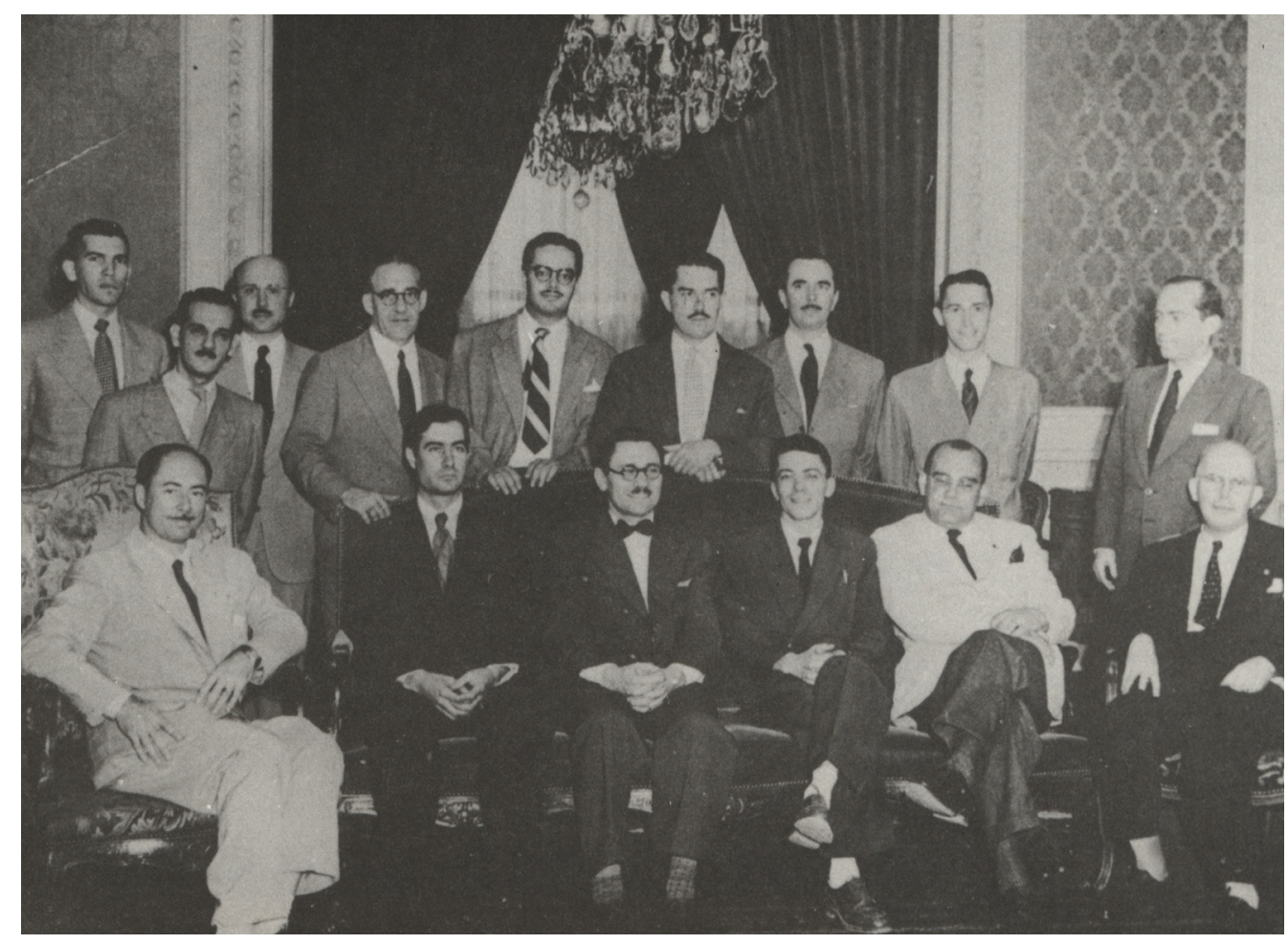

Figura I - Jantar comemorativo da fundação do IAB-SP. Artigas, sentado, é o $3^{\circ}$ da direita para a esquerda e Eduardo Kneese de Mello, sócio $\mathrm{n}^{\circ} 01$ do IAB-SP, está de terno branco.

A análise das instituições assinaladas permite observar como foi se delineando, a partir dos anos 1940 e, especialmente, dos anos 1950, a opção pela arquitetura moderna como a linguagem a ser seguida pelos arquitetos a elas filiados. Por outro lado, podemos identificar quais seriam as atribuições dos arquitetos que os diferenciariam das demais profissões ligadas à construção civil. Observamos, com base na análise da documentação relativa a essas instituições, assim como na bibliografia sobre o tema, algumas questões que nortearam as reivindicações por autonomia da categoria: a atividade de projeto e a constituição da arquitetura como uma profissão liberal, o urbanismo e a habitação popular.

A disputa pelo urbanismo como atribuição profissional no Brasil remonta pelo menos à segunda metade da década de 1920, quando o curso de urbanismo passou a compor o currículo dos arquitetos da Escola Nacional de Belas Artes, ENBA (RABELO, 2011, p. 88) e dos engenheiros arquitetos da Escola Politécnica de São Paulo. Essa disputa se deu, especialmente, no Rio de Janeiro ${ }^{15}$, visto que no curso da escola paulista a questão

15 A ENBA, naquela altura, estava empenhada em obter sua inclusão no rol de instituições de ensino superior do Brasil, atribuindo-se lhe um nível de "cientificidade" que não competia às instituições de ensino artístico (RABELO, 2011, p. 35) 
da distinção entre a engenharia e a arquitetura iria ganhar maior relevância mais adiante. Durante o IV Congresso Panamericano de Arquitetos, realizado no Rio de Janeiro em 1930, José Marianno Filho ${ }^{16}$, desencadeou uma grande polêmica ao defender que somente os arquitetos poderiam exercer a atividade urbanística. Seu posicionamento causou tanto descontentamento que alguns engenheiros chegaram a deixar o recinto (RABELO, 2011, p. 53). De todo modo, foi por volta desse período (a partir de 1925) que se fortaleceu a figura do arquiteto-urbanista, dedicada ao projeto e planejamento urbanos, tanto na formação quanto na prática profissionais. Em São Paulo, todavia, a prática do urbanismo permaneceu principalmente nas mãos de engenheiros, sobretudo nos setores municipais de urbanismo e de viação e obras públicas.

Desde o I CBA, em 1945, o urbanismo como "problema de arquitetura" (IAB-SP, 1945, 21) passou a ser reiteradamente debatido nesses encontros. Em 1959, o IAB apresentou ao Conselho Federal de Engenharia, Arquitetura e Agrimensura/ Conselho Regional de Engenharia, Arquitetura e Agrimensura, Confea/Crea, uma proposta de regulamentação da profissão que previa a criação de um órgão profissional específico para arquitetos, reivindicando, dentre outras pautas, o urbanismo como atribuição exclusiva desses profissionais. Como veremos nesta dissertação, essa proposta engendrou grandes disputas. Esses arquitetos, em um primeiro momento, não defendiam que arquitetura e urbanismo constituíssem um único campo, mas sim que o urbanismo (ou sua coordenação) deveria ser uma atribuição exclusiva do arquiteto (especializado) e não compartilhada com os engenheiros, superando as "falhas" da regulamentação de 1933.

Rabelo (2011, p. 57) apontou ainda que além das atividades de projeto e de urbanismo, outro campo de atuação que foi objeto de disputa entre arquitetos e engenheiros foi a habitação econômica. Ao longo da década de 1930, a disputa foi sendo vencida pelos arquitetos, coincidindo com o período em que as ideias da moradia como um direito e da responsabilidade do Estado por sua provisão ganharam força ${ }^{17}$.

16 José Marianno Carneiro da Cunha Filho (1881-1946), Pernambucano, mudou-se para o Rio de Janeiro aos 12 anos de idade, em 1893. Formou-se em medicina, mas não chegou a exercer a profissão. É tido como "mecenas" da arquitetura neocolonial, professor da ENBA e seu diretor entre 1926 e 1927. Foi um dos grandes opositores da arquitetura moderna. É digno de nota o confrontamento entre ele e Lúcio Costa quando este esteve à frente da direção da ENBA em 1931.

17 Em São Paulo aconteceu, em 1931, o I Congresso de Habitação, durante a gestão de Anhaia Mello na Prefeitura Municipal. 
Deve-se também notar que cada uma das instituições de arquitetura e urbanismo que foram sendo criadas ao longo do século XX em São Paulo não eram estanques e isoladas entre si, mas houve uma interação entre elas para o desenvolvimento de determinadas atividades. Por exemplo, o IAB-SP associou-se aos diretórios acadêmicos da FAUUSP e do Mackenzie para a organização de cursos. Além disso, os mesmos profissionais atuaram em diversas dessas instituições ao mesmo tempo. Muitos professores da FAUUSP fundaram o IAB-SP ou participaram de sua direção - Rino Levi, Eduardo Kneese de Mello, Ícaro de Castro Mello, Roberto Cerqueira César, Abelardo de Souza, Luiz Roberto de Carvalho Franco, Carlos Alberto Gomes Cardim Filho, Artigas, dentre outros - ao mesmo tempo em que participavam do corpo editorial de revistas especializadas - Eduardo Kneese de Mello e Carlos Alberto Gomes Cardim Filho na Revista Acrópole, Abelardo de Souza em Habitat, Eduardo Corona e Artigas em AD - e assim por diante.

\section{A consolidação da FAUUSP como uma escola de arquitetura moderna}

\subsection{Arquitetura como Composição}

Em São Paulo, a arquitetura, começou a ser ensinada na Escola Politécnica, no curso de engenheiros arquitetos, a partir de $1894^{18}$. O ensino de arquitetura, concebido como uma especialidade da engenharia, atribuía aos seus diplomados a habilitação de projetar e construir edifícios, diferentemente dos engenheiros civis, que deveriam projetar e construir obras de engenharia (FICHER, 2005, p. 26). A formação nessa escola era organizada em um "curso fundamental" de três anos de duração (constituído por um ano de "curso preliminar" e dois anos de "curso geral"), comum a todos os estudantes que ingressavam na Escola Politécnica, além de dois anos de cursos especiais, em que eram ministradas as matérias relativas à especialidade escolhida.

Nas estruturas curriculares propostas ao longo da existência do curso, observa-se, de modo geral, que as cadeiras ministradas exclusivamente aos aspirantes a engenheiros arquitetos eram aquelas ligadas à "Composição" - Composição Geral, Composição Decorati-

$18 \mathrm{O}$ curso de engenheiros arquitetos foi criado no $2^{\circ}$ regulamento da Escola Politécncica, aprovado no Decreto $\mathrm{n}^{\circ} 270$-A de 1894 . Outros regulamentos em que houve alguma alteração significativa na estrutura do curso de engenheiros arquitetos foram o $6^{\circ}$ Regulamento (Decreto $n^{\circ} 2.931$ de 12 de junho de 1918), $7^{\circ}$ Regulamento (Decreto $n^{\circ} 2.128$ de 1925), $9^{\circ}$ Regulamento (Decreto $n^{\circ}$ 7.071 de 06 de abril 1935, primeiro regulamento após a criação da Universidade de São Paulo, através do Decreto ${ }^{\circ} 6.533$ de 04 de julho de 1934) e 10 Regulamento (Decreto $n^{\circ} 10.048$ de 1939 e Decreto $n^{\circ} 11.022$ de 1940), conforme análise de Ficher (2005, p. 26-27). 
va - além de aulas de desenho, de estética, de história da arquitetura e das artes, disciplinas que se destinavam ao estudo dos estilos (FICHER, 2005, p. 49). Dessas, aquela que ocupava o maior tempo de formação dos estudantes era a cadeira de composição de arquitetura.

De acordo com Ficher (1988, p. 129) a "composição" foi objeto de teorização tanto na orientação "Belas Artes" (Élements e Théorie de l'Architecture, 1901-1904, de Guadet), em que o edifício era montado a partir da organização de suas partes e volumes, quanto na orientação "Politécnica" (Précis d'Architecture Donnés à l'École Polytechnique, 1802-05, Durand), para a qual a forma correta estava associada à racionalização da distribuição pela composição segundo traçados regulares e ao estudo dos diversos tipos de edificação. Em São Paulo, também se deve ter em conta a influência da formação de Francisco de Paula Ramos de Azevedo ${ }^{19}$ (1851-1928) em Gand, Bélgica, onde foi aluno de Louis Cloquet, cujo “Traité d'Architecture: Eléments d'Architecture, Types d'Edifices, Esthétique, Composition et Pratique de l'Architecture", de 1898, foi incluído na bibliografia técnica da Escola Politécnica de São Paulo em 1899 (CARVALHO, 1996, p. 124). O ensino baseado na composição arquitetônica foi aplicado ao ensino politécnico e transplantado para o curso da Faculdade de Arquitetura e Urbanismo, quando de sua fundação em 1948. Como veremos a seguir, ao longo da década de 1950, parte do corpo docente responsável pelo ensino de Composição passou a questionar esses métodos, transformando suas disciplinas para, finalmente, extinguir essas cadeiras em 1962.

No contexto internacional, a crítica aos métodos de composição de arquitetura atravessou a vanguarda do Movimento Moderno. De acordo com Colquhoun, entretanto, não se construiu um "antônimo" para a "composição", mas esta, na Europa, simplesmente foi excluída do vocabulário do pós-guerra [da Primeira Guerra Mundial], "típica de um clima arquitetônico moral, utilitário e pragmático” (COLQUHOUN, 2004, p. 49).

A composição, em seu sentido moderno remonta ao século XIX. Entretanto, o conjunto de ideias ao qual ela deve sua origem tem raízes na Antiguidade. Ela diz respeito à noção de se dispor as partes da arquitetura como elementos de uma sintaxe, e de acordo com certas regras a priori, para se formar um todo (COLQUHOUN, 2004, p. 57). A adoção do termo se difundiu principalmente durante o século XIX, vinculada ao fenômeno do ecletismo. Tratava-se de estabelecer as regras de desenho comuns a todos os estilos. Todavia, a criação de um sistema de combinações por Guadet decorreu de uma redução a "algarismos e cifras" diante do enfraquecimento de significados expressos pelas figuras clássicas.

No contexto do colapso da "convição estilística", tanto os franceses quanto os ingleses dependiam cada vez mais de fórmulas compositivas, fossem elas mais ou menos regulares, como na École des Beaux-Arts, ou irregulares e pitorescas, como no revivalismo gótico inglês ou no estilo livre (COLQUHOUN, 2004, p. 53).

19 Importante arquiteto da Primeira República em São Paulo, Ramos de Azevedo foi também o mais influente docente do curso de Engenheiros Arquitetos da Escola Politécnica nas primeiras décadas de existência do curso. 
No início do século XX, a despeito da aversão que a "composição arquitetônica" suscitou nos meios de vanguarda, ao remeter à tradição acadêmica, Colquhoun observou uma continuidade desse método dentro da arquitetura "funcionalista", não tendo ocorrido propriamente uma ruptura entre a "composição" vinda da tradição clássica e a arquitetura moderna. Segundo ele, o que se deu foi que, no anseio por libertar-se da imitação de modelos do passado, o funcionalismo transferiu o "significado" do edifício da forma para seu conteúdo (o "programa arquitetônico"). Entretanto, esse processo fundou-se em procedimentos compositivos, visando evitar a repetição de soluções formais. Nas palavras do autor:

A função, nesse sistema de ideias, fornece a lógica do jogo compositivo. Serve também como catalisadora. A principal diferença entre o modernismo e a composição clássica é que naquele existe um alto grau de liberdade nas relações entre as partes e não porque seus proprios elementos sejam infinitos (COLQUHOUN, 2004, p. 51).

Ainda nesse sentido, o autor observou que:

Nos inúmeros projetos que normalmente antecedem as soluções finais de Le Corbusier (...) pode-se sentir a emoşão com que o arquiteto brinca com todas as permutações de relações entre os elementos fixos. (...) O que os diferencia da composição acadêmica é até que ponto esses tipos de desenho estão livres de combinação fixa e são ativos e dinâmicos em seu livre jogo de formas, e não a presença ou ausência de composição como tal (idem, p. 51-2).

Dessa forma, Colquhoun concluiu que a ideia de composição foi herdada pela vanguarda do século XX diretamente da tradição acadêmica, de modo que um movimento "revolucionário" tomava emprestadas as estruturas e instituições que procurava destruir. No mesmo sentido, Banham assinalou que a atitude dos que viriam a se tornar mestres da arquitetura moderna na Europa tenderam a olhar para a tradição acadêmica de forma ambígua. Viam-na com desconfiança ao mesmo tempo em que retomavam seus conceitos:

Assim, Gropius, em 1923, após criticar as academias por não estimularem a ciência estética, prossegue nos parágrafos seguintes fazendo uso de um certo número de conceitos estéticos que se assemelham àqueles de origem acadêmica francesa (BANHAM, 1975, p. 25).

Portanto, a crítica à composição por parte do corpo docente da FAUUSP nos anos 1950 não deve ser apenas entendida como uma reação às "heranças politécnicas", mas também como absorção da crítica modernista à tradição clássica em seu contexto internacional. Crítica que não correspondia a uma completa superação, como observaram Colquhoun e Banham. Isso deve ser também compreendido no sentido de que a luta por autonomia não correspondia a uma crítica aos engenheiros, mas sim à disputa pela consolidação da arquitetura moderna. 


\subsection{Mudanças na estrutura curricular da FAUUSP}

\subsubsection{8-1962: Consolidação Institucional}

Os anos que vão da fundação da FAUUSP à reforma curricular de 1962 podem ser considerados uma fase de consolidação institucional. Criada a partir do curso de engenheiros arquitetos da Escola Politécnica, passaram-se sete anos até a aprovação de seu primeiro regulamento interno. Ainda assim, até 1968 a faculdade não possuía congregação própria, em razão do número insuficiente de professores catedráticos. De acordo com a Lei $\mathrm{n}^{\circ} 104$ de 21 de junho de 1948, que criava a FAUUSP, a instalação do curso de arquitetura se daria de modo progressivo: em 1948 seria aberto o $1^{\circ}$ ano do curso, em 1949, o $2^{\circ}$ ano e assim sucessivamente até a instalação de todos os anos letivos. Concomitantemente, a Escola Politécnica deixaria de conceder matrículas para o curso de engenheiros arquitetos, que deveria ser extinto gradativamente ${ }^{20}$. O primeiro vestibular aconteceu entre os dias 2 e 5 de agosto de $1948^{21}$. No Anexo A é possível observar as diferentes estruturas curriculares do curso entre 1948 e 1962.

A princípio, o curso de Arquitetura seria ministrado para a graduação e o curso de Urbanismo seguiria na forma de pós-graduação para engenheiros civis e arquitetos, a ser implantado a partir de 1949. A lei de fundação previa que fosse elaborado o regulamento da faculdade, finalmente aprovado em 1955, com a publicação da Lei $n^{\circ} 3.233$. O curso de pós-graduação em urbanismo, tal como previsto na Lei n ${ }^{\circ}$ 104/1948, não chegou a ser criado, mas em 1955 essa perspectiva era mantida. Foi apenas em 1961, com a promulgação da Portaria $n^{\circ} 09$, que fixava os currículos do curso para o ano seguinte, que se deixou de mencioná-lo, falando-se em um único curso de graduação que contemplasse os conteúdos de arquitetura e de urbanismo. Certamente, a ideia de um curso de "arquitetura e urbanismo" alinhava-se às ideias que gestaram a reforma de 1962 .

No curso de engenheiros arquitetos da Escola Politécnica, o ensino de Composição Arquitetônica partia dos componentes (elementos de apoio, elementos apoiados, "seções"

20 O curso de engenheiros arquitetos foi definitivamente extinto no inicio de 1954. Com isso, a cadeira de Anhaia Mello na Escola Politécnica, que lecionava unicamente aos alunos daquele curso, também deixou de existir. A partir de então, Anhaia Mello foi transferido para a Cadeira $n^{\circ} 12$ da Escola Politécnica, "Noções de Arquitetura e Construções Civis, Higiene das Habitações, $1^{\mathrm{a}}$ e $2^{\mathrm{a}}$ Partes”, que ministrava matérias aos cursos de Engenheiros Civis e de Engenheiros Mecânicos e Eletricistas (Processo EP 104/1953, Publicação no DOSP de 14/09/1953). Artigas, que era Assistente de Anhaia Mello naquela Cadeira, foi relotado na Faculdade de Arquitetura e Urbanismo para exercer o mesmo cargo que exercia anteriormente na Escola Politécnica (Processo EP 144/1956, Publicação no DOSP de 18/06/1956). É interessante observar que o empenho do urbanista em criar a FAUUSP não implicou, de modo algum, uma ruptura com a Escola Politécnica, como os documentos constantes no Processo referente à transferência revelaram. 
dos edifícios) no $3^{\circ}$ ano do curso, para no $4^{\circ}$ e $5^{\circ}$ anos, proporem soluções para diferentes programas arquitetônicos (edifícios privados e públicos ou de utilidade pública) pela associação dos diferentes elementos. Discutiam-se questões relativas à situação, orientação, clima e materiais e aos aspectos de distribuição e equilíbrio das massas ${ }^{22}$. Ao mesmo tempo, alunos de $4^{\circ}$ ano assistiam a um curso de Estética e os de $5^{\circ}$ ano estudavam Urbanismo.

Anhaia Mello foi o docente responsável pela cadeira de "Estética. Composição Geral e Urbanismo - $1^{\text {a }}$ e $2^{\text {a }}$ Partes" da Escola Politécnica a partir de 1926. Apesar de ter se tornado o catedrático de composição de arquitetura, seu principal interesse era o urbanismo. Ao longo de sua carreira, esteve atualizado com relação ao que era produzido sobre o assunto no plano internacional e difundia essas ideias em suas aulas e suas publicações nas revistas de engenharia. Deve-se considerar ainda que seus assistentes devem ter tido um papel relevante no ensino dos conteúdos relativos à arquitetura no âmbito da cadeira sob sua responsabilidade ${ }^{23}$.

Na FAUUSP, entre 1948 e 1962, os conteúdos relativos ao projeto na escala do edifício, assim como os aspectos plásticos da arquitetura, estavam organizados em quatro Cadeiras. A Cadeira $n^{\circ} 16$, de "Pequenas Composições $-1^{\text {a }}$ Parte" era ministrada a estudantes de $1^{\circ}$ e $2^{\circ}$ ano. A Cadeira $n^{\circ} 17$, de "Pequenas Composições $-2^{a}$ Parte", voltava-se para alunos de $3^{\circ}$ ano; a Cadeira $n^{\circ} 18$, de "Grandes Composições - $1^{\text {a }}$ Parte", para alunos de $4^{\circ}$ ano e a $n^{\circ} 19$, "Grandes Composições $-2^{\text {a }}$ Parte", para os alunos de $5^{\circ}$ ano. A princípio previa-se a complexidade do trabalho proposto fosse crescendo em função da complexidade do programa, iniciando-se com um projeto residencial de pequeno porte no primeiro ano e ampliando-se até os equipamentos públicos e grandes estruturas urbanas, no último ano. No decorrer da década, como veremos a seguir, essa forma de relacionar as disciplinas foi se

22 MONDENESE FILHO (2008, p. 52) apontou a semelhança entre os programas de Anhaia Mello e a estrutura dos cursos de Guadet e Durand.

23 O depoimento de um aluno seu, Roberto Cerqueira César, futuro docente na FAUUSP, oferece indícios de como a questão da arquitetura era trabalhada em sua disciplina: "Embora Anhaia Mello não fizesse esta arquitetura moderna, a forma como ele a apresentava na época era extremamente avançada, com grande isenção, lucidez e preparação (...) ele conhecia aqueles movimentos renovadores da arquitetura (...) e nós fazíamos arquitetura moderna, não havia aquele veto violento como no Mackenzie. Evidentemente, havia a obrigação de conhecer todos os estilos, mas quando tínhamos que projetar algo, não era obrigatório fazer um projeto de estilo. Tínhamos liberdade, inclusive porque o Anhaia tinha assistentes, como por exemplo o Artigas e o Lotufo, homens de sua confiança (...) discutia-se Le Corbusier, Frank Lloyd Wright e os outros modernos com toda a liberdade" (apud FICHER, 2005, p. 151). Anhaia Mello também ensinava o Urbanismo de Le Corbusier em suas aulas, como revelam notas de aulas e textos do urbanista. A partir de 1954 Anhaia Mello, à frente da Comissão da Cidade Universitária, convocou, para projetar os edifícios do campus da Cidade Universitária, um grupo de arquitetos de orientação moderna (FICHER, 2005, p. 286), dentre eles: Artigas (FAUUSP), Icaro de Castro Mello (setor esportivo), Eduardo Corona (Historia e Geografia), Rino Levi e Cerqueira César (Setor Residencial de Estudantes, Maternidade Universitária e Centro Cívico). Isso reforça a ideia de que mesmo não sendo um arquiteto moderno, para Anhaia Mello interessava fundar uma faculdade de arquitetura moderna. 
perdendo, de modo que pouca diferença se revela nos objetivos e conteúdos enunciados nos programas de Grandes ou Pequenas Composições. Cada cadeira continha também disciplinas de desenho arquitetônico e de Plástica (I, II, III e IV). Dentro dessa estrutura, ao longo dos anos 1950, os cursos sofreram certas alterações que antecipavam a revisão da estrutura do curso nos anos 1960, com a reforma curricular que se empreendeu em 1962. O ensino de Urbanismo mereceu uma cadeira à parte, que permaneceu a cargo de Anhaia Mello até sua aposentadoria em $1961^{24}$.

\subsubsection{Os debates que antecederam a reforma curricular da FAUUSP de 1962}

Outros trabalhos já trataram das reformas de ensino empreendidas na FAUUSP ${ }^{25}$. Nesta dissertação, procuramos situar de que modo as reformas curriculares, tal como foram pensadas e discutidas, permitem identificar a forma como foi construída a relação entre arquitetura e urbanismo. Contudo, a guisa de contextualização, é necessário apresentar um breve panorama do debate sobre o ensino e das reformas de ensino que dele decorreram.

A fundação da FAUUSP foi mobilizada por uma diversidade de interesses, por vezes incompatíveis entre si. Nos anos 1940, fatores como a reestruturação do curso de arquitetura do Rio de Janeiro em 1945 e as transformações culturais e urbanas vividas em São Paulo e no país encorajaram um grupo de arquitetos a reivindicar a criação de um curso de arquitetura desvinculado do curso de engenharia em São Paulo. O engenheiro Carlos Alberto Gomes Cardim Filho, por exemplo, já defendia a criação de uma "Escola Superior de Arquitetura, da Universidade - sem ligação com a Escola Politécnica, nem com a Escola de Belas Artes" em 1941. Isso seria a resposta para a "falta de concepção artística" nas construções paulistanas (apud FICHER, 2005, p. 220). Em 1946, em seguida à criação da Faculdade Nacional de Arquitetura, FNA, no Rio de Janeiro, ele e outros membros do Conselho

24 É curioso observar a diferença entre as cadeiras de Composição de Arquitetura, que contaram com um grande número de docentes e que tiveram alguma rotatividade ao longo da década de 1950 e a cadeira de Urbanismo, dirigida por Anhaia Mello desde o início do curso até sua aposentadoria.

25 Dentre os trabalhos que trataram das reformas curriculares da FAUUSP estão os de Albuquerque (2004) e de Naruto (2006). Outras pesquisas abordam essa questão priorizando a institucionalização do ensino de Desenho Industrial, com a criação do Grupo de Disciplinas de Desenho Industrial, com as sequência de Desenho Industrial e Comunicação Visual. Para maiores informações, conferir: PEREIRA (2009), NIEMEYER (1997); KATINSKY (1983). 
de Orientação Artística de São Paulo reiteraram essa proposta, encaminhando um ofício à Congregação da Escola Politécnica ${ }^{26}$.

O fortalecimento institucional da arquitetura, através da criação do IAB-SP, também ampliou a reivindicação por escolas autônomas. Essa questão foi levantada já no primeiro CBA organizado por arquele instituto, quando o ensino de arquitetura foi apresentado como um dos "assuntos de interesse imediato da profissão" (IAB-SP, 1945). Nas discussões ocorridas nos encontros de arquitetos a partir de então, arquitetura e urbanismo tendiam a aparecer como dois campos e se desenvolviam em dois lugares sociais distintos: a arquitetura moderna tinha por espaço privilegiado de debate o IAB e seus congressos, enquanto o urbanismo era pensado no contexto de pesquisas de pós-graduação e de institutos de pesquisa.

Na Escola Politécnica, Anhaia Mello foi o docente encarregado de coordenar os trabalhos de implantação da FAUUSP. Entre 1946 e 1947, Artigas, seu assistente na cadeira de Composição Geral e Urbanismo, empreendeu uma viagem aos Estados Unidos, com o apoio de Anhaia Mello e da própria Escola Politécnica, sob a justificativa de estudar o sistema de ensino das escolas de arquitetura norte-americanas, a fim de colaborar para a estruturação do curso da USP. Sua correspondência com o arquiteto Oswaldo Corrêa Gonçalves naquele período revelou que esses e outros arquitetos ligados ao IAB-SP procuravam construir um projeto de ensino que rompesse com a estrutura do ensino politécnico, orientado para a arquitetura moderna. O arquiteto manifestou seu interesse em conhecer outras referências além das escolas consagradas ${ }^{27}$, procurando alternativas ao ensino tradicional. Artigas deixou transparecer uma polarização de interesses na formação da nova faculdade em São Paulo:

Em primeiro lugar, não estou certo se eles estão interessados na nossa escola. É muito mais necessário que nós estejamos interessados. Já mandei há mais de um mês todo o material que pude colecionar a respeito das universidades para o Dr. Anhaia. Com algumas anotações e sem procurar forçar. Ele já recebeu por certo. (Carta de Artigas a Oswaldo Corrêa Gonçalves, 27/12/1946).

De sua fala, podemos supor que um dos grupos estava ligado à estrutura dirigente da Universidade de São Paulo (Governo do Estado, Reitoria da USP, Congregação da Escola Politécnica) e detinha o poder de decisão. O outro grupo estava interessado no fortalecimento da arquitetura moderna em São Paulo e na valorização profissional, encontrando na criação da nova faculdade e na perspectiva de renovação do ensino uma oportunidade

26 Ofício D-109/1946, na Pasta Funcional de Anhaia Mello. Assinaram o ofício os representantes desse Conselho: Carlos Alberto Gomes Cardim Filho, José Marques Campão, Mozart Tavares de Lima, Armando Belardi, José Maria da Silva Neves e Theodoro Braga.

27 Artigas contou que fora levado a Boston para estudar nas duas mais renomadas instituições do país, o Massachusetts Institute of Technology, MIT, e Harvard. 
de implementar tal projeto. Todavia, esses arquitetos precisavam lançar mão de formas de convencimento daqueles responsáveis por decidir o futuro da instituição.

Artigas, por sua inserção no universo docente da Escola Politécnica e por sua relação com Anhaia Mello, foi um elemento-chave nesse processo, estabelecendo a ponte entre os dois grupos. Tratava, portanto, de persuadir Anhaia Mello sobre seus objetivos: "Eu não posso contar ou influir por carta o Anhaia por agora. A realidade é que eles não sabem o que fazer. Eu mesmo só saberei quando concluir os estudos que estou fazendo" (ARTIGAS, 1946). O arquiteto também demonstrava consciência da dificuldade de construir uma escola integralmente conforme os seus objetivos e de seus colegas, considerando a estrutura sobre a qual ela seria fundada ${ }^{28}$.

Relativamente ao modelo de ensino a ser adotado, Artigas rejeitava a reprodução do programa da escola carioca, a Faculdade Nacional de Arquitetura, FNA (ARTIGAS, 1946), contrariando a defesa que Anhaia Mello fizera da importância de criar uma faculdade de arquitetura com base naquele modelo ${ }^{29}$. Por um lado, isso reflete uma disputa, em que se fazia necessário romper com a corrente hegemônica da arquitetura moderna brasileira. Por outro, Artigas revelava a ambição de construir algo completamente novo, que rompesse com todas as referências já estabelecidas tanto nacionalmente (FNA) quanto internacionalmente (Harvard, MIT), enfatizando que "uma escola de arquitetura deve estar intimamente ligada com a indústria e o povo e tudo o mais, do país a que serve" (idem, ibidem).

Artigas também se preocupava com a constituição do corpo docente da nova escola, especialmente em relação às cadeiras técnicas, temendo que fossem destinados quaisquer professores da Politéncica, na ideia de que "arquiteto não precisa conhecer muito isso". Condizente com a ambição do projeto, deveriam ser contratados os melhores professores, insistindo-se que do tipo de ensino dessas cadeiras básicas iria depender o curso.

Todavia, apesar das descobertas de Artigas em sua viagem e do seu empenho, junto com seus colegas, para que a escola em gestação fosse a mais moderna, concentrando os melhores profissionais, o fato é que a faculdade recém-criada acabou adotando uma grade curricular bastante semelhante à da faculdade do Rio de Janeiro ${ }^{30}$ e os velhos professores da Poli foram mesmo lecionar na escola. Por outro lado, Anhaia Mello uniu-se aos arquitetos no projeto de construir uma faculdade de arquitetura moderna, apoiando a contratação de um corpo docente alinhado com essa perspectiva, como veremos a seguir. Portanto, ao ser criada a FAUUSP, buscava-se, por um lado, construir a melhor e mais moderna faculdade. Por outro, ela estava vinculada a uma instituição de ensino bastante conservadora e a estrutura curricular implantada não superava as suas raízes politécnicas. Isso levou à

28 Naruto observou que a consolidação do programa de ensino da FAUUSP, mesmo em suas propostas mais renovadoras, como na Reforma de 1962, sempre foi implantada sobre uma estrutura conservadora, em função da instituição em que estava inserida (NARUTO, 2006, p. 40).

29 Ata da $641^{a}$ sessão da Congregação da Escola Politécnica, 24/10/1946.

30 Conforme comparação de grade curricular disponível em:

http://www.dearquiteturas.com/2012/03/FAUUSP-50-anos-da-reforma-de-ensino-de_21.html 
acomodação do conteúdo em um programa de ensino que já no fim daquela década, apenas artificialmente se encaixava na grade curricular. Como veremos adiante, na análise das cadeiras de Composição do novo curso, ao longo dos anos 1950, foi dentro dessa estrutura instituída que o corpo docente passou a moldar as disciplinas conforme o que acreditava ser o papel da arquitetura, inserindo questões que ganhavam centralidade nos debates do meio profissional.

Em um contexto mais amplo, concomitante às transformações observadas nas cadeiras de composição, aconteciam debates internos e externos à faculdade em que se reivindicavam mudanças no ensino de arquitetura e urbanismo. Dessas discussões participaram profissionais de arquitetura, docentes universitários e estudantes. Em nível federal, a partir de 1957, passaram a ser organizados os Encontros Nacionais de Arquitetos, Professores e Estudantes de Arquitetura, que promoveram vários Fóruns de debate acerca da formulação de um currículo mínimo para os cursos de arquitetura (SEGAWA, 1997, p. 146).

Em São Paulo e, especialmente, dentro da FAUUSP, as discussões sobre ensino, motivadas pelo corpo docente e discente, ocorreram desde a fundação da Escola. Antes mesmo da criação da faculdade, em 1948, os estudantes inscritos no vestibular daquele ano pressionaram a Assembleia Legislativa para a efeitvação da fundação da escola ainda naquele ano. Além disso, fizeram greves para exigir a modernização da escola, a exemplo do que ocorreu em 1951, quando se recusou a contratação de Oscar Niemeyer (SODRÉ, 2010, p. 155) ou em 1959, resultando na contratação de Carlos Millán (MATERA, 2005, p. 94). Após a aprovação do primeiro regulamento da FAUUSP, em 1955, intensificou-se a realização de seminários internos para discussão do ensino. Em 1956, ocorreu um Seminário em que o grêmio estudantil, Gfau, criticava a "herança politécnica", que recaía, principalmente, sobre o método de ensino das cadeiras científicas. Na visão dos alunos, esse era desvinculado da realidade em que se inseria o trabalho do arquiteto e ignorava o contexto das mudanças sociais que se processavam nos anos 1950 (dinamismo da indústria e acesso à universidade de pessoas de menor poder aquisitivo, na visão dos autores). Devemos observar que questões como o papel da indústria e a noção de "interesses do povo" eram pontos de divergências entre Artigas e Anhaia Mello que não foram postas em questão.

Artigas foi um dos docentes a dialogar com os estudantes naquela ocasião. Seu argumento era que a discussão principal não deveria remeter ao ensino, a despeito de suas falhas. O professor defendeu que tanto o sistema de ensino como os profissionais de arquitetura eram vítimas do contexto em que se inseriam. O docente constatou, historicamente, a exígua participação dos arquitetos na construção do país, diagnosticando que isso se devia à má resolução da distinção entre construção, arquitetura e engenharia na regulamentação profissional, de modo que os arquitetos e engenheiros tornavam-se "construtores diplomados" 31 , à falta de empenho do governo paulista - "as repartições públicas estão cheias de artistas de valor fenecendo, na desimportância de sua atuação" - e à falta de espaço para cumprir sua missão inclusive no setor privado, mesmo diante do "boom imobiliário" que

31 Desde 1956 Artigas integrava a comissão do IAB que deveria propor uma nova regulamentação da profissão. A partir de então, o arquiteto passou a destinar ao menos uma parte de todos seus textos e discursos à defesa da nova regulamentação profissional (Cf. Capítulo 03). 
se processava naqueles tempos. Portanto, o problema não estava no ensino ou na distância entre a formação e a realidade profissional, mas nas condições a que estavam sujeitas esta última. A luta por um melhor ensino estava inserida no contexto mais amplo de superação do "atraso" que atingia a sociedade brasileira (GFAU, 1956, s/n).

No ano seguinte, 1957, foi criada uma comissão constituída por Artigas, Rino Levi, Abelardo de Souza e Hélio Duarte, todos docentes das cadeiras de composição da FAUUSP, com o intuito de propor modos de superar a separação entre a formação acadêmica e a vida profissional, queixa principal dos estudantes em 1956. Tal comissão traçou uma diretriz que consistia na valorização do ateliê, tornando-se esse, e não mais a Composição, a "espinha dorsal" do curso, fazendo-se convergir para ele todas as disciplinas do currículo (Relatório da Comissão apud PRADO, 1964, p. 05). A partir da diretriz de centrar o processo de aprendizado no ateliê, foi implementada uma primeira reforma, que certamente fundamentou as alterações dos programas das disciplinas a partir de então. As proporções dessa reforma, segundo a avaliação de Luiz Cintra do Prado, foram, todavia, de dimensões modestas, não passando de uma "modificação na seriação das cadeiras do currículo oficial" (idem, p. 17).

Em 1960, por ocasião do Encontro Regional de Educadores Brasileiros, realizado pelo SESI e sediado em São Paulo, a comissão responsável pela avaliação do ensino de arquitetura e urbanismo, constituída, basicamente, pelo corpo docente da FAUUSP ${ }^{32}$ reiterou a defesa da adoção do ateliê como forma de superar deficiências do ensino, em um documento intitulado "Relatório Cerqueira César" (FAGGIN, 1993, p. 131).

Em 1962, precedendo a reforma de ensino, outra comissão constituída na FAUUSP (Comissão de Estudo do Ateliê), composta pelos assistentes Carlos Millán, Jon A.V. Maitrejean, Gian Carlo Gasperini e Lúcio Grinover, apresentou um estudo e uma proposta preliminar para o Ateliể ${ }^{33}$ (idem, p. 130). A proposta da comissão visava propiciar um clima "realista" ao contexto da formação do arquiteto. Os resultados dos trabalhos dessa comissão foram sistematizados em um documento intitulado "O ateliê na formação do arquiteto".

A proposta não chegou a ser implantada institucionalmente, mas compôs as diretrizes estabelecidas pelo Departamento de Composição, explicitadas nos programas das disciplinas naquele ano. Segundo a proposta, o ateliê era composto por duas séries. A primeira ocupava os dois primeiros anos e era destinada ao "aprendizado gráfico e plástico-construtivo". A segunda ocupava os três anos restantes. Denominada "Mentalidade de Construtor. Formação do Arquiteto", desenvolvia-se em trabalhos individuais, com temas de Arquitetura, Desenho Industrial e Paisagismo, e verticais (equipe de alunos de múltiplos anos, coordenados pelo aluno de $5^{\circ}$ ano), versando sobre urbanismo, entendido como "a prática de coordenação, integração e equipamento do espaço exterior". Os trabalhos de urbanismo do

32 A comissão era constituída por Artigas, Roberto Cerqueira Cesar, Hélio Duarte, Joaquim Guedes, Carlos Millán, Lúcio Grinover, Roberto Coelho Cardozo, Luiz Roberto Carvalho Franco, Rubens Maister e Miranda Maria Martinelli Magnoli (NARUTO, 2006, p. 48). Todos eram docentes da FAUUSP.

33 Segundo Faggin, a reformulação do ensino também foi solicitada pela Reitoria da USP, durante a gestão de Ulhôa Cintra, que formulou o pedido a Lourival Gomes Machado, então diretor da FAUUSP. 
ano anterior davam as bases para a formulação dos trabalhos de projeto, desenho industrial e paisagismo daquele ano (NARUTO, 2006, p. 51). Nessa proposta, observa-se a intenção de articular os trabalhos desenvolvidos no âmbito das cadeiras de composição de arquitetura à cadeira de urbanismo ${ }^{34}$. Em 22 de dezembro de 1961 foi promulgada a Portaria $n^{\circ}$ 9, que fixava o currículo padrão dos cursos normais da FAUUSP para o ano de 1962, em que a proposta dos professores do Departamento de Composição não transpareceu, ao menos oficialmente. Entretanto, como veremos mais detalhadamente no Capítulo 04, os programas das disciplinas desse período revelaram que desde o fim dos anos 1950 procurou-se instituir essa prática, por iniciativa dos docentes das cadeiras de composição de arquitetura.

Paralelamente, o Conselho Federal de Educação vinha discutindo a fixação do currículo mínimo para diversos cursos, dentre os quais o de arquitetura. Em março de 1962, esse órgão encaminhou uma carta à Reitoria da USP, consultando-a sobre o currículo pleno dos institutos, os cursos mantidos pela instituição ou que se desejava implementar ${ }^{35}$. Em resposta à consulta realizada, o Departamento de Composição apresentou o currículo pleno para o ano de 1962, em que era possível visualizar os objetivos pretendidos com a reforma (Anexo B). A formação do arquiteto devia contemplar conteúdos técnico-científicos, histórico-sociológicos e técnico-artísticos (correspondentes às disciplinas de ateliê), que incluíam projeto de edifícios, de cidades, de desenho industrial e de comunicação visual. Enfatizava-se que a importância da nova estruturação residia no fato de que ela possibilitava ao arquiteto ter atribuições profissionais mais amplas, abrangendo os campos de comunicação visual, desenho industrial, projeto de edifícios, planejamento e paisagismo. A nova estrutura também previa a organização de cursos de pós-graduação nessas linhas de desenvolvimento didático.

Finalmente, em 1962, foi levada a cabo a reforma curricular da FAUUSP, que teve vigência a partir de 1963. Além da valorização das atividades de estúdio e a reorganização departamental, a estrutura das disciplinas foi modificada. As cadeiras de composição, as disciplinas de plástica e desenho artístico deram lugar às sequências de projeto - projeto do edifício, desenho industrial e comunicação visual. No lugar das cadeiras de urbanismo e de arquitetura da paisagem, criou-se a sequência de planejamento. A FAUUSP ficou organizada em quatro departamentos, que reuniriam, respectivamente, as disciplinas de formação Técnico-Científica (dois departamentos, de Construção e Ciências Aplicadas), Histórico-Sociológica (Departamento de História), e Técnico-Artística (Departamento de Projeto). Esse último departamento reunia todas as disciplinas vinculadas ao ateliê, compreendendo as

34 A primeira tentativa de integração das cadeiras de Composição, Urbanismo e Paisagismo se deu em 1958, em seguida à apresentação do relatório da primeira comissão de estudo, de 1957. Os registros dessa experiência foram levantados em ofícios constantes nas pastas funcionais de Rino Levi e Hélio de Queiroz Duarte. A diretoria da escola comunicava aos docentes que a comissão de ensino, "visando aprimorar os ensinamentos ministrados, aprovou experimental (sic), as aulas práticas das Cadeiras Grandes Composições (C-19), Arquitetura Paisagística (C-28) e Urbanismo (C-23), do currículo do $5^{\circ}$ ano, sejam ministradas e, conjunto a fim de se obter estreita colaboração" (apud ALBUQUERQUE, 2004, p. 359).

35 Carta de Edgard Santos, do Conselho Federal de Educação, 28/03/1962. 
sequências de projeto e de planejamento (Currículo Pleno, apud PICARELLI, 1993, p. 13). No Relatório de Atividades de 1962 afirma-se que a reestruturação curricular

Foi orientada no sentido de despertar o interesse por outros ramos da atividade profissional. Cuida-se de formar o arquiteto, imprimindo-lhe, porém, uma formação consentânea com a solicitação, cada vez mais crescente, da indústria e das necessidades sociais. O objetivo será alcançado através do desenvolvimento de quatro linhas didáticas, bem marcadas: comunicação visual (expressão gráfica), desenho industrial, arquitetura de edifícios e planejamento (FAUUSP, $1962, p . I V)^{36}$.

A reforma tinha por um de seus principais objetivos manifestos inserir a formação dos arquitetos no quadro de desenvolvimento da indústria nacional. Em um texto contemporâneo à reforma didática de 1962, por ocasião de uma premiação no $\mathrm{IAB}$, Artigas afirmou:

A fase que o Brasil atravessa em sua evolução industrial é a mais crítica e a que assume maior importância na história de nossa industrialização. É que já atravessou a produção manufatureira nacional, o período de implantação dos processos mecânicos de fabricação, para ingressar num estágio em que a técnica do fabrico e a forma plástica dos produtos têm que ser plasmado pela nossa gente. Daí, o duplo esforço que se faz necessário presentemente, para tornar efetivamente nacional os processos industriais de produção (sic) e entranhadamente brasileiros os produtos de nossas manufaturas: primeiro, o aprimoramento científico e técnico dos que trabalham no campo manufatureiro, em particular dos jovens que ingressam e ingressarão dentro em pouco nas atividades produtoras (...) e, segundo, a elaboração, para os nossos produtos, de uma forma plástica genuinamente brasileira, de modo a dar caráter próprio aos artigos que produzimos. A primeira resolve-se pela pesquisa e pelo ensino científico, a segunda pelo congraçamento de todos que labutam no campo das artes plásticas, a fim de imprimir aos nossos produtos uma forma que os caracteriza como brasileiros. (ARTIGAS, 1962/1963, grifos nossos).

36 Artigas, em 1974, reiterou a importância de uma formação que ampliasse as possibilidades de atuação do arquiteto, como forma de ampliar a sua capacidade de intervir na sociedade: "Os cursos devem padronizar o futuro arquiteto de forma mais ampla do que até hoje. Abrir as estradas para o conhecimento das várias questões permitindo ao estudante descobrir o seu mais profundo interesse, a sua maior vocação. A FAUUSP tem alguma experiência prática nesse sentido, se considerarmos que seus alunos se distribuem na ação pelos mais variados ramos das técnicas e das artes. Assim, o perfil do arquiteto deve ser o mais variado possível e baseado no mais amplo sistema de informações de maneira que possamos contar com arquitetos nos mais variados ramos da atividade social" (ARTIGAS, 1993, p. 136). 
Questões como a indústria (e a industrialização da construção) e sua nacionalização, a questão popular e dos "interesses do povo", bem como a habitação popular constituem, efetivamente, pontos de tangência entre arquitetura moderna e urbanismo e apresentam caminhos para a compreensão do que seja o urbanismo para a arquitetura. A posição de Artigas, expressa na passagem acima, é distinta da vertente carioca da arquitetura moderna e, principalmente, é um ponto de divergência entre o arquiteto e Anhaia Mello. Existindo diferenças, não foram questões debatidas. Por exemplo, enquanto Artigas defendia a industrialização da construção visando a racionalização do processo construtivo, a indústria interessava a Anhaia Mello do ponto de vista de sua descentralização e do descongestionando a capital paulista, distribuindo-a de forma equilibrada pelo território regional. Todavia, não foram encontrados registros de debates acerca dessas questões provavelmente porque, tratando-se de diferenças, foram silenciadas.

O professor Lúcio Grinover reiterou a preocupação com o desenvolvimento da indústria da construção civil:

(...) [o estudante do segundo ano da FAUUSP] começou a trabalhar com concreto armado. Então o que que ele fez? Começou a fazer escadas, começou a fazer pedaços de habitação (...) coisas desse tipo, com concreto armado, se fazia lá na FAU (...). Quer dizer, se transferiu, a um certo momento, por insistência por parte de diversos arquitetos, inclusive do nosso grupo (...) sair do ventilador e começar a fazer qualquer coisa que pudesse ser aplicada em termos industriais na arquitetura.(...) Quer dizer, uma coisa que sempre aconteceu, que o bom arquiteto sempre faz é a casa popular. Então, quando pensa em casa popular, pensa em duas coisas: ou eu faço arquitetura pré fabricada ou vai no tijolo mesmo. Tanto é que num certo momento se fez tijolo de tudo quanto era tipo lá na universidade, inclusive na faculdade (...). (Entrevista de Lúcio Grinover à autora e ao Prof. Dr. Marcos da Costa Braga, 2008)

A inserção do trabalho do arquiteto no quadro do desenvolvimento da indústria nacional, tendo em vista, especialmente, a industrialização da construção civil, foi o contexto da reforma de 1962 e um objetivo constantemente buscado pelos professores do Departamento de Projetos. Ainda assim, os objetivos foram, ao menos em parte, frustrados, em decorrência de fatores internos ${ }^{37}$ e externos, visto que o desenvolvimento da indústria da construção civil não se concretizou ${ }^{38}$.

37 Em 1981, avaliando o fracasso da tentativa de desenvolver um Desenho Industrial capaz de atender ao projeto de desenvolvimento nacional, os professores ainda se queixavam da falta de estrutura dos laboratórios, especialmente do Laboratório de Modelos e Ensaio, LAME, que não possuíam maquinário adequado para a realização deste objetivo (Relatorio de Atividades da Disciplina de Desenho Industrial, 1981).

38 A descrença na industrialização da construção como caminho para o cumprimento da função social da arquitetura foi um dos fatores que levou à formulação crítica dos antigos alunos e docentes da FAUUSP, Sérgio Ferro, Flávio Império e Rodrigo Lefèvre, no âmbito do grupo Arquitetura Nova (ARANTES, 2002). 
Em suma, podemos afirmar que as principais questões levantadas ao longo da década de 1950 e que motivaram a reforma de ensino da FAUUSP de 1962 foram: a necessidade de superar a distância entre a formação e prática profissional, o desejo de se criar uma escola de arquitetura moderna em que a questão dos "estilos" fosse superada e a confiança na industrialização da construção. Além disso, ficou manifesto o interesse em ampliar as possibilidades de atuação profissional, que devia contemplar, além do projeto do edifício, o planejamento urbano, o desenho industrial e a comunicação visual.

Artigas sem dúvida participou dos debates que resultaram na reforma curricular da FAUUSP em 1962. Sua posição de chefe do Departamento de Projeto naquela ocasião (PICARELLI, 1993, p. 12) é um indicador de sua influência nesse processo. Além disso, a autoria do projeto do edifício da faculdade na Cidade Universitária, elaborado concomitantemente às discussões e que incorporou elementos desse debate, como a valorização do estúdio, materializava, segundo seu próprio depoimento, as conclusões da reforma de ensino. Todavia, não acreditamos que se deva atribuir-lhe um papel de liderança unívoca, o que tende a suprimir a riqueza do debate coletivo que a engendrou, assim como os conflitos suscitados. A participação dos demais docentes nas comissões de ensino, com produção de documentos como o Relatório Cerqueira César e "O Ateliê na formação do Arquiteto", de Carlos Millán evidenciam a construção de um projeto coletivo.

Evitamos, assim, vincular a reforma de 1962 à criação de um paradigma que se ligaria à formação de uma "escola paulista" de arquitetura (SEGAWA, 1997, p. 146). Nosso interesse é demonstrar que essa reforma procurou institucionalizar um determinado modo de ensino, que foi construído e colocado em prática em algumas cadeiras do curso ao longo da década anterior. A fundação da FAUUSP foi marcada por contradições. Por um lado, herdou boa parte da estrutura de ensino politécnica, por outro, seus fundadores expressavam o desejo de criar uma faculdade de arquitetura moderna, o que é visível quando observamos o corpo docente que foi contratado nos primeiros anos. A reforma de 1962 foi uma tentativa de superar essa ambiguidade, conduzindo a escola para o eixo definitivo da modernidade. Entretanto, se a nova estrutura tinha como perspectiva a articulação entre arquitetura e indústria, a superação dos estilos e da composição arquitetônica e a formação de um profissional que projetasse "da caneta à cidade", na prática a proposta teve dificuldades de ser implantada, decorrente não apenas de posições divergentes na faculdade, mas também da dificuldade material da própria escola (falta de equipamentos) e, sobretudo, da não-realização, na escala nacional, da industrialização da construção. 


\section{Mudanças no corpo docente}

No Apêndice A, é possível verificar as diferentes estruturas curriculares com a relação do corpo docente responsável pelas respectivas cadeiras, conforme pudemos levantar. Nesta dissertação, procuramos reconstituir o universo de professores entre 1948 e 1962 com base nos programas das disciplinas e em uma "Relação dos docentes da FAU desde sua fundação” para os anos 1948 a 1998. Além disso, as fontes secundárias contribuíram para consolidar esse levantamento. Infelizmente, lacunas permanecem, uma vez que o cruzamento de todas as fontes consultadas não permite elaborar a correspondência precisa entre o docente e a cadeira pela qual era responsável. Ainda assim, o levantamento realizado aponta caminhos interessantes. No Apêndice C, consta uma relação do corpo docente que, de alguma forma, rompia com a tradição politécnica na FAUUSP. Analisando esse quadro, pudemos fazer algumas considerações que apresentamos a seguir.

Inicialmente, o corpo docente da faculdade foi constituído predominantemente por engenheiros da Escola Politécnica. Em todo o período analisado, foram praticamente os únicos a lecionarem nas cadeiras ditas "técnicas". A partir dos anos 1960, alguns antigos alunos egressos da própria FAUUSP, como José Ribamar da Silva e Leo Quanji Nishikawa (formados em 1954 e contratados em 1959) foram incorporados ao que viria a ser o Departamento de Tecnologia a partir de 1964. Nos primeiros anos, os professores politécnicos também eram responsáveis por disciplinas históricas, a exemplo de Bruno Simões Magro na cadeira "Arquitetura Analítica"39.

Em 1948, dos onze professores contratados para lecionar na FAUUSP, nove eram provenientes da Escola Politécnica e havia um que integrava o Instituto de Matemática e Estatística da USP, IME. O único novo docente foi Abelardo Riedy de Souza, formado na ENBA em 1932, contratado para lecionar na Cadeira de Pequenas Composições I, como assistente de Artigas (SODRÉ, 2010, p. 156). Anhaia Mello, embora fosse o diretor da FAUUSP desde sua fundação, iniciou a atividade docente na nova escola em 1949, na Cadeira de Teoria da Arquitetura, para alunos do $2^{\circ}$ ano. No mesmo ano, por indicação de Abelardo de Souza, convidou Eduardo Corona ${ }^{40}$ a ser seu assistente (CONSTANTINO, 2004, p. 56). Ainda em 1949, Hélio de Queiroz Duarte, formado na ENBA em 1930, foi contratado como professor

39 Portanto, nesse primeiro momento, perpetuava-se no campo do ensino da história a "herança politécnica" de silenciamento sobre arquitetura moderna, como se observa no depoimento do ex-aluno Jon A. V. Maitrejean: "Quem dava aula de história da arquitetura para nós era o Bruno Simões Magro, que já era velhinho, ele projetou a Igreja da Nossa Senhora do Brasil. Ele, evidentemente, não era modernista, pelo contrário. A aula dele era "História da Arquitetura", mas era uma história que nunca passava do gótico. O moderno não tinha história, a gente só estudava coisa do passado, que ninguém se interessava muito. Começava com a idéia de como tinha surgido a arquitetura, as primeiras casas, as árvores que se juntavam, amarravam, aquela coisa que era curiosa, mas muito pouco" (apud SODRÉ, 2009, p. 64).

40 Eduardo Corona (1921-2001) formou-se na Faculdade Nacional de Arquitetura em 1946. 
assistente, ocupando, no início de sua atividade docente na FAUUSP, a cadeira de Pequenas Composições. Em 1950, Alcides da Rocha Miranda (ENBA, 1932) foi contratado, a convite de Anhaia Mello, para lecionar na cadeira de Plástica.

Além dos professores politécnicos, o corpo docente da FAUUSP entre 1948 e 1962 foi sendo constituído, inicialmente, por antigos alunos do curso de engenheiros arquitetos da Escola Politécnica que, sobretudo desde os anos 1940, estavam envolvidos com a institucionalização do campo profissional e com a defesa da arquitetura moderna. Dentre eles, além de Artigas, estavam Zenon Lotufo, Roberto Cerqueira Cesar, Ernest Robert de Carvalho Mange, Ícaro de Castro Mello, Oswaldo Corrêa Gonçalves. Alguns arquitetos modernos formados no Rio de Janeiro também vieram compor o quadro de professores da faculdade nos primeiros anos, conforme acabamos de mencionar. A partir de 1954, os ex-alunos da própria FAUUSP passaram a ser incorporados no corpo docente ${ }^{41}$. Além disso, devemos chamar a atenção para a contratação de arquitetos formados na nova faculdade de arquitetura do Mackenzie, criada em 1947. Dentre eles, Luiz Roberto de Carvalho Franco, Carlos Millán e Paulo Archias Mendes da Rocha, este contratado como assistente de Artigas em 1960.

Durante o período analisado, apenas em 1951 não foram contratados profissionais ligados à defesa da arquitetura moderna. Nesse ano, foi recusada a contratação de Oscar Niemeyer pela Reitoria da USP, o que desencadeou uma greve dos estudantes da FAUUSP de quatro meses de duração ${ }^{42}$. Anhaia Mello, que ocupava diversos cargos dentro da universidade, incluindo o de diretor da FAUUSP, exonerou-se de todos eles. Foram contratados os arquitetos Elisário da Cunha Bahiana e José Vicente Vicari para reger, respectivamente, as cadeiras de Grandes Composições I e II (Cadeiras n 18 e 19), destoando da tendência de formação de um quadro docente moderno. Além disso, foram contratados no mesmo ano os docentes Archimedes Dutra ${ }^{43}$ e Alfredo Oliani ${ }^{44}$ para as cadeiras de Desenho Artístico e Plástica IV.

41 O primeiro ex-aluno contratado como professor na FAUUSP foi Jon A.V. Maitrejean, em 1954. Ao todo, entre 1954 e 1962, dos sessenta e cinco docentes contratados, vinte eram antigos alunos. Essa tendência foi reforçada nos últimos anos do período analisado, perpetuando-se daí em diante. Em 1962 foram contratados dezesseis novos professores, dos quais doze haviam se formado na própria FAUUSP.

42 Essa greve teve grande repercussão nos jornais e na universidade, o que é reiterado pelos antigos estudantes da faculdade. Ressaltamos o depoimento de Nestor Goulart Reis Filho a Sodré (2009), segundo o qual a recusa de Oscar Niemeyer para ocupar a cadeira de Grandes Composições do $5^{\circ}$ ano, sob o pretexto de este integrar o PCB, e a descontratação de Colette Pujol, filha do engenheiro arquiteto da Escola Politécnica Hypolito Pujol foi mobilizada por iniciativa de Zeferino Vaz junto ao Conselho Universitário, como uma afronta pessoal a Anhaia Mello. Foi o que desencadeou sua renúncia a todos os cargos dirigentes, inclusive o de vice-reitor, que ocupava naquele momento (REIS FILHO apud SODRÉ, 2009, p. 107-108).

43 Archimedes Dutra, escultor e pintor (sobretudo paisagista) estudou na Academia de Belas Artes de Roma em 1947 após uma trajetória artística de longa data.

44 Alfredo Oliani foi um escultor de obras tumulares que frequentou a Escola Nacional de Belas Artes de São Paulo e a Academia de Belas Artes de Florença. 
De modo geral, as cadeiras de "Plástica", "Desenho Artístico" e "Composição Decorativa" foram ocupadas, nos primeiros anos da FAUUSP, por professores ligados à arte atuantes na própria Escola Politécnica, como Felisberto Ranzini e Caetano Fraccaroli ou então outros artistas formados no âmbito das Belas Artes. Entre 1949 e 1952, foram contratados, além dos já mencionados, Vera Helena do Amaral, que trabalhou na FAUUSP entre 1949 e 1962, Bassano Vaccarini, entre 1952 e 1956, e Vicente Larocca, entre 1952 e 1954. Nesse primeiro momento, a única situação que diferia desse padrão foi a contratação de Alcides da Rocha Miranda. Como é possível notar, nenhum desses docentes permaneceu na FAUUSP depois de 1962. A situação começou a modificar-se a partir de 1956, quando a maior parte dos professores contratados para lecionar nessas cadeiras foi constituída por alunos egressos da FAUUSP. Entre 1956 e 1962, foram contratados Luiz Gastão de Castro Lima (FAUUSP, 1954), Miranda Maglioli (FAUUSP, 1955), Lúcio Grinover (FAUUSP, 1957) e Abrahão Velvu Sanovicz (FAUUSP, 1958) ${ }^{45}$. Todos eles desempenharam um importante papel na reforma de ensino de 1962. A partir da reestruturação curricular, esses docentes ficaram a cargo das disciplinas pertencentes às Sequências de Desenho Industrial e Comunicação Visual.

Além dos arquitetos, é importante citar a contratação de docentes como Lourival Gomes Machado (1952), Flávio L. Motta (1954) e Juarez Brandão Lopes (1954), todos da Faculdade de Filosofia, Ciências e Letras, FFCL, que no âmbito da história e dos fundamentos sociais da arquitetura, fortaleceram a defesa da arquitetura moderna em São Paulo e contribuíram para a adoção dessa orientação na FAUUSP.

Diante do que acabamos de apresentar, ponderamos que, embora inicialmente tenha sido feito um esforço para trazer para a nova faculdade uma perspectiva moderna para a arquitetura, com a contratação de alguns profissionais ligados à arquitetura moderna formados no Rio de Janeiro, foi entre 1954 e 1956 que parece ter ocorrido uma "virada" em direção à consolidação da FAUUSP como uma escola de arquitetura moderna. Os indícios que nos levam a essa hipótese são, especialmente, a mudança no padrão dos docentes contratados para as cadeiras de Plástica, Desenho Artístico e Composição Decorativa ${ }^{46}$ e a contratação de antigos alunos da FAUUSP a partir de $1954^{47}$. Além disso, observaremos adiante as transformações nas disciplinas de Composição que reforçam essa hipótese.

45 Luiz Gastão de Castro Lima, Abrahão V. Sanovicz e Jacob Ruchti foram assistentes de José Maria da Silva Neves na cadeira de Composição Decorativa. Com exceção de Ruchti, que deixou a FAUUSP em 1962, todos os docentes, incluindo o politécnico, passaram a lecionar na Sequencia de Desenho Industrial do Departamento de Projeto.

46 As mudanças que se processaram nessas disciplinas ao longo dos anos 1950, a partir da contratação de antigos alunos da FAUUSP, consolidadas na reforma de 1962, ficam bem caracterizadas com o depoimento de Élide Monzéglio a respeito do antigo docente da Escola Politécnica: “[Desde a reforma de 1962, Caetano] Fraccaroli estava "meio defasado" em relação a esse grupo de professores e "não se integrava com a característica do Design Gráfico (...)”. A partir de então, Fraccaroli, deixou de dar aulas formalmente. "Ele era professor do Departamento de Projeto, não dava mais aula porque não se engrenava com o sistema”. (MALERONKA, 2000, p. 21)

47 A importância da participação dos antigos alunos na modernização do curso da FAUUSP foi assinalada por Sodré (2010, p.16). 
A fundação da FAUUSP significava um passo em direção à autonomia do campo profissional, posto que se separava da escola de engenharia. Todavia, mesmo depois de criada a faculdade, a conquista dessa autonomia não se processou automaticamente. Vários são os indícios da situação de subordinação aos interesses da faculdade à Escola Politécnica e ao Conselho Universitário da USP. Apesar da contratação dos profissionais mencionados acima, esse corpo docente teve de conviver com uma predominância de professores catedráticos da Escola Politécnica. A própria recusa em contratar Oscar Niemeyer em 1951 revelou os limites com que os interessados na criação de uma faculdade de arquitetura moderna se deparavam. A contratação de docentes mediante concurso foi possível apenas após a instituição do regulamento da faculdade, a partir de 1955. Ainda assim, até 1968, devido ao número insuficiente de professores catedráticos, a faculdade não possuía uma congregação própria, de forma que as funções de congregação eram exercidas no âmbito do Conselho Universitário da USP. Também por isso, até 1961, todos os diretores da FAUUSP eram politécnicos ${ }^{48}$. Finalmente, em 1961, Lourival Gomes Machado, catedrático da FFCL foi nomeado diretor da FAUUSP em substituição a Anhaia Mello, que se aposentara, muito devido à movimentação de um grupo de docentes da FAUUSP contra a escolha de um novo engenheiro politécnico como diretor (ARTIGAS, 1961). Esse embate é um indicativo dos esforços que foram feitos para ganhar autonomia face à engenharia, mesmo após a separação formal.

Apesar dos conflitos existentes, a arquitetura moderna ganhou um espaço de defesa desde os primeiros anos de funcionamento da nova faculdade, como se observa no testemunho de Maitrejean, discente formado em 1953:

É uma coisa engraçada, você entrava na FAU, não sabia nada de arquitetura, nem de coisa nenhuma, mas em poucos meses você estava tão escolado que você virava realmente um fanático defensor da arquitetura moderna (apud SODRÉ, 2009, p. 64).

O depoimento de Gustavo Neves da Rocha Filho também revela a hegemonia da vertente da arquitetura moderna na faculdade:

(...) esses professores [arquitetos, como Artigas, Zenon Lotufo, Hélio Duarte, Eduardo Corona, Ícaro de Castro Mello, Oswaldo Corrêa Gonçalves, Rino Levi e outros] detonaram o interesse que a gente poderia ter por arquitetura tradicional (idem, p. 52).

Esses professores exerceram grande influência nos estudantes, entusiasmando-os com a profissão de arquitetura.

48 Em ordem, os primeiros diretores da FAUUSP foram: Anhaia Mello (1948-1951); Bruno Simoes Magro (1951-1952); Luiz Cintra do Prado (1953-1954); Lysandro Melo Pereira da Silva (19541956); Pedro Bento Jose Gravina (1956-1959); e Anhaia Mello (1959-1961). O primeiro diretor arquiteto e catedrático da FAUUSP foi o professor Nestor Goulart Reis Filhos, que tomou posse apenas em 1972, permanecendo no cargo até 1976. 
No Apêndice D, apresentamos uma análise do corpo docente que lecionou nas cadeiras de composição de arquitetura na FAUUSP, conforme pudemos levantar. Em síntese, trata-se dos profissionais relacionados a seguir:

Tabela 1 - Corpo Docente de Composição da FAUUSP (1948-1962)

\begin{tabular}{|c|c|c|c|}
\hline Cadeira & Docente & Período & Obs. \\
\hline \multirow{8}{*}{$\begin{array}{l}\text { Cadeira I6 } \\
I^{\circ} \text { ano }\end{array}$} & Artigas & I948 & \\
\hline & Abelardo de Souza & I948 & Assistente \\
\hline & Zenon Lotufo & I949-I957 & \\
\hline & Hélio de Queiroz Duarte & I949 & Assistente \\
\hline & Oswaldo Corrêa Gonçalves * & I954-I955 & Assistente \\
\hline & Ícaro de Castro Mello* & $\mathrm{I} 955$ & \\
\hline & Artigas & I956-I957 & Assistente \\
\hline & Hélio de Queiroz Duarte & $1958-1962$ & \\
\hline \multirow{4}{*}{$\begin{array}{l}\text { Cadeira } 16 \\
2^{\circ} \text { ano }\end{array}$} & Artigas*** & I949-I95I/ I949-I953? & \\
\hline & Abelardo de Souza ${ }^{* * *}$ & I949-I953? & Assistente \\
\hline & Hélio de Queiroz Duarte & I955/1955-1962? & \\
\hline & Plínio Croce & $1955^{*}$ & Assistente \\
\hline \multirow{6}{*}{$\begin{array}{l}\text { Cadeira } 17 \\
3^{\circ} \text { ano }\end{array}$} & Hélio de Queiroz Duarte & I950-I953 & \\
\hline & Ernest Robert de Carvalho Mange & I950-I953 & Assistente \\
\hline & Ícaro de Castro Mello & $\mathrm{I} 954$ & \\
\hline & Plínio Croce & I954 & \\
\hline & Abelardo de Souza & $1955-1962$ & \\
\hline & Jon A.V. Maitrejean & $1955-1962$ & Assistente \\
\hline \multirow{12}{*}{$\begin{array}{l}\text { Cadeira I8 } \\
4^{\circ} \text { ano }\end{array}$} & José Vicente Vicari & I950-I953 & \\
\hline & Hélio de Queiroz Duarte & I953 & \\
\hline & Ícaro de Castro Mello & I954 & \\
\hline & Oswaldo Corrêa Gonçalves & I954 & Assistente \\
\hline & Plínio Croce? & I954 & \\
\hline & Zenon Lotufo? & 1955 & \\
\hline & Hélio de Queiroz Duarte? & $\mathrm{I} 955$ & \\
\hline & Ernest Robert de Carvalho Mange? & I955 & Assistente \\
\hline & Hélio de Queiroz Duarte & I957 & \\
\hline & Roberto Cerqueira César & $1958-1962$ & \\
\hline & Luiz Roberto de Carvalho Franco & $1958-1962$ & Assistente \\
\hline & Carlos Barjas Millán & I959-1962 & Assistente \\
\hline \multirow{6}{*}{$\begin{array}{l}\text { Cadeira } 19 \\
5^{\circ} \text { ano }\end{array}$} & Elisário da Cunha Bahiana & I952-1953 & \\
\hline & Rino Levi & I954-I959 & \\
\hline & Roberto Cerqueira César & I955-I957 & Assistente \\
\hline & Artigas & I958-1959 & Assistente \\
\hline & Artigas & $1960-1962$ & \\
\hline & Paulo A. Mendes da Rocha & $1960-1962$ & Assistente \\
\hline
\end{tabular}

* Dados não precisos

** Dúvidas sobre a presença de Artigas na FAUUSP entre 1952 e 1955 
De modo geral, o corpo docente de composição reunia profissionais comprometidos com a arquitetura moderna. Chama a atenção a relação de trabalho entre esses arquitetos fora da FAUUSP e mesmo antes da sua fundação. Em 1945, Rino Levi constituiu o Rino Levi Arquitetos Associados Ltda. com Roberto Cerqueira César e, posteriormente, com Luiz Roberto Carvalho Franco, que também integraria o corpo docente da FAUUSP. Entre 1946 e 1949, Abelardo Riedy de Souza, Hélio Duarte e Zenon Lotufo associaram-se em um escritório, desenvolvendo diversos projetos em sociedade. Também houve parcerias entre Oswaldo Corrêa Gonçalves e Ícaro de Castro Mello. O Convênio Escolar, dirigido por Hélio de Queiroz Duarte, contou com a colaboração de Oswaldo Corrêa Gonçalves, Roberto Tibau, Ernest Robert de Carvalho Mange e Eduardo Corona, todos docentes da FAUUSP, ao menos por um breve período. Artigas, que não desenvolveu parcerias deste tipo com seus colegas de docência, de toda forma esteve próximo a todos eles e outros mais, que também viriam a lecionar na FAUUSP, no âmbito de outro importante espaço de fortalecimento institucional: o departamento paulista do Instituto de Arquitetos do Brasil, de cuja fundação todos eles participaram. 


\title{
CAPÍTULO 2
}

\author{
0 Papel de Anhaia Mello na \\ criação da FAUUSP
}




\section{A inserção de Anhaia Mello na Escola Politécnica}

Luiz Ignácio Romeiro de Anhaia Mello (1891-1974), filho do Engenheiro Luiz de Anhaia Mello (1854-1899), industrial e um dos fundadores da Escola Politécnica, ingressou no curso de engenheiros arquitetos daquela escola em 1909, formando-se em 1913. Em seguida, foi trabalhar no escritório do arquiteto Ramos de Azevedo, grande amigo de seu pai. Dirigiu a Iniciadora Predial, até sua dissolução em 1964, e a Cia. Cerâmica Villa Prudente, ambas do ilustre arquiteto.

Ingressou como lente substituto da seção de arquitetura da Escola Politécnica em 1918 e foi promovido a catedrático de "Estética. Composição Geral e Urbanismo - 1ª $2^{\text {a }}$ Partes” em 1926. Dirigiu essa cadeira até a extinção do curso de engenheiros arquitetos, em 1954, quando passou a dirigir a cadeira de "Noções de Arquitetura e Construções Civis. Higiene das Habitações - $1^{\mathrm{a}}$ e $2^{\mathrm{a}}$ partes”, que ministrava disciplinas a outros cursos da escola. Contudo, em sua trajetória, foi o urbanismo, e não a arquitetura, a disciplina que priorizou estudar, ensinar e divulgar nos meios especializados.

Embora seja o fundador e primeiro diretor da Faculdade de Arquitetura e Urbanismo da USP, a contribuição de Anhaia Mello para a arquitetura em São Paulo não foi ainda objeto de estudos acadêmicos, tendo-se privilegiado suas contribuições para o urbanismo. Enunciações como as apresentadas em Ficher (2005), apoiada em depoimentos de seus alunos na Escola Politécnica, de que Anhaia Mello se dedicou pouco à arquitetura ou que tinha certo desinteresse pela arquitetura em face do urbanismo, vêm reforçar essa ideia. Todavia, apesar de ter priorizado o urbanismo em sua trajetória profissional, sua atuação influenciou profundamente a formação do campo de arquitetura em São Paulo. Como representante da administração pública, como fundador e diretor da FAUUSP e mesmo compondo a direção do IAB-SP, Anhaia Mello participou ativamente das instituições, processos e debates que contribuíram para a formação do campo profissional de arquitetura em São Paulo. Em sua luta em defesa de um determinado urbanismo, que rompia com a tradição ligada à engenharia municipal e à Escola Politécnica, Anhaia Mello construiu uma sólida aliança com os arquitetos modernos em São Paulo, ainda que suas posições nem sempre fossem coincidentes. Na docência, Anhaia Mello é lembrado por seus antigos alunos como um dos poucos a aceitarem a arquitetura moderna, não impondo a obrigatoriedade de seguir estilos arquitetônicos em seus trabalhos. Em 1929, durante a visita de Le Corbusier a São Paulo, o arquiteto franco-suíço foi recebido no Instituto de Engenharia, IE, de que Anhaia Mello era então presidente, e foi lá que professou suas palestras sobre arquitetura moderna e sobre urbanismo (LIRA, 2005, p. 07). Sem ter sido repudiado pelo IAB, como ocorreu com os defensores da arquitetura acadêmica, sem ter desenvolvido a linguagem e o discurso da arquitetura moderna paulista, houve uma aliança entre os arquitetos modernos de São Paulo e Anhaia Mello que permanece inexplorada.

Anhaia Mello ocupou, em diversas ocasiões, cargos dirigentes em instituições de ensino ou de classe. Em 1927, foi o diretor pedagógico das Escolas Profissionais do Liceu de Artes e Ofícios de São Paulo. Em 1928, foi vice-diretor da Escola Politécnica (Decreto 
de 19/07/1928). Entre 1 de novembro e 18 de dezembro de 1930, foi designado diretor da Escola pelo Governo Provisório. Em 1941, foi nomeado diretor da Faculdade de Filosofia, Ciências e Letras. Além disso, dirigiu a FAUUSP entre 1948 e 1951 e entre 1959 e 1961, ano de sua aposentadoria. Entre março de 1950 e abril de 1951 ocupou o cargo de vice-reitor da USP. Em 1951, Anhaia Mello requereu sua exoneração de todos os cargos dirigentes que ocupava na Universidade de São Paulo: de diretor da FAUUSP, de Presidente e membro da Comissão de Estudos da Cidade Universitária e de vice-reitor ${ }^{1}$. Foi membro da Comissão Orientadora do Plano Diretor do município de São Paulo a partir de 1953. Anhaia Mello foi um dos fundadores da Sociedade Amigos da Cidade em 1934 e foi seu presidente em 1948. Foi também presidente do Instituto de Engenharia em 1930. Em 1961, era vice-presidente da União Internacional de Arquitetos, UIA. Na administração pública, foi vereador em 1920, prefeito em 1930 e 1931 (por breves períodos) e Secretário de Estado dos Negócios da Viação e Obras Públicas em 1941.

Quando se aposentou, em 1961, Anhaia Mello era o decano da Escola Politécnica. Foi homenageado com os títulos de Professor Emérito da Escola Politécnica e de Doutor Honoris Causa da Universidade de São Paulo (Ofício nº D-1780/61 da Escola Politécnica) ${ }^{2}$. $\mathrm{Na}$ Assembleia Legislativa, por proposta do Deputado Estadual Juvenal Rodrigues de Moraes, recebeu um voto de homenagem "pelo muito que vem dando à cultura e pela soma enorme de serviços seus que beneficiaram o Estado de São Paulo" (Requerimento ${ }^{\circ} 875$ de 1961, aprovado em sessão de 12 de agosto de 1961).

1 Sua exoneração foi motivada por um incidente relativo ao concurso para contratação de um professor para o curso de Desenho Artístico para alunos do $2^{\circ}$ ano da FAUUSP. Segundo consta no Diário Oficial de 22 de junho de 1951, em 1950 três candidatos haviam apresentado a comprovação de títulos para concorrer à vaga: Colette Pujol, Archimedes Dutra e Miguel Badra Junior. Em maio de 1950 a Comissão de Ensino e Regimentos definiu que Colette Pujol deveria assumir o cargo e, seis meses depois, após a contratação da mesma, foi revisto o parecer decidindo-se por Archimedes Dutra. Anhaia Mello em novembro de 1950 solicitara ao Conselho Universitário sua exoneração do cargo de diretor da FAUUSP, considerando que não poderia transmitir ao candidato escolhido em primeiro lugar a notícia da mudança de posição do Conselho Universitário, avaliando que se tratava de um desprestígio ao diretor da FAUUSP. Não tendo sido aceito o seu pedido de demissão, este foi renovado na sessão de 28 de março de 1951, reiterando que se sentia desautorizado na faculdade que dirigia. O impasse chegou à Assembleia Legislativa, com acusações contra Anhaia Mello feitas pelo deputado Valentim Amaral, o que levou também à manifestação do IAB (assinada por Oswaldo Bratke) e da Congregação da Escola Politécnica, em favor de Anhaia Mello, bem como de uma intervenção do deputado Lincoln Feliciano na 410 sessão da Assembleia Legislativa, publicada no DOSP em 22/06/1951 (p. 36-39). O professor da FAUUSP Nestor Goulart Reis Filho afirmou que além do incidente referente a esse concurso, sua demissão também foi motivada pela recusa da Reitoria da USP em contratar o arquiteto Oscar Niemeyer para lecionar na FAUUSP sob o pretexto de tratar-se de um comunista (apud SODRÉ, 2009, p. 107).

2 Ao se aposentar, Anhaia Mello ocupava o cargo de diretor da FAUUSP. A pedido de um grupo de professores da faculdade, foi verificada a possibilidade de permanecer na direção após sua aposentadoria, o que não foi aceito pelo Conselho Universitário. Foi então votada uma lista tríplice para a eleição do novo diretor, tendo, afinal, sido escolhido Lourival Gomes Machado, da FFCL. 
Para compreender o papel de Anhaia Mello na fundação da FAUUSP e a forma como isso se processou no seio da Escola Politécnica, é preciso, antes, trazer alguns elementos acerca da estruturação do curso de engenheiros arquitetos, observando o lugar ocupado pelo docente. Em função desse lugar, o engenheiro foi levado a responder em nome da escola pelos assuntos de arquitetura e de urbanismo.

No contexto de industrialização e de crescimento pelo qual a cidade de São Paulo passava em fins do século XIX, um grupo de engenheiros foi motivado a criar a Escola Politécnica em 1893, primeira instituição de ensino superior voltada para as ciências exatas da capital paulista. Os cursos da Escola Politécnica eram lecionados por professores catedráticos, que contavam com a colaboração de professores assistentes ou adjuntos, responsáveis por ministrar conteúdos específicos relativos às respectivas cadeiras. Havia também professores de aula, que lecionavam matérias que não se inseriam nas cátedras. Em 1894, um ano após a fundação da escola, o seu segundo regulamento previu a criação do curso de engenheiros arquitetos. Esse era um dos menores cursos dentre os oferecidos. Com periodicidade irregular, formou, ao longo de seus sessenta anos de funcionamento (1894-1954), um total de 109 profissionais. Diferentemente do curso de arquitetura do Rio de Janeiro ${ }^{3}$, vinculado à tradição de Belas Artes, em São Paulo, a arquitetura veio a ser ensinada como especialidade da engenharia. Nas palavras de Anhaia Mello, naquele tempo,

(...) andava a Arquitetura divorciada da Construção; era interpretada em termos de massa e espaço e o ensino se baseava em dados predominantemente estéticos e não de função e estrutura, o que parecia caber melhor numa politécnica (apud LEMOS, 1993, p. 44).

Sendo ensinada como uma especialidade da engenharia, a formação em arquitetura em São Paulo habilitava os egressos a projetar e construir edifícios, atividade análoga à dos engenheiros civis, que deveriam projetar e construir obras de engenharia -pontes, viadutos, etc. ${ }^{4}$ (FICHER, 2005, p. 26). Dessa forma, os cursos de engenheiros civis e de en-

3 O curso de arquitetura era oferecido no Rio de Janeiro pela Escola Nacional de Belas Artes. A origem da escola está na Academia Real de Belas Artes, inaugurada em 1816. De acordo com Uzeda (2010), essa foi a primeira instituição dedicada ao ensino de artes no Brasil. A escola reunia os cursos de pintura, escultura, gravura e arquitetura.

4 O foco da formação sobre a atividade de construção relaciona-se com o contexto de atuação dos profissionais naquele momento. Conforme assinalado por Silva (2010) até por volta dos anos 1940 os mesmos profissionais se encarregavam das atividades de concepção do projeto e execução da obra e, por vezes, até mesmo as atividades de incorporação imobiliária. Neste processo, alguns arquitetos como Rino Levi, Oswaldo Bratke, Artigas, Eduardo Kneese de Mello, dentre outros, abandonaram as demais atividades dedicando-se exclusivamente ao projeto de arquitetura tão logo quanto puderam, ao passo que outros, como Ícaro de Castro Mello, Gregori Warchavchik, Franz Heep, Daniele Calabi e Jacques Pilon mantiveram, além de seus escritórios de arquitetura, empresas construtoras e imobiliárias (SILVA, 2010, p. 90). A primeira regulamentação da 
genheiros arquitetos partilhavam a maior parte das cadeiras e aulas. Comparando as grades curriculares dos dois cursos ao longo do tempo, observa-se que os conteúdos específicos do curso de engenheiros arquitetos estavam no âmbito das cadeiras de História da Arquitetura e História da Arte, de Composição Geral e das aulas de Desenho de Perspectiva ${ }^{5}$.

Durante a Primeira República, Ramos de Azevedo, que era um dos mais influentes arquitetos de São Paulo, foi o principal docente do curso de engenheiros arquitetos da Escola Politécnica. Formou-se em 1878 na École Spéciale de Génie Civil et des Arts et Manufactures pela Universidade de Gand, na Bélgica. Originário de uma família campineira, amigo do General Francisco Glicério, Ramos de Azevedo filiou-se ao Partido Republicano Paulista, PRP, sendo suplente de senador em 1900 e $1903^{6}$. Apesar de jovem e pertencente ao grupo político republicano, Ramos de Azevedo foi o escolhido pelo presidente da província, o Conde de Parnaíba, em 1886, para projetar para a Coroa o edifício da Tesouraria da Fazenda (LEMOS, 1993, p. 21). Desde então, Ramos de Azevedo passou a construir um percurso profissional em que foi consagrado como arquiteto oficial, projetando e construindo um grande número de edifícios públicos na capital paulista, além de palacetes para a elite. Coerentemente com a forma de produção arquitetônica naquele momento, o escritório de Ramos de Azevedo nunca projetou para que outros construíssem, tendo, entretanto, construído projetos de terceiros (idem, p. 43). Chegou a constituir uma rede empresarial gerenciada por amigos ou parentes, dominando todos os setores da construção civil, desde a questão fundiária (revenda de terrenos), financiamento das obras, projeto, construção, importação/ fabricação de materiais, etc ${ }^{7}$.

4 profissão de arquiteto, em nível federal, data, como vimos, de 1933, regulamentando também o exercício da engenharia e da agrimensura. Até então, as atividades de arquitetos, engenheiros, mestres de obras e construtores diferenciavam-se pouco. Entretanto, é importante considerar que a definição das atribuições do campo de arquitetura e sua relação de autonomia ou dependência com relação à engenharia não era consensual. Por um lado, Christiano Stockler das Neves em 1923 já defendia a necessidade de separação entre as atividades de projetar (âmbito da arquitetura) e de construir (âmbito da engenharia), enquanto, por outro, profissionais ligados ao Instituto de Engenharia e à Sociedade dos Arquitetos e Engenheiros, majoritariamente membros da Escola Politécnica, defendiam a arquitetura como uma especialidade da engenharia, de modo que projeto e obra pertenciam ao mesmo campo profissional (idem, p. 85).

5 Ficher (2005) analisou as transformações na estrutura curricular do curso de engenheiros arquitetos da Poli com base nos sucessivos regulamentos da escola, comparando as cadeiras dos cursos de engenheiros arquitetos e de engenheiros civis, constatando a semelhança entre eles. Partindo dessa análise comparativa, pudemos concluir que os conteúdos específicos do curso de arquitetura na escola eram os apontados acima.

6 Informação disponível em http://www.al.sp.gov.br/acervo-historico/base-de-dados/republica-velha/repvelha_senado_paulista.html (acesso em 07/10/2013).

7 O principal escritório de Ramos de Azevedo era o Escritório Técnico F.P. Ramos de Azevedo, também chamado de Ramos de Azevedo e Cia. Após sua morte, a empresa passou a chamar-se Escritório Técnico F. P. Ramos de Azevedo - Severo Villares e Cia Ltda. Essa chegou a ser a mais importante construtora de São Paulo. Além disso, Ramos de Azevedo fundou, em 1910 a Companhia Cerâmica Vila Prudente, fábrica de objetos cerâmicos, principalmente de tijolos. Em 1911, fundou o Banco Ítalo Belga, com Francisco Ferreira Ramos, Hermelindo Matarazzo, 
Nos primeiros anos de funcionamento da Escola Politécnica, Ramos de Azevedo foi responsável pelo ensino dos conteúdos relativos ao desenho ${ }^{8}$, à construção ${ }^{9}$, à história ${ }^{10}$ e à composição arquitetônica ${ }^{11}$. Ramos de Azevedo também era o arquiteto responsável pelas instalações da Escola Politécnica: dirigiu as obras de adaptação do Solar do Marquês de Três Rios para a sua instalação em 1894 e, entre 1895 e 1898, projetou e construiu o Edifício Paula Souza para abrigar atividades da Escola.

Ramos de Azevedo lecionou na Escola Politécnica até sua morte, em 1928. Até 1917, seus principais substitutos foram Maximiliano Emilio Hehl e Georg Krug. Em 1916, com o falecimento de Hehl, foi aberto o concurso para lente substituto da IV Seção de Artes da Escola Politécnica ${ }^{12}$, de arquitetura. Dos quatro candidatos inscritos, apenas os três egressos da Escola Politécnica realizaram o concurso, obtendo a seguinte colocação: em primeiro lugar, Alexandre Albuquerque (1880-1940), formado em 1905, ingressou como docente em 1917; Anhaia Mello obteve o segundo lugar, contratado em 1918; e Bruno Simões Magro (1882-1956), formado em 1905, ficou em terceiro, assumindo o cargo em

7 Antonio Carlos da Silva Telles, Eugenio Terroir, Felix Delaborde, dentre outros. Em 1913, fundou a Cia. Suburbana Paulista, que visava urbanizar uma área entre o Instituto Butantã e Osasco, com lotes residenciais, chácaras e glebas industriais. Antes de 1920, fundou, ainda, a Serraria Azevedo Miranda. Também criou, com Ataliba Oliveira Vale e José Antonio da Fonseca Rodrigues, um escritório de engenharia para construir obras públicas no interior de São Paulo (LEMOS, 1993, p. 77). Além disso, inaugurou em 1908, com Ricardo Severo, Frederico Vergueiro Steidel e Arnaldo Vieira Carvalho a Cia. Iniciadora Predial, voltada para atividades de financiamento imobiliário, que construía residências de aluguel e financiava a construção de residências particulares (SILVA, 2006, p. 84).

8 Ramos de Azevedo lecionou nas cadeiras de Desenho Geométrico e Perspectiva.

9 Por ensino de "construção", nos referimos à cadeira de "Noções de Arquitetura e Construções Civis. Higiene das Habitações” (nomenclatura de 1925), curso seguido por engenheiros arquitetos e engenheiros civis. No $2^{\circ}$ Regulamento da Escola Politécnica, a cadeira tinha o nome de "Arquitetura Civil. Higiene das Habitações".

10 As cadeiras de história também passaram por sucessivas reformulações, até que, no $10^{\circ}$ regulamento, de 1935, seu conteúdo foi reunido com o de "Noções de Arquitetura e Construções Civis. Higiene das Habitações", ficando a cadeira com o nome de "Noções de Arquitetura e Construções Civis. Higiene das Habitações. História da Arquitetura”.

11 Assim como as demais cadeiras, passou por sucessivas reestruturações, desdobramentos e reuniões, até que em 1925, o conteúdo de Composição Geral foi reunido em uma única cadeira que tratava também da Estética e do Urbanismo, sob o nome de "Estética. Composição Geral e Urbanismo - $1^{\mathrm{a}}$ e $2^{\mathrm{a}}$ Partes”. O ensino de urbanismo foi previsto apenas no regulamento de 1925. Antes disso, o regulamento de 1918 previa uma cadeira de Arquitetura de Cidades, extinta em 1925, ministrada por Bruno Simões Magro (FICHER, 2005, p. 115).

12 A IV Seção da Escola Politécnica reunia as cadeiras de: Geometria Descritiva, Aplicações de Geometria Descritiva, Geometria Projetiva, Composição Geral - $1^{\text {a }}$ Parte (habitações), Composição Geral - $2^{\mathrm{a}}$ Parte (edifícios públicos) e História da Arquitetura, Estética, Estilos $-1^{\mathrm{a}}$ e $2^{\mathrm{a}}$ Partes, conforme Regulamento de 12 de junho de 1918. 
1921. Em 1926, após um período em que foram substitutos, principalmente, de Ramos de Azevedo, Anhaia Mello e Alexandre Albuquerque tornaram-se catedráticos, respectivamente, de "Estética. Composição Geral e Urbanismo - $1^{\text {a }}$ e $2^{\mathrm{a}}$ Partes"13 e "História da Arquitetura" ${ }^{14}$, tendo Bruno Simões Magro por substituto. Quando Ramos de Azevedo deixou a Escola Politécnica, Alexandre Albuquerque assumiu, cumulativamente, a cadeira de "Noções de Arquitetura e Construções Civis. Higiene das Habitações”. Alexandre Albuquerque deixou a Escola Politécnica em 1939. Em 1942, Bruno Simões Magro tornou-se o catedrático, tendo como assistentes: Ernesto Sampaio de Freitas (até 1945), Zenon Lotufo (19441945) e Ariosto Mila (a partir de 1946).

Anhaia Mello, que dirigiu a cadeira de "Estética. Composição Geral e Urbanismo $1^{\mathrm{a}}$ e $2^{\mathrm{a}}$ Partes" até sua extinção em 1954, teve, ao longo desse período, diversos assistentes, a saber: José Maria da Silva Neves (1934-1937); Zenon Lotufo (1938; 1940; 1947) ${ }^{15}$; Afonso Iervolino (1939); Artigas (1940 a 1952) e Ariosto Mila (1941-1942). Como é possível observar, Artigas foi o seu assistente por mais tempo, auxiliando o catedrático no ensino por um período de 12 anos.

Em suma, a partir de 1926, Anhaia Mello, foi o professor da única cátedra exclusivamente voltada para os engenheiros arquitetos. Todavia, há diferenças significativas entre a posição ocupada por Ramos de Azevedo no meio arquitetônico de sua época e aquela ocupada por Anhaia Mello. É significativo que Anhaia Mello tenha se tornado catedrático justamente quando o ensino do urbanismo foi incluído na grade curricular do curso de engenheiros arquitetos, sob sua responsabilidade. Pouco tempo depois, o docente se consagrarou como um dos mais importantes especialistas no assunto, quando apresentou um ciclo de conferências no Instituto de Engenharia que sistematizavam suas posições acerca da disciplina, entre 1928 e 1929.

A análise dos documentos contidos na Pasta Funcional de Anhaia Mello na Escola Politécnica, assim como das Atas de Congregação daquela escola revelaram que, já nos anos 1930, aquele docente era chamado a responder pelos assuntos relativos à arquitetura, ao urbanismo e à institucionalização do campo profissional como representante da Escola Politécnica. A seguir, analisamos alguns dos temas a respeito dos quais Anhaia Mello foi convocado a se manifestar em nome da Escola Politécnica.

13 De acordo com Ficher (2005, p. 144), a partir do $7^{\circ}$ Regulamento da Escola Politécnica, de dezembro de 1925, essa cadeira incorporou os conteúdos urbanísticos anteriormente dados na cadeira de "Hidráulica Urbana e Saneamento das Cidades" do $2^{\circ}$ ano do curso de engenheiros civis e na parte prática de "Arquitetura das Cidades", ministrada apenas entre 1918 e 1925 aos estudantes do curso de engenheiros arquitetos.

14 Antes de tornar-se catedrático, Anhaia Mello substituiu Ramos de Azevedo na cadeira de Arquitetura Civil e Composição Geral entre maio de 1922 e fevereiro de 1923 e entre julho e novembro de 1926. Também substituiu Alcides M. Barbosa, catedrático de Geometria Descritiva, entre fevereiro e agosto de 1924. Ao mesmo tempo, Alexandre Albuquerque havia substituído Ramos de Azevedo na cadeira de Composição Geral.

15 Em 1947, Zenon Lotufo trabalhou como interino de Artigas, durante sua viagem de estudos aos Estados Unidos. 


\section{Comissão Julgadora em Concursos de projetos de arquitetura e urbanismo}

Na Pasta Funcional do docente constam ofícios comunicando que Anhaia Mello foi designado para integrar Comissões Julgadoras de concursos de Arquitetura na Cidade de São Paulo. Foi o caso da apresentação de diretrizes para um projeto definitivo de transposição do Vale do Anhangabaú, onde se encontrava o Viaduto do Chá, em 1934 (Ofício n 521 de 29/11/1934, Gabinete do Prefeito do São Paulo) e da avaliação dos anteprojetos para o Paço Municipal (1939). Nesse concurso, Artigas concorreu em parceria com Warchavchik, obtendo a segunda colocação.

O Ofício n 134 da Prefeitura Municipal de São Paulo, de 04 de maio de 1939, endereçado ao diretor da Escola Politécnica, informava que os nomes a comporem a Comissão Julgadora dos anteprojetos para o Paço Municipal haviam sido aqueles primeiros indicados por cada uma das instituições consultadas, de modo que a lista se constituía dos nomes a seguir: Luiz de Anhaia Mello (representante da Escola Politécnica), Heribaldo Siciliano (Instituto de Engenharia), Adhemar Queiroz de Moraes (Escola de Engenharia Mackenzie), Ary Torres (Sociedade Amigos da Cidade), João Ulhôa Cintra (Departamento de Obras), Francisco Silva Telles (Representante dos Concorrentes), Nestor de Figueiredo (Indicação do Prefeito), Dácio de Moraes (Indicação do Prefeito) e um membro ainda não indicado, representante da Escola Nacional de Belas Artes ${ }^{16}$. A informação da escolha do nome de Anhaia Mello foi transmitida pelo diretor Henrique Jorge Guedes por meio do Ofício $n^{\circ}$ D-39/232, de 05 de maio de 1939. Todavia, aparentemente o politécnico não se ocupou da avaliação dos projetos, posto que sua assinatura não consta no Parecer Oficial emitido pela referida Comissão, de 05 de julho de 1939, que foi assinado por João Ulhoa Cintra, Dácio de Moraes, Francisco Silva Telles, Heribaldo Siciliano, Jorge Przirembel, Francisco Kosuta, Ary Torres, Ademar de Moraes e Carlos Gomes Cardim (LIRA, 2007, p. 14).

Participação na política urbanística da cidade

Em 1947, Anhaia Mello foi designado pela diretoria da Escola Politécnica para integrar a Comissão Orientadora do Plano da Cidade, da Prefeitura Municipal de São Paulo. Em 13 de setembro de 1952, foi indicado para avaliar os aspectos técnicos de um projeto de lei para o Código de Obras, a pedido de seu autor, o Presidente da Câmara Municipal. O projeto de lei deveria ser analisado pelo responsável pela Cadeira de Urbanismo e pela Cadeira de Noções de Arquitetura e Construções Civis; Higiene das Habitações.

\section{Participação em congressos e encontros de arquitetura e urbanismo}

Anhaia Mello também foi escolhido entre os professores da Escola Politécnica para representá-la por ocasião do $1^{\circ}$ Congresso Brasileiro de Arquitetos entre 26 e 30 de janeiro de 1945, conforme o Ofício n D-69/45. Em 1951, por ocasião do terceiro Seminário Regional de Assuntos Sociais da União Pan-Americana, o diretor da Escola Politécnica, Antonio Carlos Cardoso, solicitou a Anhaia Mello que cooperasse com o seminário, especialmente sobre o ponto "Habitação popular e Urbanismo", um dos quais seriam discutidos no evento (Cf. Ofício $n^{\circ}$ 238/51, de 14 de fevereiro de 1951). 


\section{Coordenação de projetos urbanísticos da Cidade Universitária da USP}

Através da Portaria n 106 de 27 de outubro de 1948, o Reitor da Universidade de São Paulo, Lineu Prestes, nomeou Anhaia Mello presidente da Comissão da Cidade Universitária, junto com Ernesto de Souza Campos, Christiano Stockler das Neves, Adriano Marchini e José Maria da Silva Neves, responsáveis por viabilizar a criação do Campus da Universidade de São Paulo. O urbanista esteve à frente desta comissão até 1951, quando solicitou sua dispensa das funções de membro e presidente da comissão (Ofício n ${ }^{\circ}$ A-313, de 04 de abril de 1951). O debate sobre a construção da Cidade Universitária iniciara-se anteriormente. Entre 1944 e 1945, Anhaia Mello ficou responsável por recolher questionários encaminhados aos professores catedráticos da Escola Politécnica quanto às novas instalações na Cidade Universitária, conforme documentação existente na Pasta Funcional do docente. O assunto também foi tratado nas reuniões da Congregação da Escola. Na 629a Reunião da Congregação, em 28/04/1945, os professores votaram favoravelmente à transferência das instalações da Escola Politécnica para a Cidade Universitária no Butantã (XIV Livro de Atas da Congregação, p. 17-18).

A participação da Escola Politécnica no processo de criação da Cidade Universitária também havia sido defendida por Artigas ainda em 1946, durante sua viagem aos Estados Unidos, quando o arquiteto reivindicou que esta deveria ter um corpo técnico qualificado, a ser ouvido com relação aos interesses da universidade.

O reitor para construir a cidade [universitária da USP], veio para os EUA acompanhado de um filho menor de idade e um engenheiro eletricista, ao mesmo tempo em que mandava um fotógrafo de uma escola de dentistas para ver o que se poderia copiar do Chile. E a nossa escola de arquitetura na Politécnica não foi consultada muito justamente porque não tinha autoridade para nada. Absolutamente nada (Carta de Artigas a Oswaldo Corrêa Gonçalves, 1946).

\section{Parecer sobre cursos livres e palestras de arquitetos e urbanistas estrangeiros}

Anhaia Mello também dava pareceres relativos a cursos ministrados por arquitetos visitantes na Escola Politécnica, como foi o caso do italiano Roberto Vighi e do americano Kenneth J. Conant, em 1947. O primeiro desejava ministrar um curso de extensão em História da Arquitetura. Embora não tenha sido possível acessar o programa proposto, Anhaia Mello considerou que metade do curso não despertava interesse, por remeter ao "problema arqueológico em arquitetura”, tema que considerava ultrapassado. Nas suas palavras, "seria

16 Os nomes escolhidos, embora representassem instituições distintas, revelam a importância da Escola Politécnica para a formação dos quadros que institucionalizaram a profissão de engenharia e de arquitetura e urbanismo em São Paulo. Heribaldo Siciliano formou-se engenheiro arquiteto naquela escola em 1903; Ary Torres, além de docente da politécnica, foi também um dos fundadores do IPT; João Ulhôa Cintra, engenheiro civil formado na Poli em 1911, também foi professor substituto na instituição; Francisco Silva Telles formou-se na Politécnica em 1908. 
muito mais interessante que o Prof. Vighi propusesse um programa mais atual, encarando principalmente o problema urbanístico, que é hoje fundamental e dando a conhecer a obra dos urbanistas da nova escola italiana, que é das mais notáveis" (Ofício n D-595/1947, Processo D-016/47). O catedrático demonstrou mais interesse na vinda do norte-americano Kenneth John Conant para professar conferências sobre arquitetura americana. Curiosamente, Conant, também era arqueólogo e historiador especializado em arquitetura medieval ${ }^{17}$.

\section{Regulamentação da profissão, relação com Conselho Profissional e demais instituições}

Em diversas ocasiões, Anhaia Mello foi delegado do CREA representando as escolas de engenharia ou foi convidado a manifestar seu parecer sobre questões discutidas no âmbito daquele Conselho. Dentre elas, destacamos o debate acerca da regulamentação profissional.

Entre 1958 e 1959, a Congregação da Escola Politécnica foi chamada a se manifestar sobre a regulamentação das profissões regidas pelo Conselho Federal de Engenharia e Arquitetura. Solicitava, em particular, atenção à situação dos arquitetos e dos urbanistas face à nova legislação (Ofício Circular Confea $n^{\circ} 29$, de 4/09/1959). Houve um embate entre o Confea/CREA e o IAB (Ofício Circular Confea n ${ }^{\circ} 8$ de 1/04/1959). O Confea vinha estudando a regulamentação profissional desde março de 1958 e no decorrer do processo foi apresentada uma proposta do IAB, que criava um órgão específico para os profissionais de arquitetura, em substituição ao Confea e aos CREAs. Os argumentos do Confea contra o projeto do IAB eram, dentre outros, que essa proposta restringia as atribuições do arquiteto, vedando-lhe o direito de construir, e suprimia da carreira e das atribuições o titulo de urbanista. Contudo, no projeto de lei apresentado pelo IAB, tratava-se justamente do contrário, indicando que a direção de obras, bem como as atividades de planejamento urbano e regional, dentre outras, deveriam ser de competência exclusiva de arquitetos. Este embate inscreve-se na luta pela autonomia profissional dos arquitetos. Se a primeira regulamentação profissional federal, de 1933, avançava no sentido de exigir nível superior para a realização de atividades ligadas à construção, muitas das competências foram ali estabelecidas de forma comum aos arquitetos e aos engenheiros civis (SILVA, 2010, p. 83). A proposta do IAB em 1958 avançava, definindo as atribuições que deveriam ser exclusivas de arquitetos, retirando-as do quadro de competências dos engenheiros. Nesse sentido, podemos também inserir a própria fundação da FAUUSP em um contexto mais amplo de institucionalização do campo, por meio da independência da arquitetura face à engenharia. Na proposta do IAB, uma das estratégias para alcançar esse objetivo consistia em identificar a atividade do projeto como atribuição exclusiva do arquiteto, à semelhança do que vinha sendo proposto por Stockler das Neves desde os anos 1920. Percebe-se que havia dois objetos de disputa distintos e independentes no campo de arquitetura no momento da constituição da FAUUSP: um era a autonomia em relação à engenharia, para o qual arquitetos de diferentes vertentes e linguagens uniram suas forças; o outro era a consolidação da arquitetura moderna como 
vertente hegemônica em São Paulo, com suas consequências sobre a luta pela industrialização da construção e racionalização do projeto, para o qual esse uníssono não tinha lugar.

Solicitado a manifestar-se quanto a este processo, Anhaia Mello, respondeu através do Centro de Pesquisas e Estudos Urbanísticos da FAUUSP. O especialista foi contrário à proposta do IAB, considerando que tais atividades não deveriam ser de competência exclusiva de arquitetos, discutindo em especial o caso do planejamento urbano. Para justificar seu entendimento, Anhaia recorreu às resoluções acordadas em encontros internacionais realizados naquele ano, como o Seminário de Técnicos e Funcionários de Planejamento Urbano organizado pelo Centro Interamericano de Vivenda e Planejamento, em Bogotá, e o Congresso Internacional de Arquitetura realizado pela UIA em Moscou. Nos documentos assinados nesses eventos, defendia-se, respectivamente, que as equipes de profissionais atuantes em planificação urbana deveriam ser coordenadas por um especialista em urbanismo, não remetendo, portanto, à competência exclusiva do arquiteto; e a multidisciplinaridade das equipes que estudam problemas de urbanismo. Anhaia Mello concluiu afirmando que: "Esse conceito de exclusividade está hoje superado, porque o próprio urbanismo já superou a fase arquitetônica, dos arranjos urbanos, e percorre a estrada larga das considerações sociológicas e humanas na ordenação territorial" ${ }^{18}$ (Parecer de 11 de novembro de 1958).

Aparentemente, a Escola Politécnica não mantinha uma relação muito próxima com o IAB. Além da divergência de ideias observada no processo acima descrito, em 1947, o presidente do IAB, Eduardo Kneese de Mello, solicitou à Congregação da escola que fosse designado um engenheiro arquiteto para tomar parte em uma caravana para visitar exposições de arquitetura na Europa (Processo D-007/47 da Escola Politécnica). Nenhum dos professores teve disponibilidade para participar. No parecer de Anhaia Mello, encarregado pela direção da Escola Politécnica de dar seu parecer sobre o convite, questionou quem se encarregaria do custeio da viagem, avaliando que "seria muito interessante que um arquiteto entre os professores e assistentes da escola quizesse e pudesse ir", adiantando que ele próprio não poderia realizar a viagem, podendo-se consultar os demais professores da Escola (Ofício de 31 de março de 1947). Os demais professores consultados, Bruno Simões Magro, José Maria da Silva Neves e Felisberto Ranzini também declararam que não poderiam realizar a viagem. De modo que seu diretor, Henrique Jorge Guedes, respondeu em 14 de maio de 1947 que "consultados os Engenheiros Arquitetos desta Escola, não puderam aceitá-lo [o convite] em virtude do grande atrazo verificado no início do corrente ano letivo, o que os impede de se ausentarem de S. Paulo para evitar maior atrazo no desenvolvimento dos respectivos programas" (Ofício $n^{\circ}$ D-428/47). Essa falta de entrosamento sinaliza que a Escola Politécnica e o IAB representavam duas tendências distintas em relação ao campo profissional.

18 Esse é um ponto de conflito central entre as posições de Anhaia Mello e de Artigas e demais arquitetos ligados ao IAB. Trata-se de duas visões distintas do que seja o urbanismo, um abstrato, calcado em leis reguladoras, e outro associado à ideia de projeto da cidade. Essa divergência será retomada no capítulo 04 desta dissertação. 


\section{Colaboração com cursos externos à Escola Politécnica}

Em 1945, a Escola Politécnica foi convidada pelo Instituto de Higiene, que se encontrava em vistas de ser convertido na Faculdade de Higiene da Universidade de São Paulo, a colaborar com um "Curso de Saúde Pública”, especialização voltada para médicos. O programa estava baseado em um curso ministrado pelo Instituto Oswaldo Cruz, no Rio de Janeiro. Dessa forma, pedia-se aos professores ligados a especialidades afins com o conteúdo proposto para que se encarregassem de determinadas aulas. Os pontos a cargo da Escola Politécnica eram: 1) Higiene aplicada às construções. Saneamento. 2) Habitação. Preceitos de Higiene. Insolação. Iluminação Natural. Atmosfera das Habitações. Ventilação. Refrigeração. Unidade nas habitações. Regulamentação no Brasil. 3) Construções Hospitalares. 4) Construções escolares. Iluminação das classes. 5) Projeto das cidades sob o ponto de vista da higiene. Essas aulas seriam distribuídas entre os professores Anhaia Mello, Lucas Nogueira Garcez (o conteúdo relativo à Cadeira de Hidráulica, Hidráulica Urbana e Saneamento) e Antonio Carlos Cardoso (o conteúdo relativo à iluminação artificial).

\section{As posições urbanísticas de Anhaia Mello}

Os dois principais estudos tomados como referência nesta dissertação para a sistematização das posições urbanísticas de Anhaia Mello são a tese de Feldman e a dissertação de Arasawa. A partir de duas perspectivas distintas, ambos os autores trazem reflexões que muito contribuem para a compreensão do seu pensamento e de sua inserção social em São Paulo. Feldman (2005, p. 21) considerou Anhaia Mello o principal representante de uma das três vertentes de pensamento que influenciaram a atuação dos urbanistas paulistanos a partir dos anos 1940, ao lado daquela representada por Prestes Maia e a do padre dominicano Louis-Joseph Lebret. Estudando o processo de construção do zoneamento municipal em São Paulo entre 1947 e 1972, a autora reconheceu a importância da influência de Anhaia Mello sobre as ideias e práticas incorporadas pela administração a partir de 1947. Suas propostas remetiam ao urbanismo desenvolvido nos Estados Unidos a partir dos anos 1920, sobretudo a partir das matrizes ligadas à Scientific Management School e ao Regional Plan of New York and its Environs (1923-1929) realizado pela Russel Sage Foundation (FELDMAN, 2005, p. 27). Para a autora, portanto, sua relevância no processo de institucionalização do urbanismo em São Paulo deveu-se à influência de suas ideias na estruturação dos órgãos municipais de urbanismo e no processo de implementação do zoneamento através do trabalho desenvolvido nesses órgãos.

Arasawa, por sua vez, identificou como o urbanista construiu uma prática específica, que tinha como principal instrumento o discurso (e não o desenho), "deslocando o foco das justificativas técnicas para as determinações socioculturais das soluções técni- 
cas" (ARASAWA, 2002, p. 08). Anhaia Mello se contrapunha, dessa forma, ao setor de engenharia municipal de São Paulo, cujo principal feito teria sido a realização do esquema radial-perimetral, vinculado ao processo de ocupação e valorização de áreas periféricas e à descentralização populacional. Segundo o autor, a atuação dos engenheiros municipais estava ajustada aos interesses das classes dominantes e essas ações eram fundamentadas na literatura urbanística internacional, de forma a fundamentar aquelas intervenções urbanas. Todavia, no contexto de reconhecimento de legitimidade das ideias estrangeiras, Anhaia Mello se apresentou como um contraponto, reivindicando "o poder de organizar o espaço urbano e submeter à lógica do pensamento urbanístico, purgando de qualquer interesse individual ou de grupo, todos os demais poderes, ao agente com o maior capital de reconhecimento no campo do urbanismo" (ARASAWA, 2002, p. 06). Segundo o autor (1999, p. 10), há um impasse entre a centralidade atribuída a Anhaia Mello na história do pensamento urbanístico paulistano e a frustração dos objetivos irrealizados divulgados em suas conferências. Dessa forma, Arasawa inseriu o pensamento de Anhaia Mello em um contexto de disputas intelectuais realizadas em São Paulo entre os anos 1920 e 1930, relacionadas com as demandas responsáveis pela instituição do "Estado Novo" (idem, p. 11). Assim, o autor explicitou estratégias que Anhaia Mello adotou para legitimar sua "árvore do urbanismo", no âmbito de um discurso cuja principal finalidade era posicioná-lo em um determinado lugar de poder.

Esses trabalhos evidenciaram que a defesa das ideias urbanísticas e da institucionalização do urbanismo de Anhaia Mello ultrapassaram largamente o âmbito da Escola Politécnica ou da FAUUSP. Como vereador, em 1920, Anhaia Mello já começava a tratar dessa questão, apresentando um projeto de lei visando regulamentar o custeio do calçamento por parte dos empreendedores de loteamentos (FICHER, 2005, p. 145). Todavia, sua trajetória na direção do urbanismo tornou-se definitiva a partir de 1926, quando assumiu a cadeira de Composição Geral, Estética e Urbanismo na Escola Politécnica. Pouco tempo depois, entre 1928 e 1930, o engenheiro arquiteto expôs suas ideias fundamentais acerca da disciplina em três ciclos de conferências realizadas no Instituto de Engenharia, que manteria nos mais de quarenta anos de carreira subsequentes quase inalteradas.

Nesse conjunto de palestras, o urbanista tratou dos "Problemas de Urbanismo", versando sobre as "bases para a resolução do problema técnico"; do "recreio ativo e organizado nas cidades modernas" e do "problema econômico dos serviços de utilidade pública". Nas "bases para a resolução do problema técnico", Anhaia Mello apresentou os elementos constitutivos de sua proposta, sintetizados na imagem de uma "árvore do urbanismo". A raiz dessa árvore representava a "conquista da opinião pública", a ser alcançada através da propaganda a fim de "formar um ambiente social favorável" à realização do urbanismo ${ }^{19}$.

19 Nesse sentido, incluem-se as próprias conferências do urbanista. "Anhaia sugeria que se fizesse algo que ele mesmo já fazia, no e pelo movimento de sua argumentação e da autoridade que reivindicava. (...). Na 'árvore do urbanismo', as conferências possuíam um valor pragmático específico: eram sua modalidade particular de prática, já que se destinavam a atrair, formar e mobilizar elites, transformando capitalistas, técnicos, bacharéis em 'apóstolos' desse 'evangelho de regeneração social”' (ARASAWA, 1999, p. 37). 


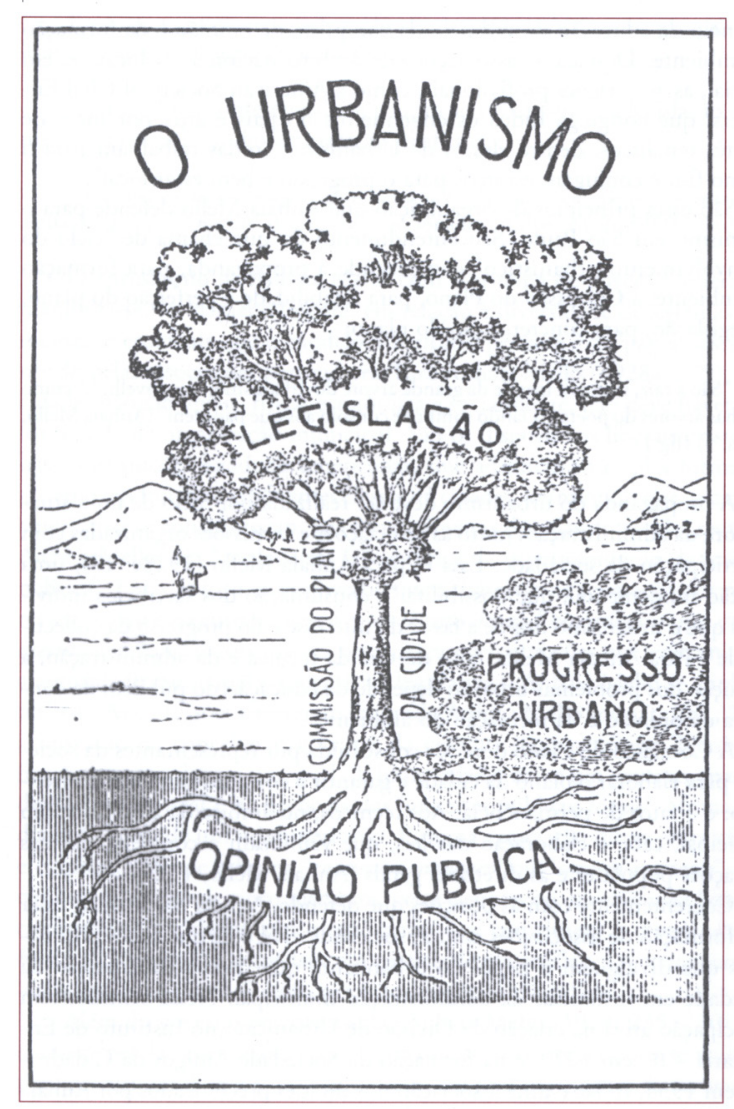

Figura 2 - Representação da "árvore do urbanismo" de Anhaia Mello

Seu tronco consistia na "Comissão do Plano", organização constituída por membros da sociedade civil, de caráter consultivo ou deliberativo, que deveria estar vinculada diretamente ao prefeito. Era o dispositivo que garantia a continuidade da orientação do plano, a despeito das mudanças administrativas - seu fator de permanência (FELDMAN, 2005, p. 59). Com a Comissão do Plano, Anhaia Mello propunha a criação de um órgão dedicado exclusivamente à elaboração e viabilização do plano, desvinculado e acima dos órgãos municipais encarregados de tarefas cotidianas ligadas à cidade. Por fim, a frondosa copa da árvore correspondia à legislação, responsável por instituir as determinações do plano. A sombra dessa árvore seria o progresso urbano.

Em "O recreio ativo e organizado nas cidades modernas", Anhaia Mello defendeu que um dos principais objetivos do urbanismo moderno era o de restabelecer o contato entre o homem e a natureza. Na visão do urbanista, a forma ideal de realizar essa reconexão era levar a cidade para o campo, com a implantação de cidades-jardins ou cidades regionais. Entretanto, como solução provisória para grandes metrópoles como São Paulo, o campo poderia ser trazido à cidade mediante a criação de um "sistema de recreio ativo e organizado" (TIMOTEO, 2007, p. 01). Esse sistema tinha por propósito restabelecer as energias dos trabalhadores, ampliando a participação da população na vida em sociedade, contribuindo com a convivência pacífica em grupo (idem, p. 02). Tal proposta apresentava-se como contraponto ao clima hostil que o urbanista reconhecia na vida na metrópole (ANHAIA MELLO, 1954, p. 36).

Finalmente, em suas palestras referentes à regulamentação dos serviços de utilidade pública, Anhaia Mello procurou detalhar a função das empresas públicas e privadas na concessão de tais serviços. O Estado deveria ter como prerrogativa controlar o lucro das empresas privadas e fiscalizar os seus serviços. Para tanto, devia ser criada uma Comissão 
de Serviços de Utilidade Pública, com base no modelo norte-americano. Esse tema, em particular, parece ter influenciado seus estudantes do curso de engenheiros arquitetos, dentre eles o próprio Artigas, para quem suas aulas consistiam em "discursos contra a Light" (ARTIGAS, 1982, s/n).

Anhaia Mello defendia o planejamento regional, tendo como pressuposto a contenção do crescimento. A cidade, em sua visão, devia ser finita, "completa, acabada, obra de arte" (CPEU, 1963a, p. 17), contra as metrópoles "congestionadas", de crescimento "ilimitado" ${ }^{\prime 20}$. O crescimento se daria no âmbito regional, através de uma rede de cidades pequenas ou médias. $\mathrm{O}$ autor afirmava que:

Não se mede pelo tamanho, nem pelo número de habitantes, nem pela cifra do orçamento municipal, o valor real de um núcleo urbano-rural para a vida feliz dos seres humanos. Mede-se pelo standard de vida, elevado, generalizado, seguro, dos seus habitantes; pelo índice de integração moral e social que o caracterize (CPEU, 1963a, p. 12).

O limite físico da cidade deveria ser demarcado por um cinturão verde, que tendo função de abastecimento, deteria o avanço da expansão da mancha urbana (ANHAIA MELLO, 1954, p. 17).

Os principais instrumentos de planejamento defendidos por Anhaia Mello foram também adotados nas demais vertentes de urbanismo que tiveram eco em São Paulo, como a de Prestes Maia ou mesmo do urbanismo funcionalista ligado ao Movimento Moderno em Arquitetura. Contudo, não se deve acreditar que a adoção da mesma terminologia remetesse aos mesmos conceitos ${ }^{21}$. Um dos mais importante deles era o zoneamento, que devia viabilizar a cidade funcional (macrozoneamento) e estabelecer e índices construtivos diferenciados por setores (microzoneamento ou zoneamento diferencial), interligados pelos meios de transporte e comunicação. Os usos urbanos deveriam estar próximos, mas não misturados: "é um problema de ordem; um lugar para cada coisa e cada coisa no seu lugar" (CPEU, 1963a, p. 18). Esse instrumento visava proteger o "bem comum" contra interesses privados. Como exemplo, o autor citava a necessidade de "proteger a residência isolada, térrea ou de sobrado, contra a intromissão indébita dos de residência coletiva ou apartamentos, que vão roubar o sol, o arejamento, a boa iluminação natural, o sossego, a privatividade das residências isoladas" (idem, p. 19). Com o zoneamento também se pretendia interferir sobre a localização das indústrias. Tratava-se de um zoneamento compreensivo, que abrangia a totalidade do município, com função protetora e reguladora (LIRA, 2005, p. 10). Feldman observou que, na prática, esse instrumento teve o papel de proteger os interesses dos proprietários contra a convivência com usos que induzissem a desvalorização imobiliária.

20 Topalov (1990, p. 89) observou que o "congestionamento" das cidades é uma problemática que se encontra na origem do planejamento urbano, que o autor situou como sendo por volta de 1910. Segundo ele, as várias disciplinas que se ocuparam dessa temática, em suas diferentes vertentes, enfrentaram a questão do congestionamento das cidades.

21 Parte dessas diferenças conceituais, especialmente as referentes ao Movimento Moderno em arquitetura e ao pensamento de Anhaia Mello serão exploradas no Capítulo 04 desta dissertação. 
Outro instrumento defendido por Anhaia Mello era a Unidade de Vizinhança, que, para o urbanista, consistia na "base estrutural das cidades", prestando-se a promover sua "saúde social”. Ela garantia o espírito comunitário e a vida familiar, por uma disposição mais conveniente à atividade da vida cotidiana (CPEU, 1963a, p. 34). Visando diminuir a possibilidade de acidentes envolvendo automóveis, o número de cruzamentos devia ser reduzido, através da organização dessas unidades de vizinhança em superquadras. Cada superquadra, com 1000 pessoas, consistia numa "unidade residencial", dotada de determinados equipamentos sociais. A unidade de vizinhança constituir-se-ia num agrupamento de dez superquadras (10.000 pessoas), que deveria possuir outros equipamentos coletivos, além de um centro comercial. A cidade, reunião de entre 5 e 15 unidades de vizinhança, teria além desses diversos centros e equipamentos, o centro principal, "cívico, administrativo, cultural e de negócios". O controle da densidade demográfica se justificava pelo adequado dimensionamento da população residencial a ser atendida pelos serviços de utilidade pública, pelas vias de comunicação e pelos transportes coletivos.

Por fim, Anhaia Mello defendia a polinucleação, com a hierarquização de centros no espaço urbano, desde o centro principal aos secundários, relativos às unidades de vizinhança, unidades residenciais até o centro dos "lares individuais - a sala comum ou "living"” (CPEU, 1963a, p. 29). Trata-se do que ele chamava de "cidade em cacho" em vez de "cidade em alvo" (idem, p. 34). Nas publicações do CPEU, afirmava-se esses eram princípios "universalmente aceitos segundo os quais as cidades devem ser planejadas como organismos polinucleados, com diversos centros e sub-centros urbanos, visando uma maior racionalidade na distribuição dos equipamentos sociais nos bairros" (CPEU, 1964a, p. 21).

Repetidamente o autor ressaltou o caráter cívico da cidade e o papel do planejamento de corrigir os problemas que ele identificava com a perda de interesse pelo coletivo, enfatizando o objetivo "humano e social" do planejamento. As noções de "felicidade geral", "bem comum", reiteradamente levantadas para justificar os objetivos do planejamento, consistiam em argumentos irrefutáveis e indiscutíveis, porém de significado difuso e de difícil explicação. Ainda assim, esse interesse, era limitado pelo caráter "politicamente neutro" atribuído ao processo de planejamento: “planejamento, como qualquer técnica, é politicamente neutro; há um processo, pois, que deve ser seguido por todos, para acertar" (ANHAIA MELLO, 1945, apud FELDMAN, 2005, p.49). Acreditamos que a adoção de tal imagem de coletividade, vaga e difusa, servisse como artifício de "conquista da opinião pública", um dos elementos basilares da "árvore do urbanismo" de Anhaia Mello. A definição de "bem comum", tal como apresentada por Anhaia Mello, sinaliza os seus próprios limites, uma vez que se tratando do "maior bem para o maior número, eis que seria difícil - se não impossível - realizar o bem total de todos" (CPEU, 1963, p. 13), perspectivas de transformações mais estruturais da sociedade não foram sequer colocadas em pauta. Esses limites foram explicitados em seus próprios textos, por exemplo quando defendeu que o planner devia visar "the man in the street and the woman in the window" (ANHAIA MELLO, 1954, p. 25).

Outro aspecto fundamental do processo de planejamento, segundo Anhaia Mello, era seu caráter multidisciplinar. O urbanista enfatizava a importância de se contar com a colaboração de especialistas de modalidades tão distintas quanto a sociologia, a geologia, a geografia, etc. Essa equipe de especialistas devia ser coordenada pelo urbanista, profissional especializado, formado em uma pós-graduação em urbanismo. 
A partir das conferências do final da década de 1920, o urbanista consolidou-se como uma autoridade sobre o assunto, publicando nos meios especializados inúmeros artigos e sendo convocado pela Congregação da Escola Politécnica a representá-la nos assuntos de urbanismo. Durante os breves períodos em que foi prefeito da cidade, tentou aplicar algumas de suas teses. Dentre elas, destacamos a iniciativa de instituir a Comissão Municipal de Serviços de Utilidade Pública (Ato $n^{\circ} 32 / 1930$ ), em conformidade com o que defendera como meio de fiscalizar os serviços de utilidade pública em suas conferências. Além disso, na tentativa de separar o setor responsável pelo planejamento daquele ligado às atividades de rotina relativas à cidade, Anhaia Mello, por meio do Ato n 50/1931, desdobrou a Seção de Urbanismo da Diretoria de Viação e Obras Públicas em duas. Uma "Seção de Urbanismo" ficou encarregada do estudo do sistema viário, da canalização de rios e das questões de urbanização e a outra, de "Cadastro da Cidade", ficou responsável por organizar plantas, realizar serviços de topografia, fixar alinhamentos e nivelamentos, e cuidar da nomenclatura de vias e da numeração de imóveis (FELDMAN, 2005, p. 46; FICHER, 2005, p. 145). Por meio do Ato $n^{\circ} 127 / 1931$, o prefeito também instituiu o zoneamento funcional para determinadas áreas da cidade. De acordo com Feldman (2005, p. 149), essa foi a primeira vez em que o termo "zoning" foi empregado na legislação urbanística de São Paulo. Essa lei demarcava "zonas funcionais" em que se restringia o uso e ocupação do solo a "habitações particulares-residenciais" e criava uma Comissão que não chegou a ser instituída, presidida pelo prefeito e constituída por técnicos da Diretoria de Obras e Viação para elaborar um "regulamento differencial de especialização (zoning) para toda a cidade" (idem, p. 150).

As posições de Anhaia Mello contrastavam com a prática do urbanismo em São Paulo, a partir da engenharia municipal, vertente que teve como grande representante o engenheiro Prestes Maia e seu Plano de Avenidas. Apesar de ter conseguido se afirmar como "autoridade" em matéria urbanística em São Paulo, na prática sua proposta não ecoava no seio da Escola Politécnica.

A prática dos engenheiros municipais também tinha motivações históricas ligadas ao fortalecimento da identidade profissional. As intervenções urbanísticas realizadas no âmbito da engenharia nos primeiros anos do século XX, e que trouxeram bastante prestígio ao campo profissional, eram sobretudo ligadas à construção de obras de infraestrutura (notadamente as ferrovias), de expansão das redes de serviços urbanos e de embelezamento, modernizando as cidades brasileiras que desde o fim do século XIX, com a introdução do trabalho livre, vinham concentrando cada vez mais população.

Os setores das elites que compunham a categoria dos engenheiros tomariam para si a tarefa de criar uma imagem de modernidade no Brasil (...) a engenharia deveria mostrar ao mundo, através de suas realizações, o "estado de nosso adiantamento" (...) (ARASAWA, 1999, p. 114).

Na construção da autoimagem dos profissionais de engenharia, somaram-se a valorização dos quadros técnicos, decorrente das transformações tecnológicas vividas a partir do fim do século XIX, e as teorias cientificistas, lideradas por Auguste Comte. Segundo Arasawa, para os seguidores desse politécnico francês, a valorização da engenharia como agente de progresso se contrapunha à elite política monárquica de bacharéis. Tal visão repercutiu na construção da identidade dos engenheiros, que passaram a se ver como um 
grupo social com vocação para elite dirigente (idem, ibidem). Em São Paulo, a fundação da Escola Politécnica em 1894 e do curso de engenharia do Mackenzie College em 1896 foram decisivas para a formação dessa elite.

(...) o surgimento do ensino de engenharia abriria a possibilidade não apenas para o surgimento de áreas de atuação e de saber específicas sobre a cidade, mas também uma série de disputas que buscam, a um só golpe, impor todo um leque de práticas legítimas de intervenção no espaço; excluir ou rebaixar outras; e fazer conhecer e reconhecer um conjunto de novos símbolos de distinção (títulos acadêmicos, diplomas, registros profissionais, etc.) (ARASAWA, 1999, p. 117).

Durante as três primeiras décadas do século $\mathrm{XX}$, o setor de obras municipais, que foi praticamente monopolizado por docentes da Escola Politécnica ${ }^{22}$, foi o âmbito mais poderoso para tratar das questões relativas aos problemas urbanísticos (idem, p. 135). Os engenheiros do setor de obras haviam elegido a resolução técnica dos problemas de tráfego e de saneamento do centro da cidade como eixo central de trabalho, mantendo-se uma continuidade entre eles (idem, ibidem).

Vemos que Anhaia Mello era uma voz dissonante dentro da Escola Politécnica, que alimentava o setor de obras municipal. Diante do processo de fortalecimento da engenharia a partir da valorização do saber técnico, não deve ter sido a toa que o urbanista referiu-se às "bases para a resolução do problema técnico" em suas conferências de 1928, ainda que viesse apresentar uma proposta bastante distinta da prática desenvolvida pela engenharia municipal.

Partindo de uma situação de relativa despreocupação com as necessidades materiais, dono de um alto capital de reconhecimento - fruto tanto da posição que Anhaia pai ocupava no corpo docente da Politécnica, quanto das fortes relações dos Anhaia Mello com Francisco de Paula Ramos de Azevedo (capital de sociabilidade); e acumulando ainda mais trunfos durante seu período escolar, coroado de notável êxito acadêmico, Anhaia pode dar-se ao luxo de, ocupando a maioria das posições dominantes no interior das instâncias de consagração na esfera técnica, na passagem dos anos 20 e início dos 30, construir para si uma posição nova na esfera técnica, produto da acumulação de capitais simbólicos de todas as instâncias de consagração: o Urbanismo (ARASAWA, 1999, p. 146).

22 Dentre eles, Victor da Silva Freire, formado nas escolas Politécnica de Lisboa e de Ponts et Chaussés de Paris, convidado pelo conselheiro Antonio Prado, primeiro prefeito de São Paulo, a chefiar a recém fundada Diretoria de Obras Municipais, João Florence Ulhôa Cintra, Arthur Saboya e Prestes Maia. Todos pertenciam aos quadros da Escola Politécnica. 


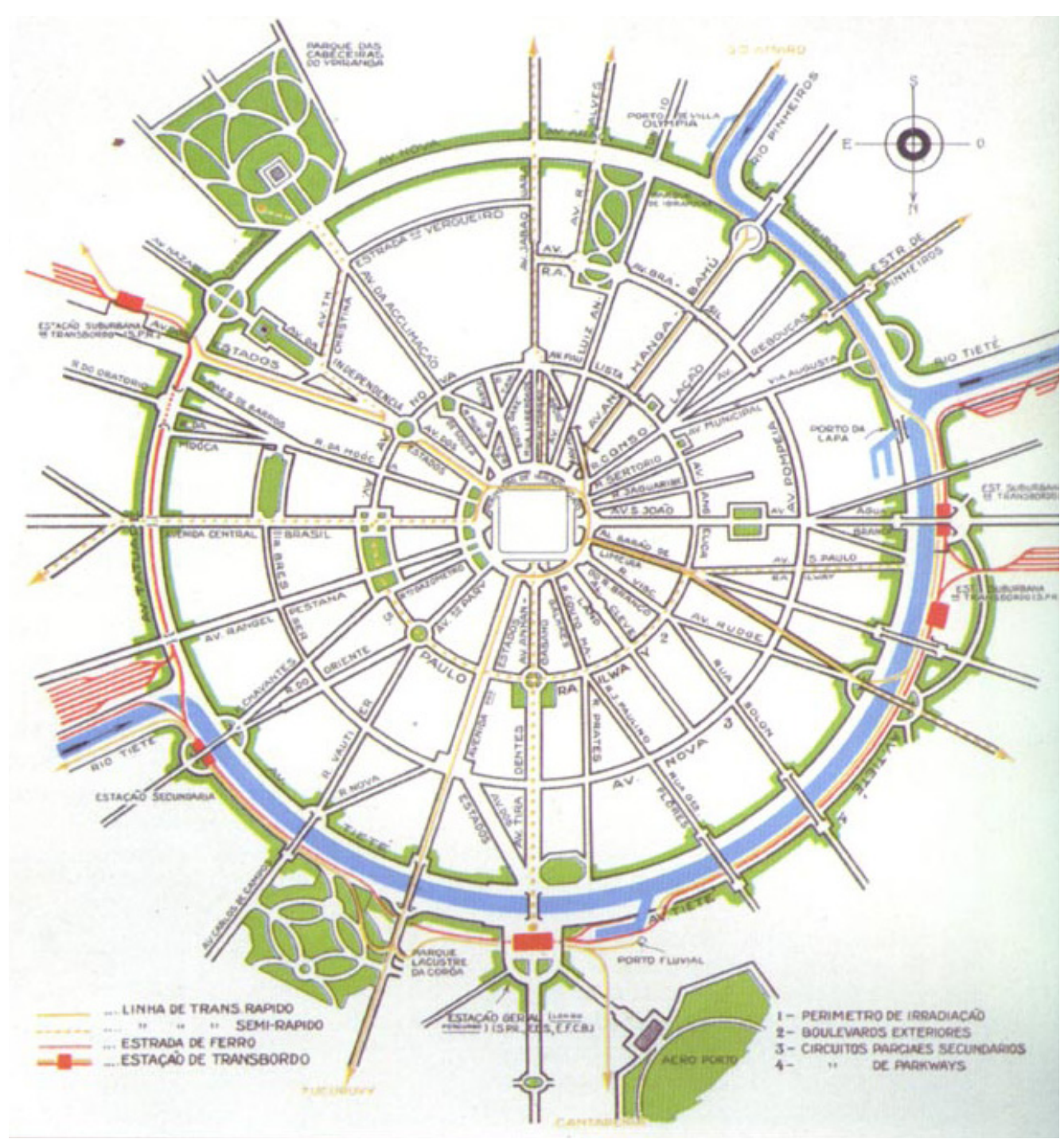

Figura 3 - O Plano de Avenidas, 1930, de Francisco Prestes Maia e João Florence de Ulhôa Cintra é representativo do urbanismo realizado pelos engenheiros politécnicos, especialmente no setor de obras da Prefeitura Municipal, ao qual Anhaia Mello se contrapunha.

Suas conferências no fim da década de 1920 renderam-lhe bons frutos nesse sentido. Foi, logo em seguida, eleito para a presidência do Instituto de Engenharia, despertou interesse na esfera dos técnicos, ampliando-lhe o reconhecimento.

Como apontou Arasawa, Anhaia Mello lançou mão de estratégias para estabelecer a ciência do urbanismo, visando "mudar a correlação de forças que determinara, até então, os rumos da evolução urbana da cidade" (1999, p. 146), que se encontrava, até então, nas mãos do setor de obras municipais ${ }^{23}$. Tal situação era bastante desfavorável para o catedrá-

23 Arasawa faz a interessante observação de que Anhaia Mello, ao longo de sua trajetória, ocupou diversos espaços institucionais ligados à esfera técnica, como no Instituto de Engenharia, na própria Escola Politécnica e no Liceu de Artes e Ofícios, sem jamais inserir-se no setor de obras municipal, que detinha os maiores poderes sobre as decisões urbanísticas. 
tico de urbanismo da Escola Politécnica. Parte significativa dessa estratégia consistiu em proferir um determinado discurso, sua árvore do urbanismo, apresentado como "verdade" no lugar certo, o Instituto de Engenharia, e na ocasião adequada. Isso revelou a importância da formação de uma opinião pública educada, sem a qual não poderia, chocando-se com o setor de obras municipal, instituir um lugar de poder superior ao executivo e legislativo, munido das razões da ciência (idem, p. 147). É nesse contexto que se deu o embate com Prestes Maia, que representava a visão da engenharia municipal e que, além de tudo, tornou-se prefeito de São Paulo em 1938.

A inserção de Anhaia Mello no campo da engenharia paulista a partir de meados dos anos 1920 e o modo como ele procurou instituir sua visão de urbanismo nesse contexto indicam a importância de se construir uma interpretação do papel da atuação desse urbanista para além da contraposição entre "expansão" e "contenção do crescimento" ou "interesses egoísticos" e "interesses coletivos", por exemplo. Em 1952, em um discurso em comemoração ao "Dia do Urbanismo", Anhaia Mello afirmava que falaria sobre o tema:

(...) em continuação a uma campanha que data mais de 20 anos, com escassos resultados, é certo.

O que se deve necessariamente atribuir aos deméritos do conferencista e jamais ao valor das teses enunciadas e defendidas, tôdas elas da mais alta transcendência para a redenção material e espiritual de incontáveis milhões de seres humanos (ANHAIA MELLO, 1952, p. 1-2).

Deixando a modéstia de lado, sua afirmação tanto era representativa de um trabalho "messiânico", solitário e ingrato, que o urbanista realizava para difundir o urbanismo voltado para a consecução do "bem comum" ${ }^{24}$, quanto refletia uma característica inerente ao urbanismo que defendia. Sem ainda saber, pouco tempo depois seria inaugurada uma era de elaboração de planos não realizados.

24 Ainda citando Arasawa: "Constituindo uma posição contra todas as outras, destinada a submetê-las a sua lógica, não dispondo nem de alianças com capitalistas, nem com os chefes de repartições técnicas, nem mesmo com os políticos portadores do projeto hegemônico da primeira república ou do Estado pós-30, restava a Anhaia Mello apenas a tentativa de converter seu reconhecimento específico, ganho inter pares, em reconhecimento social, alimentando-se aqui e ali dos pontos consensuais que se afirmassem no debate intelectual do momento, e da legitimidade conferida por uma imagem de abnegação" (ARASAWA, 1999, p. 149). 


\section{Anhaia Mello e a fundação da FAUUSP}

O imenso interesse de Anhaia Mello na fundação da FAUUSP, assim como a aliança com os arquitetos modernos para realizar esse empreendimento podem ser melhor compreendidos à luz da inserção do urbanista no meio técnico paulista a partir dos anos 1920, conforme acabamos de descrever. Após o primeiro marco regulador da profissão de engenheiros e arquitetos, em 1933, os arquitetos passaram a lutar por uma valorização de sua própria profissão face à engenharia, que viam obter mais vantagens do que sua própria. Portanto, fica desde logo claro que tanto Anhaia Mello quanto os arquitetos interessados na fundação da FAUUSP, dentre os quais seu assistente Artigas, desejavam ganhar autonomia e valorizar-se face à engenharia com vistas a constituírem as disciplinas de arquitetura e urbanismo sob novas prerrogativas. A arquitetura, sob os princípios racionais da construção e do funcionalismo, e o urbanismo, sob a base mais abstrata dos princípios do planejamento urbano do que a dos projetos urbanísticos de engenharia. Uma aliança poderia ser de grande utilidade para alcançar esse objetivo em comum.

Assim como na "esfera técnica" da engenharia Anhaia Mello soube conquistar espaços institucionais em que procurou fazer valer suas posições divergentes, na época de fundação da FAUUSP Anhaia Mello também se aproximou das instituições de arquitetura. Seus assistentes na cadeira da Escola Politécnica a partir de 1940, especialmente Artigas, mas também Zenon Lotufo, revelam o vivo interesse do urbanista em aproximar-se de arquitetos modernos. Anhaia Mello acompanhou de perto o fortalecimento da arquitetura moderna em São Paulo, especialmente através do IAB-SP. Em 1943, quando ocupava o cargo de Secretário de coordenou a sessão de fundação do departamento paulista enquanto representante do interventor federal. Representou a Escola Politécnica no I CBA, realizado em 1945. Nos primeiros anos de funcionamento da FAUUSP, chegou a compor a diretoria do IAB-SP, nas gestões de 1947-1948 e $1949^{25}$.

A aproximação de Anhaia Mello com o IAB-SP no período em que se fundava a FAUUSP é indicativa da aliança construída entre o urbanista e os arquitetos. A despeito de diferenças em relação à posição do IAB no que se refere às atribuições profissionais, Anhaia Mello não apenas participou de sua diretoria e de outras atividades daquele órgão, mas recebeu manifestações de apoio em outros momentos. Em 1951, quando Anhaia Mello se demitiu de seus cargos dirigentes na USP, o IAB solidarizou-se publicamente com o docente (DOSP, 22/06/1951, p. 38). Em 1961, apresentou um episódio do programa "Arquiteto na TV", organizado pelo IAB e transmitido pela TV Excelsior, sobre "Arquitetura e Planejamento" (DEDECCA, 2012, p. 69).

25 Participaram dessas administrações arquitetos como Eduardo Kneese de Mello, Abelardo de Souza, Hélio Duarte, Plínio Croce, Oswaldo Corrêa Gonçalves, Francisco Kosuta e Carlos Alberto Gomes Cardim Filho, na primeira gestão, e Eduardo Kneese de Mello, Abelardo de Souza, Lauro de Souza, Carlos Cascaldi, Wilson M. Fina, Francisco Kosuta, Carlos Alberto Gomes Cardim Filho na segunda. Quase todos vieram a lecionar na FAUUSP nos anos que se seguiram. 


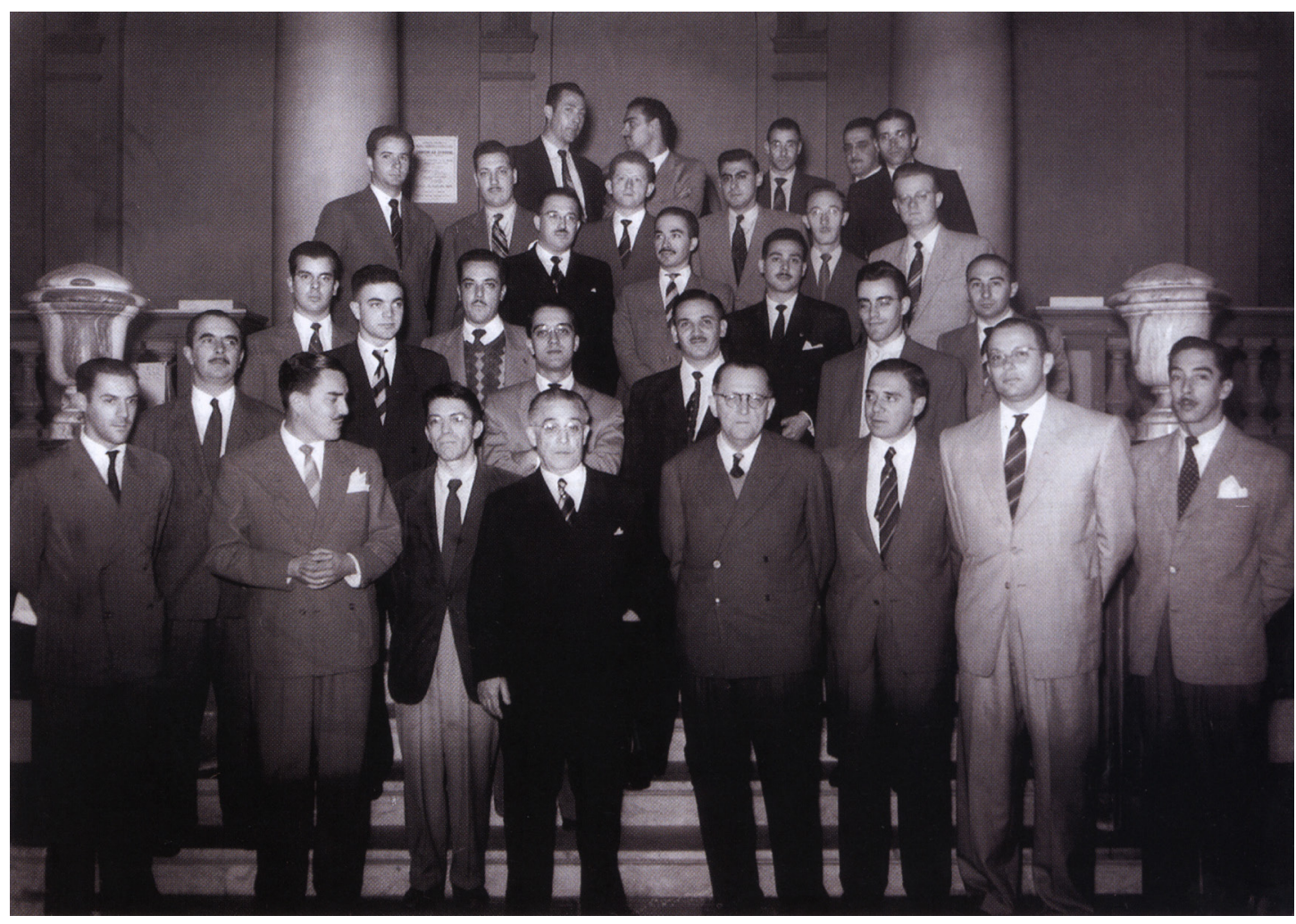

Figura 4 - Homenagem a Anhaia Mello pela criação da FAUUSP, agosto de 1948. Anhaia Mello, de terno preto, à frente, no centro da foto, tem Artigas ao seu lado esquerdo, um pouco atrás.

A ideia de uma aliança entre Anhaia Mello e Artigas como estratégia para alcançar um objetivo em comum de dois campos distintos - o urbanismo e a arquitetura - também se reflete na proposta de estruturação de dois cursos separados na nova faculdade, o que é tido como uma iniciativa do urbanista. Na concepção de sua fundação, ela deveria contemplar os conteúdos de arquitetura, na graduação, e urbanismo, na pós-graduação. Embora a criação de uma pós-graduação em urbanismo não tenha se efetivado no período em que esteve na FAUUSP, veremos adiante que Anhaia Mello notabilizou-se como o especialista em matéria de urbanismo da USP. Até sua aposentadoria, podemos afirmar que foi praticamente a única autoridade reconhecida neste assunto na instituição. Nestor Goulart Reis Filho, que estudou na FAUUSP entre 1951 e 1955, ingressando como docente em 1956, assinalou o caráter centralizador do catedrático politécnico. Segundo o arquiteto:

[Anhaia Mello] era um coronel, neto de barões, então ele achava que ali no terreiro só ele decidia. (...) Ele não deixou capim pra crescer em volta dele e nunca mais houve um catedrático de arquitetura em São Paulo (...) porque ele era o único galo no terreiro (apud SODRÉ, 2009, p. 108).

Não é surpreendente que Anhaia Mello tenha sido o engenheiro arquiteto catedrático designado para a coordenar a criação do curso de Arquitetura e Urbanismo da USP. Nos anos 1940, uma Comissão Especial foi encarregada de estudar o Ensino de Engenharia na Escola Politécnica, no contexto da realização de uma reforma do ensino superior, por ordem da Secretaria de Educação (Ofício nº D-577/43, de 15 de julho de 1943). No estudo apresentado pela Secretaria de Educação e Saúde Pública, a formação de engenheiros ar- 
quitetos não constava mais entre os cursos de engenharia, prevendo-se a criação do curso de arquitetura. O curso proposto contava com um biênio fundamental idêntico ao previsto para os de engenharia e um triênio de aplicação. No documento, também constava a criação de um curso de pós-graduação de urbanismo.

A criação da FAUUSP não consistiu, portanto, em um movimento isolado, de modo que não basta explicar a sua separação da escola de engenharia exclusivamente por iniciativa e motivações de seu corpo docente ou de interesses relativos a um determinado grupo de profissionais. A proposta estava inserida no contexto mais amplo de autonomização da arquitetura face à engenharia e às Belas Artes e era baseada no modelo federal que vinha sendo instaurado no Rio de Janeiro. Entretanto, interessa observar como os profissionais que tiveram a responsabilidade de realizar essa proposta em São Paulo, ligados à tradição politécnica paulistana, se posicionaram.

Anhaia Mello foi o encarregado de coordenar a reestruturação do curso de arquitetura da Universidade de São Paulo, a partir de 1946. No Ofício nº D-109/1946, de 30 de janeiro de 1946, encaminhado pelo diretor Paulo de Menezes Mendes da Rocha ao professor, transcreveu-se um telegrama encaminhado ao Interventor Federal pelos membros do Conselho de Orientação Artística de São Paulo, Carlos A. Gomes Cardim Filho, José Marques Campão, Mozart Tavares de Lima, Armando Belardi, José Maria da Silva Neves e Theodoro Braga, em que estes vinham solicitar a remodelação do Curso de Arquitetura da Escola Politécnica de São Paulo como Faculdade Superior de Arquitetura, nos moldes do padrão federal.

Na $641^{a}$ sessão da Congregação da Escola Politécnica, em 24/10/1946, discutiu-se o Processo n 9163/46 da Reitoria, relativo à proposta de doação do edifício à rua Maranhão pelos irmãos Sílvio e Armando Álvares Penteado, a ser destinado para a instalação de uma Faculdade de Arquitetura e Urbanismo. Anhaia Mello foi o responsável pela análise do processo. Em seu parecer, o docente considerava que a doação vinha em momento oportuno, remetendo à criação da Faculdade Nacional de Arquitetura pelo Governo Federal em 31 de agosto de 1945, tendo a Universidade de São Paulo "o dever de cuidar da instalação de idêntico instituto". Ainda segundo o parecer de Anhaia Mello, o curso ministrado no âmbito da escola de engenharia já não atendia às necessidades emergentes no campo da arquitetura e do urbanismo. Em suas palavras:

(...) a evolução social neste último século foi das mais notáveis da história humana e a Arquitetura, que é a arte representativa de uma época, tem que se desdobrar para bem servir às necessidades da civilização. O trabalho do Arquiteto hoje não se resume apenas à composição formal de 50 anos atraz, mas abrange toda a "ciência de planejar". (...) Ensino à altura dessas responsabilidades só poderá ser ministrado em uma Faculdade de Arquitetura organizada, nos moldes da Faculdade Nacional recém-criada" (XIV Livro de Atas da Congregação da Escola Politécnica, p. 6o).

É interessante notar, na manifestação do docente, a sua visão acerca das transformações sofridas pela arquitetura ao longo do século XX passava pela crítica do método da composição. Entretanto, na visão de Anhaia Mello, a superação do método de composição se encontrava no âmbito do planejamento. O grupo de arquitetos que lecionaria nas cadei- 
ras de Composição nos anos 1950 na FAUUSP faria uma crítica distinta à composição de arquitetura, voltando-se para os aspectos da função social da arquitetura, da funcionalidade do edifício, dentre outros. Anhaia Mello, em seu discurso à Congregação, justificava o alinhamento da arquitetura e do urbanismo em uma única instituição distinta da de engenharia, mediados pela "ciência de planejar". Do mesmo modo, os arquitetos, no âmbito da função social da arquitetura, propunham, através do plano, realizar a interface entre as duas disciplinas, como veremos no capítulo 04.

Na redação final da proposta referente à aceitação da doação do imóvel dos irmãos Penteado, reiterou-se que a Faculdade de Arquitetura da Universidade de São Paulo, em que se transformaria o curso de engenheiros arquitetos da Escola Politécnica, seria criada nos moldes do Decreto Lei $n^{\circ}$ 7.918/1945, referente à criação da FNA no Rio de Janeiro, e que deveriam ser tomadas, inclusive, as providências para dar início ao Curso de Urbanismo, conforme enunciado no referido Decreto Federal.

Sendo um dos principais articuladores da criação da FAUUSP, pode-se inferir que além do modelo proveniente do Rio de Janeiro, Anhaia Mello buscava construir um espaço onde pudesse divulgar e aplicar suas ideias relativas ao urbanismo nesta instituição.

\section{0 Centro de Pesquisas e Estudos Urbanísticos}

Na FAUUSP, Anhaia Mello dirigiu a Cadeira de Urbanismo de 1952, ano em que a disciplina de urbanismo do curso de graduação foi ministrada pela primeira vez, até 1961, quando se aposentou. Previa-se que o urbanista também dirigisse o curso de pós-graduação que, contudo, não chegou a ser implantado. Entretanto, pode-se considerar que sua grande realização na nova faculdade foi a criação do Centro de Pesquisa e Estudos Urbanísticos, CPEU. Sua instalação foi prevista no artigo $6^{\circ}$ do $1^{\circ}$ Regulamento da FAUUSP de 1955 , anexo à Cadeira de Urbanismo do Curso de Arquitetura. De acordo com o regulamento, o centro de pesquisa destinava-se a:

I - a realizar pesquisas, análises e inquéritos preliminares à execução de Planos Urbanísticos parciais ou gerais; II - a organizar planos diretores para os municípios que o desejarem; III - a realizar planos e estudos relativos à habitação, uso da terra, regulamentos e programas; IV - à prática e exercício dos alunos da cadeira e do Curso de Urbanismo da Faculdade; e V - ̀̀ propaganda, educação e divulgação de forma a facilitar a solução de problemas urbanísticos (Lei $n^{\circ}$ 3.233/1955). 
O CPEU foi instalado em 1957. No mesmo ano, foram iniciados os trâmites que viabilizariam que o centro, que devia apoiar o processo de aprendizado na Cadeira de Urbanismo e contribuir para o processo de planejamento em São Paulo, iniciasse a realizar planos diretores para municípios do interior do estado. A partir de 1958, estabeleceu-se uma parceria entre o CPEU e o Departamento de Obras Sanitárias da Secretaria de Serviços e Obras Públicas do Estado de São Paulo (CPEU, 1963b, p. 07), através da qual foram assinados convênios para a elaboração de Planos Diretores para as Estâncias Hidrominerais, Climáticas e Balneárias ${ }^{26}$. Lauro Bastos Birkholz ${ }^{27}$, engenheiro arquiteto formado na Escola Politécnica em 1950, ocupava naquele momento o cargo de Diretor de Planejamento do Departamento de Obras Sanitárias da referida secretaria estadual (BIRKHOLZ \& NOGUEIRA, 1992, p. 05). O engenheiro foi então contratado pelo CPEU para exercer a função de "Coordenador entre os Departamentos de Obras Sanitárias da Secretaria da Viação e Obras Públicas e o CPEU”, ao mesmo tempo em que se tornou assistente de Anhaia Mello na cadeira de Urbanismo da FAUUSP. Com a aposentadoria de Anhaia Mello, Birkholz tornou-se o responsável pela cadeira de Urbanismo (cadeira denominada, a partir de 1963, de Planejamento), assumindo, por conseguinte, a direção do CPEU e permanecendo no cargo até a extinção do centro de pesquisa.

Desde os anos 1920, Anhaia Mello conquistara uma posição de prestígio nos meios técnico e político sem, contudo, conseguir fazer prevalecer sua posição sobre aquela da engenharia municipal (ARASAWA, 2002). Com a criação da FAUUSP em 1948 e, especialmente, do CPEU, em 1957 ele pode conquistar um espaço no qual poderia colocar em prática suas ideias urbanísticas, cerca de 30 anos após ter assumido a responsabilidade pelo ensino de urbanismo na Politécnica.

Identificamos planos desenvolvidos para quarenta e três municípios paulistas entre 1957 e 1969. O primeiro município planejado pelo CPEU foi Taubaté, ainda em 1957. A esse, seguiram-se os planos para Santa Rita do Passa Quatro (1958); Águas da Prata (1958); Socorro (outubro/1959); Serra Negra (1961); Campos do Jordão (1960); São José dos Campos (plano de 1961, publicação de 1964); Itanhaém (agosto/1961); Pinhal (1965); Amparo (1966); Litoral Norte (Ilhabela, Ubatuba, Caraguatatuba e São Sebastião, 1961), Presidente Prudente (1968); Bauru (1967); São José do Rio Pardo (1968); Igaratá (1968); Cubatão (1968)

26 A justificativa para o planejamento desses municípios era o Decreto Estadual 28.399/1957, que regulava o sistema de dotações consignadas em favor desses tipos de estâncias (CPEU, 1963b, p.07).

27 Lauro Bastos Birkholz (1917-2012) formou-se no curso de engenheiros arquitetos da Escola Politécnica em 1950, como segunda faculdade, após ter se diplomado engenheiro eletricista em 1942. Em 1951, também obteve o título de engenheiro sanitarista pela Faculdade de Higiene e Saúde Pública da USP. Desde 1945, trabalhou na Secretaria de Serviços e Obras Públicas, aposentando-se em 1976. Foi em função de sua inserção no serviço público que foi contratado pelo CPEU, em 1957, para intermediar os convênios dos planos diretores do CPEU e assistir Anhaia Mello na Cadeira de urbanismo. Com a aposentadoria de Anhaia Mello em 1961, tornou-se o responsável pela Cadeira e dirigente do CPEU, onde permaneceu até sua extinção, no mesmo ano de sua aposentadoria no serviço público estadual. Permaneceu na FAUUSP até 1987onde foi Livre Docente Contratado e não Professor Catedrático. 
e Aparecida (1969). Além desses planos, publicações sobre o CPEU feitas por seus integrantes fazem referência aos planos de Atibaia, Santo André, Jaú, São Carlos, Osasco, Ribeirão Preto, Americana, Araraquara, Sorocaba, Limeira, Botucatu, Guaratinguetá, Pindamonhangaba, Caçapava, Mogi das Cruzes, Suzano, Franco da Rocha, São Roque, Bragança Paulista, Mogi Mirim, Catanduva e Franca (BIRKHOLZ \& NOGUEIRA, 1992, p. 08 e segs.).

O CPEU também publicou Boletins tratando de temas relacionados com as experiências, fundamentos, metodologia e conceitos de planejamento territorial. Nessas publicações, é possível observar um esforço por justificar a importância do trabalho realizado, como percebemos no trecho a seguir:

O Boletim n ${ }^{\circ} 01$ do CPEU, "Elementos para o planejamento territorial dos municí-

(...) [O CPEU começou] desde logo, a desenvolver o seu programa de propaganda, educação e divulgação de ideias sôbre Urbanismo e orientando a organização de planos diretores para os municípios. (...) Entretanto, os problemas de planejamento territorial, pela sua evidente complexidade, exigiam soluções objetivas e satisfatórias. Os 435 municípios paulistas (...) estavam à espera dos trabalhos relativos à sua ordenação territorial. (...) O governo, levando em conta o alto interesse público que poderia representar a ordenação do território desses municípios, planejamento esse que, como é óbvio, traria indiretamente grandes beneficios para o próprio Estado, houve por bem estabelecer um programa, a fim de atender a esse objetivo. E ao defini-lo, sabiamente, procurou entrosar a cultura, representada pela Universidade com a técnica, na Secretaria de Viação e Obras Públicas (CPEU, 196oa, p. 02).

pios" $^{28}$, consiste em um texto de autoria de Anhaia Mello, em que é feita a defesa do Plano Diretor como instrumento de planejamento. São apresentados os procedimentos para sua elaboração, configurando-se, assim, como um manual de referência para elaboração de Planos Diretores, balizando a metodologia dos planos do CPEU.

Condizente com a defesa de um urbanismo multidisciplinar, os planos do CPEU contavam com a colaboração de diversos especialistas, entre sociólogos, geógrafos, geólogos, historiadores, dentre outros, para elaborar um amplo diagnóstico. Esses estudos eram a base para as proposições expressas no plano, que deveria ser aprovado em Lei Municipal. A perspectiva da multidisciplinaridade era tida como fundamental para o desenvolvimento do trabalho, sempre posta em evidência nas publicações do centro de pesquisa:

Esses planos tinham uma estrutura semelhante e adotavam a metodologia estabe-

(...) reunindo especialistas de outros institutos universitários o Centro está não só promovendo a formação do verdadeiro espírito universitário, como também beneficiando-se da contribuição valiosa para o desenvolvimento e aperfeiçoamento de planejamento territorial (CPEU, 1960a, p. 04).

28 Apesar de editado em 1963, a sua publicação original se deu em 1957, coincidindo com o início das atividades do CPEU. 
lecida por Anhaia Mello, que compreendia as fases de Diagnóstico, de elaboração do Plano Diretor, que deveriam ser seguidas pela realização de Planos Executivos para um período de cinco anos e de um trabalho de "formação da consciência urbanística da população", que cumpria função da "conquista da opinião pública". Coerente com a proposta de Anhaia Mello, uma das primeiras medidas tomadas quando da realização desses planos era a constituição, por meio de lei, duas comissões: uma Comissão Técnica, de especialistas, e uma Comissão do Plano, que articulava membros da "sociedade civil" do município. Esse órgão consultivo era responsável por estabelecer o diálogo entre o órgão técnico e o restante da sociedade. A designação era feita pelo poder público, pelos órgãos de classe e outras associações, o que restringia o alcance da participação popular. O objetivo, ao final do processo, é que fossem aprovadas a lei de zoneamento municipal e a do Plano Diretor.

O processo de ordenação territorial deveria ser desenvolvido em três etapas. $\mathrm{Na}$ primeira, seriam delimitados o grid circulatório (sistema de vias principais) e os cinturões verdes (green-belts). Na segunda seria desenvolvido o macrozoneamento e na terceira o microzoneamento, bem como o detalhamento da estrutura interna das unidades resultantes desse processo e de seu equipamento.

Entretanto, apesar do empenho dos profissionais ligados ao centro de pesquisa, os planos tiveram pouca efetividade prática e quase não aconteceram os desdobramentos previstos para "a continuidade do planejamento", sendo que, para a maioria dos municípios, não se passou da elaboração de Planos Preliminares. Feldman observou que as estruturas de planejamento propostas pelo CPEU não foram incorporadas nas práticas da administração municipal:

O CPEU foi definitivamente extinto em 1976. Entretanto, os últimos planos de que

Na maioria das cidades onde as comissões são instaladas e os planos são elaborados, tanto a manutenção da estrutura do setor de planejamento como a implantação dos planos não se viabilizam. De modo geral, as comissões são dissolvidas e o arquiteto responsável pelo Plano é dispensado. (FELDMAN, 2005, p. 228).

se tem registro datam de 1969. De acordo com pesquisadores do CPEU, um dos principais motivos para o encerramento das atividades do centro foi a competição com escritórios particulares de planejamento, que levou à pressão por parte dos presidentes do Instituto de Engenharia e do IAB-SP junto ao Governo do Estado. "Não dispondo de dotações próprias para a realização de seus trabalhos, [o CPEU] valia-se dos recursos obtidos dos trabalhos de planejamento" (BIRKHOLZ \& NOGUEIRA, 1992, p. 10). Esse depoimento coincide com a análise feita por Feldman acerca do advento das empresas de consultoria que se consolidaram juntamente com a figura do arquiteto-planejador (2005, p. 229). Ao mesmo tempo, apontou-se a questão da Reforma Universitária de 1969, quando foram extintas as cátedras e a organização da pesquisa foi reformulada, inviabilizando a manutenção do Centro tal qual previsto na Lei 3.233/1955. Internamente à FAUUSP, o modo de trabalho do CPEU parece ter sido objeto de conflitos. Na visão dos profissionais do CPEU, foi a partir do Fórum de 68 que o centro entrou em sua fase descendente (BIRKHOLZ \& NOGUEIRA, 1992, p. 10). 


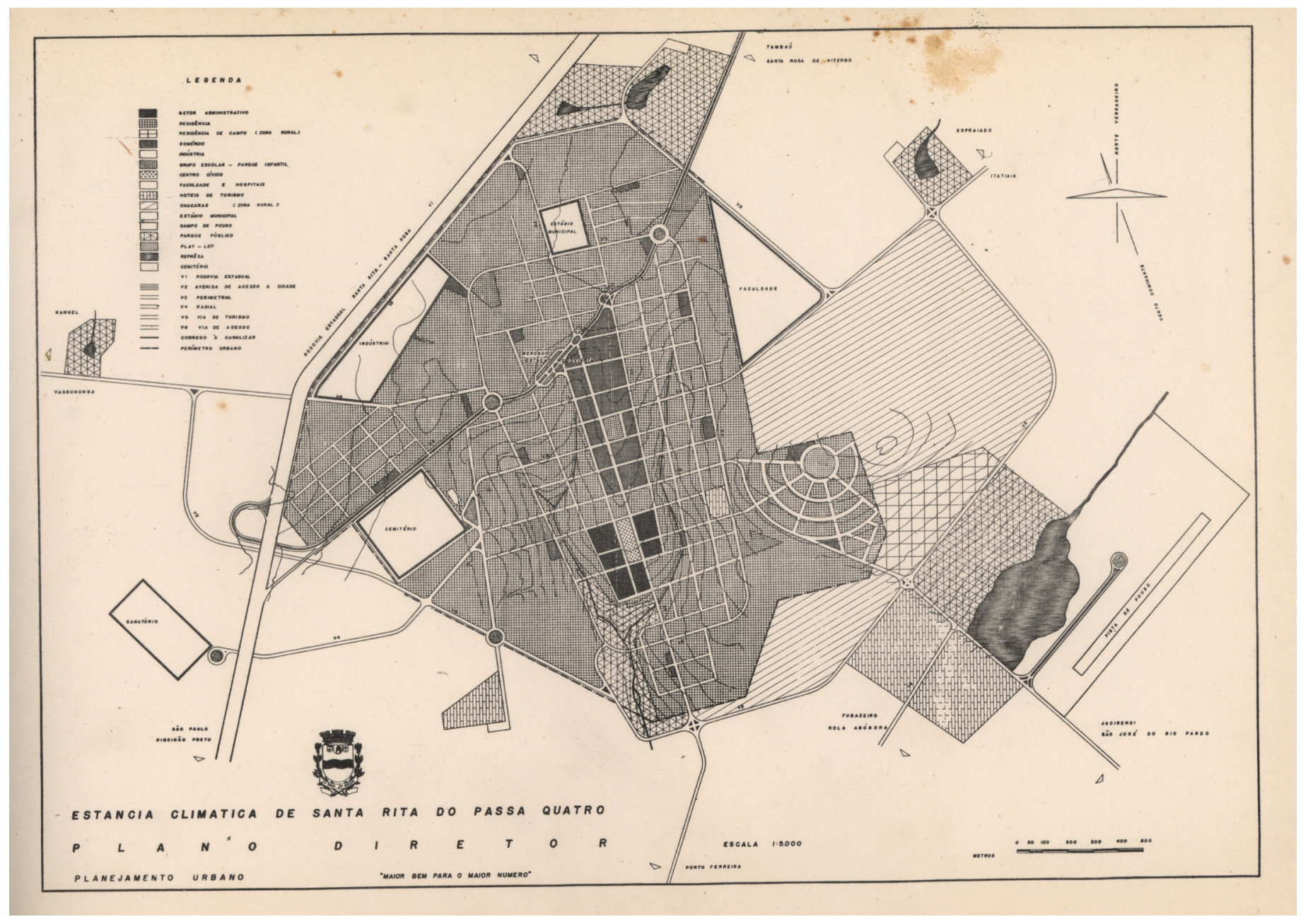

Figura 5 - Carta propositiva do zoneamento para o Plano Diretor de Santa Rita do Passa Quatro, realizado pelo CPEU em 1958.

Ainda que atualmente o CPEU seja pouco lembrado na FAUUSP, ele foi uma parte importante da estratégia de construção de um lugar de autoridade para o urbanismo de Anhaia Mello dentro da USP. Depois de sua criação, enquanto esteve à frente de sua direção, todas as manifestações do docente, fosse para a Congregação da Escola Politécnica, para os professores da faculdade ou para fora da universidade eram emitidos em folhas timbradas do CPEU, indicando o lugar de onde o urbanista falava ${ }^{29}$. 


\section{CAPÍTULO 3}

Artigas e a formação do campo de arquitetura em São Paulo 
1. A Formação (1932-1939)

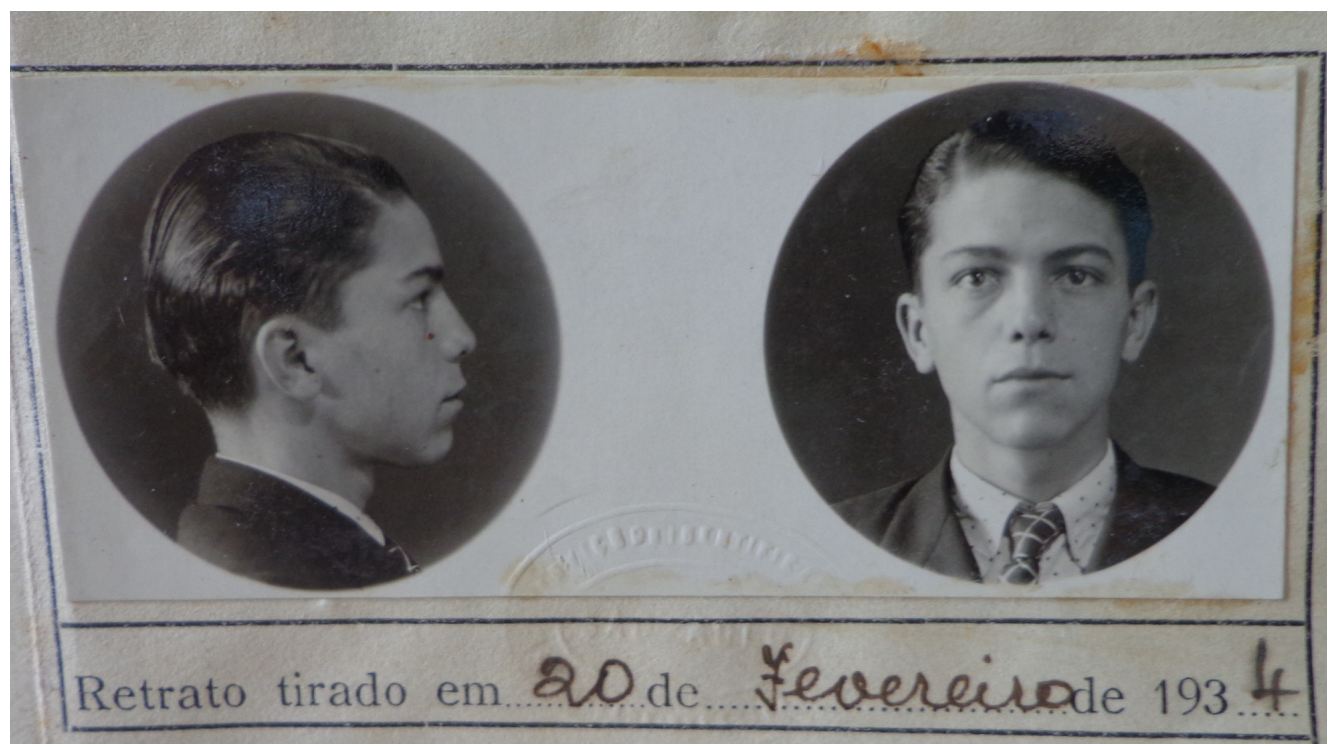

Figura 6 - Retrato de Artigas em sua Carteira de Identificação, em 1934.

João Batista Vilanova Artigas nasceu em Curitiba, no Paraná, em 23 de junho de 1915. Sua família, do município de Teixeira Soares, era de origem modesta, porém em ascensão social, de modo que, além dele próprio, todos seus irmãos também cursaram o ensino superior (GABRIEL, 2003, p. 19).

Em 1932, ingressou em Engenharia Civil na Escola de Engenharia do Paraná, onde estudou durante os dois primeiros anos. Em 1934, transferiu-se para o curso de engenheiros civis da Escola Politécnica, que, naquele ano, passava a vincular-se à recém-fundada Universidade de São Paulo (Decreto $n^{\circ}$ 39, de 03 de janeiro de 1934). Porém, em 1935, matriculou-se em cadeiras do curso de engenheiros arquitetos, para o qual se transferiu definitivamente em 1936, diplomando-se em 1937. A seguir, estão relacionadas as disciplinas e cadeiras seguidas pelo estudante no curso de engenheiros arquitetos. 
Tabela 02 - Disciplinas do curso de engenheiros arquitetos da Escola Politécnica cursadas por Artigas

\begin{tabular}{lll} 
Nome da Disciplina & Docente responsável & Ano do curso \\
\hline Composição Geral e Urbanismo & Anhaia Mello & I935 a I937 \\
\hline História da Arquitetura & Alexandre Albuquerque & I936 \\
\hline $\begin{array}{l}\text { Economia Política, } \\
\text { Contabilidade Geral e Especial }\end{array}$ & Não identificado & I937 \\
\hline Desenho de Perspectiva & Francisco Prestes Maia & I935 \\
\hline Desenho de Composição & Felisberto Ranzini & I935 a I937 \\
\hline Oficinas & Não identificado & I935 a I937
\end{tabular}

Fonte: Boletim do aluno, Arquivo Histórico da Escola Politécnica

No que se refere ao seu desempenho como estudante, Artigas foi aprovado plenamente em todas as matérias, tendo sido aprovado "plenamente com distinção" na aula de Desenho de Composição Geral do quinto ano, quando obteve média 10. Na cadeira a cargo de Anhaia Mello, as médias para os cursos do $3^{\circ}, 4^{\circ}$ e $5^{\circ}$ anos foram, respectivamente, de 8.1, 8.0 e 8.5, tendo, todavia, obtido notas 9 e 10 em alguns exames parciais. No curso ministrado por Alexandre Albuquerque, sua média foi 7. Na Cadeira de Economia Política, Contabilidade Geral e Especial, obteve média 7.2. Nas aulas de Oficinas, obteve média 9.5 e na de Desenho de Perspectiva, 7.5.

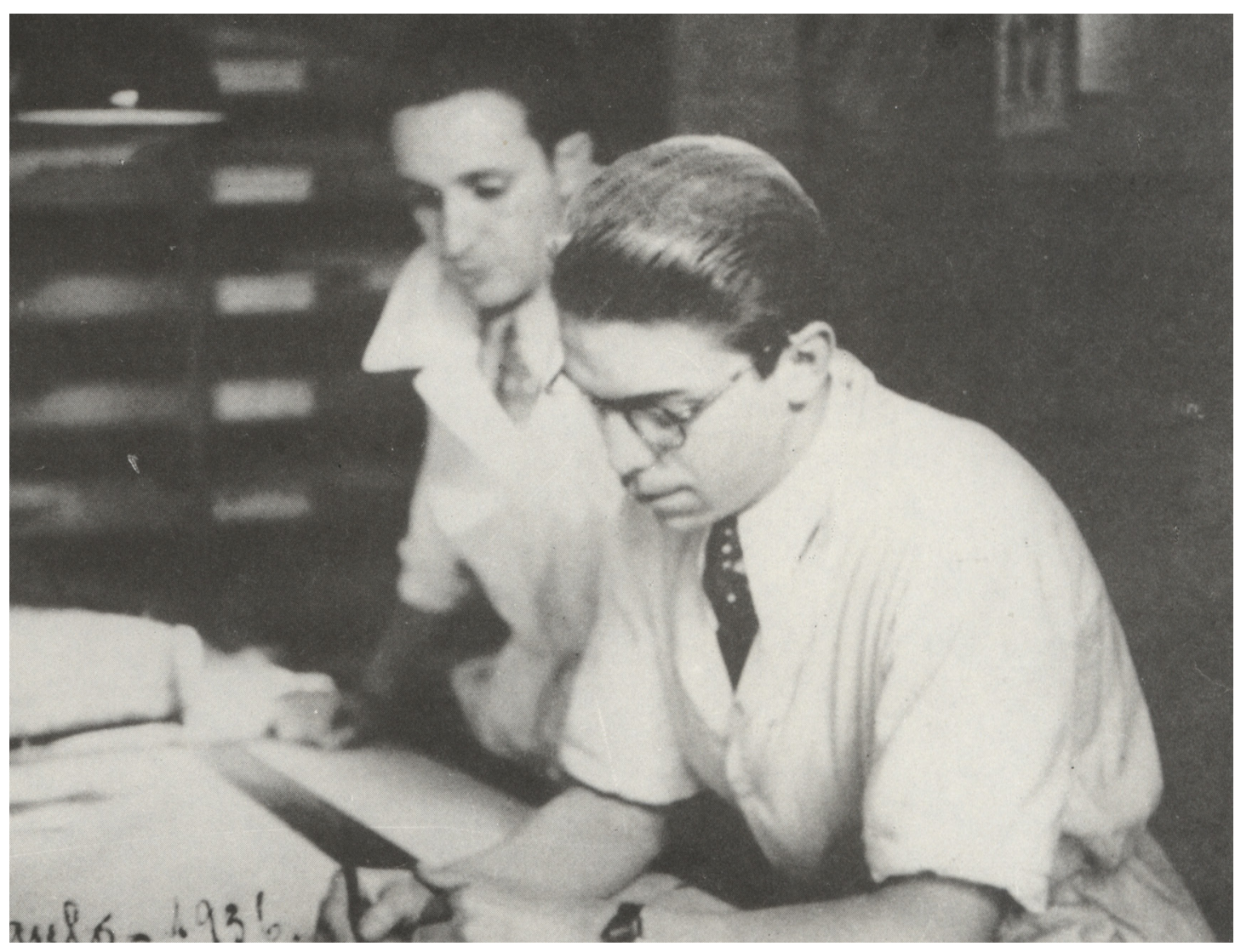

Figura 7 - Artigas na Escola Politécnica, em 1936. 


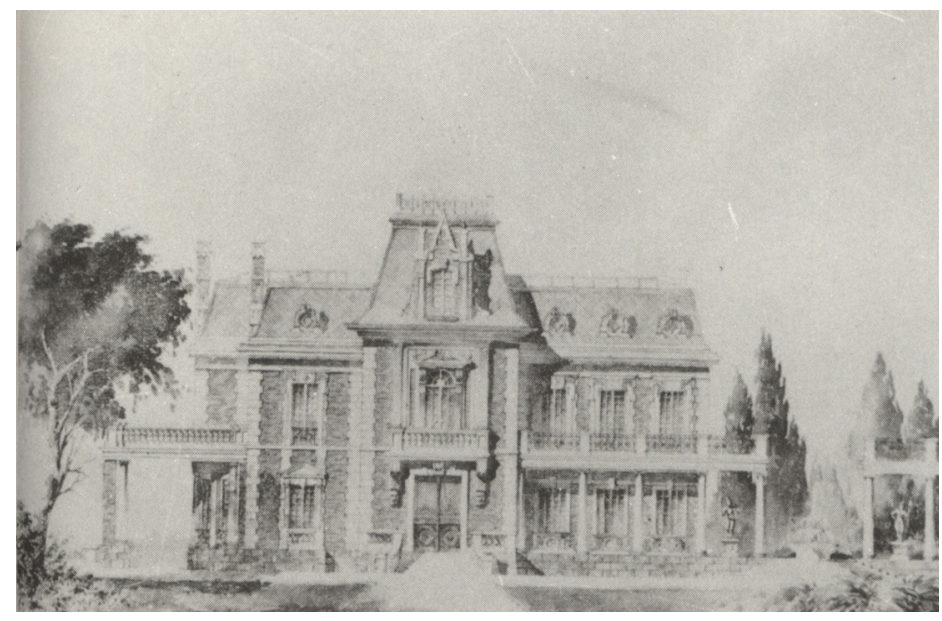

Figura 8 - Trabalho do estudante do curso de engenheiros arquitetos, entre 1933 e 1937.

Como é possível observar, os docentes com os quais Artigas teve contato mais duradouro durante sua formação foram Anhaia Mello e seus assistentes. Também foi na sua cadeira, bem como na aula de Desenho de Composição Geral a ela atrelada que o estudante obteve seus melhores resultados. A influência de Anhaia Mello sobre os estudantes do curso de engenheiros arquitetos da Escola Politécnica, bem como o seu papel crucial para a estruturação e viabilização do curso de Arquitetura e Urbanismo foram assinaladas em diversos depoimentos de Artigas. A Sylvia Ficher, o arquiteto contestou que Anhaia era, sem dúvida, a figura dominante do curso de engenheiros arquitetos, o docente que "fazia a cabeça" dos estudantes (ARTIGAS, 1982, s/n). Segundo ele, "Quando entrei na Poli já existiam duas figuras: a do Prestes Maia e do Anhaia Mello. Os outros eram um pouco marginais, mesmo o Alexandre [Albuquerque] ficava meio na marginalidade" ${ }^{1}$ (idem, ibidem).

Acerca da postura de Anhaia Mello como docente e de sua influência sobre sua própria formação, o arquiteto afirmou que: "Anhaia Mello só tratava de questões de urbanismo. A preocupação teórica não era com a estética do edifício, porém com a problemática da cidade (...)" (ARTIGAS, 1982, s/n). Tanto que, nas disciplinas de Composição, Artigas afirmou que esta:

(...) era abandonada para os italianos artesãos, que o escritório do Ramos de Azevedo trouxe para o Brasil: Henrique Vio, Felisberto Ranzini. (...) A gente compunha o que bem queria. Tirava as pranchas do Morand, francesas, que tinha lá na Escola, via como é que fazia um palácio, mais ou menos (ARTIGAS, 1982, s/n) ${ }^{2}$.

1 É interessante que Artigas apresente Anhaia Mello e Prestes Maia como as duas figuras mais marcantes do curso de engenheiros arquitetos, considerando que dentro da Escola Politécnica, Prestes Maia era um "professor de aula". Isto é, não era catedrático e ministrava um curso (desenho) que devia subsidiar o trabalho das demais cadeiras. Portanto, no âmbito da Poli, a posição de Prestes Maia era menor, do ponto de vista institucional. Ainda assim, é possível que tenha sido um docente influente, especialmente por sua experiência como urbanista do setor público e, depois, como prefeito (1938-1945). Pode também tratar-se de uma leitura a posteriori construída por Artigas.

2 Enrico Vio foi contratado em 1913 como professor de aula de "Desenho a mão livre e geométrico elementar”, do curso preliminar da Escola Politécnica, lecionando-a até 1935. Com a criação da 
Na perspectiva de Artigas, o discurso de Anhaia Mello correspondia a uma crítica à Light, que formara "a cidade a partir de seus interesses suspeitos" (idem, ibidem). Essa forma de abordar o urbanismo, que na visão do arquiteto tinha um objetivo "descolonizador" aproximava os dois profissionais:

E eu apanhei, mais tarde, para defender por outro ângulo a mesma temática que ele defendia - a da independência da cultura nacional - pelo lado de cá da estética, enquanto ele fazia a defesa da independência nacional pelo lado do espaço (ARTIGAS, 1982, s/n).

É possível que essa imagem de Anhaia Mello tivesse por intuito dar significado à própria trajetória de Artigas. Outra afinidade que pode ser localizada entre o mestre e o discípulo é o apreço demonstrado pelo ensino como "catequese cívica". Esta ideia permeia os discursos de Anhaia Mello sobre urbanismo e, para ele, estaria baseada na "conquista da opinião pública" de sua "árvore do urbanismo". Também Artigas a recuperou no elogio que fez aos seus mestres desde o secundário, passando por Anhaia Mello, e a reivindicava para o seu próprio trabalho docente:

Eu vejo no Anhaia dessa época um reflexo de meus velhos professores de ginásio (...) porque o Anhaia tinha consigo um pouco daquele ardor libertário daqueles polemistas que me ajudaram no curso secundário. O Anhaia era, nesse tempo, um homem que vociferava contra a Light e denunciava veementemente o jeito de a Light explorar a energia elétrica dentro do Estado de São Paulo, decerto fazia campanhas enormes para nós, estudantes, pelo menos no ambiente fechado no ensino da Cadeira de Urbanismo, ajudou bastante (...) [a] alargar a vista sobre os problemas da conjuntura brasileira, da situação política nacional (...) (ARTIGAS, 1982, s/n).

Além da formação de Artigas dentro da Escola Politécnica, vale a pena retomar outros espaços frequentados pelo estudante durante os anos 1930. Muito provavelmente a convite de Alexandre Albuquerque, que também lecionava na Escola de Belas Artes de São Paulo, Artigas frequentou, entre 1936 e 1939, o curso de modelo vivo daquela instituição. Lá, o arquiteto pode conviver com artistas ligados ao Grupo Santa Helena. Esse grupo reunia artistas de origem social modesta, muitos dos quais autodidatas ou formados no Liceu de Artes e Ofícios, concentrados em ateliês improvisados no Palacete Santa Helena, no centro de São Paulo, onde também estava sediada a entidade representativa dos sindicatos

2 USP, tornou-se professor de Desenho para as séries do "Colégio Universitário" criado naquela ocasiçao (FICHER, 2005, p. 88). Felisberto Ranzini foi professor de Composição Decorativa, que passou a chamar-se "Composição Geral e Decorativa. Modelagem” em 1926 e "Desenho Geral de Composição. Modelagem” a partir de 1932, oferecida para os segundo e terceiro anos do curso de engenheiros arquitetos (idem, p. 202). 
operários $^{3}$ (ZANINI, 1983, p. 585). Todos esses artistas vincularam-se à Família Artística Paulista, criada em 1937. Esse movimento promoveu três exposições, sendo duas em São Paulo (1937 e 1939) e uma no Rio de Janeiro (1940).

Foi também nas aulas de modelo vivo que Artigas conheceu sua futura esposa, Virgínia Camargo e que, provavelmente, iniciou sua formação política no âmbito dos princípios do Partido Comunista Brasileiro, PCB. De acordo com Gabriel (2003, p. 30), essa vivência na Belas Artes permitiu que Artigas se diferenciasse da cultura politécnica sem que isso o conduzisse a uma ruptura. Assim ele pode tomar contato com outras dimensões do pensamento, que encontraram rebatimento no campo da arquitetura, levando-o inclusive a ler revistas americanas e estudar a obra de Wright. A respeito dessa experiência, Artigas afirmou que:

(...) isso me fez tomar contato estreito com o movimento de artes plásticas em São Paulo, pela base, é claro, pelo pessoal que se formava, e de que maneira só eu sei (...) Quando eu me formei (...) arquiteto já estava em contato com o movimento artístico paulista, bem estreito. Em suma, eu creio que o que mais me influiu mesmo, para a minha carreira de arquiteto, foi muito menos, (sic) um curso de arquitetura que eu pudesse ter feito. (ARTIGAS, 1982, s/n).

Em 1936, Artigas também passou a estagiar no escritório de Oswaldo Bratke e Carlos Botti, iniciando sua experiência profissional. Thomaz (1997, p. 52) acredita que essa vivência junto a Bratke foi decisiva para a prática posterior de Artigas, do ponto de vista do rigor técnico e profissional. Foi uma oportunidade de aproximar-se da execução de obras, uma vez que se tratava de uma construtora, permitindo-lhe adquirir maior conhecimento sobre materiais e técnicas construtivas.

A partir de 1937, Artigas deu início à prática profissional liberal através da sociedade com o colega engenheiro civil Dúlio Marone e, paralelamente, em 1939, trabalhou por um curto período na Secretaria de Viação e Obras Públicas com projetos urbanos, por indicação do seu professor Alexandre Albuquerque.

***

É possível que a aproximação com o grupo de artistas da Família Artística Paulista tenha colocado Artigas em contato com Gregori Warchavchik, em cuja parceria foram apresentados projetos para os concursos para o Paço Municipal e para a Praça da República, ambos de 1939. No mesmo sentido, Gabriel (2003, p. 33) avaliou que foram a produção de Artigas junto à Família Artística Paulista e a adoção de um desenho arquitetônico diferenciado que indicaram ao arquiteto ucraniano a existência de um talento. O próprio Artigas, em depoimento, afirmou que foi procurado por Warchavchik devido à sua fama de bom desenhista, conquistada, segundo ele, na Secretaria de Viação e Obras Públicas (THOMAZ, 1997, p. 57).

3 Pertenciam ao Grupo Santa Helena os pintores Francisco Rebolo Gonsales, Mário Zanini, Aldo Bonadei, Alfredo Volpi, Clovis Graciano, Fulvio Pennacchi, Manoel Martins, Alfredo RulloRizzotti e Humberto Rosa. Todavia, outros artistas também frequentavam os ateliês desses pintores. 

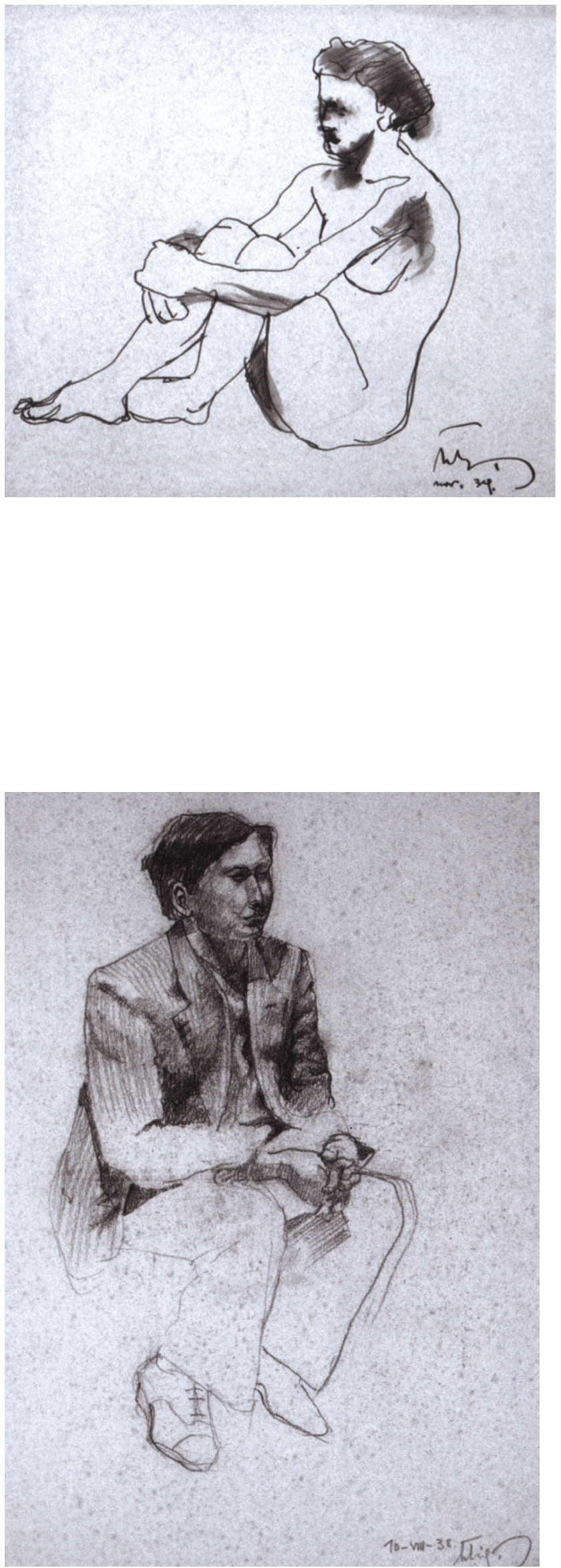

Figura ıo - Artigas. Mulher nua, sentada segurando os joelhos, novembro de 1939. Curso livre de desenho da Escola de Belas Artes de São Paulo.
Figura 9 - Artigas. Homem Sentado, 10 de agosto de 1938.

Curso livre de desenho da Escola de Belas Artes de São Paulo. 
Thomaz (idem, p. 59) chamou a atenção para o fato de que nem Artigas nem Warchavchik apresentavam experiência prévia na concepção de projetos de escala urbana, como foram aqueles para a Praça da República e para o Paço Municipal. No Concurso para o Paço Municipal, os autores extrapolavam a área prevista, que se limitava à Praça Clóvis Bevilacqua, incluindo também a Praça da Sé, compondo uma "grande praça cívica" em função da qual deveria ser demolido o Palacete Santa Helena, frequentado pelo grupo de artistas com os quais Artigas travara amizade. O projeto de Warchavchik e Artigas não foi implementado nos anos 1930, mas essa ideia foi precursora do que viria a acontecer nos anos 1970, quando em função das obras do Metrô a praça da Sé e a Praça Clóvis Bevilacqua foram unidas. A proposta previa também a reformulação do setor viário, criando passagens subterrâneas que liberavam a praça do tráfego intenso (idem, p. 60). Do ponto de vista arquitetônico, a proposta apresentada aproximava-se da linguagem Art-Déco. Com este projeto, Artigas e Warchavchik obtiveram o segundo lugar.

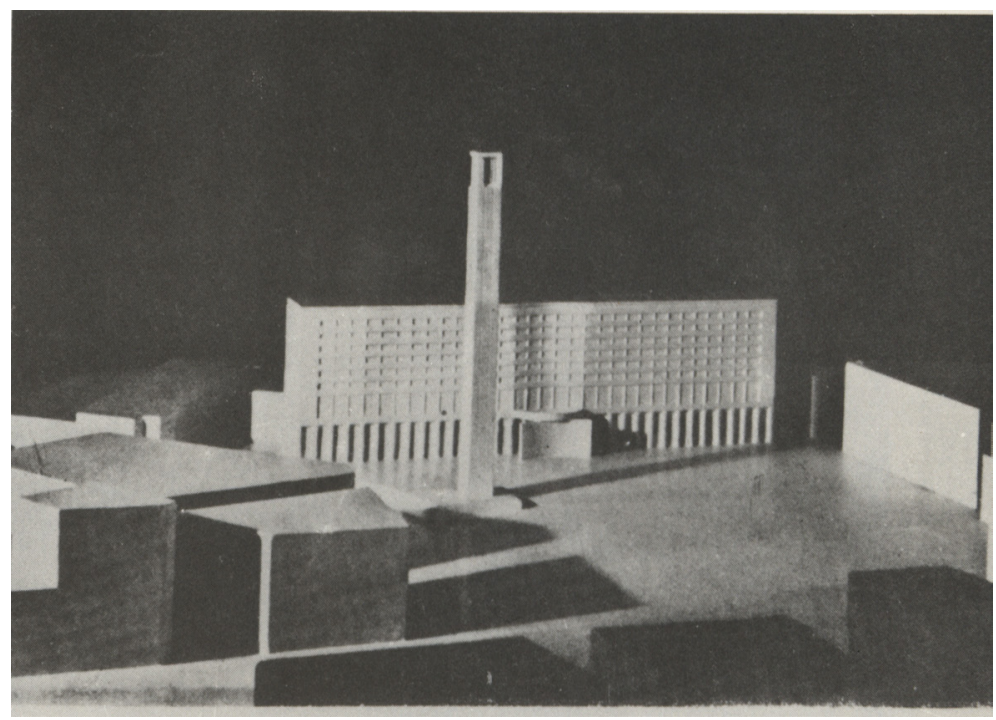

Figura II - Maquete do projeto para o Paço Municipal - Artigas e Warchavchik, 1939

No concurso para a remodelação da Praça da República, promovido pela Prefeitura Municipal de São Paulo, pouco tempo após o concurso para o Paço Municipal, os arquitetos foram desclassificados em virtude da linguagem da apresentação, que mesclava desenho e colagem de fotografias (THOMAZ, 1997, p. 61).

Em depoimento de 1982, Artigas frisou que a união com Warchavchik não fora devida a um interesse seu por ampliar seus conhecimentos sobre arquitetura. Todavia, observando sua condição de jovem profissional, que até então realizara poucos projetos, quase todos baseados em "variações ecléticas" ao gosto de seus clientes, parece duvidoso acreditar que não houvesse um objetivo de fortalecimento profissional nessa parceria. Thomaz (1997, 
p. 13) defendeu que foi através do arquiteto ucraniano e de sua biblioteca, inclusive, que Artigas tomou conhecimento de trabalhos de Frank Lloyd Wright e Le Corbusier. O arquiteto paranaense, entretanto, opunha-se veementemente a essa leitura de sua trajetória:

Ah, eu conhecia muito bem [Le Corbusier] mas não via Warchavchik, mas porque eu tinha mais cultura que eles todos. O Warchavchik era um imbecil, não sabia nem falar o português. A Dona Bárbara, mãe do Jacob [Ruchti] me disse que ele falava russo pessimamente (ARTIGAS, 1982, s/n).

Posteriormente, Artigas deu a entender que a separação de Warchavchik estava relacionada a uma divergência de posição com relação "moral construtiva” ${ }^{4}$. Todavia, consta um documento sobre uma sociedade provisória entre os dois no memorial do concurso para professor titular da FAUUSP, em 1984 (GABRIEL, 2003, p. 33). Ainda assim, Gabriel avaliou que essas divergências parecem ter surgido a posteriori, observando que a mesma solução arquitetônica que era objeto de sua crítica (adoção de telhado comum sob platibanda) foi empregada na residência Giulio Pasquale, de 1939. Segundo o autor, possivelmente, não houve um estremecimento, à época, entre os dois arquitetos, mas vencida a necessidade imediata de ganhar projeção no meio profissional, Artigas deu curso à ambição de independência, de conquista de autonomia ${ }^{5}$.

\section{Atuação Profissional (1940-1962)}

\subsection{0 assistente de Anhaia Mello}

No início do ano letivo de 1940, Artigas foi designado para exercer o cargo de $2^{\circ}$ adjunto da Cadeira de Anhaia Mello. De acordo com a carta redigida pelo catedrático, o as-

4 "Moral construtiva" é um conceito que Artigas passou a defender a partir de 1939-40. Gabriel estabelece um paralelo entre essa moral construtiva e a "modesta consciência técnica com que a escola de São Paulo [a Família Artística Paulista] se afirma”, nas palavras de Mário de Andrade (1972, GABRIEL, p. 49). Isso revela a importância do convívio com aquele grupo de artistas para sua formação.

5 Para Gabriel, Artigas, em toda sua carreira, construiu seu caminho ambicionando a conquista de autonomia e de reconhecimento. Diante disso, suas alianças foram sempre provisórias, devido a necessidades ainda não transpostas e desfeitas assim que possível. Finalmente, em 1944, Artigas conseguiu abrir seu próprio escritório. Nele, seus associados, dentre os quais Carlos Cascaldi foi o mais duradouro, sempre mantiveram uma relação desigual com o arquiteto, Artigas assumindo o controle do processo criativo. 
sistente anterior, Afonso Iervolino fora indicado para Professor de Desenho e, não podendo acumular as duas funções, propunha que o arquiteto João Batista Vilanova Artigas, que fora "um dos mais distinctos alumnos de architectura da nossa Escola [Politécnica]" assumisse a posição vaga. Gabriel (2003, p. 32) também assinalou a possibilidade de que a indicação tenha sido influenciada pela participação de Artigas no concurso para o Paço Municipal de São Paulo junto com Gregori Warchavchik. Se isso for procedente, corrobora-se a hipótese de que já no início dos anos 1940 o catedrático estava interessado em aproximar-se de arquitetos favoráveis à arquitetura moderna.

Quando, no segundo semestre de 1941, Anhaia Mello se afastou de suas funções na Escola Politécnica para exercer o cargo de Secretário da Viação e Obras Públicas, Artigas foi designado para reger a interinamente Cadeira ${ }^{7}$. A substituição correu até o fim do segundo semestre de 1943, quando Anhaia Mello reassumiu a função ${ }^{8}$ e Artigas retornou ao cargo de $2^{\circ}$ Adjunto. No início de 1944, Artigas foi promovido a $1^{\circ}$ Adjunto da Cadeira, continuando a substituir Anhaia Mello quando este se afastava da USP9 .

Como assistente de Anhaia Mello eu não podia falar nada. Eu era seu assistente no atelier de arquitetura. Era um homem interessante, eu era seu assistente para os aspectos que se chamavam "composição". Aí eu tinha força pra orientar jovens estudantes (...). Para o lado da Arquitetura moderna. Sem que o Anhaia dissesse "não faça isso, não faça aquilo" porque ele estava interessado nas questões de urbanismo (ARTIGAS, 1982, s/n).

Na Politécnica, o papel a ser desempenhado por Artigas na qualidade de assistente da Cadeira de Composição Geral, Estética e Urbanismo consistia em acompanhar as atividades dos alunos durante o "ateliê de arquitetura". O conteúdo teórico do curso ficava a cargo de Anhaia Mello. Portanto, Artigas supervisionava as atividades práticas de composição (THOMAZ, 1997, p. 67), atribuição que lhe possibilitou, em certa medida, discutir as inovações no campo da arquitetura ao longo dos anos 1940. Em entrevista a Ficher, Artigas assinalou a sua posição subalterna diante do catedrático. Ainda assim, insistia na liberdade para tratar de arquitetura, diante da falta de interesse daquele pelo tema:

Talvez como uma forma de afirmar a ideia de que ele teria fundado o curso de arquitetura ao lado de Anhaia Mello, que fundara o urbanismo na FAUUSP, Artigas procu-

6 Carta de 28 de fevereiro de 1940, Pasta Funcional de Artigas na Escola Politécnica.

7 Ofício n D-41/674, de 02 de agosto de 1941, do diretor da Escola Politécnica, Lucio Martins Rodrigues, ao Secretário da Educação e Saúde Pública, José Rodrigues Alves Sobrinho.

8 Ofício $n^{\circ} \mathrm{D}-1053 / 43$, de 19 de novembro de 1943.

9 Por exemplo, por ocasião da licença prêmio de Anhaia Mello, no primeiro semestre de 1955, Artigas o substituiu nas funções da Cadeira $n^{\circ}$ 12, Noções de Arquitetura e Construções Civis; Higiene das Habitações; História da Arquitetura, da Escola Politécnica, conforme o Processo ${ }^{\circ}$ SP-49/1955 da Escola Politécnica, de 25 de fevereiro de 1955; carta de 26 de fevereiro de 1955 e Ofício D-368/55 de 03 de março de 1955, na Pasta Funcional de Artigas na Escola Politécnica. 
rava distinguir seu mestre do restante do meio politécnico: "jamais os engenheiros da Poli compreenderam a pregação do Anhaia [acerca de um 'urbanismo independente'], jamais" (ARTIGAS, 1982, s/n). Em seu depoimento a Sylvia Ficher, é possível constatar que o arquiteto procurou traçar uma continuidade de pensamento entre ambos. Tal continuidade residia na inquietação em buscar os "aspectos culturais vindos da independência", compartilhados por ambos e que Artigas viria a "formular politicamente" (idem, ibidem).

Após a extinção definitiva do curso de engenheiros arquitetos da Escola Politécnica, Artigas foi relotado com o mesmo cargo na FAUUSP ${ }^{10}$. Artigas pertencia à categoria de professores contratados, no cargo de Instrutor, não chegando a exercer o cargo de docente catedrático. Ainda nos anos 1980, quando Artigas reingressou ao cargo de docente após um período de vinte anos afastado da universidade, ele mantinha-se na mesma categoria, o que mudou apenas em 1984 quando, às vésperas de se aposentar, prestou o concurso para provimento de cargo de professor titular.

No período em que foi assistente de Anhaia Mello, Artigas empreendeu uma viagem de estudos aos Estados Unidos entre outubro de 1946 e novembro de 1947, com bolsa da Fundação Guggenheim. Anhaia Mello recomendou à congregação da Escola Politécnica que concedesse o afastamento ao assistente, sem prejuízo de seus vencimentos, tendo em vista a contribuição que aquela viagem poderia representar para a fundação da FAUUSP. A justificativa para a viagem era estudar modelos de ensino de escolas de arquitetura norte-americanas (apud IRIGOYEN, 2002, p. 148). Durante essa viagem de estudos, Zenon Lotufo substituiu Artigas no cargo de assistente de Anhaia Mello.

\subsection{A visão de Artigas sobre a FAUUSP}

Para Artigas, como para Anhaia Mello, a proposta de doação de um edifício para abrigar uma escola de arquitetura pelos irmãos Penteado foi fundamental para viabilizar a fundação de uma escola de arquitetura independente da Escola Politécnica. Nesse sentido, a possibilidade de criação de uma faculdade de arquitetura autônoma surgiu graças à intervenção de, em suas palavras, "latifundiários esclarecidos", membros da aristocracia cafeeira que se comprometiam com o fomento da indústria. Em entrevista a Sylvia Ficher (ARTIGAS, 1982), o arquiteto afirmou que a repercussão dessa proposta no meio politécnico tendeu a ser muito negativa, especialmente porque isso significaria a diminuição da representatividade da Escola junto ao Conselho Universitário. Assim, destacou que a iniciativa de Anhaia Mello para viabilizar o empreendimento havia sido decisiva para seu sucesso.

A FAU se justifica talvez por duas direções: primeiro porque havia uma Universidade de São Paulo criada em (...) 1934 e, segundo, porque a Escola Politécnica também começava a se desmembrar, devido à nova universidade. Ha-

10 DOSP, 18 de agosto de 1956. 
via uma tendência na Universidade para uma escola de arquitetura. E havia uma outra coisa, que era a necessidade do desenvolvimento capitalista: uma divisão do trabalho. Os cientistas sociais, os físicos para pesquisar assuntos específicos, os biólogos, antropólogos dividiram a pesquisa científica para fazer desse estado que está aqui um país desenvolvido, como de fato é, se comparado com o resto do Brasil. Não se pode ver a criação da USP, a criação da FAU e a necessidade de divisão do trabalho na pesquisa e na cultura mesmo e esquecer a condição peculiar de São Paulo dentro do Brasil. (...) Então, é nessa conjuntura econômica que se deveria ver a criação da FAU e das outras atividades de pesquisa no campo universitário (...). Esse raciocínio, eu acredito que seja o mais justo para explicar as razões da FAU. Como coincide o donativo do Penteado com a necessidade de se fazer uma arquitetura nacional, com as condições da cidade (...) (ARTIGAS, 1982, s/n).

Desse modo, a interpretação de Artigas para o contexto que viabilizou a criação da FAUUSP levava em conta uma pressão interna, ligada à criação da Universidade de São Paulo e ao processo de autonomização das disciplinas que passou a ocorrer no seio daquela instituição. Havia também uma pressão externa, referente à necessidade de divisão do trabalho no âmbito da pesquisa, tendo em vista o desenvolvimento capitalista. Uma questão de conjuntura que favoreceu esse processo foi a doação de um edifício para abrigar a nova faculdade. Como pressão externa do processo de criação da FAUUSP, Artigas também assinalou a questão do desenvolvimento econômico paulista e o processo de industrialização que se acelerava a partir daquele momento.

Conforme mencionamos anteriormente, em seus depoimentos, o arquiteto procurou frisar que, no processo de fundação da FAUUSP, Anhaia Mello teria ficado a cargo da estruturação do curso de urbanismo, enquanto ele próprio, acompanhado de outros arquitetos, mas sempre numa posição de liderança, teria levado adiante a estruturação do curso de arquitetura. Em depoimento a Ficher, o arquiteto comentou: "você veja que coisa curiosa: o Anhaia nunca foi particularmente um arquiteto de prédios, mas foi um arquiteto que orientou a arquitetura para o lado do urbanismo" (ARTIGAS, 1982, s/n).

De modo geral, esses depoimentos reforçavam o interesse predominante de Anhaia Mello pelo urbanismo e testemunhavam a importância do catedrático para a formação de Artigas e para a própria fundação da FAUUSP. Entretanto, mais do que isso, ao utilizar-se desses argumentos, Artigas sugeria que no processo de estruturação do novo curso de arquitetura e urbanismo, Anhaia Mello teria se preocupado apenas com os aspectos do urbanismo, tendo ficado a cargo de Artigas a definição do curso de arquitetura.

O Anhaia não tinha visão sobre essas coisas [de arquitetura], forçando o lado urbanístico da arquitetura - com muita razão - fez o CPEU da FAU. Quer dizer, orientou a escola muito na direção do urbanismo, que levou o debate estético a não ter significado e nos deu liberdade para buscarmos soluções (ARTIGAS, 1982, s/n) ${ }^{11}$.

11 A declaração de Artigas evidencia a não-unidade do campo no contexto de fundação da FAUUSP. 
Para Artigas, Anhaia Mello se diferenciava dos demais engenheiros politécnicos que se dedicaram ao urbanismo por assumir um interesse mais "cultural do que técnico". Todavia, não se pode ignorar que o próprio Anhaia Mello defendia o urbanismo como um problema de ordem técnica e desvinculado da política. O que o diferenciava de seus colegas era que até então, os planos e projetos urbanísticos tendiam a partir de soluções de infraestrutura. Dentre exemplos paradigmáticos, podemos citar a proposta de Victor da Silva Freyre para o Vale do Anhangabaú (1911). No Plano de Melhoramentos do Tietê proposto por Saturnino de Brito nos anos 1920, o engenheiro propunha uma estruturação viária associada ao sistema de drenagem da várzea do rio, visando o controle das cheias. Em 1930, Prestes Maia apresentou o Plano de Avenidas, com um modelo de estruturação urbana apoiado em um sistema viário rádio-concêntrico. Anhaia Mello propunha um paradigma de urbanismo distinto, que não mais partia das infraestruturas urbanas, mas do plano diretor, regulador do uso e ocupação do solo, do zoneamento e de propostas setoriais que iam desde o sistema viário aos equipamentos públicos necessários no âmbito da educação e da saúde. A esse respeito, Artigas afirmou:

Prestes Maia de um lado, Anhaia do outro. O urbanismo do Prestes Maia: o edifício e as ruas. Do lado de cá, o urbanismo das ideias, que foi encontrar, mais tarde, na sociologia paulista, o estudo do espaço ainda que até agora muito saltitante e inocente, mas que já começava a aparecer com suas características. Agora, veja o que a FAU representou nesse momento: é a ponte entre isso e o resto da universidade, para que os problemas do espaço pudessem ser tratados sob o ponto de vista técnico - na linha prestemaiana - e cultural na linha anhaiana - mas também na linha do Artigas - da independência nacional - na fusão dos dois aspectos (ARTIGAS, 1982, s/n).

Segundo o docente, a FAUUSP foi muito marcada pela presença do ensino politécnico em seus primeiros anos: "o arquiteto formado até 1962 era um arquiteto que tinha conhecimento de tecnologia em paralelo ao dos engenheiros de construções" (ARTIGAS, 1982, s/n). Artigas afirmava que, naquele processo, havia procurado deixar algumas questões importantes para serem discutidas e implementadas posteriormente, a fim de viabilizar algumas conquistas. Dessa forma, era preferível criar uma faculdade de arquitetura e urbanismo fora da Escola Politécnica, "para montar a figura do arquiteto" (idem, ibidem) ainda que muito da estrutura politécnica permanecesse: "E eu dizia naquela ocasião: qualquer caminho nos serve, vamos tocar nas questões do ensino mais tarde. Fui fazê-lo em 1962 "12 (idem, ibidem). A mesma lógica de pensamento foi apresentada aos estudantes da faculdade em 1956, quando ele se queixou de que a oposição daqueles ao regulamento quase inviabilizara sua aprovação (ARTIGAS, 2004, p. 65). Ainda na reforma de 1962, o arquiteto afirmou que ela se restringiu ao departamento de projeto, sendo que os departamentos de história e de tecnologia viriam a fazê-la posteriormente (ARTIGAS, 1982, s/n). É interessante observar que Artigas insistia em reiterar que ele era o próprio autor da refor-

12 Observe-se que a reforma de 1962 foi realizada em seguida à aposentadoria de Anhaia Mello, que ocorreu em setembro de 1961. 
ma, chegando a eclipsar a colaboração de outros docentes que tiveram um papel importante naquele processo, como Carlos Milán, Roberto Cerqueira César, Marlene Picarelli, Lúcio Grinover, Hélio Duarte, dentre tantos outros. Em sua visão:

A reforma de 62 é uma reforma que chuta, joga no lixo de dentro da FAU todos os restos acadêmicos da Belas Artes do Rio de Janeiro que estavam lá dentro. Desde arquitetura até desenho a mão livre, desenho geométrico, arquitetura de interiores e uma série de coisas (...). A reforma de 62, que eu muito me orgulho de ter feito, centraliza o atelier em torno de quatro sequencias. E eu fiz do desenho industrial, do estudo do objeto, da comunicação, do desenho (...) artístico, da construção, o desenho do edifício, um planejamento em torno de urbanismo e paisagismo. Foi para um plano espacial maior, fazendo do edifício como objeto, domínio e objeto voltado pra indústria e mais a comunicabilidade como linguagem. Então, um atelier racional. Aqui nesse atelier ninguém ensina mais desenho à mão livre e desapareceu a cadeira de desenho. O desenho passou a ser um meio e não um fim. (...) Daqui para os outros departamentos foi muito difícil, em primeiro lugar porque você verá que a reforma de $6_{2}$ não pode atingir nem a história nem a tecnologia. Eles simplesmente não me deram ouvidos. E só prevaleceu o atelier. Novamente, a minha política "está bem, já chega, mais tarde nós vamos ver essas coisas" (ARTIGAS, 1982, s/n).

A partir de 1963, a realização de fóruns de debate sobre o ensino na FAUUSP tornou-se uma pratica recorrente. Desses, o mais contundente foi o de 1968, ano em que o novo edifício da FAUUSP na Cidade Universitária estava em vias de conclusão. Procurava-se avaliar a implantação da reforma do início da década e reconduzir o ensino aos objetivos que haviam então sido estabelecidos. Artigas, que participou das discussões, mostrava-se confiante quanto às possibilidades que se apresentariam com a nova sede da faculdade. $\mathrm{O}$ arquiteto dirigiu uma crítica ao grupo de disciplinas de planejamento, que segundo ele não mostravam apenas as insuficiências do curso, mas:

(...) antes de tudo que a metodologia para aplicação e organização dos planos urbanísticos é ainda muito confusa. Por duas razões: primeiro porque a cidade foi, como natureza propriamente humana, profundamente trabalhada (e ainda é) pelo pensamento utópico (pelo socialismo utópico hoje). Depois, e por razões decorrentes da anterior, a técnica resumiu-se à chamada engenharia municipal, que deixou grandes contribuições mas como engenharia resumia-se a cumprir no fundamental o imediato, etc. (a serviço da estrutura de domínio, etc.). A passagem das propostas utópicas para projetos possíveis e da engenharia municipal para uma técnica audaciosa, nova e emancipadora constitui como que a tomada de consciência para o urbanista conseqüente, da qualidade do mundo em que vivemos. (ARTIGAS, 2001, p. 57).

Para Artigas, o curso de urbanismo da FAUUSP poderia ser melhorado com a mudança de orientação dada ao CPEU, traçando-se um programa a partir da experiência brasileira. Segundo ele, o centro de pesquisa havia se transformado num "escritório de planos 
para cidades do interior", abandonando sua "verdadeira finalidade”, a pesquisa urbanística. Prova disso era a ausência da FAUUSP na discussão do Plano Urbanístico Básico de São Paulo, PUB ${ }^{13}$, que acabava de ser concluído. O docente propunha o desenvolvimento de pesquisas próprias, voltadas para a escola e para a atividade profissional, em diálogo com os estudantes, contribuindo e aproveitando o Ateliê Interdepartamental. Além disso, citava a necessidade de articular o centro de pesquisa com o grupo de construção a fim de restituírem uma "técnica" de construção para as cidades. O CPEU deveria ter um plano e clareza dos seus objetivos, de modo a não justificar-se com "uma atividade burocrática sem destino" mas efetivamente:

Contribuir para a modificação da atual técnica urbanística (engenharia municipal) e abandonar a temática utópica (ajudando a criar uma "teoria" brasileira de "urbanização" - anticampo - e decorrente da luta contra o subdesenvolvimento e a favor da industrialização) (ARTIGAS, 2001, p. 63).

A diferença de posições entre o corpo docente no Fórum de 1968 pode ser observada nas Atas da Congregação da FAUUSP, instituída naquele ano. Em 16/01/1969 (13 a Sessão da Congregação), o professor Paulo Ferraz de Mesquita propôs uma moção a ser apresentada ao Conselho Universitário, na qualidade de representante do Departamento de Ciências Aplicadas. O docente queixava-se da postura do professor Artigas no processo de debate do Fórum de 1968, que, segundo Mesquita, propunha a extinção da Cadeira de Geometria Descritiva, pela qual ele era responsável, além da alteração de outras disciplinas técnicas, como a de topografia.

O fato principal é que o professor Artigas e outros fizeram expor no saguão da FAU, em dias de agosto de 1968, uma série de pranchas murais por ele organizadas, subjetivamente, apresentando uma utopia baseada em mera dialética ultrapassada, excluindo, desligando ou juntando matérias de ensino a seu bel prazer, como se isso valesse para atender as resoluções do Fórum de Debates realizado em junho e julho do mesmo ano, quando, na realidade, aquele Fórum decidiu que "a FAU se organiza apoiada em bases científicas" e que foi esclarecido que "a Ciência é encontrada quando e onde há objetos (concretos ou abstratos) de durações comparáveis e o seu valor reside em comparar durações... etc.", conforme consta na ata da sessão plenária daquele Fórum de Debates, realizada aos 21 do mês de junho de 1968 (...). (1 ${ }^{\circ}$ Livro de Atas da Congregação da FAUUSP, p. 24).

De acordo com a denúncia de Mesquita, essa discussão levara estudantes de $1^{\circ}$ ano a se recusarem a assistir às disciplinas em questão no segundo semestre de 1968. O docente apresentou então uma carta que deveria ser lida no Conselho Universitário fazendo ataques às atitudes de Artigas. Mesquita opunha a "ciência em seu sentido unívoco" a uma

13 Artigas mencionou que a correção da orientação do CPEU foi tentada na reforma de 1962, mas foi atrapalhada pelos eventos de 1964 (2001, p. 63). 
"dialética do começo do século XX e do fim do século passado". O professor não esclareceu, em sua fala, de que tratava a "dialética" empregada por Artigas, mas a expressão, reiterada sucessivamente em sua moção, ao lado de termos como "tumultuar", "filosofias fáceis e arruaceiras" sugerem que se estava insinuando que se tratava de uma atitude "comunista". O professor Mesquita empregava uma linguagem alinhada com o discurso dos militares, que estavam no poder, de modo a incriminar Artigas por sua postura no Fórum de 1968. A publicação da moção não foi aprovada pela congregação, sob argumentos de professores como Juarez Brandão Lopes e Flávio Motta, de que se tratava de uma manifestação pessoal do professor Mesquita e que ao Conselho Universitário deveriam ser levadas manifestações do Colegiado. O presidente da sessão, vice-diretor Victor Froilano Bachman de Mello, politécnico como Mesquita, também se opôs à proposta. Ainda assim, Artigas, que participava da Congregação como representante dos professores contratados desde a primeira sessão, não voltou a constar na lista de presentes nas sessões que se sucederam. E pouco tempo depois, foi aposentado compulsoriamente com seus colegas Paulo Mendes da Rocha e Jon A.V. Maitrejean. Esse evento não foi tema de debate da congregação da FAUUSP. Apenas, na décima sexta reunião da Congregação, em 26/09/1969, foi aprovada a designação do professor Hélio de Queiroz Duarte para ocupar o lugar que se vagou com a aposentadoria do Professor João Batista Vilanova Artigas na disciplina de Projeto IV, cumulativamente com seu cargo de professor contratado de Projeto I.

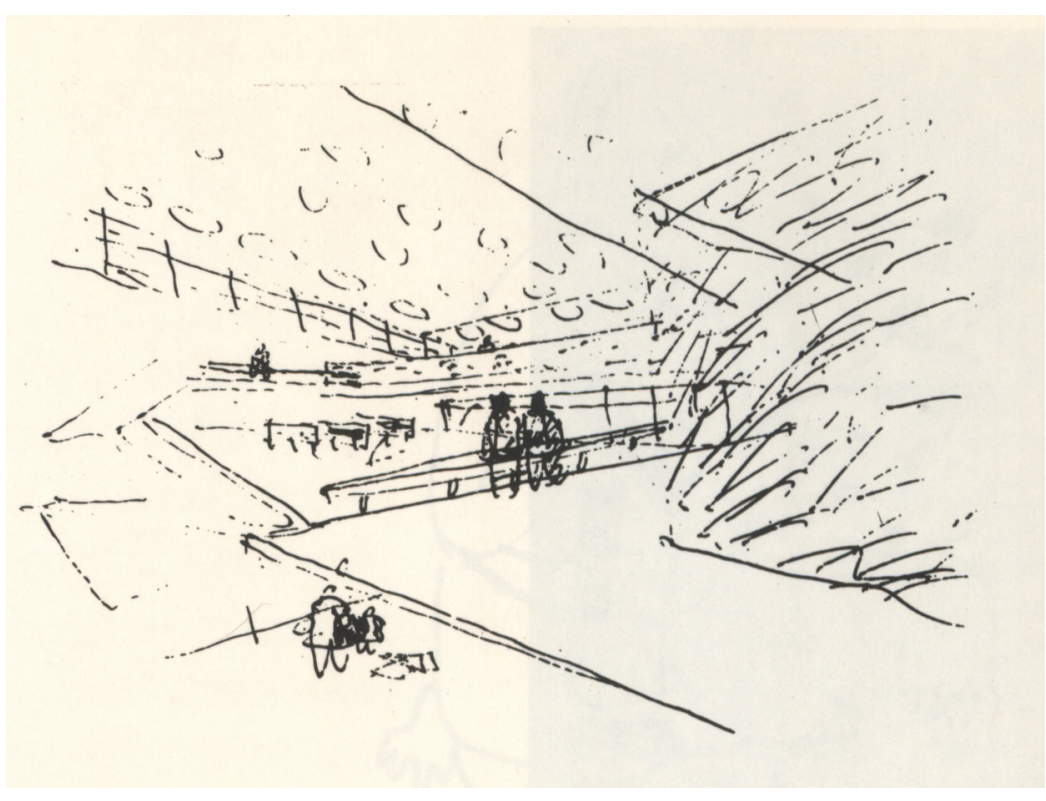

Figura I2 - Croquis do projeto do edifício da FAUUSP na Cidade Universitária 


\subsection{Atuação no IAB-SP}

No campo da realização de projetos, conforme já sinalizado por Gabriel (2003), Artigas tendeu à busca por autonomia, trabalhando em poucas ocasiões com seus colegas de profissão. Na luta pelo fortalecimento institucional da categoria, contudo, Artigas atuou em São Paulo ao lado de diversos profissionais ligados à arquitetura moderna.

Conforme procuramos demonstrar no Capítulo 01, a criação do IAB-SP foi parte decisiva de um movimento dos arquitetos atuantes em São Paulo visando à autonomia da profissão face à engenharia com vistas à conquista da hegemonia da arquitetura moderna. A partir de então, esses profissionais tenderam a afastar-se das demais instituições ligadas à Politécnica e à engenharia. No momento de criação do IAB-SP, havia uma pluralidade de grupos ligados à arquitetura interessados na autonomia do campo. Entretanto, a diversidade foi rapidamente sendo apagada, instaurando-se a hegemonia da arquitetura moderna a partir de então. Em pouco tempo, arquitetos que não fizessem trabalhos modernos tinham sua filiação ao IAB recusada (DEDECCA, 2012, p. 56), de modo que, a partir de determinado momento, desligar-se da engenharia passou a corresponder a posicionar-se como arquiteto

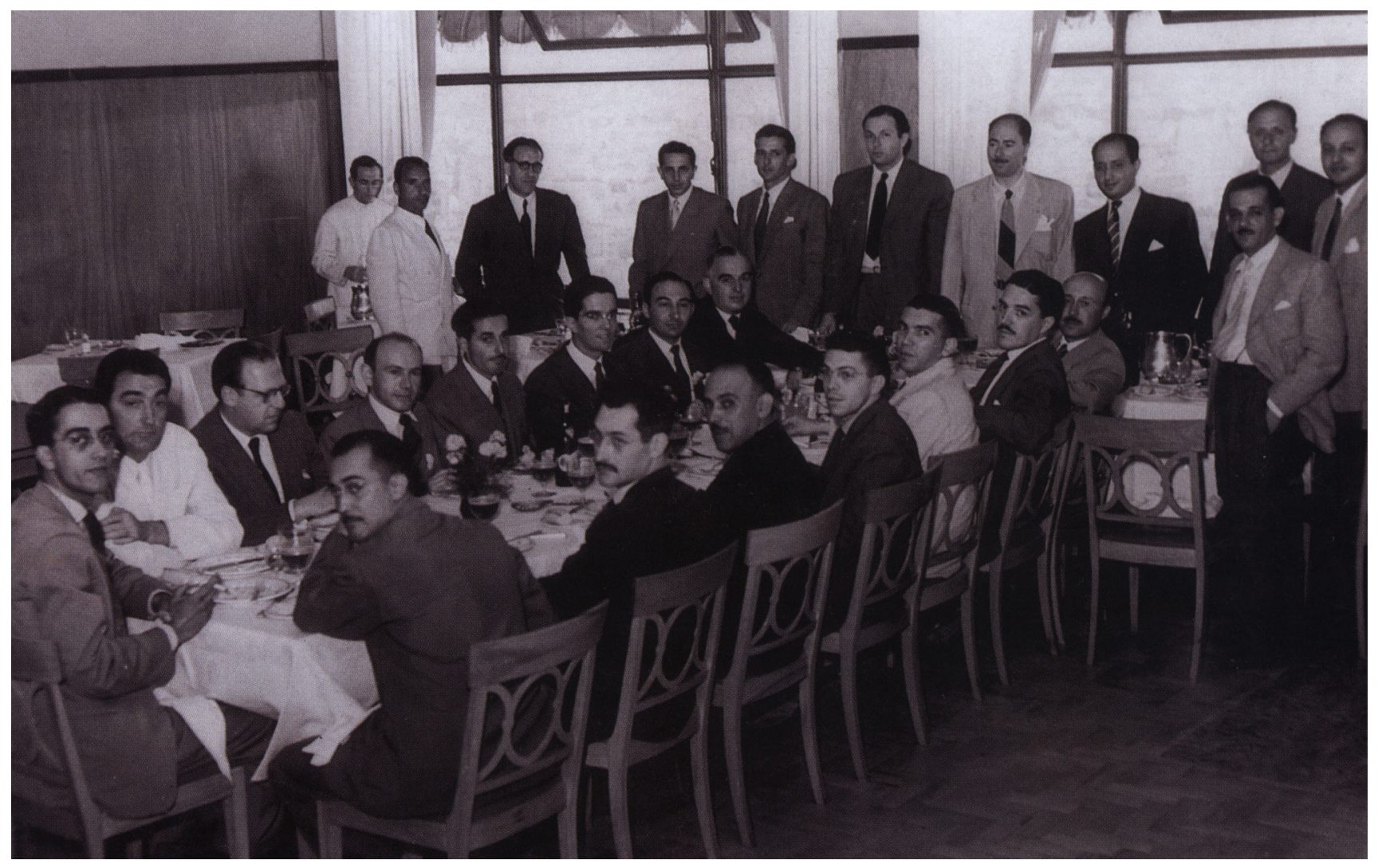

Figura I3 - Almoço no Hotel Excelsior, mobilização pela fundação da FAUUSP. 
moderno. Isso levou os arquitetos mais conservadores, a exemplo de Christiano Stockler das Neves, a procurar estabelecer uma contraposição ao IAB pela reativação do Instituto Paulista de Arquitetos, IPA, criado em 1930 e ocupado por profissionais de orientação acadêmica.

Desde que se iniciou na docência, Artigas ocupou cargos de representante da Escola Politécnica em instituições de Engenharia, seja como delegado do CREA (1941-1942), como membro de uma comissão de normas técnicas (1945), dentre outros. Todavia, dentre as instituições de arquitetura em que atuou fora da universidade, certamente foi junto ao Instituto de Arquitetos do Brasil aquela em que militou persistentemente. O arquiteto foi um dos que participaram da gestação do instituto em São Paulo. Entre 1943 e 1947, participou da primeira diretoria do IAB-SP, ocupando o cargo de $1^{\circ}$ Secretário. Nesse período, colaborou com a organização do I CBA, e da exposição de arquitetura a ele vinculada. Participou também das gestões de 1957-1958 e 1959-1961, ambas sob a direção de Ícaro de Castro Mello.

Deve-se considerar que participando ou não diretamente da diretoria do IAB-SP, Artigas manteve um contato permanente com os profissionais envolvidos naquela instituição. Em 1951, seu escritório profissional passou a ocupar o edifício-sede daquele órgão, recém-inaugurado, ao lado de outros arquitetos como Rino Levi, Paulo Mendes da Rocha, Galiano Ciampaglia, Miguel Forte, Oswaldo Correia Gonçalves, Léo Ribeiro de Morais e Fábio Penteado (IAB, 2006, s/p).

\subsubsection{Os Congressos Brasileiros de Arquitetos}

Durante a primeira gestão do IAB-SP, possivelmente a realização mais importante da instituição tenha sido organizar o I CBA, sediado no município de São Paulo entre 26 e 30 de janeiro de 1945. Os CBA, realizados desde então, mantém o comprometimento com a discussão dos interesses da categoria profissional. Foi um espaço importante de debate e consolidação de ideias no momento de constituição do campo de arquitetura autônomo em relação à engenharia e às belas artes.

O estudo da "Função Social do Arquiteto" aparecia como a primeira das finalidades do primeiro congresso (IAB, 1945, p. 09), visando solucionar problemas na cidade e no campo que dissessem respeito ao bem-estar das coletividades (Art. $1^{\circ}$, item a). Esse tema abordava, especialmente, a questão do urbanismo, tido como "problema de arquitetura", a ser tratado a partir do preceito funcionalista consagrado na Carta de Atenas. O documento também expressava a preocupação com a fixação do homem em núcleos rurais e industriais, além da importância de se melhorar o entendimento entre o arquiteto e a indústria para a "evolução arquitetônica" (IAB, 1945, p. 21-22). Portanto, expressava inquietações em torno da industrialização da construção, do planejamento urbano e do controle do êxodo rural, associado àquele. 
Além disso, o Congresso tinha por finalidade discutir assuntos de interesse imediato da profissão, tais como o ensino de arquitetura, a regulamentação profissional e o estabelecimento de normas de trabalho. Pretendia-se debater mecanismos de fortalecimento institucional, de divulgação dos trabalhos dos profissionais ligados ao IAB e de influencia sobre o governo e a opinião pública. Observam-se pontos de tangência e objetivos comuns entre os arquitetos e o urbanismo de Anhaia Mello, como os temas da conquista da opinião pública, do planejamento urbano e rural e a fixação do homem no campo ${ }^{14}$.

Dentre as teses apresentadas no congresso, a revista Acrópole divulgou as conclusões de um dos trabalhos, relativo à construção da casa popular. Naquele congresso teve também destaque a adoção do planejamento regional como o instrumento capaz de dar respostas aos problemas de organização da produção, circulação e distribuição de riquezas, planejando a localização das atividades de produção e o sistema de transportes. Com isso, pretendia-se programar a organização das coletividades, tendo em vista o zoneamento e a fixação do homem em núcleos organizados, evitando a dispersão pelo território. Finalmente, defendia-se que, visando impedir o agravamento das condições de vida nos centros populosos, dever-se-ia dar preferência à fixação do homem nos núcleos rurais e industriais ao invés de ocuparem-se as periferias dos núcleos urbanos ${ }^{15}$. A temática abordada pelos arquitetos compreendia um vocabulário muito semelhante ao empregado nas defesas do urbanismo empreendidas por Anhaia Mello.

Devemos assinalar que, como é possível observar pelas pautas incluídas no I CBA, em 1945 os arquitetos brasileiros procuravam assumir a problemática da planificação da cidade. É necessário, portanto, compreender o entendimento desses arquitetos quanto ao que seria o planejamento da cidade. Ainda que empregassem um vocabulário igual ao adotado por Anhaia Mello, o sentido atribuído a esses termos diferia. Para Anhaia Mello, as referências, ao falar de planejamento e zoneamento eram sobretudo o regional planning norte-americano. Já para os arquitetos em torno do IAB, as referências do urbanismo estavam muito mais próximas das ideias difundidas dos Congressos Internacionais de Arquitetura Moderna, especialmente o IV CIAM de 1933, quando se formulou a Carta de Atenas. Outra referência importante era o urbanismo propalado por Le Corbusier em suas obras sobre o assunto, como veremos mais detalhadamente no próximo capítulo.

O III Congresso, realizado em 1953 em Belo Horizonte, contou com um temário organizado em quatro grupos, continuando a tratar dos interesses profissionais, procurando definir as atribuições dos arquitetos e seus direitos, dentre outras questões. Constava a necessidade de regulamentação, por meio de lei, da participação do arquiteto no serviço público. Além disso, havia uma preocupação em definir as atribuições do engenheiro e do arquiteto em função da formação universitária e em tratar a questão do direito autoral do anteprojeto. Ao mesmo tempo, procurava-se definir o conceito de monumentalidade e sua interpretação para efeito de Tabela de Honorários e regulamentação para concursos, a regulamentação profissional do urbanista e a participação do arquiteto nos planos urbanísticos

14 Conferir, por exemplo "Problemas de Urbanismo: Bases para a resolução do problema technico" (1929) ou "Elementos para o planejamento municipal do território" (1957), ambos de autoria de Anhaia Mello.

15 Acrópole, São Paulo, 81-82, jan-fev. 1945, p. 271 
(nacionais e regionais) e na supervisão das equipes, a ser respaldada por lei. O urbanismo deveria ser uma das atribuições dos arquitetos. Esses profissionais especializados comporiam o quadro de urbanistas do Brasil. Esse foi um dos grandes embates entre o IAB e o Confea na discussão que se daria entre 1958 e 1959 em torno da nova regulamentação da profissão

O IV Congresso foi realizado em São Paulo entre 17 e 24 de janeiro de 1954 e estava incluído na agenda de comemorações do $4^{\circ}$ Centenário da cidade. O evento acontecia concomitantemente a outros eventos culturais, como a $2^{\text {a }}$ Bienal de São Paulo, o que atraiu também diversos arquitetos estrangeiros como Alvar Aalto e Walter Gropius, os quais palestraram durante o congresso. Anhaia Mello também compareceu, constando na relação de "personalidades presentes" no evento, ao lado de outros representantes de escolas de arquitetura brasileiras, de órgãos municipais, dentre outros. Artigas compôs a comissão organizadora do evento, ocupando o cargo de tesoureiro, ao lado do presidente Leo Ribeiro de Moraes e do secretário Oswaldo Corrêa Gonçalves. Os demais membros da comissão eram: Abelardo de Souza, Eduardo Corona, Icaro de Castro Mello, Rubens Gouveia Carneiro Viana, Carlos Brasil Lodi, Alfredo Ernesto Becker e Eduardo Kneese de Mello. Novamente a questão da separação entre as profissões de arquitetos e engenheiros civis esteve presente. Na sessão solene de instalação do congresso, Leo Ribeiro de Moraes manifestou-se afirmando que:

Nós, arquitetos, no domínio de nossa profissão, no domínio da arquitetura, temos tido sempre um concorrente muito sério que é o engenheiro civil. E isso devido, principalmente, ao pequeno número de arquitetos que ainda existe no Brasil. Evidentemente não agem eles por má fé nem por vontade própria, mas por necessidade imposta pelas circunstâncias. No 1 fl Congresso Brasileiro de Arquitetos (...) o então Presidente Paulo Camargo falou a respeito dos politécnicos, que são os engenheiros civis, que são os homens que sabem fazer de tudo, inclusive arquitetura. Daí o fato de haver ocorrido um mal para a arquitetura brasileira (...) porque, não tendo tido oportunidade, através de um curso (...) dão soluções aparentemente modernas ao problema da arquitetura. O que estamos verificando - $e$ isso os engenheiros civis devem ser os primeiros a reconhecer - é que realmente o problema da Arquitetura deve ser resolvido pelo arquiteto (...). Felizmente o arquiteto está sempre disposto a lutar, a defender o seu ponto de vista. É o que verificamos também nos demais setores da atividade (IAB, 1954, p. 20-21).

Essa manifestação gerou um incômodo entre os engenheiros presentes, de modo que foi necessário explicar-se e retratar-se durante a $1^{\text {a }}$ sessão plenária (IAB, 1954, p. 40-41). De toda forma, o seu discurso revela o empenho dos arquitetos em ganhar autonomia em relação aos engenheiros civis e, especialmente, dos politécnicos, buscando o fortalecimento da legitimidade e autoridade da categoria profissional de arquitetos. No mesmo congresso, a fala do arquiteto cubano Aquiles Capablanca acerca do tema, afirmando conhecer "perfeitamente a luta que há em todos os países por querer o engenheiro invadir o campo da nossa profissão e pretender que a lei lhe confira atribuições que são concedidas exclusivamente a nós, arquitetos" (IAB, 1954, p. 51) indica que a questão não era pertinente apenas ao Brasil, sugerindo que esse movimento de fortalecimento da categoria profissional diante do campo da engenharia ocorria simultaneamente em outras partes do mundo. 
Artigas não apresentou tese no congresso nem presidiu comissões de estudos ${ }^{16}$. Ainda assim, participou de alguns debates. A maioria de suas intervenções se referia a questões de ordem. Na quarta sessão plenária do congresso, participou da discussão sobre o ensino de arquitetura, debatendo o formato adequado a ser adotado por um grupo de trabalho visando conceber uma reforma de ensino (IAB, 1954, p. 93). A proposta era revisar os currículos do curso, focando o entrosamento das disciplinas e horários compatíveis com o problema do aluno que necessita trabalhar, bem como a relação entre os conteúdos curriculares e a realidade. Na quinta sessão plenária, debatendo as teses sobre "arquitetura e tradição" apresentadas no congresso, Artigas fez uma defesa da "cultura nacional" como critério fundamental para a preservação de edifícios. Sua intervenção se deu em um momento em que seus colegas divergiam quanto ao significado e à pertinência do termo "tradição", a partir de uma manifestação do arquiteto Angelo Murguel. Este questionava o fato de que a "tradição" remetia a uma cópia obediente das formas e dos materiais da arquitetura brasileira tradicional. A argumentação de Artigas se deu, portanto, no sentido de procurar superar a discussão de nível estético adotando o denominador da cultura nacional, que definiria o “povo brasileiro" (IAB, 1954, p. 110-111).

Com base nos documentos analisados, nota-se a centralidade da questão da diferenciação do profissional de arquitetura com relação ao de engenharia nos congressos realizados entre 1945 e 1954. Decerto, isso não ocorria sem conflito de interesses entre as duas classes, como pudemos observar. A construção desse campo autônomo de arquitetura, da maneira como foi concebido nesses congressos, passava pelo fortalecimento institucional, via estruturação do IAB, e discussão dos interesses imediatos da profissão, incluindo a criação de mecanismos para conquistar influência junto aos governos e à opinião pública, dentre outros. Entretanto, é possível identificar um conteúdo programático que se construía para embasar a reivindicação por distinção da categoria face à engenharia. Dentre esses, talvez o mais notável seja a Função Social do Arquiteto e, ainda neste âmbito, o urbanismo como uma atribuição da arquitetura. A Função Social do Arquiteto, que abriu o I CBA, foi, quase quarenta anos depois, o tema da prova didática de Artigas em seu concurso para livre-docente.

\subsubsection{A luta do $I A B$ pela regulamentação profissional}

O fortalecimento institucional da categoria de arquitetos por meio da revisão da regulamentação profissional foi pautado com insistência pelo IAB desde os anos 1940, aparecendo como tema já no I CBA, como parte dos “interesses imediatos dos arquitetos". Foram

16 Isso não está claro, pois embora ele não conste na relação de membros de nenhuma comissão, durante a sessão da $4^{\mathrm{a}}$ plenária Ariosto Mila afirma que Artigas era membro da Comissão de Ensino de Arquitetura (IAB, 1954, p. 93). 
feitas inúmeras críticas ao decreto 23.569 de 1933, primeiro regulamento da profissão em nível federal.

Durante o III CBA, em 1953, Eduardo Kneese de Mello propôs o cancelamento do artigo $8^{\circ}$ do decreto ${ }^{17}$, que, segundo ele, levava a uma situação contraditória, relativa aos "construtores licenciados", profissionais não diplomados, "leigos pertencentes a empresas em que houvesse profissional habilitado na área de arquitetura”, em suas palavras, que também podiam exercer a profissão. No mesmo congresso, Nestor de Figueiredo propôs a criação de um órgão profissional de arquitetura separado do CREA, denominado "Conselho da Ordem dos Arquitetos”. A partir de então, passou-se a estudar a questão, que voltou a ser abordada em 1954, durante o IV Congresso, incumbindo-se o próprio Nestor de Figueiredo de apresentar um novo projeto de lei. A respeito desse projeto, o arquiteto afirmou, durante o IV CBA, que:

(...) o Projeto da criação do Conselho da Ordem dos Arquitetos pretende separar definitivamente as duas funções que algumas vezes, com grave prejuízo para os arquitetos e gravíssimos prejuizos para a Arquitetura brasileira, têm sido exercidas, até agora, em muitos casos em conjunto, isto é, a do arquiteto e a do construtor empreiteiro. (IAB, 1954, p. 39).

Após o término do IV CBA, foi criada uma comissão para estudar esse projeto de lei, que finalmente foi apresentado ao sistema Confea/CREA em 1958. Na proposta de regulamentação profissional apresentada pelo IAB, dentre outras questões, reivindicava-se o urbanismo como atribuição exclusiva do arquiteto, engendrando grandes disputas. Neste ponto estava a principal divergência entre os arquitetos e Anhaia Mello, que defendia o urbanismo como "ciência multidisciplinar". O urbanismo de engenheiros politécnicos era orientado pela disposição de infraestrutura na cidade, sobretudo viária, de transporte e de drenagem $^{18}$. Anhaia Mello, ao propor um urbanismo baseado na regulamentação legal, tendo como principal instrumento o plano diretor (nacional, regional, municipal), rompia com os planos urbanísticos tradicionalmente elaborados pelos politécnicos. Ao tratar das questões de urbanismo, os arquitetos modernos atuantes em São Paulo apropriaram-se sobretudo da versão de urbanismo propalada por Anhaia Mello. Entretanto, tratou-se de uma

$17 \mathrm{O}$ artigo a que se refere Eduardo Kneese de Mello é o seguinte:

Art. $8^{\circ}$ Os indivíduos, firmas, sociedades, associações, companhias e emprêsas em geral, e suas filiais, que exerçam ou explorem, sob qualquer forma, algum dos ramos da engenharia, arquitetura ou agrimensura, ou a seu cargo tivarem alguma secção dessas profissões, só poderão executar os respectivos serviços, depois de provarem, perante os Conselhos de Engenharia e Arquitetura, que os encarregados da parte técnica são, exclusivamente, profissionais habilitados e registrados de acôrdo com êste decreto.

$\int 1^{\circ} \mathrm{A}$ substituição dos profissionais obriga a nova prova, por parte das entidades a que se refere êste artigo.

$\int 2^{\circ} \mathrm{Com}$ relação à nacionalidade dos profissionais a que êste artigo alude, será observado, em tôdas as categorias o que preceituam o art. $3^{\circ}$ e seu Parágrafo único do decreto n. 19. 482, de 12 de dezembro de 1930, e o respectivo regulamento, aprovado pelo decreto n. 20. 291, de 12 , de agôsto de 1931.

18 A exemplo dos trabalhos de Prestes Maia ou Saturnino de Brito. 
apropriação parcial. Defendiam instrumentos como o plano e o zoneamento, mas ignoravam a questão da multidisciplinaridade, uma vez que, para eles, o urbanismo concebido como atribuição exclusiva de arquitetos visava o fortalecimento da categoria, assim como sua autonomia face à engenharia.

Artigas não só participou da Comissão do IAB para a revisão da regulamentação da profissão, como se posicionou com relação a este assunto em diversas ocasiões durante o período. Observamos manifestações do arquiteto acerca daquela proposta em diversos meios, defendendo-a contra as múltiplas reações contrárias que advieram por parte de engenheiros, do CREA, da Escola Politécnica e mesmo de Anhaia Mello, a quem foi solicitado um parecer, como vimos no capítulo anterior. Um dos espaços privilegiados para a expressão dessas ideias foi junto aos estudantes da FAUUSP. Em 1956, em meio a um debate sobre ensino proposto pelo grêmio estudantil, Artigas dedicou parte substancial de sua fala a essa questão, ao tratar das dificuldades enfrentadas pelos arquitetos na prática profissional. O docente denunciou a confusão entre

(...) a atividade do técnico e do artista com o exercício da construção, que o próprio Decreto 23.569, que regulamenta a profissão do engenheiro e do arquiteto, baseia-se nessa incompreensão inicial, exigindo para construtores, técnicos e artistas capacitação idêntica (...) (ARTIGAS, 2004, p. 67).

Acusando a regulamentação profissional brasileira de sujeitar os arquitetos e engenheiros às imposições da lucratividade, Artigas rebateu que:

(...) não é por outra razão que a legislação reguladora do exercício profissional do engenheiro e do arquiteto, em países mais desenvolvidos, proíbe, terminantemente, qualquer associação do técnico e do artista a interesses comerciais decorrentes de seus projetos (idem, p. 68).

Portanto, naquele momento, o discurso de Artigas demonstrava mais empenho em fazer separar as atividades de projeto (de engenharia ou de arquitetura) das de construção. Considerando de que se tratava de uma proposta a ser encaminhada ao Confea/ CREA, o arquiteto lançou mão de uma estratégia de convencimento, procurando demonstrar que a lei não era apenas prejudicial aos arquitetos. Naquele discurso, Artigas deu muita ênfase à valorização do "trabalho intelectual do técnico e do artista", em detrimento da obrigação daqueles profissionais serem forçados a atuarem no campo da construção. Já no seu discurso de Paraninfo de 1958, a proposta de regulamentação já havia sido apresentada e a dedicação ao assunto foi ainda maior. O docente retomou a ideia que desenvolvera em 1956, afirmando que:

Para mantermos o prestígio que granjeia a arquitetura brasileira, e para o avanço que desejamos ver em processo, é indispensável que maior número de profissionais encontrem destino seguro na vida prática. Sem campo para a ação de um grande número de militantes, a obra já feita permanecerá uma reduzida expressão qualitativa. 
(...) Não nos tem faltado o apoio da intelectualidade brasileira e das diversas camadas de nosso povo. As oportunidades que o governo de nosso país promoveu, as temos aproveitado condignamente. Mas existe para nós ainda uma medida de reconhecimento que há muito esperamos: a criação da profissão de arquiteto em condições de independência.

$\mathrm{Na}$ verdade, até agora, a despeito de todos os sucessos e de todos os esforços encaminhados, continuamos a comparecer perante a sociedade como mera especialização da engenharia, subordinados à indústria da construção (ARTIGAS, 2004, p. 71).

No mesmo discurso, Artigas denunciou os problemas do Decreto n² 23.569/1933, que avaliou ter sido o resultado de um momento político, quando se legislava "com os olhos voltados para as organizações corporativistas" (idem, ibidem). O docente chegou a defender uma contraproposta feita pelo Instituto Paulista de Arquitetos nos anos 1930, de arquitetos de posição conservadora, como Christiano Stockler das Neves, que, segundo ele, apresentou um projeto de regulamentação baseado em "uma maneira de pensar muito mais democrática”. Artigas ressaltou ainda que sua reivindicação de revisão da regulamentação profissional não visava unicamente interesses da categoria, mas também a defesa do patrimônio cultural brasileiro contra o "ataque" de empresas estrangeiras que, naquela situação, podiam "urbanizar" o Brasil a partir de valores culturais estrangeiros e ameaçando a cultura nacional. Ao fim do discurso, Artigas reiterou que:

Quando reivindicamos para os arquitetos um organismo proprio que oriente o destino cultural da arquitetura, encontramos no seio da engenharia nacional algumas expressões de descontentamento. Entretanto, os arquitetos não disputam o terreno de ação da engenharia. A arquitetura é um caminho à parte, original e único. Ela contém a visão técnica em convivência com a visão artística (...) a proposição inicial na pesquisa formal tem conteúdo humano. O humano, na arquitetura, condiciona o técnico. A visão do engenheiro é essencialmente técnica (ARTIGAS, 2004, p. 73).

Argumentando em defesa da cultura nacional, tema por ele recorrentemente levantado, e procurando justificar a necessidade social da separação dos órgãos profissionais de arquitetura e de engenharia, Artigas não falava, decerto, unicamente a seus alunos. O docente empreendia uma campanha de convencimento acerca da premência de revisão da regulamentação profissional em favor de maior autonomia para a arquitetura e para os arquitetos. Durante uma aula inaugural aos estudantes da Faculdade de Arquitetura e Urbanismo da Universidade Federal do Rio Grande do Sul em 1959, Artigas trouxe novamente à tona essa discussão. A esses alunos, denunciou o problema de se tratar a arquitetura como especialização da engenharia, refletindo-se tanto no campo do ensino como na prática profissional. A fim de justificar a separação dos campos, Artigas distinguiu as origens da arquitetura e da engenharia, afirmando que no Brasil, a origem de uma foi no ensino de Belas Artes, desde Grandjean de Montigny e a outra teve origem militar. Para Artigas, os dois campos "se confundiram não faz muito, talvez devido à insignificân- 
cia dos problemas propostos à engenharia, num país de economia agrária e rudimentar" (ARTIGAS, 2004, p. 76).

O responsável por tal situação era, novamente, o Decreto n²3.569/1933, em que se confundiam as duas profissões, apesar de uma ser técnica e uma de conteúdo artístico-cultural $^{19}$. Artigas insistiu ainda no fato de que o decreto beneficiava muito mais a indústria da construção e as organizações imobiliárias do que os profissionais e as contribuições que esses poderiam trazer. O principal papel que cabia, segundo ele, aos engenheiros era o de lutar pela industrialização nacional.Também o engenheiro não poderia mais reproduzir "o antigo politécnico, cujo papel para as camadas dirigentes era de caráter representativo" (ARTIGAS, 2004, p. 78). Artigas conclamava assim os engenheiros a solidarizarem-se com a causa, afirmando mesmo que:

Quando protestamos contra desvios da tradição nacional, como o que, segundo disse, representa a legislação que queremos substituída, não o fazemos reivindicando em proveito próprio, como maldosamente já se disse. Mas considerando tão-somente a atenção que devemos aos mais puros desejos do povo e da pátria (ARTIGAS, 2004, p. 80).

A depender do decreto, a expressão arquitetônica nacional teria desaparecido. O que a salvou, segundo o docente, teria sido o movimento moderno, "na medida em que ele exprimiu o desejo de progresso contido na nacionalidade, o desejo de romper com as amarras do nosso passado de país semifeudal e agrícola” (ARTIGAS, 2004, p. 78).

\section{A "Função Social da Arquitetura" e a ideia de plano dela decorrente}

Aracy Amaral (1983), assinalando a inexistência de uma crítica sistemática da arquitetura produzida no Brasil, procurou levantar os principais argumentos apresentados pelos arquitetos brasileiros a partir dos anos 1940 para identificar como foi pensada a função social em arquitetura. Em sua pesquisa, a autora identificou no posicionamento de arquitetos que se manifestaram sobre essa questão uma busca por um duplo reconhecimento do profissional, como artista plástico e ao mesmo tempo como próximo da engenharia e da

19 Neste ponto, Artigas passou por cima da arquitetura como "arte-ciência" para valorizar o seu caráter artístico-cultural, a fim de distanciá-la ainda mais da engenharia. É curioso como entre 1956 e 1959 houve uma progressão no discurso de Artigas, partindo de uma situação em que se procurava angariar o apoio dos engenheiros contra o Decreto $n^{\circ} 23.569$ e finalmente distinguir completamente as duas áreas, abrindo mesmo mão da ideia da arquitetura como disciplina técnica, a fim de justificar a proposta do IAB. 
cientificidade. Esse modo de entender a profissão, que talvez também possa ser interpretado como uma expressão da dupla origem da formação do arquiteto até meados do século passado, em escolas de Belas Artes ou Politécnicas, pode ser reconhecido no discurso de muitos profissionais entre as décadas de 1940 e $1950^{20}$.

Artigas remeteu a essa dupla definição em diversas ocasiões. Em um discurso aos formandos da FAUUSP de 1955, para defender a renovação da arquitetura brasileira e a superação do ecletismo, o docente afirmou que "a grande maioria de nossa intelectualidade logo compreendeu que os projetos dos arquitetos brasileiros revelam sempre o desejo ardente de encontrar uma solução técnica e artística adequada aos problemas de construção no Brasil" (ARTIGAS, 2004, p. 60). Nesse sentido, ele afirmava que a renovação no campo da arquitetura não podia prescindir de inovações técnicas realizadas no campo da engenharia, a exemplo do desenvolvimento do concreto armado (idem, p. 61).

Em outro discurso, Artigas retomou essa questão, definindo a arquitetura como sendo: "antes de tudo expressão cultural de um povo, que se serve do avanço técnico e da produção industrial, sobre os quais se exerce também sua influência criadora” (idem, p.71). A definição da arquitetura como uma área tão próxima da arte quanto da engenharia não impediu que muito empenho fosse colocado na defesa da autonomia de uma profissão em relação à outra, como se observou na proposta de regulamentação da profissão do IAB de 1958. Dessa forma, entendemos que tal definição para a arquitetura visava equiparar os estatutos das duas profissões do ponto de vista da cientificidade, de modo a atribuir à arquitetura uma legitimidade tal que justificasse sua autonomia face à engenharia.

Em 1984, Artigas retomou a relação entre os campo de arquitetura e de engenharia, no sentido da defesa da autonomia. Para tanto, criticou a divisão de atribuições entre saber artístico e técnico:

Uma (...) questão (...) que deveríamos debater neste momento é: Quando houve a separação entre a engenharia e a arquitetura e por que se fez isso? Qual é o sentido dessa separação? (...) o arquiteto moderno começa a ver na verdade técnica, na sinceridade de relação entre engenharia, como colaboradora do projeto, e o material uma crítica sobre a superficialidade com que o ecletismo arquitetônico tratava suas ideias a serem realizadas. Nessa ocasião, o trabalho do engenheiro separou-se do arquiteto sem que isso fosse estranho. A contribuição dos engenheiros para a moralidade da arquitetura é tão grande que Corbusier, particularmente, chama a atenção para esse fato, de maneira muito clara, mostrando a necessidade de relação entre a engenharia, como colaboradora do projeto, e o arquiteto, como o homem que propõe a forma artística. (...) é uma passagem da história ainda não resolvida: como essa integração pode ser feita. Isso se faz com uma palavra meio sublime, interdisciplinaridade, que já mereceu críticas incriveis. Dá margem a isso que se chama trabalho de equipe

20 Esses discursos são identificados nos CBA realizados nesse período. Apenas como exemplo, em 1954, o arquiteto Ângelo Murguel definiu a arquitetura como "arte-ciência de planejar e construir tudo o que é necessário à atividade, à vida do homem, da maneira mais fácil, prática, conveniente, estática e bela, em concordância com as ideias, hábito e habitat" (IAB, 1954, p. 110). 
e que, em certa ocasião, Walter Gropius criticou (...) dizendo: "Um camelo é um cavalo projetado em equipe" (ARTIGAS, 2004, p. 204-5) ${ }^{21}$.

Amaral (1983, p. 310) ressaltou, contudo, que a forma de inserção do arquiteto como artista e cientista redundou, no Brasil, em um esteticismo, o que se deveu à recusa em aprofundar-se a autocrítica dos arquitetos atuantes no país. Nos anos 1950, três foram os argumentos adotados por esses profissionais para justificar os fracassos dos projetos da arquitetura moderna no Brasil. Em primeiro lugar, culpou-se o baixo nível de desenvolvimento tecnológico nacional. Além disso, apontou-se que o problema era a arquitetura ter sempre estado a serviço das classes dominantes. Finalmente, uma justificativa apresentada primeiramente por Oscar Niemeyer em 1946 delegou a frustração com a arquitetura moderna brasileira à falta de base social efetiva ou de planos mais amplos que deveriam respaldar essa arquitetura.

Com relação à crítica da arquitetura a serviço das classes dominantes, Amaral já explicitou algumas das contradições e insuficiências deste argumento. Por um lado, considerando que os anos 1950 eram marcados pela luta pelo fortalecimento da categoria profissional, em que os arquitetos procuravam consolidar-se como os "chefes" coordenadores de equipes científicas responsáveis por propor soluções para o habitat e para a cidade, isso significava justamente que tais arquitetos procuravam transformar-se em classe dominante. Tratava-se, portanto, de uma reivindicação de classe profissional, muito mais do que de uma preocupação de ordem coletiva (AMARAL, 1983, p. 310). Além do mais, a autora chamou a atenção para a reiteração de que o arquiteto detinha o poder de alterar a estrutura social de uma nação através de seu fazer arquitetônico. Essa ideia levava a ignorar o fato de que o arquiteto, ao contrário do que se propunha, existia justamente a serviço do poder. A autora observou, ainda, que embora a crítica de fundo fosse o trabalho a serviço das classes dominantes, a arquitetura moderna brasileira, entre as décadas de 1930 e 1940, somente pode existir em função de seu patrocínio pelo governo ditatorial de Vargas, o que também levou à elaboração de uma arquitetura monumental, imponente e cara, sobretudo no Rio de Janeiro, capital federal. Em São Paulo, em contrapartida, os arquitetos não tiveram naquele período grandes oportunidades de trabalhar para o Estado, de modo que somente poderiam sobreviver na iniciativa privada (AMARAL, 1983, p. 305).

Artigas foi um dos arquitetos que insistiram na leitura de que os limites da arquitetura moderna no Brasil residiam no fato de esta colocar-se a serviço das "classes dominantes", ideia que coexistia com a crença de que a arquitetura podia interferir na ordem social.

Em 1955, afirmou aos formandos da FAUUSP que o domínio da arte e da técnica só poderia resultar em melhores condições de vida para a sociedade brasileira a partir do momento em que estivessem instaladas as condições sociais e econômicas em uma nação "plenamente desenvolvida e de um povo próspero e feliz" (ARTIGAS, 2004, p. 63). Nos artigos publicados na revista Fundamentos entre 1951 e $1952^{22}$, essa ideia já se encontrava

21 Observe-se que Artigas posicionou-se contrariamente a algo que era fundamental para seu mestre na Politécnica - a multidisciplinaridade.

22 Nos referimos aos conhecidos textos "Le Corbusier e o imperialismo" (1951), "A bienal é contra os artistas brasileiros" (1951) e "Os caminhos da arquitetura moderna" (1952). 
formulada. Esses textos, produzidos no âmbito da militância do PCB, reiteravam a arquitetura como arma de opressão a serviço dos interesses da camada dominante. Ele propunha que a boa arquitetura só poderia ser alcançada quando se estabelecesse uma relação entre arquitetos e povo, quando arquitetura passasse a ser debatida "nas fábricas e nas fazendas" (ARTIGAS, 2004, p. 49). Essa seria a forma de libertar-se dos vínculos dos arquitetos com o poder e com as classes dominantes.

Em "Os caminhos da arquitetura moderna", Artigas concluiu que enquanto as condições sociais, políticas e econômicas não permitissem uma plena atuação do arquiteto, restava àquele "uma atitude crítica face à realidade" (idem, p. 50). Sobre essa questão, Amaral questionou até que ponto isso seria possível, uma vez que a arquitetura, sendo um fazer utilitário, dificilmente poderia prescindir do financiamento dos meios governamentais. Em uma entrevista de 1980, Aracy Amaral retomou esta questão com Artigas, procurando saber sua posição, quase trinta anos depois, sobre aquela ideia de "se fazer a revolução ou fazer a arquitetura que existe por aí mais ou menos". O arquiteto respondeu que a sua saída, em seu percurso, foi a de assumir uma posição crítica, mas sem parar de fazer arquitetura. Em sua visão, com essa trajetória e sob essa perspectiva, contribuiu para a formação de uma arquitetura paulista, distinta da carioca, especialmente no que se refere à relação entre a estrutura e a casa (ARTIGAS, 2004, p. 164).

Discordando da ideia de construção de uma "escola" de arquitetura, mas buscando compreender como a postura de Artigas nos anos 1950 expressou esse conflito entre as convicções políticas e a atuação profissional, Medrano e Recamán (2014, p. 82-83) concluíram que sua própria arquitetura constituía um comentário crítico acerca da realidade, nem propondo uma alternativa nem se ajustando a ela. Para os autores, a arquitetura de Artigas tendeu ao isolamento com relação ao seu contexto de inserção, com uma correspondente hipertrofia do espaço social familiar, distanciando-se, assim da sociedade. Na obra de Artigas e na linguagem arquitetônica nela inspirada que a sucedeu, o campo de arquitetura autonomizou-se do urbanismo, o que levou os autores a supor que "talvez a falta de participação dos arquitetos nas transformações das cidades brasileiras advenha mesmo da reiterada reivindicação de autonomia, no desentendimento histórico local da relação entre arquitetura e sociedade" (MEDRANO \& RECAMÁN, 2014, p. 129).

Em 1984, Artigas voltou a tecer considerações acerca do artigo de 1952, reafirmando as posições então adotadas:

Mantenho a conviç̧ão de que só profundas mudanças sociais na estrutura política em que vivemos poderão fazer com que nossa arquitetura encontre o equilibrio certo entre forma e conteúdo, entre beleza e finalidade (ARTIGAS, 2004, p. 195).

Entretanto, Amaral considerou que o posicionamento de Artigas, tanto o recém-formado quanto o "veterano idealista", semelhante ao de intelectuais e universitários inquietos do País em geral,

(...) prosseguiu se comportando (...) com uma postura dupla, aprendendo amargamente a separar a diretriz segundo a qual o país poderia solucionar seus problemas, e a realidade cotidiana a partir da qual todos vivemos 
e buscamos sobreviver. Realidade que não visa, em absoluto, a solução dos problemas inúmeras vezes denunciados, mas manter no poder as classes privilegiadas que nele se sucedem, distante das necessidades da maioria (AMARAL, 1983, p. 305).

O arquiteto "veterano" ainda mantinha a crença de que a problemática social deveria poder contar com a arquitetura "como um instrumento capaz de fazer as mudanças necessárias para nosso país inteiro” (ARTIGAS, 2004, p. 187), ignorando que a profissão do arquiteto inseria-se na ordem social instituída e não a modificava. Devemos assinalar que a ideia de que o reordenamento do espaço seria capaz de transformar as relações sociais não era unicamente de Artigas, mas foi um equívoco dos arquitetos ligados ao movimento moderno, desde sua origem europeia (ARANTES, 2000, p. 27).

Durante sua prova didática para o concurso docente, rememorando o I CBA, Artigas vinculou a problemática da "função social do arquiteto" enfrentada então pela categoria aos seguintes aspectos: a identificação do papel do arquiteto nas modificações para um novo Brasil que se desejava projetar; a ampliação do número de arquitetos com diploma para fazer face à disputa desigual com o então existente "construtor licenciado" e, assim fazendo, erigir as novas bases para cumprir as tarefas sociais que a categoria passava a reclamar; e a industrialização da construção visando ampliar a produção e democratizar o acesso à casa popular (ARTIGAS, 2004, p. 190). Artigas ponderou que a partir do advento da arquitetura moderna, sobretudo com as contribuições alemãs e de Le Corbusier, a casa popular tornou-se o maior monumento do século XX (ARTIGAS, 2004, p. 188). Na sua visão, foi a partir da discussão sobre a casa que as considerações dos arquitetos se ampliaram para o habitat humano:

Mas a verdade é que um dos fatores que surgiram imediatamente a partir da consideração da casa foi alargar esses conceitos para o habitat humano. O arquiteto passou então a pensar em torno de como deveria ser a cidade - quer dizer, o conjunto das casas ligadas entre si - e começou a formular as modificações necessárias na cidade existente. Qual a cidade ideal que poderia representar o diálogo entre os diversos edifícios e casas entre si e o diálogo da beleza formal enquanto representante do momento histórico, dos edifícios necessários para implementar ou complementar a casa, que, afinal de contas, como uma vez eu disse, não termina na soleira da porta? (ARTIGAS, 2004, p. 189).

O arquiteto definiu arquitetura como uma "arte com finalidade", finalidade que corresponderia à necessidade social de a arquitetura representar alguma coisa no campo da sociedade (ARTIGAS, 2004, p. 187). Para discutir o tema, Artigas remeteu à arquitetura moderna, partindo da premissa de que a função social tinha nela sua origem, que, por sua vez, segundo o docente, surgira das esperanças de transformação social do mundo advindas da Revolução Russa de 1917. Assim, desde sua origem até aquele momento, os arquitetos que haviam se mantido comprometidos com a responsabilidade social de seu trabalho eram ligados ao racionalismo arquitetônico. Portanto, para Artigas, a função social em arquitetura estava intrinsecamente relacionada com a perspectiva revolucionária. Dessa forma, o arquiteto também procurou situar as resistências produzidas contra a arquitetura moderna desde 
sua origem, provenientes das "camadas dominantes" (idem, ibidem). Assinalamos, todavia que embora a revolução russa possa ser considerada uma componente do contexto social mundial em que surgiu a arquitetura moderna, esta não explica nem sintetiza a formação do movimento. Deve-se ter em conta, por exemplo, o caso da Alemanha, em que a motivação que impulsionou essa arquitetura surgiu do interesse de se produzir bens de consumo em massa de qualidade, por meio da industrialização, como demonstra a experiência da Deutscher Werkbund, no início do século XX. Tratava-se, portanto, não de uma perspectiva revolucionária comunista, mas de uma democracia liberal e reformista.

Como afirmamos acima, outra das justificativas para o fracasso da arquitetura moderna no cumprimento de sua função social no Brasil era inexistência de um plano que orientasse sua realização. Essa ideia apareceu em um artigo de Oscar Niemeyer publicado na revista Joaquim, em 1946, intitulado "O que falta em nossa arquitetura". Nele, o arquiteto avaliou que a limitação da atuação profissional, restrita a projetos de edifícios para a classe dominante se devia à inexistência de um plano de maior abrangência que orientasse suas possibilidades de ação. O posicionamento de Niemeyer sinalizava para um instrumento que seria retomado de maneira reiterada por arquitetos como a principal forma de garantir realização da função social da arquitetura: o plano.

Gabriel (2003) defendeu que a construção da noção de função social pelos arquitetos nos anos 1940 foi mediada pela questão do plano. Logo na abertura do I CBA, Leo Ribeiro de Morais enfatizou que "o arquiteto é essencialmente o homem do plano" (apud GABRIEL, 2003, p. 86). As teses apresentadas no evento faziam referência explícita a pontos doutrinários dos CIAM, às experiências do urbanismo na Inglaterra na constituição de núcleos urbanos e unidades de vizinhança e instituição do zoneamento (idem, ibidem). Aquele congresso aprovou recomendações para o ensino de arquitetura no sentido de redefinir o projeto de arquitetura e o seu conceito ampliado, que era o plano (idem, ibidem). O plano dessa forma concebido correspondia ao desenho da cidade a ser seguido para localizar a edificação das obras de edifícios públicos. Nas palavras de Arantes, tratava-se da "ideologia projetista antecipatória e totalizadora que no final das contas acaba reproduzindo a vontade de poder " (ARANTES, 2000, p. 113).

No I CBA, o bloco temático "função social do arquiteto" pretendia mudar o conceito do arquiteto como profissional técnico subalterno/convocado apenas para obras monumentais. Devia-se partir do plano, como o remédio necessário aos males que afligiam as cidades brasileiras, e deveria atualizar-se permanentemente com as últimas conquistas da técnica e da ciência. Dessa froma, insistia-se na importância do desenvolvimento da indústira e no entendimento entre arquitetos e indústria para a evolução da arquitetura, na centralidade da casa popular (que conforme propunham, devia ser alugada e não adquirida) e na inserção dos problemas de urbanismo no âmbito de toda a estrutura geoeconômica do país.

O Plano, como promessa de felicidade a realizar-se, da qual a indústria, a técnica e a ciência eram fiadoras, pode absorver as projeções utópicas de dissolução da divisão social do trabalho, algo que se tornou a promessa subliminar 
do plano ou projeto como síntese das artes, como ponto de confluência de seus todo-poderosos fiadores (GABRIEL, 2003, p. 87-88).

Recomendavam-se programas de análise regional do território e o planejamento geral do país do ponto de vista econômico, além do planejamento da eletrificação nacional e a elaboração de um zoneamento industrial nacional. Defendia-se que cada cidade fosse dotada de um plano diretor que previsse limites de crescimento, subdivisões em núcleos com vida própria e densidade populacional adequada ${ }^{23}$. Vê-se, portanto, a absorção do discurso de Anhaia Mello para o urbanismo, voltado para a contenção do crescimento da cidade através do planejamento regional.

O plano, como uma ideia ampliada de projeto, construída em intima relação com a função social do arquiteto, era a ideia que permitia aos arquitetos pretender-se interlocutores do poder público, apoiados em uma plataforma que compreendia, dentre outras questões, que a propriedade privada imobiliária e fundiária eram entrave ao urbanismo (GABRIEL, 2003, p. 87-88).

A proposição de que a arquitetura moderna só poderia efetivamente se realizar com o fim da propriedade privada, ou com base na terra pública, parece ser uma resposta mal formulada dos arquitetos para a questão da "arquitetura a serviço das classes dominantes", de que tratamos acima. Podemos dizer que o fim da propriedade privada era parte da transformação das condições sociais, políticas e econômicas aguardada por Artigas e para que a arquitetura pudesse cumprir a sua função social. Ao mesmo tempo, Medrano e Recamán chamaram a atenção para o fato de que Artigas se queixava da pequena área de um terreno para o qual projetava uma residência, que, todavia, contava com generosos $500 \mathrm{~m}^{2}$ (MEDRANO \& RECAMÁN, 2014, p. 88), o que revela a insuficiência daquele argumento. O plano como ideia ampliada de projeto pautou em boa medida o discurso de Artigas acerca da Função Social do Arquiteto, fazendo-o também desejar o Estado como Cliente (GABRIEL, 2003, p. 88). A partir da análise de duas experiências de urbanismo realizadas por Artigas nos anos 1950, procuraremos situar, no próximo capítulo, como essa noção foi apropriada pelo arquiteto e contrapô-la à visão de Anhaia Mello acerca do que fosse para o plano. Com isso, procuramos mostrar que uma importante "interface" entre arquitetura e urbanismo, a partir das visões do fundadores da FAUUSP, não tinha uma perfeita correspondência de sentido.

23 Os conteúdos relativos ao I Congresso disponíveis para consulta estão nas edições de Acrópole de jan-fev/1945, 269-74 e março de 1945, p. 300. Há também uma reconstituição feita por Dalva Thomaz (1997). 


\title{
CAPÍTULO 4
}

\author{
A FAUUSP e 0 "plano" \\ como a interface entre \\ arquitetura e urbanismo
}




\title{
1.Mudanças no ensino de projeto e planejamento da FAUUSP
}

\author{
1.1. Composição de Arquitetura
}

Conforme mencionamos no Capítulo 01, até 1962 as aulas práticas de arquitetura da FAUUSP eram ministradas em quatro cadeiras de "composição de arquitetura" para os cinco ano de curso. Através da análise dos programas dessas disciplinas podemos observar uma determinada maneira de articular a arquitetura e o urbanismo, mediada pela ideia de plano.

As cadeiras dividam-se entre "Pequenas Composições" nos primeiros anos e "Grandes Composições" ao final do curso, pressupondo uma progressão da complexidade dos programas arquitetônicos a serem desenvolvidos. Contudo, observamos nos programas das disciplinas a que tivemos acesso que essa lógica não correspondia necessariamente à realidade das aulas. Conforme o fim da década de 1950 se aproximava essa diferença foi completamente diluída na dinâmica das disciplinas.

\subsubsection{Cadeira $n^{\circ}$ 16. Composição de Arquitetura. Peque- nas Composições - Partes I e II ( $1^{\circ}$ e $2^{\circ}$ anos).}

A cadeira tinha dois anos de duração e trabalhava o tema da habitação. Pudemos identificar que para os alunos de primeiro ano, os docentes foram: Artigas e Abelardo de Souza (1948), Zenon Lotufo (1949-1957) e Hélio de Queiroz Duarte (1958-1962). Além deles, há indícios de que Ícaro de Castro Mello e Oswaldo Corrêa Gonçalves lecionaram nessa cadeira no início dos anos 1950. No segundo ano, os professores responsáveis foram: Artigas e Abelardo de Souza (1949-1953), Hélio Duarte e Plínio Croce (1955), sendo desconhecidos os docentes responsáveis pela cadeira entre 1956 e 1962.

As aulas de Zenon Lotufo ${ }^{1}$ iniciavam-se com o aprendizado dos detalhes construtivos, avançando para a implantação do edifício no lote. A complexidade dos exercícios progredia de pequenas residências até a relação entre pequenos edifícios, resolvendo aspectos de insolação. Dentre os tópicos abordados no curso, estavam: materiais de construção; equipamento da habitação; o homem como modulador do espaço; organização dos espaços

1 Uma vez que os programas das disciplinas estão disponíveis apenas a partir de 1953, não pudemos analisar a disciplina sob responsabilidade de Artigas e Abelardo de Souza. 
internos e externos da habitação análise do local - situação; orientação; vizinhanças; interpretação de levantamento; discussão de programas mínimos de habitação e organização de projetos; detalhes construtivos; e implantação e de aproveitamento de lotes urbanos. Da forma como o curso se estruturava, havia uma progressão da complexidade de programa e escala, partindo-se dos detalhes para os ambientes do edifício e o conjunto de edifícios, metodologia análoga à empregada por Anhaia Mello no curso da Escola Politécnica. A relação entre arquitetura e cidade era abordada a partir da noção do aproveitamento do lote e dos aspectos de insolação. Ou seja, do ponto de vista da organização do curso da FAUUSP, no primeiro momento, manteve-se a lógica do ensino pautada na arquitetura como composição e a progressão da complexidade do escopo do trabalho ao mesmo tempo que aumentava a escala do objeto de estudo. Isso vai de encontro à tese defendida por Colquhoun de que não houve, na arquitetura moderna, um substituto para o método da composição, mas, na realidade, esse teve sua aplicação mantida sob a égide da função (COLQUHOUN, 2004, p. 50).

Por outro lado, a ênfase nos materiais construtivos (elemento que era a base da disciplina em todos os programas analisados para o período), o programa mínimo de habitação (também presente em todos os programas de disciplinas de composição da FAUUSP), a escala do homem como modulador do espaço e a nova organização dos ambientes na habitação contemporânea eram assuntos novos, trazidos dos debates da Arquitetura Moderna que se desenvolviam desde a década anterior em São Paulo, mas que vinham sendo formulados desde os anos 1920 na Europa, divulgados pelos CIAMs e pelos arquitetos que lideraram o movimento naquele continente. Ubyrajara Gonsalves Glioli, aluno de Zenon Lotufo em 1952, falou sobre sua postura em sala de aula, revelando as preocupações do docente com a funcionalidade da arquitetura moderna:

O Zenon logo na primeira aula de projeto dele, ele chegou na lousa, e falou nada. Foi lá e desenhou uma cozinha como era antigamente, com fogão de lenha, a pia (...) e depois ao lado desenhou uma cozinha moderna, arquitetura moderna: você entra, pega a comida na geladeira, dali sai coloca na pia, no fogão e serve. Aí demonstrou quantos quilômetros a mais ia andar uma empregada se fosse na cozinha antiga. E na moderna (...) aquilo me impressionou muito. Eu virei um funcionalista em função dessa aula (apud SODRÉ, 2009, p.144).

O programa proposto por Hélio Duarte levantava novas questões. A abertura do curso se dava com uma discussão conceitual sobre arquitetura. Além disso, os programas desse docente explicitavam uma metodologia de projeto que não se identificou em outros dos professores analisados, a partir em esquemas funcionais, organogramas e ideogramas. Outro aspecto interessante, que também foi explicitado no escopo de outras disciplinas, especialmente na Cadeira $n^{\circ} 17$ a cargo de Abelardo de Souza, é o entendimento da arquitetura como obra construída. Na disciplina ministrada por Hélio Duarte, pelo menos um dos temas trabalhados pelos alunos seria construído em local previamente definido. O autor do projeto seria responsável pela direção dos trabalhos e toda a turma participaria na execução das obras.

Em 1962, após uma reformulação do Departamento de Composição que prenunciava a reforma curricular que seria levada a cabo ao longo daquele ano, o programa sofreu 
algumas alterações. O curso era introduzido com "Prolegômenos sobre Arquitetura" e o "Conceito de Espaço em Arquitetura", o que indica uma tentativa de distanciamento em relação à "composição arquitetônica". No primeiro ano, partia-se de uma análise da organização do espaço interno do plano "bidimensional", seguida de um estudo "tridimensional" que previa trabalhos de oficina. No segundo ano, eram abordados três temas principais: "Teoria Geral da Habitação", "O Sítio e a Habitação" e "O Problema Social da Habitação". As mudanças na organização do programa da disciplina indicam que, naquele processo, dava-se a sedimentação de questões que permeariam a formação escolar em um momento mais consolidado de sua grade curricular. Dentre elas, o papel social do arquiteto, tema que ganhava espaço nos debates arquitetônicos em São Paulo desde a década de 1940, a tecnologia dos materiais de construção e sua relação com a arquitetura, a arquitetura como obra construída e a Arquitetura Moderna como o paradigma a ser seguido, abandonando-se, de uma vez por toda, o debate sobre os estilos e a noção de arquitetura como composição. Isso é mais explícito na análise das transformações ocorridas na Cadeira voltada para o terceiro ano do curso, que veremos a seguir.

\subsubsection{Cadeira $n^{\circ}$ 17. Composição de Arquitetura. Peque- nas Composições - Parte II2 ( $3^{\circ}$ ano).}

Conforme pudemos identificar, os docentes responsáveis por essa cadeira, voltada para o terceiro ano, foram: Hélio de Queiroz Duarte e Ernest Robert de Carvalho Mange (1950-1953), Ícaro de Castro Mello e/ou Plínio Croce (1954), e, finalmente, Abelardo de Souza e Jon A. V. Maitrejean (1955-1962).

Havia pouca diferença entre o programa desta cadeira e o da cadeira $n^{\circ} 16$, trabalhando-se também, até 1959, o tema da habitação. De 1956 em diante, passou a ser explicitado, na justificativa do programa, que "o ensino da cadeira deverá ser orientado tendo como princípio que a arquitetura é obra feita e que o projeto é o veículo para a concretização dessa obra"3. Dava-se ênfase ao conhecimento dos diversos materiais e seu emprego racional, assim como à "pesquisa social" como instrumento de projeto. O curso era inteiramente prático, sendo retomados aspectos teóricos apresentados na Cadeira $n^{\circ} 16$ quando considerado

2 Embora no programa da disciplina a cadeira $n^{\circ} 17$ conste como "Pequenas Composições", nos demais documentos da FAUUSP que fazem referência à cadeira ela é chamada de "Grandes Composições" ( $3^{\circ}$ ano).

3 Possivelmente, tratava-se de uma contribuição de Abelardo de Souza, responsável pela cadeira desde 1955. 
oportuno. Tais conteúdos a serem eventualmente abordados contribuíram para a compreensão da visão desses arquitetos sobre o campo profissional.

Dentre eles, destacamos a discussão acerca de "o Estilo e os estilos" que incluía o debate sobre o "movimento contemporâneo". Isso indicava a realização de um esforço para introduzir a discussão sobre arquitetura moderna, ainda que naquele momento ela se inserisse no âmbito dos "estilos", ainda não superados.

Outras discussões evidenciavam esse esforço. Por exemplo, o "fato arquitetônico" era apresentado como a síntese estética da função e da estrutura econômica e os "problemas estéticos" estavam ligados tanto aos aspectos sociológicos quanto psicológicos, lidando com o trinômio "Arte - Indústria - Máquina" e com a relação Arte-Sociedade.

O aspecto "social" ou "sociológico" da arquitetura também tinha um peso considerável, discutindo-se a interação entre grupos sociais e os métodos de pesquisa social. Uma parte do curso era dedicada aos "planos e processos sociais", que incluía, além de uma apresentação do "plano gerador" e suas características, a flexibilidade e o uso múltiplo do espaço, a integração vertical e horizontal e os esquemas funcionais.

O "problema da habitação" inseria-se no âmbito do habitat e do urbanismo, lidando com questões tais como o cortiço, as áreas congeladas, o zoneamento e processos ecológicos, circulação e congestionamento; edifício e cidade; metropolização. Curiosamente, o conceito de arquitetura era definido em termos de "expressão", "correlação", "integração" e "ordem orgânica”, o que remete, por um lado, à definição de Anhaia Mello para o urbanismo, como "arte social da integração e correlação" (ANHAIA MELLO, 1954, p. 09). Por outro, faz referência à corrente de arquitetura orgânica, que ganhava força a partir da década de 1940 com Frank Lloyd Wright e os escritos de Bruno Zevi (IRIGOYEN, 2002, p. 82), contrapondo-se à vertente "racionalista" da arquitetura moderna.

Em 1958, o papel social do arquiteto ganhou evidência ainda maior no programa da disciplina. Do mesmo modo, a questão da arquitetura moderna. O primeiro trabalho era uma prova escrita sobre o tema: "Posição do Arquiteto na sociedade moderna”, bem como a análise das melhores obras modernas brasileiras nos dez anos anteriores. Pela primeira vez a arquitetura moderna apareceu como a única abordada na disciplina, deixando de ser discutida a questão dos estilos, ou do "movimento contemporâneo". O programa do projeto a ser desenvolvido pelos estudantes também se modificou, passando-se de uma residência para um hotel para motoristas e um restaurante à margem de uma estrada de rodagem.

O programa de 1958 sinaliza um momento de passagem, consolidando definitivamente a arquitetura moderna como aquela a ser ensinada, introduzindo-se o debate sobre a função social da arquitetura, o papel do arquiteto perante a sociedade, etc. Pode-se afirmar que, progressivamente, os aspectos sociais e sociológicos começaram a crescer em importância no escopo do ensino de arquitetura, sobrepondo-se às questões estéticas.

Em 1959, o programa habitacional foi substituído por outro tema de trabalho. Propunha-se uma situação hipotética no município de Leme, em que a partir de uma parceria entre os governos estadual e federal visando dar maior desenvolvimento ao folclore paulista, devia ser projetado um centro que pudesse reunir os participantes das festas e danças tradicionais de São Paulo. Devia-se, assim, projetar um equipamento público cultural, voltado para o fortalecimento da cultura popular do Estado de São Paulo. Foi também enfatizado que, tendo em vista o caráter popular do projeto, deveriam ser privilegiados os materiais locais e de fácil manuseamento. A proposta remetia à discussão do papel social do arquite- 
to, do público e do popular em arquitetura. O programa era bastante complexo e envolvia a construção de diversos edifícios, tais como igreja, cinema, posto de serviço, campo esportivo com vestiário, grupo escolar, área comercial, dentre outros. O trabalho dos estudantes se iniciava com um planejamento geral da estrutura, para então passar ao projeto de cada um dos edifícios, para que finalmente fosse apresentado o trabalho completo ao final do ano.

Em 1961, houve um esforço em articular as atividades desta cadeira e o trabalho desenvolvido pelo CPEU, reforçando a inserção do fazer arquitetônico no âmbito de um plano. Dessa forma, "em complemento ao Plano Diretor da cidade de Socorro, elaborado pelo Centro de Pesquisa e Estudos Urbanísticos da Faculdade e desenvolvido pelos alunos do $5^{\circ}$ Ano em 1960, esta Cátedra fará desenvolver projetos de residências, escolas, igrejas, hotéis, zonas comerciais, etc." (grifo nosso). A primeira aula do curso era uma palestra de Anhaia Mello, diretor do CPEU, a respeito do plano de Socorro e "dando aos snrs. Alunos uma primeira noção de planejamento e pondo-os a par das necessidades e reivindicações da população de Socorro". A partir desse plano, optariam os estudantes por desenvolver projetos, entre residências, escolas, zonas comerciais, hotéis e assim por diante. Do mesmo modo que se pretendia trazer pessoas especializadas nos temas do folclore para os alunos de 1959, naquele ano deveriam ser chamados outros professores ou técnicos a fim de palestrarem sobre suas especialidades, relacionadas com os trabalhos propostos.

É possível que a parceria com o CPEU não tenha sido plenamente bem-sucedida. Em 1962, não houve referência aos planos diretores desenvolvidos naquele centro de pesquisa. Ainda se tratava de um equipamento muito mais complexo do que uma pequena residência, porém situado em uma área hipotética nos arredores de São Paulo. O equipamento proposto consistia numa unidade de habitação para 500 operários de fábrica, dispondo de alojamentos para famílias e solteiros, um grupo escolar para pré-primários, um ambulatório, um clube, um campo esportivo, uma área comercial e uma área de lazer. Do mesmo modo que em 1959 , o processo de trabalho previa uma fase de planejamento $\left(1^{\circ}\right.$ semestre) e outra de arquitetura ( $2^{\circ}$ semestre). Conforme mencionamos, houve, de 1961 para 1962, uma redefinição dos objetivos do Departamento de Composição, a partir de um debate entre o corpo docente. Isso transparece em todos os programas daquele ano, que são iniciados com a afirmação de que os trabalhos seriam desenvolvidos conforme as diretrizes traçadas pelo Departamento.

Os programas de 1957 a 1962 explicitam o desejo de projetar para uma cidade dotada de plano diretor ou, ainda, de participar do planejamento da cidade. Essa posição nos remete ao artigo de Niemeyer de 1946, que citamos no capítulo anterior. No texto, o arquiteto criticou a pequena expressão social da arquitetura, avaliando que "a atividade limitou-se à construção de prédios isolados, edifícios públicos e casas burguesas, obras que logicamente deveriam fazer parte de um Plano Diretor, ajustado indistintamente a todos os problemas sociais e urbanísticos". Prenúncio de duas questões importantes naquele momento e dali em diante: a função social do arquiteto e da arquitetura, e a subordinação da arquitetura ao planejamento. Os benefícios da arquitetura moderna, sem o Plano Diretor, ficavam restritos à classe dominante (apud BUZZAR, 1996, p. 196). A esse respeito, Buzzar comentou que

Apesar do conteúdo crítico, eram posturas como esta que deviam estar na base dos ataques de [Demétrio] Ribeiro à arquitetura moderna, na medida em que podiam funcionar como uma espécie de confissão da impossibilidade de se 
ter uma atuação social como arquiteto. Ou seja, não existindo o Plano, apesar da rejeição de um trabalho confinado às elites, a atividade permaneceria restrita a edifícios isolados - evidentemente servindo às elites ou ao Estado (idem, ibidem).

\subsubsection{Cadeira $\mathrm{n}^{\circ}$ 18. Composição de Arquitetura. Grandes Composições - Parte I ( $4^{\circ}$ ano).}

Essa cadeira, ministrada para estudantes de quarto ano, foi responsabilidade, entre 1951 e 1953, de José Vicente Vicari e Hélio Duarte ${ }^{4}$. Em 1958, Roberto Cerqueira César tornou-se o docente titular da cadeira, tendo por assistentes Luiz Roberto de Carvalho Franco, a partir de 1958, e Carlos Millán, a partir de 1959.

Em 1953, foram apresentados dois programas para essa cadeira, sendo um de Hélio Duarte e outro de José Vicente Vicari. O curso de Vicari subdividia-se em três partes. A primeira dizia respeito ao campo teórico de Composição de Arquitetura, retomando os conhecimentos adquiridos ao longo do curso relativos ao desenho arquitetônico, aos aspectos técnicos, funcionais e de estrutura, dentre outros. Apresentava um tópico acerca da "essência estética da arquitetura e essência especifica da construção" e da "personalidade estética do aluno". Segundo o docente, arquitetura e construção distanciavam-se pois a primeira era essencialmente estética e a segunda, essencialmente utilitária. A segunda parte do curso era "prática e material", e compreendia o desenvolvimento de trabalhos sobre temas de projeto "de suficiente determinada complexidade" (edifícios isolados ou em conjunto), "sob pontos de vista regional e nacional, e de ordem arquitetônica, urbanística, construtiva, econômica, técnica, social e humana”. A terceira parte complementava os aspectos teóricos e práticos desenvolvidos.

Hélio Duarte abordava conceitos em torno das Grandes Composições relativos à metodologia de trabalho, à estruturação de partidos e ordenação de grandes massas, ao estudo de circulações coletivas e ao entrosamento entre elementos estruturais e de instalações gerais na composição. Os exercícios propostos para o segundo semestre consistiam no projeto de equipamentos de habitação coletiva ou unidade comercial, visando enfrentar problemas pertinentes ao coletivo e à circulação vertical orgânica; uma unidade de saúde (problema de ordem médico-social) e um edifício escolar (enfrentando especificidades do módulo infantil). Hélio Duarte também lecionou na cadeira em 1956 e 1957, antes de pas-

4 De acordo com Ficher, Ícaro de Castro Mello e Oswaldo Corrêa Gonçalves ocuparam essa cadeira em 1954. Existe um ofício da diretoria da FAUUSP em que se afirma que Zenon Lotufo foi o responsável pela cadeira em 1955, tendo por assistente Manoel da Silva Machado. 
sar a lecionar na cadeira $\mathrm{n}^{\circ} 16$. O curso era constituído de aulas informativas sobre planos de massa, a atitude do arquiteto frente ao problema das grandes composições, do plano, de aspectos estéticos e plásticos e discussão e análise de grandes planos executados. Nas aulas práticas, fazia-se o estudo gráfico de programas pertinentes às grandes composições (educação, saúde, transporte e indústria) e a análise crítica de obras de arquitetos renomados e de um projeto desenvolvido por cada aluno.

A partir de 1958, Roberto Cerqueira César passou a ser o docente responsável pela disciplina. A parte teórica da disciplina voltava-se para o estudo de elementos técnicos, funcionais e plásticos da arquitetura, buscando sistematizar o conhecimento adquirido nas cadeiras técnicas da faculdade e aplicá-los no projeto de arquitetura. Havia a preocupação em familiarizar os estudantes com problemas de caráter urbanístico, procurando trabalhar em conjunto com a Cadeira de Urbanismo. O trabalho era desenvolvido com a colaboração do CPEU, tal como se observou na Cadeira $n^{\circ} 17$, e se dava em quatro fases. A primeira, de pesquisa, consistia em estabelecer o programa em função das condições e necessidades locais, a partir do levantamento de dados estatísticos. Na segunda fase, os alunos deveriam apresentar o anteprojeto do conjunto, indicando a localização das funções e dos edifícios, estabelecendo a circulação, os acessos e o entrosamento com o plano geral da comunidade. A partir disso, distribuía-se entre os estudantes, na terceira fase, o projeto a ser desenvolvido por cada um e, finalmente, fazia-se a revisão do plano de conjunto tendo em vista o projeto dos edifícios.

Em 1959, definiu-se que o ponto de partida dos trabalhos seria o Plano Diretor de Águas da Prata, elaborado pelo CPEU. Com base no plano, foram apresentadas as seguintes questões a serem trabalhadas: Abastecimento, Transporte e Tráfego, População Flutuante, Produção, Estância Hidromineral, Recreação e Esporte, Centro Cívico. Deveria ser escolhido um tema por equipe de alunos, a ser investigado na base de dados das pesquisas do CPEU, que deveria resultar em um roteiro de trabalho para a realização do exercício de composição, que consistia em "um conjunto urbano". Em 1961, abandonando a alusão ao CPEU, o docente trabalhou com o tema da assistência hospitalar a uma comunidade. Ainda assim, o procedimento de trabalho não sofreu grandes alterações, isto é, os alunos deveriam proceder ao levantamento de dados e organização do programa (a partir do estudo de equipamentos existentes, previsão das necessidades atuais, situação da comunidade no plano estadual e regional) para então apresentar o projeto dos edifícios previstos.

Em 1962, a partir das diretrizes traçadas pelo Departamento, a cadeira previa duas linhas de trabalho. A primeira era relacionada com o projeto arquitetônico em si, enfatizando a relação com a realidade urbanística. Explicitava-se, porém, que não deveriam ser realizados planos urbanísticos, responsabilidade da cadeira de urbanismo ${ }^{5}$. A segunda linha, trabalhada no âmbito da disciplina de "Plástica", tratava do Desenho Industrial, "especialmente no que se refere à indústria da construção e ao estudo do desenvolvimento de implementos e equipamentos do edifício". É interessante notar que tal alteração ocorreu

5 A aproximação, seguida de distanciamento dos trabalhos do CPEU, visível nos programas das Cadeiras de Grandes Composições indicam a possibilidade de que tenha havido um conflito entre as cadeiras de composição e de urbanismo, a partir do momento em que se procurou articulá-las. Entretanto, não foram localizadas evidências empíricas dessa hipótese. 
na disciplina de Plástica III, subordinada àquela cadeira, progredindo da lógica da composição para a do campo do desenho industrial. De 1958 para 1959, começou a se processar uma mudança no conteúdo trabalhado. Se em 1958 ainda eram abordados os "problemas arquitetônicos de caráter essencialmente plástico" sob o ponto de vista de materiais, textura, cor e técnicas diversas, a proposta para 1959 era de projetar objetos sugeridos pelo tema geral trabalhado, tais como os equipamentos dos locais de recreio, assim como de realizar o projeto de exposição dos trabalhos. Em 1961, além de atividades de apoio para o projeto a ser realizado na cadeira de grandes composições, propunha-se a elaboração de trabalhos de desenho industrial em colaboração com a cadeira de Produção Industrial da Escola Politécnica, a cargo do Prof. Ruy Aguiar da Silva Leme. Finalmente, em 1962, os estudantes desenvolveram um estudo que partia da crítica da produção existente para elaborar um protótipo, prenunciando o método que seria adotado na Sequência de Disciplinas de Desenho Industrial da FAUUSP a partir de 1963.

\subsubsection{Cadeira $n^{\circ}$ 19. Composição de Arquitetura. Grandes Composições - Parte II (5ªno).}

Essa cadeira era ministrada aos estudantes do quinto ano. Em 1952 e 1953, foi responsabilidade de Elisário da Cunha Bahiana. Entre 1954 e 1959, Rino Levi foi o seu titular, tendo por assistentes Roberto Cerqueira César (1954-1957) e Artigas (1958-1959). A partir de 1960, com a saída de Rino Levi da FAUUSP, Artigas tornou-se o docente responsável pela cadeira.

De acordo com o programa de 1953, a disciplina dividia-se em duas partes que versavam, respectivamente, sobre projetos completos de conjuntos de edifícios e sobre edifícios de grandes proporções. Diferentemente da abordagem de outros docentes, dentre os quais José Vicente Vicari, que defendia a adoção de temas relativos ao cotidiano dos estudantes, nessa matéria os estudantes deviam trabalhar com programas de edifícios monumentais.

Em 1957, quando Rino Levi já era o docente responsável, havia duas propostas distintas. A primeira visava o entrosamento com a Cadeira de Estabilidade e Estruturas e consistia em desenvolver o anteprojeto e a maquete de uma ponte de $310 \mathrm{~m}$. A segunda era projetar uma rede hospitalar para o Estado de São Paulo. O projeto articulava-se com o Instituto de Pesquisas Hospitalares, responsável por fornecer dados e promover palestras de especialistas em vários assuntos ligados ao tema.

Em 1958, a disciplina trabalhou com base no Plano Piloto de Taubaté, realizado pelo $\mathrm{CPEU}^{6}$. Sem perder de vista a visão global da cidade e sua inserção regional, eram pro- 
postos 10 temas de projeto, dentre os quais: Centro Administrativo, Cultural e Recreativo; Planos de Saúde e Educação; Abastecimento; Centro Esportivo; Habitação; e Problemas Ferroviário, Rodoviário ou Aeroviário. O processo de trabalho dos estudantes iniciava-se com um estudo preliminar baseado no Plano Piloto, na escala de 1:10.000. Eles faziam, então, uma proposta de implantação dos edifícios e das obras complementares, com indicação das soluções arquitetônicas e paisagísticas (escalas 1:500, detalhes em 1:200). Em seguida, devia ser apresentado o anteprojeto, com a organização do programa definitivo e, por fim, entregava-se o projeto completo. Em $1959^{7}$, trabalhou-se com o município de Águas da Prata, de forma muito semelhante ao que se fez na Cadeira $n^{\circ} 18$, elegendo, apenas, temas distintos: Abastecimento (mercados, centro rural de abastecimento, cooperativas agropecuárias); Transporte e tráfego (estação ferroviária e estação rodoviária); População flutuante (hotéis, unidades residenciais especiais, condomínios); Produção (monopólio estatal de água); Estância hidromineral (assistência médica, fisioterapia); Recreação e esporte (clubes, centro esportivo); Centro cívico (administração municipal, estadual e federal, comércio, cultura e recreio, casa da lavoura).

Em 1961 e 1962, o professor dessa disciplina era Artigas. A estrutura do programa não se alterou com relação àquela adotada por Rino Levi e Roberto Cerqueira César em 1959. Contudo, a escolha da cidade-tema era feita pelos estudantes, que eram incentivados a escolher municípios do interior do Estado. Eles deviam estudar aspectos relativos a abastecimento, transporte e tráfego, população flutuante, produção [economia], estância hidromineral ${ }^{8}$, recreação e transporte e Centro Cívico. Consta no programa que a base de dados do CPEU deveria ser consultada na etapa de pesquisa e de escolha do tema a ser trabalhado.

Em 1961, tanto Abelardo de Souza quanto Roberto Cerqueira César, em suas respectivas cadeiras, abandonaram a proposta de trabalhar em municípios do interior de São Paulo, distanciando-se da parceria com o CPEU. Artigas, entretanto, manteve o incentivo a essa aproximação no programa de sua disciplina, estimulando a realização de trabalhos para municípios para os quais o CPEU tivesse desenvolvido pesquisas e planos.

7 Artigas foi o docente interinamente responsável pela disciplina em 1959, pois Rino Levi encontrava-se afastado em viagem à Venezuela.

8 Embora o programa da disciplina não definisse o município em que os estudantes deveriam trabalhar, a "Estância Hidromineral" aparecia como um tema de pesquisa, o que poderia ser uma forma de estimular os estudantes a escolherem cidades objeto de planos do CPEU (os planos diretores realizados pelo CPEU foram contratados com base no Decreto Estadual 28.399/1957, que exigia a realização de planos diretores para esses municípios). 


\subsubsection{Considerações sobre o ensino de Composição de Arquitetura na FAUUSP}

Nos anos 1950, era efervescente o debate sobre o ensino de arquitetura, que refletia questões maiores, tais como o sentido da "arquitetura nacional", o "papel social do arquiteto", "arquitetura e industrialização", dentre outros. Na FAUUSP, ao mesmo tempo em que a discussão se processava, as disciplinas de Composição de Arquitetura foram também se transformando. Vale observar que a própria questão dos estilos arquitetônicos ou da existência de um "estilo moderno" ou contemporâneo não estava superada a princípio. Ao longo dos debates nos meios acadêmico e profissional, a Arquitetura Moderna foi se afirmando como o paradigma que deveria embasar a formação dos alunos. Também foram os arquitetos filiados à arquitetura moderna aqueles que perduraram à frente do ensino, sendo que outros, como Elisário da Cunha Bahiana, ou mesmo José Vicente Vicari, menos envolvidos com a corrente hegemônica da arquitetura moderna, se distanciaram da faculdade.

$\mathrm{Na}$ tentativa de superar o "método compositivo", passaram a emergir, no processo de formação, preocupações relativas à responsabilidade social do arquiteto, ao "popular", à relação entre arquitetura e planejamento urbano e à função do edifício. De modo que os programas de Pequenas Composições e Grandes Composições, no final da década, apresentavam propostas de trabalho muito semelhantes. É notável o esforço em inserir o projeto do edifício em um contexto urbano mais amplo, tendo em vista o plano, como uma resposta possível para desempenhar-se o papel social do arquiteto. Se Anhaia Mello, na Escola Politécnica, parece ter dado menor importância à arquitetura, privilegiando o ensino do urbanismo, os docentes de Composição na FAUUSP também subordinaram a arquitetura ao plano, buscando materializá-lo.

No que se refere ao tratamento dado à questão da habitação, se comparados os programas das disciplinas ministradas na FAUUSP com aqueles ensinados por Anhaia Mello na Escola Politécnica, a diferença é muito significativa. Os temas trabalhados referiam-se a “pequenas residências”, "palacetes”, "pequenos edifícios de apartamentos”, eventualmente um "conjunto operário", ao passo que na FAUUSP a habitação como uma questão social passou a ser tratada de forma muito mais incisiva.

Mais adiante, vamos explorar as diferentes noções de plano de Artigas e Anhaia Mello, procurando evidenciar como isso repercutiu na construção da relação entre arquitetura e urbanismo na FAUUSP. O projeto de edifícios públicos se constituía como o ponto em comum entre duas estratégias diferentes e independentes: a da afirmação do campo de arquitetura moderna, e a da afirmação do campo de urbanismo. Outra possibilidade apresentada por Abelardo de Souza, além da colaboração com o CPEU, consistiu na grande estrutura multifuncional. A aproximação com os trabalhos do CPEU e a disciplina da Cadeira de Urbanismo se deu em 1959. Em 1961, já não havia o entrosamento com o centro de pesquisa, embora a abordagem ou o programa se mantivessem semelhantes (análise do contexto urbano, estadual e regional; elaboração do projeto em função do estudo dessa realidade, projeto dos equipamentos assinalados no plano). 


\subsection{Do urbanismo ao planejamento}

A cadeira de urbanismo da FAUUSP foi ocupada por Anhaia Mello desde o início de suas atividades até sua aposentadoria, em 1961, quando Lauro Bastos Birkholz assumiu-a. Em 1952, Milton Ghiraldini foi contratado como assistente de Anhaia Mello. Roberto José Goulart Tibau também assistiu a cadeira. Em 1962, após a saída de Anhaia Mello, José Cláudio Gomes e Brenno Cyrino Nogueira vieram incrementar o corpo docente. Após a contratação de Lauro B. Birkholz pelo CPEU em 1957, ele tornou-se assistente de Anhaia Mello na cadeira de urbanismo. Quando o catedrático aposentou-se, Lauro assumiu também assumiu a responsabilidade por ela, que a partir de 1963, teve seu nome alterado para Planejamento II, integrando a Sequência de Planejamento do curso de arquitetura e urbanismo. A cadeira de Planejamento I ficou a cargo de Roberto Coelho Cardozo.

\subsubsection{Cadeira de Urbanismo (1953-1962)}

O programa do curso de urbanismo da FAUUSP manteve-se muito semelhante àquele que Anhaia Mello adotava na Escola Politécnica desde os anos 1930․ Iniciava-se com uma "introdução ao urbanismo", com apresentação de conceitos e definições. Em seguida, tratava de aspectos históricos do processo de urbanização, do crescimento urbano, da "cidade tentacular", de aspectos de sociologia urbana, das relações entre cidade e campo, dentre outros. O terceiro tópico dizia respeito ao "Governo Municipal" (até 1953, este tópico recebia o nome de "Cidade: problema de governo") ${ }^{10}$. Em seguida, o curso abordava o tema das finanças municipais ${ }^{11}$, da avaliação dos imóveis urbanos ${ }^{12}$, da economia da terra

9 Tivemos acesso aos programas da Cadeira de Anhaia Mello do curso de engenheiros arquitetos para os anos de 1937 a 1939, 1941, 1943. No curso da FAUUSP, acessamos os programas de urbanismo para os anos de 1953, 1956 a 1959 e 1962 e de planejamento de 1965 a 1969.

10 Sobre esse assunto, Anhaia Mello publicou no Boletim do Instituto de Engenharia os artigos: "A cidade, problema de governo" (1928) e "O governo das cidades" (1929).

11 Assunto tratado, dentre outros, no artigo "Urbanismo: o problema financeiro", publicado no Boletim do Instituto de Engenharia (1929).

12 Ver "Methodo de Avaliação dos terrenos urbanos", na Revista Politécnica n 91, de 1929. 
urbana $^{13}$. O sétimo tópico tratava da legislação do urbanismo moderno ${ }^{14}$. Os oitavo, nono e décimo tópicos abordavam aspectos relativos ao plano, respectivamente: organização de um plano de desenvolvimento; planos regionais; elementos físicos de um plano (estáticos e dinâmicos $)^{15}$. O décimo primeiro tópico tratava de problemas específicos de desenvolvimento local. O décimo segundo estava voltado para o estudo da Cidade Jardim (e da apresentação dos exemplos de Letchworth, Welwyn e Wythenshawe). O décimo terceiro tratava da "dinâmica do plano" e o décimo quarto, do "problema econômico-social dos serviços de utilidade pública" ${ }^{\prime 16}$. Através da análise dos programas das disciplinas de Anhaia Mello ao longo do tempo e das publicações de sua autoria em revistas especializadas, constatamos duas coisas: que o programa, em sua estrutura, não se alterou durante todo o período em que Anhaia Mello esteve na docência, na Escola Politécnica e na FAUUSP, e que suas ideias urbanísticas, repercutindo no conteúdo de suas aulas, já estavam definidas entre fins dos anos 1920 e o início dos anos 1930. Apenas alguns aspectos foram acrescentados nos anos 1950, na FAUUSP. Na introdução ao urbanismo, foram acrescentadas, em 1957, a "Carta de Atenas" e em 1958, a Charte de l'Aménagement de Economia e Humanismo. Na apresentação da Carta dos Andes, de 1960, Anhaia Mello afirmou que esses documentos consistiam nas bases do urbanismo moderno (ANHAIA MELLO, 1960, s/n).

A partir de 1957, ano de início das atividades do CPEU, o programa da Cadeira passou a explicitar as especificidades das profissões de arquitetura e de engenharia em relação ao urbanismo, em um contexto em que essa disciplina era ensinada como ciência multidisciplinar. Tratava-se assim de apresentar aos estudantes "o urbanista, sua formação profissional e responsabilidade". A partir daquele ano deu-se preferência ao termo "planejamento" para definir a ciência responsável por tratar das questões urbanísticas. A equipe de planejamento devia ser constituída por especialistas em matérias tão diversas quanto a geologia e a sociologia e deveria ser coordenada por um arquiteto ou um engenheiro. Essa ideia também havia sido desenvolvida em uma conferência realizada na Associação

13 Anhaia Mello publicou, na Revista Politécnica, quatro artigos intitulados "A Econômica da Terra Urbana", entre 1932 e 1933.

14 Sobre o assunto ver, entre outros, “Urbanismo - Regulamentação e Expropriação”, publicado no Boletim do IE em 1929.

15 Foram também publicados diversos artigos do autor abordando a questão dos planos. Dentre eles: "Urbanismo e suas normas para a organização do plano", em Boletim do IE de 1933. "O National Planning Board e Plano Nacional dos Estados Unidos” (Boletim do IE, 1937), Pierre Charles l’Enfant e o plano da Cidade Federal (Boletim do IE, 1937).

16 Em 1930, foram publicados quatro artigos de Anhaia Mello tratando dessa questão no Boletim do Instituto de Engenharia. Os artigos se intitulavam, respectivamente: "Natureza, classificação e característicos econômicos dos serviços de utilidade pública”, "O problema do lixo em São Paulo", "Regulamentação dos Serviços de Utilidade Pública - os meios de proteção do interesse público", "Regulamentação dos serviços de utilidade pública". Em 1934, o Boletim do IE publicou, em três partes, um artigo intitulado "Novos subsídios para regulamentação dos serviços de utilidade pública". Foi também publicada uma coletânea em 1940 - "O problema econômico dos serviços de utilidade pública". 
de Engenheiros de Santos em dezembro de 1956, por ocasião da comemoração do "Dia do Engenheiro e do Arquiteto", publicada na Revista Habitat em janeiro de 1957. No artigo, intitulado "Planejamento, arquitetura, engenharia: contrastes e confrontos", Anhaia Mello optou pelo termo "planejamento" e "planejador" em detrimento de "urbanismo" e "urbanista", por considerar que a abrangência do plano ultrapassava o âmbito da cidade, "urbs". O docente procurou situar o papel de cada um dos três profissionais no processo de realização de planos, que de acordo com ele realizavam planos complementares, sendo que o "plano dos planos", integrador (municipal, regional, nacional, internacional) cabia ao planejador. Anhaia Mello defendia que nem arquitetos nem engenheiros poderiam deter o monopólio da elaboração de "planos de ordenação territorial", por se tratar de matéria que envolvia problemas de ordem social e não técnica, cabendo aos técnicos "interpretar o diagnóstico em termos de estruturas tridimensionais". Sua inquietação em situar o papel da arquitetura e engenharia no âmbito do planejamento se apresentava como uma resposta às discussões mobilizadas pelos arquitetos naquele momento, que reivindicavam o urbanismo como atribuição exclusiva da categoria.

Após a criação do CPEU, o programa da disciplina de urbanismo da FAUUSP incorporou a metodologia adotada pelo centro de pesquisa, que também havia sido publicada em "Elementos para o planejamento territorial dos municípios", de autoria de Anhaia Mello.

\subsubsection{Cadeiras de Planejamento (a partir de 1963)}

Em 1963 as cadeiras de urbanismo e de arquitetura da paisagem deram lugar à Sequência de Planejamento (Planejamento I, para alunos de $3^{\circ}$ ano, e Planejamento II, com disciplinas para estudantes de $4^{\circ}$ e $5^{\circ}$ anos). $O$ programa passou por reestruturações, embora tenha preservado, em parte, o modelo de Anhaia Mello, sempre incorporando elementos da metodologia do CPEU.

Com a reforma, a cadeira de Planejamento I visava "dar introdução ao planejamento com temas ligados ao projeto", o que era entendido como o emprego de "temas ligados à arquitetura paisagística, colaborando com as cadeiras de Composição (sic) em regime de Atelier" (Programa da Cadeira de Planejamento I de 1965). No segundo semestre, propunha-se a integração vertical dos estudantes com temas de planejamento relativos à cidade de São Paulo, com vistas a uma aplicação prática. Para tanto, contava-se com uma parte teórica de "introdução ao planejamento", que versava sobre "arquitetura paisagística". De modo que o ponto de contato entre o planejamento urbano e a arquitetura parecia residir na arquitetura da paisagem. Na realidade, Planejamento I viera substituir a cadeira de "Arquitetura da Paisagem", ministrada anteriormente à reforma de 1962. Tanto que, antes e depois da reforma, essas cadeiras foram dirigidas pelo mesmo docente, Roberto Coelho Cardozo. 
Nos quarto e quinto anos os alunos seguiam a cadeira de Planejamento II, tendo à frente Lauro Birkholz. Na introdução do programa, informava-se que o objetivo era "a formação teórico-prática do arquiteto para o planejamento territorial nos seguintes campos: urbano, municipal e regional (intermunicipal)" (Programa de 1966). A formação teórica contava com o estudo das principais correntes e tendências do planejamento territorial contemporâneo e seus fundamentos econômicos e sociais ${ }^{17}$. A formação prática, que exigia "uma posição correta em face da teoria do planejamento territorial”, consistia na elaboração de projetos ou planos territoriais a partir de problemas reais ligados ao Estado de São Paulo. Portanto, tudo indica que as atividades do CPEU tiveram grande influência sobre o processo de formação dos estudantes.

Quanto aos exercícios, para o quarto ano eram propostos dois temas de menor complexidade e para o quinto ano um tema-tese único. O esforço de entrosamento com as demais sequências de disciplinas do departamento, especialmente as de projeto, era explicitado. Além disso, mencionava-se que o CPEU teria o papel de assessorar os estudantes no desenvolvimento dos trabalhos, através do fornecimento de dados e pesquisas e de orientações para a pesquisa.

Após o Fórum de Ensino de 1968, o planejamento passou a ser lecionado desde o $2^{\circ}$ ano. Os programas de disciplinas indicam que houve uma aposta ainda mais decisiva na integração vertical: para 1969 foram propostos pelo departamento de projeto pelo menos três ciclos de trabalhos envolvendo alunos dos vários anos. Um desses ciclos visava trabalhar com a temática do planejamento metropolitano (de 20 a 24 de outubro de 1968), com a participação de todas as sequências de disciplinas do departamento de projeto. Os trabalhos eram acompanhados pelos professores da Sequência de Planejamento, Lauro Birkholz e Roberto Cardozo, e pelos coordenadores Abelardo Riedy de Souza (coordenador do $3^{\circ}$ e $4^{\circ}$ anos), Hélio Queiroz Duarte (coordenador do $2^{\circ}$ ano), além dos professores: Cândido Malta Campos Filho, José Cláudio Gomes, Milton Ghiraldini, Brenno C. Nogueira ${ }^{18}$, Miranda Maria Magnoli, Antonio A. Antunes Neto e Marco Souza Dias.

Além da integração entre os diferentes anos, também se procurou apresentar temas de trabalho, para cada ano, em que fossem mobilizados os conhecimentos relativos às várias sequências de disciplinas do Departamento de Projeto. Foi proposto um curso básico de planejamento urbano voltado para alunos de primeiro a quarto anos que devia mobilizar todo o corpo docente relacionado com os assuntos trabalhados. O primeiro ano estudou o "espaço urbano elementar", através de um "projeto de praça pública e seu equipamento coletivo". Assim, além de projeto e planejamento, foram também abordados os aspectos de comunicação visual e desenho industrial. No segundo ano, estudou-se a tipologia dos edifícios, sob o tema "projeto de edifícios públicos". O terceiro ano lidou com a "renovação de áreas urbanas - os centros urbanos e os edifícios públicos dos espaços urbanos”. Os alunos deviam trabalhar em um "projeto de área urbana, incluindo um centro urbano e projeto dos edifícios correspondentes”. Por fim, no quarto ano, estudou-se o planejamento urbano, rural e regional, por meio da realização de um "projeto regional". Portanto, a interface entre as

17 A especificação de quais eram as tendências, no entanto, não foi detalhada no programa.

Brenno Cyrino Nogueira, formado na FAUUSP em 1957, participava das atividades do CPEU 
sequências de planejamento, projeto, desenho industrial e comunicação visual era o projeto do espaço público (praça) devidamente equipada e os edifícios públicos, que foram objeto de estudo na escala do edifício e na escala dos conjuntos urbanos.

Para os alunos de segundo ano, a cadeira de planejamento estava a cargo dos instrutores Antônio Augusto Antunes Netto e Marcos Souza Dias. O curso versava sobre a conceituação do planejamento físico (plano e projeto), buscando situar o papel do arquiteto na equipe de planejamento. Definia-se uma determinada região, para a qual deveriam ser estudados os fatores sociais e econômicos, a estrutura urbana, os transportes, os diagnósticos setoriais (serviços de utilidade pública e equipamentos sociais) e os aspectos relativos à implantação do planejamento (finanças, legislação, organização e administração).

Além disso os alunos de segundo ano deviam elaborar um trabalho prático a partir do "Estudo do Problema de uma Feira Livre Urbana", abordando assim a questão do abastecimento urbano. Com base em aulas teóricas e pesquisas bibliográficas os estudantes avaliavam qual seria a melhor política de planejamento aplicável ao assunto. Essa atividade era coordenada pelo professor Hélio Duarte, contando também com os professores da Sequência de Planejamento: Lauro B. Birkholz, Antonio Antunes Neto, Marcos de Souza Dias e Brenno Cyrino Nogueira.

A disciplina de "Planejamento I", para os alunos de terceiro ano, em 1969 tinha por tema o Planejamento de um Núcleo Habitacional e era ministrada por Brenno Cyrino Nogueira e Milton Ghiraldini. O trabalho consistia em planejar uma zona habitacional para 20.000 habitantes nas áreas marginais ao Rio Pinheiros. A localização e o tamanho da área poderiam ser definidos pelos estudantes, de acordo com densidades de ocupação pré-fixadas pelas equipes, que deveriam atender às melhores taxas de ocupação do solo. Além disso, o programa estabelece que os estudantes poderiam adotar as diretrizes organizadas no Plano Urbanístico Básico, recém-apresentado, ou então estabelecer novas diretrizes. Assim, após sucessivas reformulações ocorridas na década de 1960, em 1969, Planejamento I não se voltava mais exclusivamente para questões paisagísticas.

No quarto ano, a disciplina era ministrada pelo instrutor Roberto José Goulart Tibau. O tema era "Arquitetura dos Grandes Complexos Urbanos. Projeto de uma Área Habitacional no Vale do Rio Pinheiros". Tratava-se, portanto, de tema análogo ao proposto aos alunos de $3^{\circ}$ ano. O que diferenciava a disciplina era uma exigência de clareza quanto aos conceitos e metodologias a serem empregados. A definição do local, por exemplo, deveria levar em consideração fatores como: área disponível, vinculação aos elementos urbanos existentes e as vias de comunicação. O plano devia prever a organização do sistema viário e relacionar as diversas funções urbanas. O programa abordava também a questão da flexibilidade (oposição entre conjunto estático - arquitetura como cristal e conjunto dinâmico - arquitetura como organismo evolutivo). 


\subsubsection{Considerações sobre as disciplinas de urbanismo e planejamento}

A cadeira de urbanismo parece ter se mantido estável ao longo do tempo, desde sua origem na Escola Politécnica até sua transferência para a FAUUSP. Em seguida à aposentadoria de Anhaia Mello, muito do conteúdo programático adotado pelo docente parece ter sido perpetudado. Grande parte dos conteúdos da Cadeira de Planejamento II destinavam-se à transmissão da metodologia do CPEU e ao desenvolvimento de atividades ligadas aos trabalhos do centro de pesquisa, o que fica claro quando se confronta a documentação dos Boletins do CPEU e os programas das disciplinas.

As maiores transformações na cadeira parecem ter ocorrido a partir do Fórum de 1968, quando houve também uma diversificação do corpo docente. Isso coincidiu com a avaliação dos profissionais do CPEU de que a partir dessa reestruturação curricular a continuidade das atividades do centro de pesquisa ficou comprometida dentro da FAUUSP (BIRKHOLZ \& NOGUEIRA, 1993, p. 90). Em suma, a análise dos programas dos anos 1950 e 1960 indicam que a reforma curricular de 1962 parece ter produzido poucos efeitos mais profundos nessas disciplinas, apesar da substituição do docente responsável.

Por fim, deve-se destacar que apesar de um possível impasse na articulação entre o CPEU e as disciplinas de composição no fim da década de 1950, durante os anos 1960 foram propostos trabalhos de integração entre as quatro sequências do departamento de projeto. Destacamos que a interface entre as várias áreas de estudo envolvidas se dava pela adoção de temas como o projeto do espaço urbano público e equipado, o projeto de edifícios públicos e o projeto de zonas habitacionais.

\section{0 "plano" como a interface entre arquitetura e urbanismo}

Analisando os programas das disciplinas de composição da FAUUSP nos anos 1950, especialmente após a criação do CPEU, evidenciou-se que os docentes daquelas cadeiras pretendiam fazer a interface entre arquitetura e urbanismo por meio do "plano". A partir de agora iremos observar o entendimento desse instrumento para Artigas e Anhaia Mello, procurando demonstrar que, apesar de um vocabulário comum que parecia favorecer um diálogo entre os dois campos, esse termo remetia a conceitos distintos para cada um desses profissionais. Isso colabora para esclarecer importantes diferenças entre eles, que ainda não foram discutidas. 
Embora Artigas sempre tenha se mantido reverente e respeitoso ao referir-se a Anhaia Mello, ele não pode ser considerado um simples seguidor ou "discípulo" do catedrático. Analisando os trabalhos de urbanismo do arquiteto, observamos um rompimento com as ideias de seu mestre, decorrente, principalmente, da influência da vertente da arquitetura moderna ligada a Le Corbusier. Embora Artigas tenha se declarado alianhado com a vertente germânica, que fundou a Bauhaus, observa-se uma forte influência do arquiteto franco-suíço em suas posições sobre urbanismo, especialmente no que se refere à relação com o Estado.

Antes, contudo, é necessário voltar às origens do urbanismo moderno, de modo a identificar as referências que influenciaram esses profissionais.

\subsection{Antecedentes: o urbanismo no âmbito do Movimento Moderno em Arquitetura}

Em meados do século XIX, a necessidade de controle dos novos problemas urbanos e a possibilidade da racionalização técnica da construção modificou o pensamento e os projetos de urbanistas como Idelfons Cerdà em Barcelona (1859) ou Haussmann em Paris (1850). Em seguida, surgiram propostas alternativas para as cidades industriais em diversos locais da Europa, elaboradas por engenheiros como Arturo Soria y Matta, (Cidade Linear, 1882), por arquitetos como Tony Garnier (Cidade Industrial, 1904) e mesmo profissionais de outras áreas, como Ebenezer Howard (Cidade Jardim, 1898) ${ }^{19}$. Paralelamente, na Alemanha, uma experiência inédita surgida da associação de industriais, artistas e arquitetos passava a produzir uma arquitetura voltada para a construção racionalizada, apoiando-se

19 A Cidade Linear de Soria y Mata, propunha romper com a organização concêntrica da cidade, como resposta aos congestionamentos da cidade tradicional, organizando-a ao longo de um eixo ferroviário de comprimento indefinido e extensível, que reuniria diversas das cidades puntiformes então existentes. A Cidade Industrial proposta por Garnier era organizada através do zoneamento funcional integrado pelo sistema de transporte sobre trilhos, caracterizada pelo valor normativo dos fatores higiênicos, pela separação da circulação de veículos e pedestres, e se apoiava no conceito de cidade-parque, temas que seriam de grande relevância no debate posterior da arquitetura moderna. Ebenezer Howard, que era funcionário público, concebeu a Cidade Jardim visando alcançar uma relação harmônica entre a cidade e o campo, limitando o crescimento urbano por um cinturão verde e prevendo o controle comunitário da terra (BENEVOLO, 2006, p. 330-344 e p.356-364). 
em processos de padronização e pré-fabricação para oferecer um melhor padrão de moradia operária (Deutscher Werkbund, 1907) ${ }^{20}$.

Sob influência dessas experiências foram propostas alternativas à cidade tradicional a partir da união entre "arte" e "técnica" (BENEVOLO, 2007, p. 615), recorrendo-se à programação racional da construção e da organização do espaço. Para Benevolo, os mestres da arquitetura moderna - Gropius, Le Corbusier e Mies Van der Rohe - foram os primeiros a tentar introduzir esse método na prática do projeto da edificação e da cidade, especialmente a partir dos anos 1920. Ao longo desse processo, houve divergências profundas entre as propostas defendidas por cada arquiteto, marcadas por suas visões políticas e pelas circunstancias dos locais de onde atuaram ${ }^{21}$.

Assim, a busca por soluções para a cidade industrial foi um tema privilegiado do Movimento Moderno em arquitetura. Uma das vertentes mais difundidas foi liderada por Le Corbusier, que traçou uma linhagem da renovação da arquitetura e do urbanismo que partia de Tony Garnier, autor de La Cité Industrielle, 1904, e passava por Auguste Perret, que renovara a estética das construções com a técnica do concreto armado. A esse percurso, o arquiteto acrescentou seu próprio estudo para "une ville contemporaine de trois milions d habitants", de 1922, em que desenvolveu temas como a célula de habitação, o loteamento racional e a separação funcional da cidade (LE CORBUSIER, 1977, p. 40). Os CIAM, criados em 1928, especialmente o quarto congresso, de 1933, que resultou na elaboração da Carta de Atenas, sistematizaram esse urbanismo moderno.

\subsubsection{La Cité Industrielle, Tony Garnier}

O projeto de uma Cité Industrielle foi concebido na Académie de France em Roma, entre 1899 e 1904, quando Tony Garnier foi pensionnaire da École des Beaux Arts francesa, depois de vencer o Prix de Rome em 1898. Todavia, somente em 1917 a obra foi publicada, com algumas modificações com relação ao projeto de 1904. Nos anos 1930, por ocasião da publicação de uma nova edição da Cité de Garnier, Morancé e Badovici defenderam que o arquiteto francês teria sido o primeiro a empregar os "sete pontos" da arquitetura moderna,

20 A Deutscher Werkbund foi constituída a partir da reunião de profissionais com visões bastante distintas acerca de questões como a relação entre arte e indústria. A habitação operária foi um dos temas tratados pelo grupo, assim como os edifícios industriais e o desenvolvimento de uma estética da indústria (FRAMPTON, 1993, p.114-116).

21 Analisando os CIAM, Barone (2002) revela importantes diferenças entre os seus membros, comprovando que não se tratava de modo algum de um movimento homogêneo. 
difundidos por Le Corbusier: pilotis, teto-terraço-jardim, supressão de elementos decorativos, janela horizontal contínua, panos de vidro, aquecimento elétrico e isolamento isotérmico (MORANCÉ e BADOVICI, s.d., p. 06).

Tony Garnier domina em seu grau mais elevado o sentido da vida social indispensável a toda grande obra e o rigor científico que é a virtude fundamental do arquiteto. A observação dos grandes movimentos que se delineiam sob a angustiada desordem do nosso tempo levou-o a concluir que o mundo caminha em direção a uma civilização fundada sobre uma base infinitamente maior do que a do passado e em direção a um classicismo em que, pela primeira vez, serão traduzidas a influência preponderante das massas e o papel primordial do trabalho (MORANCÉ Q B BADOVICI, s.d, p.o6) 22 .

Como o nome indica, a Cité industrielle procurava apresentar uma solução para as cidades no contexto da industrialização. Filiado aos valores do socialismo utópico, extraiu de Saint-Simon o entusiasmo pelas virtudes da mecanização; de Fourier a visão de uma idade de ouro agrária harmoniosa, fecunda e apaixonada; e do neo-classicismo do fim do século, perpetuou a confusão de todas as correntes ideológicas em uma nostalgia da arcádia (VIDLER, 1990, p. 79). Ao mesmo tempo, demonstrava confiança no triunfo da técnica. Tais valores constituíam o programa ideológico de uma cidade em que, segundo o próprio Garnier indicou, "cada um percebe que o trabalho é a lei humana e que há bastante ideal no culto da beleza e da bondade para tornar a vida esplêndida"23 (apud VIDLER, 1990, p. 79). Frampton sintetizou a Cité Industrielle de Garnier da seguinte maneira:

Era, sobretudo, uma cidade socialista sem muros ou propriedade privada, sem igreja ou quartéis, sem delegacia de polícia ou tribunal de justiça; uma cidade onde todas as áreas não-construídas eram parques públicos. Dentro da área construída, Garnier acabou por estabelecer uma tipologia variada e abrangente das moradias, segundo padrões estritos do uso de luz, ventilação e áreas verdes. Esses códigos e os padrões combinatórios que geraram eram articulados por uma hierarquia de ruas arborizadas de diferentes larguras. Com uma altura média de apenas dois andares, um planejamento assim aberto resultava em baixa densidade, e, em 1932, Garnier concebeu uma complementação de

22 Texto original em francês, tradução livre da autora: “Tony Garnier possède au plus haut degrée le sens de la vie sociale indispensable à toute grande oeuvre et la rigueur scientifique qui est la vertu fondamentale de l'architecte. L'observation des grands mouvements qui se dessinent sous le désordre angoissé de notre temps l'a amené à conclure que le monde est en marche vers une civilisation fondée sur une base infiniment plus large que celle du passé, et vers un classicisme où se traduiront, pour la première fois, l'influence prépondérante des masses et le rôle primordial du travail".

23 Texto original em francês, tradução livre da autora: "Chacun se rend compte que le travail est la loi humaine et qu'il y a assez d'idéal dans le culte de la beauté et la bienveillance pour rendre la vie splendide". 
seu esquema que apresentava setores residenciais de densidade mais alta. Integradas aos bairros residenciais havia diferentes categorias de escolas, situadas de modo a servirem regiões específicas da cidade, enquanto as instalações para a educação técnica e profissional se situavam entre as áreas residencial e industrial (FRAMPTON, 1997, p.119).

A cidade, embora hipotética, fora pensada como inserida na região de Lyon, no vale do Ródano, concebida como extensão de uma antiga cidade à beira do rio. Tratava-se de uma cidade "média", prevista para aproximadamente 35.000 habitantes ${ }^{24}$, que tinha por principal atividade econômica uma usina metalúrgica à beira do rio. A produção de energia e de água potável para abastecimento da cidade encontrava-se equacionada, garantindo a autonomia da cidade. Tratando-se de uma cidade industrial, sua localização devia ser determinada pela disponibilidade de matéria prima ou de fonte de energia e meios de transporte.

Deve-se salientar que para Garnier a viabilidade de sua cidade dependia da realização de "certos progressos de ordem social" que permitiriam a criação de um conjunto de regulamentos dos aspectos viários, sanitários, etc, disposições que melhor satisfariam as "necessidade materiais e morais do indivíduo" (apud PAWLOWSKI, 1993, p. 40). Assim, destacamos que também na origem do Movimento Moderno a arquitetura e o urbanismo não podiam ser concebidos desvinculados de transformações sociais de outra ordem. Embora na Carta de Atenas essa ideia seja perpetuada, em comparação a Garnier, Le Corbusier posicionou-se de maneira distinta, como poderemos observar adiante. O arquiteto franco-suíço afirmava a condição social de sua época, defendendo que o ordenamento espacial, ou seja, o projeto da cidade e do edifício a partir de uma lógica racional, traria as melhorias necessárias para as condições de vida na sociedade moderna. No Brasil, a contradição que se observa no discurso de Artigas, para nos limitarmos a esse arquiteto, é que este lidava, ao mesmo tempo, com a hipótese de transformações sociais mais amplas que viabilizassem a realização da função social de seus projetos arquitetônicos ou urbanísticos e com a crença de que arquitetura e urbanismo seriam capazes de determinar as transformações das relações sociais $^{25}$ - um misto de reformismo e perspectiva revolucionária.

O projeto da Cité Industrielle apresentava uma estrutura em quadrícula. O complexo industrial situava-se na planície, à beira do rio e o conjunto residencial, num terraço natural. Beneficiando-se de melhores condições de insolação, mais ao alto, estava localizado o conjunto de equipamentos sanitários ${ }^{26}$. Em escala regional, um sistema de tramway garantia o transporte da população.

24 Tony Garnier justificou a sua opção por trabalhar com uma cidade média, o que segundo ele abrangia o caso mais geral no que se refere ao urbanismo. Segundo o autor, isso não poderia ocorrer em uma metrópole ou em uma aldeia. Todavia, uma característica de sua proposta é que a cidade admite o crescimento sucessivo, não sendo, portanto, pensada como um objeto acabado desde sua origem.

25 Otília Arantes chamou a atenção para essa questão, observando que, na “Tábula Rasa” do Movimento Moderno, o argumento básico era que havia "uma possível transformação das relações sociais em função de uma reordenação global do espaço. Chega, por exemplo, a esperar que a nova arquitetura do vidro atente contra a propriedade privada (...)" (ARANTES, 2000, p. 27).

26 Esse conjunto incluída, dentre outros, um hospital, um centro de helioterapia, um asilo, dentre outros. 


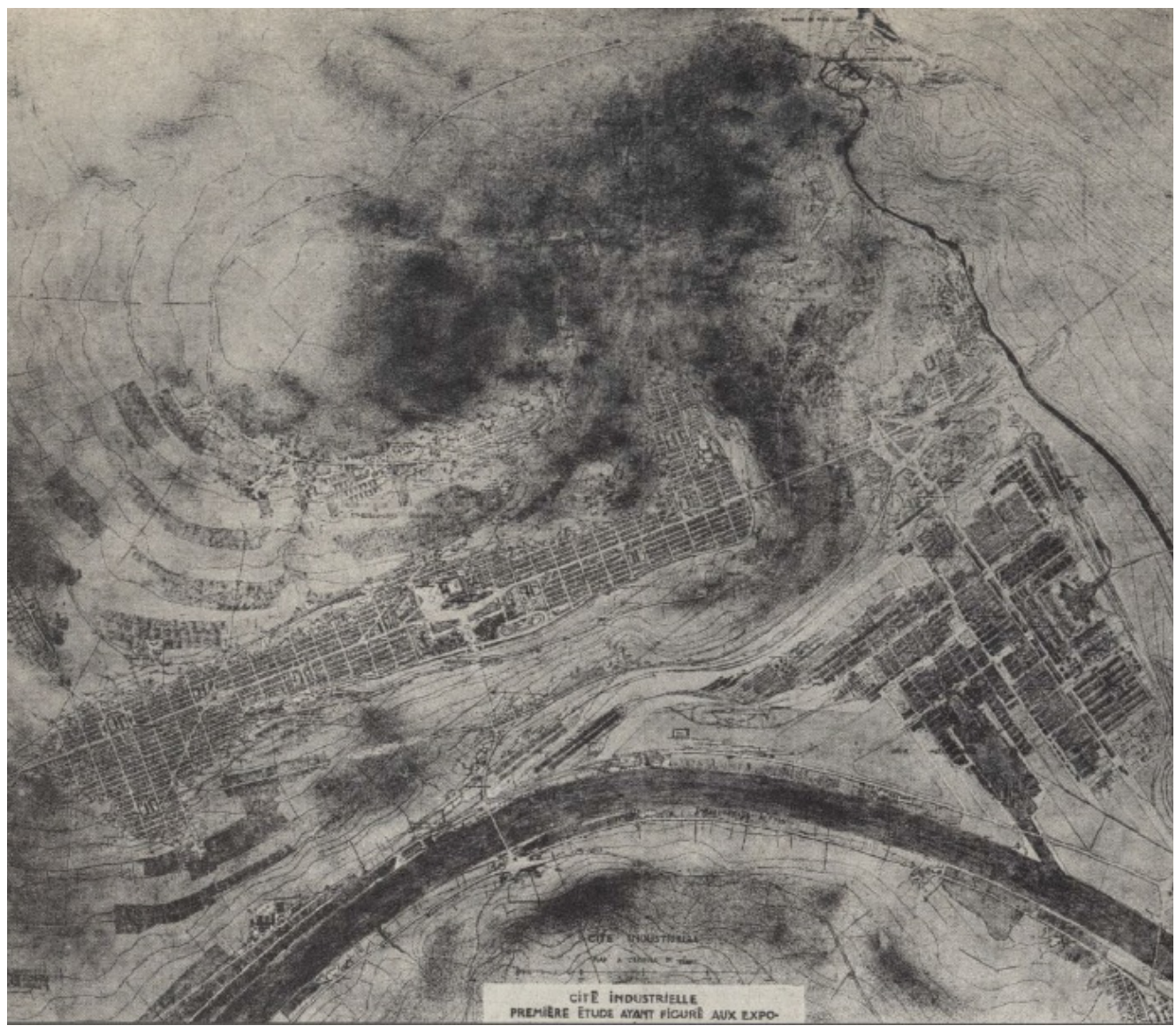

Figura I4 - Tony Garnier. La Cité Industrielle: Zoneamento, 1904.

Os "quartier d habitations" estavam divididos em "ilhotas" de $150 \mathrm{~m}$ x $30 \mathrm{~m}$, subdivididos em lotes de $15 \mathrm{~m}$ x $15 \mathrm{~m}$, sempre tendo uma das faces voltadas para a rua. Composta de pequenas unidades, a cidade compreendia uma rede de ruas paralelas e perpendiculares subordinadas à hierarquia funcional. $\mathrm{O}$ espaço interior das quadras destinava-se aos pedestres. Em outras ruas admitia-se a circulação de veículos e na rua principal, que atravessava o conjunto, passava o tramway (PAWLOWSKI, 1993, p. 46). Havia portanto uma separação da circulação interurbana ("mecânia rápida"), suburbana ("mecânica lenta") e urbana (de pedestres). As escolas foram objeto de especial atenção. As escolas primárias foram localizadas em todos os bairros habitacionais, em meio ao verde que isolava as habitações (idem, p. 51). Já as escolas secundárias e de ensino profissionalizante foram agrupadas em um setor específico.

O centro da cidade concentrava os edifícios públicos, classificados em: I. Serviços administrativos e salas de assembleias, II. Coleções (museus diversos) e III. Estabelecimentos esportivos e de espetáculos. Os grupos II e III localizavam-se em um parque que limitava ao norte a rua principal e o grupo I em um terraço arborizado que permitia a vista da planície, do rio e das montanhas na outra margem. 
Em síntese, os principais aspectos da Cité Industrielle que devemos destacar eram os seguintes:

\section{Aspecto regional do plano}

A Cité Industrielle era pensada como parte de uma região, que deveria compreender outras cidades análogas, em um contexto de descentralização urbana. Ao mesmo tempo, a cidade projetada visava um amplo grau de autonomia, especialmente no que se refere aos equipamento públicos, culturais e de lazer. Pawloswski (1993, p. 63) considerou que esse projeto antecipou a Cidade Satélite que seria concebida dez anos depois nos Estados Unidos, por se tratar de uma cidade média em uma região industrial nas proximidades de uma cidade maior (Lyon).

\section{Propriedade pública da terra}

O projeto da cidade industrial de Garnier pressupunha a "livre disposição do solo pela sociedade", constituindo parte dos "avanços de ordem social" a que o autor se referiu. Disso resultaram determinações como o impedimento do fechamento dos lotes, o que combinado com a restrição da área construída dos lotes residenciais em até $50 \%$ e com a exigência de que o restante da área formasse um jardim público, originava um sistema de circulação de pedestres bastante permeável. Devemos notar que a questão fundiária foi central para boa parte dos arquitetos brasileiros. Na tentativa de construção de uma crítica para explicar os fracassos da arquitetura moderna brasileira no cumprimento de sua função social, muitos levantaram argumentos contra os "interesses" ligados à propriedade privada (especulação, lucro, etc). Por isso o próprio Plano Piloto de Brasília previa a propriedade pública da terra.

\section{Zoneamento}

Autores como Pawlowzski, Frampton e Pevsner avaliaram que a Cité Industrielle foi uma proposta pioneira de urbanismo funcional, em função do zoneamento adotado. Garnier previa a organização de sua cidade em três zonas distintas, de acordo com a função a que se destinavam: trabalho (setor industrial), moradia (setor residencial) e higiene (setor de serviços sanitários). A forma como os setores foram dispostos no terreno visava garantir a autonomia de cada setor, prevendo o isolamento dos três elementos e permitindo sua extensão sem modificar o resto do sistema. (PAWLOWSKI, 1993, p. 46).

Frampton também assinalou o caráter precursor da Cité Industrielle, antecipando, com seu zoneamento, os princípios da Carta de Atenas (FRAMPTON, 1997, p. 119).

\section{Equipamentos públicos, culturais, esportivos}

Garnier previu um programa vultuoso de edifícios sociais e culturais. O arquiteto explicitou no projeto uma valorização dos edifícios públicos, em detrimento das habitações, de caráter mais modesto. Segundo Pawlowski, essa proposta inseria-se em um movimento regionalista, originado no fim do século XIX, que preconizava a autonomia das cidades médias. Para tanto, elas deveriam estar bem equipadas de museus, teatros, bibliotecas e de edifícios administrativos. 
Áreas Verdes

A abundância de áreas verdes é um dos traços característicos do projeto. Pawlowski advertiu que no intuito de chamar a atenção para essa questão, Garnier as inseriu praticamente em todos os lugares. Segundo o autor, o verde abundante era um elemento de integração de grande importância e antecipou a Usine Verte ${ }^{27}$ de Le Corbusier (PAWLOWSKI, 1993, p. 63).

A cidade se conformava como um grande parque ou um grande jardim. Nas zonas residenciais, as áreas não construídas dos lotes originavam jardins públicos que serviam de passagem para os pedestres. O complexo industrial era separado por espaços arborizados. O verde isolava tudo, até dentro do complexo industrial, no interior da usina, criando espaços de repouso e separando as diversas empresas. Os equipamentos esportivos e culturais previstos também foram concebidos em meio ao verde, dentro de parques.

\section{Ventilação e iluminação}

A questão da salubridade era uma tônica da proposta de Garnier. Nesse sentido, a organização dos bairros residenciais tinha por objetivo suprimir corredores estreitos e pátios internos, garantindo a ventilação e a iluminação a partir do exterior. O autor também apresentava a preocupação em garantir janelas de tamanhos adequados voltadas para a fachada sul das residências. No desenvolvimento da arquitetura moderna, esse item (sol e ar puro) se tornou uma das principais premissas de projeto, tendo em Le Corbusier um grande defensor e na Carta de Atenas a consagração de um princípio.

\section{Hierarquização funcional das ruas}

O tramway passava pela rua principal da cidade. Havia ainda uma hierarquização das ruas, com vias de trânsito local e vias de pedestres, constituídas a partir dos espaços não edificados dos lotes residenciais.

\section{Construção em concreto armado}

Todos os edifícios previstos seriam construídos em concreto armado.

Frampton comparou a proposta de Garnier com a Cidade Jardim de Howard, que considerava uma proposta reformista:

Enquanto a Cité de Garnier (...) viria a influenciar os modelos teóricos de planejamento desenvolvidos durante a primeira década da União Soviética, o projeto de Howard levaria à proliferação reformista de comunidades do tipo "cidade-jardim", e, por fim, ao igualmente paradigmático programa New Town, que surgiria na Inglaterra depois da Segunda Guerra Mundial (FRAMPTON, 1997, p. 121).

27 De acordo com o site da Fundação Le Corbusier, "Usine Verte” é uma fábrica em que "o trabalho se realiza verdadeiramente nas condições naturais, tendo-se em conta o lugar, o sol, as perspectivas paisagísticas e de um conjunto de fatores da ordem do sensível" (tradução livre da autora). Disponível em: http://www.fondationlecorbusier.fr/ (acesso em 03/11/2014). 
Pawlowsky também acreditava na superioridade da proposta da Cité Industrielle em relação à Cidade Jardim.

Seu projeto marca uma superioridade muito clara sobre a proposta de Ebenezer Howard. O teórico inglês previa em sua cidade-jardim unicamente indústrias secundárias que não poderiam, portanto, garantir sua autonomia. Em Garnier, em contrapartida, a indústria pesada é considerada como animadora da cidade ${ }^{28}$ (PAWLOWSKI, 1993, p. 63).

\subsubsection{Le Corbusier}

O trabalho de Garnier despertou o interesse de Le Corbusier desde a primeira década do século XX, pouco depois da apresentação da Cité Industrielle de 1904. Em 1919, portanto após a publicação de 1917, Le Corbusier escreveu a Tony Garnier:

Eu desejo demonstrar minha profunda admiração. Com seu livro, você faz o único material possível de nossa época (...). Você fez a síntese e o que há de belo em seu trabalho é que você exprimiu o verdadeiro espírito de nossa época ${ }^{29}$ (apud VIDLER, 1990, p. 71).

Em 1920, o arquiteto franco-suíço também publicou na revista l’Esprit Nouveau um artigo sobre a obra de Garnier, afirmando:

Reservando todo julgamento sobre a coordenação das zonas dessa Cité Industrielle, sofremos todas as consequências benéficas da ordem: onde a ordem reina, nasce o bem-estar. Pela feliz criação de um sistema de loteamentos, os bairros residenciais, mesmo operários, assumem alta significação arquitetôni$\mathrm{ca}^{30}$. (idem, ibidem)

28 Texto original em francês, tradução livre da autora: Son projet marque une suppériorité très nette sur celui d'Ebenezer Howard. Le théoricien anglais prévoyait dans sa Cité-Jardin uniquement des industries secondaires que ne pouvaient donc pas assurer leur autonomie. Chez Garnier, en revanche, l'industrie lourde est considérée comme animatrice de la cité.

29 Texto original em francês, tradução livre da autora: je tiens à vous dire ma profonde admiration (...). Avec votre livre, vous en faites le seul matériau possible de notre époque (...), vous avez fait la synthèse et ce qu'il $y$ a de si beau dans ce que vous avez fait, c'est que vous avez exprimé le premier véritable esprit de notre époque.

30 Texto original em francês, tradução livre da autora: Réservant tout jugement sur la coordination des zones de cette Cité Industrielle, on subit les conséquences bienfaisantes de l'ordre: où l'ordre reigne, naît le bien-être. Par la création heureuse d'un système de lotissement, les quartiers d habitations, même ouvrières, prennent haute signification architecturale. 
A principal crítica de Le Corbusier ao projeto de Garnier foi a baixa densidade prevista no centro da cidade, algo que iria "corrigir" nas suas propostas urbanísticas. Pawlowski (1993, p. 146) identificou que Tony Garnier deixou um legado para o jovem arquiteto e para a arquitetura moderna, destacando o tratamento do terreno da cidade como um grande parque, onde o tráfego de pedestres era independente da rede de ruas e do tráfego de veículos, assim como a orientação adequada dos edifícios como elemento essencial do planejamento. Testemunho disso, ainda segundo o autor, foi o fato de as atividades dos três primeiros CIAMs terem constituído um desenvolvimento das ideias de Garnier. Segundo o autor, se a noção de higiene fosse ampliada para incluir a de lazer, "observarmos que esse projeto aprofundou as discussões dos problemas de circulação, a Cité Industrielle praticamente deu conta avant la lettre dos princípios que foram tratados mais tardes pela carta dos CIAM"31. Pawlowski também considerou a proposta de caráter precursor por destinar um lugar considerável à administração da cidade, com a valorização do "centro cívico".

Em "Maneira de Pensar o Urbanismo"32, Le Corbusier teceu elogios a Tony Garnier, que em sua obra $L a$ cité industrielle, propôs, "pela primeira vez, um solo da cidade tornado domínio público(...) [prestando-se] à instalação de dispositivos comunitários caros a todos os habitantes (...) [e integrando] a dignidade e a pureza (...) nos locais de habitação, de trabalho e de convívio cívico" (LE CORBUSIER, 1977, p. 40).

Em "Urbanismo", de 1925, Le Corbusier apresentou as propostas para a "Cidade Contemporânea de três milhões de habitantes", hipotética, e o "Plano Voisin de Paris", para o centro da capital francesa, desenvolvido sob o patrocínio da empresa Aéroplanes $G$. Voisin $^{33}$. Diferentemente da cidade imaginária de Garnier, a cidade contemporânea de Le Corbusier foi desenhada sobre um terreno plano e abstrato, situação que ele considerava "ideal". Ele afirmou:

Procedendo à maneira do prático em seu laboratório, fugi dos casos específicos: afastei todos os acidentes; concedi-me um terreno ideal. O objetivo não era vencer o estado das coisas preexistentes, e sim conseguir, ao construir um edifício

31 Garnier esteve presente no $1^{\circ}$ CIAM, em 1928.

32 O título original da publicação é "Manière de Penser l'Urbanisme". Na edição portuguesa, a tradução manteve o sentido do título inalterado ("Maneira de Pensar o Urbanismo"). Todavia, no Brasil, o livro teve o título traduzido como "Planejamento Urbano". No desenvolvimento desta pesquisa, foi consultada ora a versão portuguesa, ora a brasileira. Assim, apesar da distinção, trata-se da mesma obra. Meyer já chamou a atenção para a questão: "A estratégia comercial é evidente; "planejamento urbano, naquele momento, mobilizava mais interessados. A sensibilidade comercial da editora e dos responsáveis pela tradução (...) nos fornece preciosa informação: "planejamento urbano" é moderno, prestigioso e vendável, enquanto "urbanismo" soa legendário, um pouco arcaico e esgotado. (...) Fica evidente que a exacerbação das dificuldades e dos compromissos daquele momento havia carregado o urbanismo para uma atuação de tipo tecnocrático. É o apogeu das análises científicas com seus sistemas, matrizes e modelos" (MEYER, 1990, p.13).

33 O arquiteto afirmou que, considerando que "o automóvel abalou as bases seculares do urbanismo", propôs a diversos fabricantes de automóveis o patrocínio para a construção do "Pavilhão do Espírito Novo na Exposição Internacional de Artes Decorativas”, dedicado à habitação e ao urbanismo. (LE CORBUSIER, 2000, p. 261). 
teórico rigoroso, formular os princípios fundamentais do urbanismo moderno (LE CORBUSIER, 2000, p.156, grifo do autor).

Colquhoun considerou que cidade de Le Corbusier

(...) é qualquer coisa, menos um modelo no sentido científico. É uma imagem concreta, integralmente trabalhada em seus detalhes. Portanto, somos forçados a questionar o status dos princípios gerais que a cidade ilustra. Seria ela científica, neutra e refutável ou artística, ideológica e irrefutável. Tudo aponta para a segunda interpretação. Caso fosse necessária qualquer outra prova, porém, talvez observássemos como o conceito de cidade de Le Corbusier é fortemente fundamentado na tradição do século XVIII (COLQUHOUN, 2004, p. 114).

Contrastando com a proposta de seu antecessor, que previa a sua cidade expandindo-se de outra pré-existente, a de Le Corbusier era abstrata e sem relações com o entorno ${ }^{34}$. Também contrastava com a Cité Industrielle no que se refere à escala, propondo uma metrópole de três milhões de habitantes. "Corrigindo" aquilo que lhe parecia a principal falha da proposta de Garnier, Le Corbusier propôs um grande adensamento para a região central.

De modo geral, a cidade proposta organizava-se da seguinte maneira: o centro, área de negócios, contando também com residências; uma zona fabril na periferia e, também periféricas, cidades-jardins, que abrigavam as moradias dos trabalhadores das fábricas e do centro de negócios da cidade. Le Corbusier propôs uma grande estação intermodal no centro, concentrando ônibus, metrô e avião em um único edifício. Os princípios fundamentais enunciados no Plano eram: o descongestionamento do centro das cidades, aumento da densidade, aumento dos meios de circulação e aumento das superfícies arborizadas (LE CORBUSIER, 2000, p. 161).

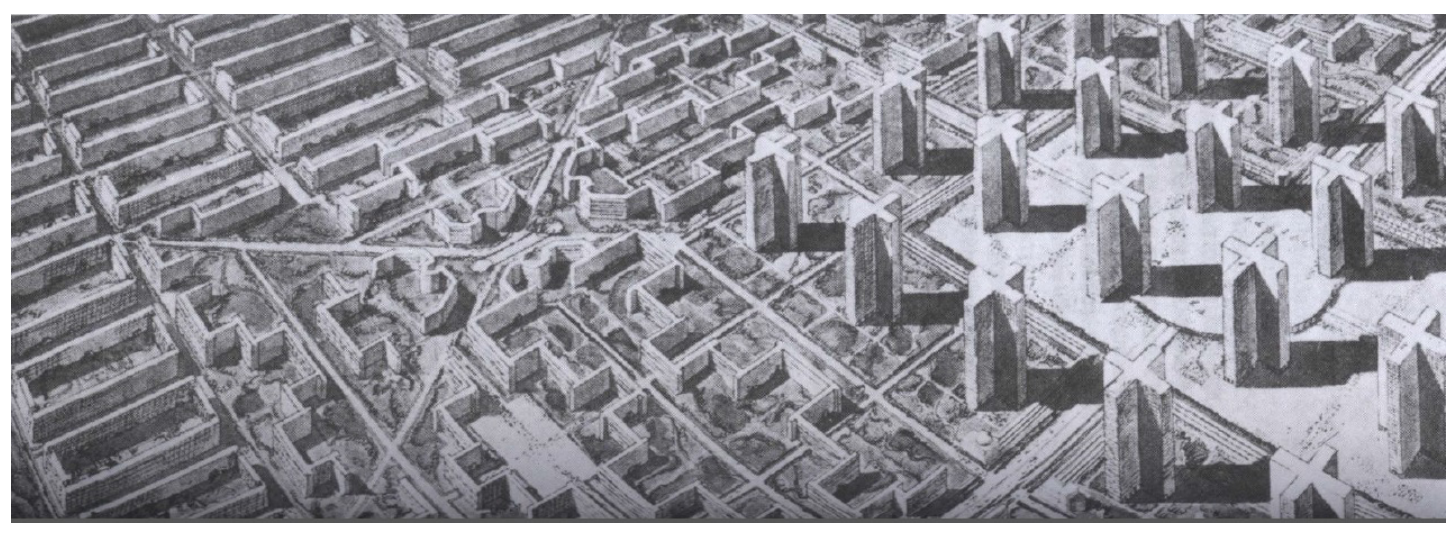

Figura I5 - Le Corbusier. Une Ville Contemporaine, 1922.

34 Colquhoun afirmou que "Le Corbusier, mais do que qualquer outro arquiteto do movimento moderno, insistia que a arquitetura era produto da inteligência criativa individual. A ordem que ela criava era ideal, e não pragmática (COLQUHOUN, 2004, p. 159). 
O Plano Voisin foi uma proposta de Le Corbusier para o centro de Paris, aplicando na capital francesa os princípios que desenvolvera em sua "cidade ideal". Tal plano incluía uma "cidade de negócios" (a área compreendia o polígono da Praça da République à rua do Louvre e da estação do Leste à rua de Rivoli) e uma "cidade de residência (da rue des Pyramides à praça giratória dos Champs Elysées e da estação Saint Lazare à rue de Rivoli), demolindo bairros "supersaturados e repletos de habitações burguesas que abrigam escritórios". Coerente com a sua defesa de intervenções "cirúrgicas", o arquiteto propunha a completa demolição e reconstrução do perímetro de intervenção. Para isso, era necessário desapropriar 240 ha em uma área que ele identificou como "insalubre" para a construção do "Centro de Negócios". O convencimento da viabilidade de sua proposta baseava-se na imensa valorização da área que o projeto proporcionaria, especialmente devido ao adensamento e à qualidade da proposta. $\mathrm{O}$ arquiteto defendia:

Esse plano combate os bairros mais infectos, as ruas mais acanhadas; não procura "oportunizar", ceder aqui e ali um centímetro de terreno sob o ímpeto das artérias congestionadas. Não. Ele abre no ponto estratégico de Paris uma esplêndida malha de comunicaşão (....), ele estabelece um quadriculado de grandes artérias de 50, 80 e 120 metros de largura que se cruzam a todos os 350 ou 400 metros e, ao erguer arranha-céus de planta cruciforme no centro dos vastos quarteirões assim criados, cria uma cidade vertical, uma cidade que recolheu suas células esmagadas no solo e as dispôs longe do solo, no ar e na luz.

(...) A densidade demasiado grande dos antigos bairros sacrificados pelo "Plano Voisin" não é diminuída. É quadruplicada.

(...) é o ritmo majestoso das superfícies verticais que se prolongam ao longe pelo efeito da perspectiva e determinam volumes puros. Entre um e outro desses arranha-céus de vidro, estabelecem-se relações de cheios e vazios. A seus pés, desenham-se praças. A cidade recobra eixos como em todas as obras da arquitetura. O urbanismo entra na arquitetura, a arquitetura entra no urbanismo. (LE CORBUSIER, 2000, p. 264-265, grifos do autor)

A descrição de le Corbusier dá uma medida do que deveria ser o urbanismo, em seu ponto de vista. Para ele, conforme procuramos evidenciar, consistia, sobretudo, numa atividade de prancheta, trabalhada na escala da cidade e não de um lote. Assim, privilegiou os aspectos de circulação, defendeu o adensamento através da verticalização, que permitia, ao mesmo tempo a liberação do solo para a criação de parques e áreas verdes. Diferentemente de Garnier, embora Le Corbusier também tenha privilegiado o trabalho, o fez em termos de eficiência, remetendo ao taylorismo ao invés do socialismo utópico. A melhoria na qualidade de vida dos trabalhadores era uma decorrência do aumento da eficiência. Por isso devia ser superado o problema do congestionamento, deviam ser ampliados os espaços adequados para abrigar os negócios em Paris, as superfícies verdes, etc.

A Carta de Atenas, documento que sistematizou as discussões do IV CIAM, de 1933, se tornou a referência entre os arquitetos modernos sobre as questões de urbanismo e planejamento urbano. Naquele ano, a bordo do navio "Patris II" os arquitetos ligados ao 
CIAM reuniram-se para discutir a cidade funcional. Foram analisadas trinta e três cidades com base em uma cartografia uniformizada, visando facilitar as comparações. Na avaliação de Scherer, embora o congresso tenha sido concluído sem a formulação de

(...) propostas de ação comum ou modelos urbanísticos concretos, ficou patente que as mudanças necessárias ao urbanismo contemporâneo implicavam uma opção política diferenciada e não apenas a melhoria técncia das práticas profissionais existentes" (in LE CORBUSIER, 1993, s/n).

Houve versões distintas desta carta: uma consta nos anais do evento, outra foi redigida por Le Corbusier, há uma versão publicada no livro de Joseph Luis Sert “Can our cities survive” e, por fim, há uma versão em holandês que confronta a versão de Le Corbusier com aquela dos anais. Nesta dissertação, analisamos o documento produzido por Le Corbusier, publicado originalmente em 1943.

De forma geral, a Carta de Atenas afirmava os princípios do urbanismo funcionalista, a partir de ideias que vinham sendo construídas ao longo do século XX, dos quais Le Corbusier foi um grande difusor. Como assinalou Scherer na apresentação da publicação brasileira, os princípios estabelecidos eram a obrigatoriedade do planejamento regional e intra-urbano, a submissão da propriedade privada do solo aos interesses coletivos, a industrialização dos componentes e a padronização das construções, a limitação do tamanho e da densidade das cidades, a edificação concentrada, porém adequadamente relacionada com amplas áreas de vegetação. Tal urbanismo supunha ainda o uso intensivo da técnica moderna na organização das cidades, o zoneamento funcional, a separação da circulação de veículos e pedestres, a eliminação da rua corredor e uma estética geometrizante (LE CORBUSIER, 1993, s/n).

A seguir, enunciamos os pontos principais do urbanismo funcional, baseados na análise do plano de Le Corbusier para a Cidade Contemporânea de três milhões de habitantes, do Plano Voisin e de sua própria versão da Carta de Atenas.

\section{A região como unidade de planejamento}

O primeiro princípio assinalado na Carta de Atenas foi, mais uma vez, a defesa da região como unidade básica de análise: "a cidade é só uma parte de um conjunto econômico, social e político que constitui a região” (item 1 da Carta de Atenas). Como podemos perceber, o planejamento regional foi uma premissa que ocupou os pensadores do urbanismo durante todo o século XX. Isso foi desenvolvido tanto no âmbito do movimento moderno em arquitetura, que influenciou os arquitetos paulistas, quanto do regional planning que consistiu na principal referência para o urbanismo de Anhaia Mello. Nessa ideia, reconhecemos uma origem comum a ambas vertentes, que remonta à teoria do escocês Patrick Geddes (18541932) apresentada em sua obra “Cidades em Evolução", de 1915.

Em suas propostas urbanísticas dos anos 1920, Le Corbusier já defendia que a cidade devia ser estudada no conjunto de sua região de influência. Um plano de região devia substituir o "simples plano municipal”. O limite da aglomeração devia ser função do raio de sua ação econômica. Segundo o arquiteto "esse [era] o urbanismo total, capaz de levar o equilíbrio à província e ao país" (LE CORBUSIER, 1993, s/n) 


\section{Padronização, modulação e industrialização}

Le Corbusier defendia a padronização e a industrialização dos processos de construção, visando equiparar a eficiência do trabalho da mão-de-obra da construção à da máquina. $\mathrm{O}$ autor chegou mesmo a propor que se empregasse os métodos tayloristas no canteiro de obra: "a mão-de-obra, com o taylorismo, será classificada: a cada qual, segundo seus méritos, a recompensa dos trabalhos prestados" (LE CORBUSIER, 2000, p. 165). A cidade contemporânea de Le Corbusier era modulada. Um módulo "vasto", de 400 m constituía a base do projeto.

\section{Áreas verdes}

Le Corbusier defendeu o reconhecimento por meio legal da presença de uma zona não edificável entre a cidade e a cidade-jardim, que compunha o "cinturão verde da cidade". Essa zona, de proteção e extensão, seria constituída por bosques e prados, atuando como "reservas de ar" (LE CORBUSIER, 2000, p. 157). O autor ampliou a proposta de Garnier em defesa do verde e da arborização, a que se referia como "pulmão" da cidade. Sua proposta combinava um aumento da densidade, principalmente no centro, por meio da verticalização ${ }^{35}$, com o aumento significativo das superfícies arborizadas. Os apartamentos poderiam assim ser contruídos longe das ruas, em meio a "parques extensos", prevendo-se, inclusive, loteamentos fechados. Assim ele descreveu como deveria ser o entorno dos arranha-céus no centro da cidade:

Ao pé dos arranha-céus e em toda a volta, local de $2.400 \times 1.500 \mathrm{~m}\left(3.640 .000 \mathrm{~m}^{2}\right)$ coberto de jardins, parques e quincunces. Nos parques, ao pé e à volta do arranha céus, os restaurantes, cafés, comércios de luxo, construcões com dois ou três terraços em degraus; os teatros, salas, etc. (...). À esquerda: os grandes edifícios públicos, museus, prefeitura, serviços públicos. Mais longe à esquerda, o jardim inglês. (o jardim inglês é destinado à extensão lógica do centro da cidade) (LE CORBUSIER, 2000, p. 161).

\section{Hierarquização do tráfego}

É conhecida a posição de Le Corbusier acerca da rua tradicional, à qual se referia como "rua corredor". Como contra-proposta, defendia a hierarquização do trânsito em níveis diferentes, separando os veículos de carga (subsolo); veículos de "passeadores" (pequenas corridas em todos os sentidos, no nível térreo dos imóveis); e veículos rápidos, que ocupavam as vias de travessia para circulação rápida em mão única, em vastas passarelas, nos sentidos norte-sul e leste-oeste. O arquiteto defendia a diminuição do número de cruzamentos, visando a redução de acidentes de trânsito. Esse mesmo argumento foi retomado por Anhaia Mello para defender as unidades de vizinhança organizadas em superquadra (CPEU, 1963a, p. 32).

35 Em sua cidade contemporânea, Le Corbusier previa que o centro de negócios fosse ocupado por arranha-céus, chegando a uma densidade de 3.000 habitantes/ha, mantendo-se $95 \%$ da superfície arborizada. Nas zonas residenciais, previa o que chamou de "loteamento com reentrâncias" ("residência luxuosa"), com densidade de 300 hab/ha e $85 \%$ da superfície arborizada e "loteamentos fechados", com 305 hab/ha e $48 \%$ da superfície arborizada. De certa forma, em sua proposta a proporção de "verde" ia de acordo com a luxuosidade da população ocupante. 


\section{Zoneamento Funcional}

Embora na "Carta de Atenas" a caracterização das funções da vida do homem a partir da qual deve ser organizada a cidade esteja mais bem desenvolvida, nos anos 1920, Le Corbusier já as levava em consideração para os seus estudos sobre o urbanismo. Assim, em "O urbanismo", um espaço destacado foi dado às questões da circulação, que devia ser hierarquizada e funcional, do trabalho e do repouso. Devemos ressaltar sua insistência em abarcar todos os aspectos da vida através da arquitetura e do urbanismo, como se observa na passagem a seguir, que trata do "repouso":

Que fazer das horas livres, dessas horas vazias? Preenchê-las. É mais do que evidente que se trata aqui de um problema de arquitetura: a habitação; de urbanismo: a organização dos bairros residenciais, a máquina de espairecer. (LE CORBUSIER, 2000, p. 187).

Na Carta de Atenas, Le Corbusier descreveu as quatro funções - habitar, trabalhar, recrear-se e circular como "as chaves do urbanismo". A cada qual correspondia um setor autônomo na cidade, a ser estruturado e localizado em função de um plano. "Nessa distribuição, serão consideradas as necessidades vitais do indivíduo e não o interesse ou o lucro de um grupo particular. O urbanismo deve assegurar a liberdade individual e, ao mesmo tempo, favorecer e se apropriar dos benefícios da ação coletiva” (item 78 da Carta de Atenas). O urbanismo aparecia de forma autoritária, ao pretender regulamentar todo o "ciclo das funções cotidianas", visando "a mais rigorosa economia de tempo". Nesse contexto, a habitação era a função mais relevante e "o ponto de união de todas as medidas".

Segundo a Carta de Atenas, a cidade era "definida como uma unidade funcional, [devendo] crescer harmoniosamente em cada uma de suas partes" (item 84 da Carta de Atenas). Isse seria alcançado pois a cidade adquiriria:

(...) o caráter de uma empresa estudada de antemão e submetida a um plano geral. Sábias previsões terão esboçado seu futuro, descrito seu caráter, previsto a amplitude do seu desenvolvimento e limitado previamente seu excesso. Subordinada às necessidades da região, destinada a enquadrar as quatro funções-chave, a cidade não será mais o resultado desordenado de iniciativas acidentais (idem, grifos nossos).

Na passagem acima, é importante destacar a confiança no plano como instrumento de previsão que garantiria o controle do crescimento urbano conforme parâmetros estabelecidos. Também está presente o conceito de região, unidade a partir da qual se devia analisar e projetar a cidade: “Cada caso será inscrito no plano regional; os terrenos serão medidos e atribuídos a diversas atividades; claro ordenamento no empreendimento que será iniciado a partir de amanhã (...)" (item 85 da Carta de Atenas). Le Corbusier defendia ainda a fixação por meio de lei do "estatuto do solo", que tinha por função "dotar cada função-chave dos meios de melhor se exprimir, de se instalar nos terrenos mais favoráveis e a distâncias mais proveitosas". Essa lei iria favorecer "todas as iniciativas adequadamente planejadas, [velando] para que elas se insiram no plano geral e sejam sempre subordinadas aos interesses 
coletivos que constituem o bem público". O arquiteto enfatizou:

\begin{abstract}
O solo - território do país - deve tornar-se disponivel a qualquer momento, e por seu justo valor, avaliado antes do estudo dos projetos. O solo deve ser mobilizável quando se trata do interesse geral (...) Por ignorar certas regras, o campo se esvaziou, as cidades se encheram para além de qualquer limite razoável, as concentrações industriais se fizeram ao acaso, as moradias operárias se tornaram cortiços (LE CORBUSIER, 1993, s/n).
\end{abstract}

\title{
Habitar
}

A habitação era tida como a questão fundamental do urbanismo funcionalista. A lógica de ordenamento a que o arquiteto urbanista devia proceder partia da célula habitacional (a "célula social"), ampliando-se para sua inserção em um grupo formando uma unidade habitacional de proporções adequadas (item 88 da Carta de Atenas). A partir da célula, da unidade-moradia é que se estabeleceriam no espaço urbano as relações entre todas as funções urbanas.

$\mathrm{Na}$ Carta de Atenas, Le Corbusier denunciou os males da cidade industrial, atacando em especial a má condição das moradias, dispostas em zonas inadequadas, incapazes de satistazer as necessidades mínimas de "sol, vegetação e espaço" nessecárias à população. $\mathrm{O}$ arquiteto propunha dispor os bairros habitacionais em áreas bem localizadas, observando-se as condições topográficas e climáticas, e atendendo aos requisitos de insolação e de superfícies verdes adequadas.

A higiene era a questão que norteava a localização dos setores habitacionais e a saúde pública sobrepunha-se a qualquer outro parâmetro. Curiosamente, o autor não falou em saneamento básico, restringindo-se aos fatores de insolação e de áreas verdes. Ao tratar da "higiene" na escala urbana, afirmou:

Não basta sanear a moradia, mas é preciso ainda criar e administrar seus prolongamentos exteriores, locais de educa̧̧ão física e espaços diversos para esporte, inserindo, antecipadamente, no plano geral, as áreas que thes serão reservadas (item 24 da Carta de Atenas) ${ }^{36}$.

As formas possíveis de moradia eram: casa individual da cidade-jardim, casa individual acoplada a uma pequena exploração rural e imóvel coletivo provido de todos os serviços necessários ao bem estar de seus ocupantes (item 47 da Carta de Atenas). Nessas condições,

(...) a moradia inserida desde então em pleno campo, estará completamente protegida dos ruídos e das poeiras, mantendo-se a uma proximidade que suprimirá os longos trajetos diários; ela voltará a ser um organismo familiar normal. As 'condições naturais' assim reencontradas contribuirão para fazer cessar o nomadismo das populações operárias.

36 Entre os anos 1920 e 1930, o esporte despontou como lazer das massas. Foi bastante incentivado nos regimes fascista e nazista, como meio de se alcançar a "raça ariana". 
Acerca da correspondência entre a "célula" arquitetônica e o planejamento urbano, Colquhoun posicionou-se da seguinte forma:

\begin{abstract}
Apesar da recusa de Le Corbusier em estabelecer qualquer distinção entre a arquitetura e o planejamento urbano ser teoricamente correta, a diferença em sua aplicação da teoria a cada campo é tão grande que parece legítimo voltar à distinção convencional ao considerar a relação de sua teoria com sua prática. Quando Le Corbusier aplica sua teoria à cidade, ele simplesmente volta à não resolvida entre o engenheiro e o arquiteto. $O$ arquiteto ressurge em seu papel puramente ideológico (COLQUHOUN, 2004, p. 111-113).
\end{abstract}

\title{
Recrear-se
}

Na Carta de Atenas, Le Corbusier tratou, sobretudo, das áreas livres, superfícies arborizadas e equipamentos esportivos. De modo geral, as áreas eram insuficientes, mal localizadas ou inadequadas. As propostas contra esses males compreendiam garantir nos bairros habitacionais a superfície verde necessária à organização de jogos e esportes para todas as idades, demolição de bairros considerados "insalubres" a serem substituídos por superfícies verdes, construir equipamentos escolares e de uso comunitário.

Em São Paulo, Anhaia Mello também dedicou sua atenção à vinculação das áreas verdes ao lazer da população. Seu enfoque era o "recreio ativo e organizado" do trabalhador e sua proposta a de fazer um sistema de espaços verdes equipados com playgrounds e outros equipamentos de lazer nos bairros industriais, que trariam provisoriamente "o campo para a cidade" e que seriam capazes de melhorar os hábitos e a moral da população dessas áreas (TIMÓTEO, 2011, p. 11)

\section{Trabalhar}

A questão primordial relativa ao trabalho consistia nos deslocamentos longos e cansativos a serem realizados entre o local de moradia e de trabalho, associada à ineficiência dos sistemas de transporte. Outra aspecto importante referia-se à localização das indústrias, que não obedecia critérios ou regras mas se dava de forma descontrolada, obedecendo à lógica da especulação imobiliária. As propostas apresentadas eram planejar adequadamente os locais de trabalho em relação aos de moradia, visando reduzir as distâncias percorridas ao mínimo necessário. Ao invés dos anéis periféricos à cidade, Le Corbusier propunha na Carta de Atenas uma organização linear dessas áreas, ao longo de locais de passagem, contíguas a estradas de ferro, canais fluviais e rodovias. A separação entre as zonas de habitação e de trabalho era feita por uma zona de vegetação.

\section{Circular}

$\mathrm{Na}$ Carta de Atenas, Le Corbusier reforçou a proposta que vinha defendendo desde os anos 1920, de hierarquização de tráfego em diferentes níveis, distanciamento das ruas em relação aos edifícios, etc. Novamente, os leitos de grande circulação deveriam ser isolados por zonas de vegetação.

O "programa" da cidade devia, de acordo com a Carta de Atenas,

(...) ser elaborado com base em análises rigorosas, feitas por especialistas. Ele deve [devia] prever as etapas no tempo e no espaço. Deve [deveria] reunir em 
um acordo fecundo os recursos naturais do sítio, a topografia do conjunto, os dados econômicos, as necessidades sociológicas, os valores espirituais.

Para isso, recorria-se a uma visão "biologista" em que cada "órgão claramente definido” desempenharia com perfeição suas funções essenciais.

Nos documentos que acabamos de analisar encontram-se elementos-chave do urbanismo moderno, como a funcionalidade urbana, o zoneamento funcional; o estatuto do solo e da propriedade; a relação entre arquitetura e Estado; o plano como instrumento de ordenamento urbano, inserido no contexto regional; e o arquiteto como profissional indicado para exercer o urbanismo funcional. Discorremos sobre dois deles, "o papel do arquiteto" e "o Estado como cliente", importantes para compreender o posicionamento dos arquitetos paulistas no debate sobre urbanismo a partir dos anos 1940.

\section{O papel do Arquiteto}

Le Corbusier foi dos primeiros a defender o urbanismo como atribuição dos arquitetos:

O urbanista não se distingue do arquitecto. O primeiro organiza espaços arquitetônicos, fixa o lugar e o destino dos volumes de construção, liga todas as coisas no tempo e no espaço por uma rede de circulação. O outro, o arquitecto, ocupando-se, por exemplo, duma simples cozinha, também projecta volumes construtivos, cria espaços, decide a respeito de circulações. Na fase do acto criador, o arquitecto e o urbanista são um só (LE CORBUSIER, 1977, p. 13-4).

Na Carta de Atenas, consta que "a arquitetura preside os destinos da cidade". Algumas conceituações do urbanismo formuladas por Le Corbusier aproximaram as duas profissões. Dentre elas, o trabalho na escala humana, a "célula habitacional" como ponto de partida e a definição de urbanismo como "ciência de três dimensões e não apenas duas". Tanto arquitetura quanto urbanismo estavam submetidos aos três parâmetros do desenho definidos pelo arquiteto - volume, superfície, planta (COLQUHOUN, 2004, p. 164). Sujeitos às mesmas regras, arquitetura e urbanismo foram encerrados em um mesmo campo.

A arquitetura é responsável pelo bem-estar e pela beleza da cidade. É ela que se encarrega de sua criação ou de sua melhoria, é ela que está incumbida da escolha e da distribuição dos diferentes elementos cuja proporção feliz constituirá uma obra harmoniosa e duradoura. A arquitetura é a chave de tudo (Carta de Atenas, item 92).

Observe-se que a justificativa do urbanismo como atribuição de arquitetos apoiava-se nos valores arquitetônicos definidos por Vitrúvius: a "função" [utilitas], a "durabilidade" [firmitas] e a "harmonia" [venustas]. Não apenas o profissional devia ser "completo", como descrito em De architectura, mas também a obra devia ser uma totalidade. 
Tal concepção de urbanismo inseria-se na perspectiva do ordenamento urbano, a partir do projeto e do desenho, instrumento de trabalho do arquiteto. Le Corbusier afirmava: "Entedio-me infinitamente em descrever (...) essa futura terra de delícias (...). Em contrapartida, como é apaixonante, antes de escrever, organizar esse mundo iminente na prancheta de desenho (...)" (LE CORBUSIER, 2000, p. 182).

O ordenamento espacial era a resposta aos problemas sociais, chegando-se à defesa irrestrita da geometria como princípio racional de planejamento urbano: "A cidade atual está morrendo por não ser geométrica. Construir ao ar livre é substituir o terreno irregular, insensato, que é o único existente hoje, por um terreno regular. Fora disso não há salvação" (idem, p. 164, grifos do autor). O resultado era o controle completo da vida social. O plano era o instrumento pelo qual os arquitetos iriam projetar suas cidades: "Nossa tarefa atual é arrancá-las [as cidades] de sua desordem por meio de planos nos quais será previsto o escalonamento dos empreendimentos ao longo do tempo" (Carta de Atenas, item 23, grifo nosso). Note-se que o plano aparecia como instrumento de ordenamento das cidades.

Por outro lado, Le Corbusier dedicou-se a situar a profissão do arquiteto em relação à engenharia. Como afirmamos anteriormente, Colquhoun considerava a teoria da arquitetura apresentada por Le Corbusier na década de 1920 como uma tentativa de fundir dois pontos de vista contraditórios - um proveniente da tradição do pensamento clássico do século XVII, segundo o qual o valor arquitetônico repousava sobre princípios eternos e na lei natural, e outro proveniente do historicismo idealista alemão, que relacionava o valor arquitetônico com sua posição na história, independente de qualquer princípio estabelecido a priori. Neste sentido, o autor identificou um conflito irresoluto entre esses dois pontos de vista, em que arquiteto e engenheiro "aparecem como protagonistas que desempenham vários papéis” (COLQUHOUN, 2004, p.163). Segundo o autor,

Apesar de as obras do engenheiro serem necessárias para refletir a subjacente ordem matemática do universo, o engenheiro também é visto como um representante das forças cegas da história e como alguém que trabalha em busca da solução de problemas práticos. Suas obras constituem a mais alta realização coletiva da humanidade e tendem à organização racional da sociedade. Por outro lado, é precisamente o fato de o engenheiro não estar conscientemente preocupado com valores e de não possuir ideologia que o impossibilita de substituir o artista-arquiteto, cuja tarefa é satisfazer uma demanda por imagens do ideal. É assim que Le Corbusier justifica o papel do artista-arquiteto em uma sociedade industrial e determina o trabalho do arquiteto como simultaneamente uma obra de tecnologia e uma obra de arte. Apesar de o arquiteto e o engenheiro empregarem diferentes meios e terem diferentes intenções, ambos trabalham a favor da mesma finalidade histórica. Portanto, encontramos em Le Corbusier uma dupla afirmação. De um lado, ele invoca o destino histórico e exige um comprometimento total com a tecnologia e, em última análise, com o estado tecnocrático. De outro, mantém-se fiel à ideia do arquiteto como sujeito criativo que transforma tecnologia em arte, produção material em ideologia (COLQUHOUN, 2004, p. 163). 
Colquhoun observou ainda que a dicotomia entre arquitetura e engenharia era sintomática de uma tendência dialética que permeava toda a teoria e prática de Le Corbusier, marcadas por oposições como ordem/desordem; harmonia platônica/ contingência; mente/ organismo; forma/ estrutura; simetria/ assimetria. Essa dialética, ainda que adquirisse uma "nova urgência pela necessidade de assimilar o espírito do idealismo historicista e acomodar forças conturbadoras da tecnologia, [pertencia] à tradição do século XVIII" (idem, p. 164).

\section{O Estado como Cliente}

Desde que, em 1927, seu projeto para o Palácio das Nações fora rejeitado em nome de uma proposta academicista e, principalmente, desde o $1^{\circ}$ CIAM, em 1928, Le Corbusier liderou a vertente latina do movimento moderno em arquitetura (BARONE, 2000, p. 29). Essa vertente reivindicava melhores relações com os Estados em seus países, defendendo a adoção dos princípios da arquitetura moderna. Na Carta de Atenas, reiterou-se a importância de os órgãos administrativos contarem com o saber dos "técnicos qualificados" para o enfrentamento do "estado caótico" das cidades. Tratava-se de esclarecer as autoridades, frequentemente hostis aos princípios do urbanismo moderno, subsidiando sua ação.

(...) é preciso fazer com que sejam admitidos pelos órgãos administrativos encarregados de velar pelo destino da cidade e que não raro são hostis às grandes transformações propostas por esses dados novos [os princípios do urbanismo moderno]. É necessário portanto que a autoridade seja esclarecida e, depois, que ela aja. Clarividência e energia podem vir a restaurar a situação comprometida (item 74 da Carta de Atenas).

Para Le Corbusier, o Estado era o patrocinador ideal de seus projetos, por ser suposamente neutro e voltado para a consecução do bem comum (LE CORBUSIER, 1993, s/n). Com uma proposição reformista, Le Corbusier defendia que "o Estatuto do Solo e um plano que não deixe nada ao acaso são os intrumentos dos quais se deve valer o poder público para garantir a justiça social” ${ }^{37}$.

A viabilidade do "urbanismo cirurgico" (LE CORBUSIER, 2000, p. 245) dependia do convencimento das autoridades e Le Corbuiser dedicou boa parte de sua vida a isso. Como liderança da corrente hegemônica da arquitetura moderna no interior dos CIAM (BARONE, 2000, p. 30), a reivindicação do Estado como o principal cliente do arquiteto difundiu-se também entre os arquitetos brasileiros, debatida em todos os Congressos organizados pelo Insituto de Arquitetos Brasileiros, IAB, desde 1945.

37 Sobre o reformismo do movimento moderno: “(...) os arquitetos, como uma grande parte da inteligência da esquerda, apostavam na evolução positiva do capitalismo europeu, num momento em que a catastrofe estava batendo à porta. (...) Redigida por Le Corbusier, a carta [de Atenas] (...) registrava um desencontro patético: o fim da linha da barbárie nazista começava afinal a revelar a verdadeira face da ordem capitalista, enquanto isso, a arquitetura pretendia reconduzir o capitalismo para o bom caminho, através da regulação que o traçado regulador da cidade deveria tornar visível" (ARANTES, 2000, p. 54). 


\section{Anhaia Mello e o plano regional de São Paulo}

Anhaia Mello defendia a adesão ao urbanismo norte-americano em São Paulo, da organização de governo aos instrumentos e planos. Sua principal referência era o Regional Plan of New York and its Environs, de 1929. No intuito de conter o crescimento da metrópole, o urbanista apregoava o planejamento regional, a fundamentação do plano pela pesquisa, a abordagem multidisciplinar, a organização do território urbano a partir de unidades de vizinhança, o zoneamento, a distribuição equilibrada de indústrias e população e a contenção da expansão urbana (FELDMAN, 2005, p. 27-28).

Desde os anos 1920, o zoneamento tornou-se objeto de consenso entre os mais distintos profissionais, embora seu significado variasse conforme as concepções de quem dele se apropriava. Anhaia Mello era favorável ao zoneamento compreensivo, instrumento ordenador da utilização do solo urbano no conjunto da cidade, partindo do princípio de que diferentes regras se aplicavam a diferentes partes da cidade de forma sistemática. Além disso, o instrumento tinha o objetivo de proteger os valores imobiliários, controlando os processos econômicos ligados à utilização do solo (idem, p. 111). Essa concepção do instrumento engendrava um modelo de "cidade polinucleada, rarefeita, com uma clara hierarquia organizacional e funcional, para a qual a unidade de vizinhança, a superquadra e a cidade jardim são as referências" (idem, p. 117).

Na FAUUSP, nos anos 1950, Anhaia Mello trouxe duas importantes contribuições para o urbanismo paulista. O primeiro foi a criação do CPEU, que discutimos no Capítulo 02. O outro era um documento de 1954 em que sistematizava sua visão de planejamento urbano.

\subsection{Uma análise de “O Plano Regional de São Paulo: uma contribuição da universidade para o estudo de um código de ocupação lícita do solo (1954)"}

O documento era iniciado com uma citação extraída de “The Modern Democratic State”, de A. D. Lindsay, defendendo que a sobrevivência da democracia dependia da aplicação da sabedoria, perícia e inteligência ${ }^{38}$ para o bem das pessoas comuns. A citação era

38 Os termos empregados originalmente eram: skill, knowledge, expertness, foresight e leadership. A tradução para "sabedoria, perícia e inteligência” é de Anhaia Mello (1954, p. 08). 
pertinente, pois o que se seguia era a defesa de um saber específico - o urbanismo - cuja finalidade seria alcançar o "maior bem para o maior número". No texto, Anhaia Mello colocou-se como o porta-voz do interesse público, constituindo um lugar de autoridade a partir do qual apresentava seu argumento.

Parte do documento era dedicada a apresentar uma proposta de reestruturação administrativa do planejamento nos diversos níveis de poder. Anhaia Mello defendia o urbanismo como disciplina técnica desvinculada ao máximo da política ${ }^{39}$. Em acordo com os preceitos do regional planning, propunha a constituição de uma Comissão do Plano da Cidade e de uma Comissão Técnica que exercessem toda a autoridade municipal, executiva e legislativa relativa ao processo de planejamento (FELDMAN, 2005, p. 58). A Comissão do Plano, composta por representantes da sociedade civil, tinha o papel de garantir a estabilidade do plano e a continuidade de sua orientação, enquanto à legislação cabia o papel de concretizá-lo. A propaganda, por sua vez, criava um ambiente propício ao desenvolvimento do plano. Esses três elementos constituiam sua "árvore do urbanismo".

O ponto central da Comissão do Plano da Cidade era sua autonomia com relação ao poder municipal. Nisso, Anhaia Mello parecia ignorar a atuação dos engenheiros na administração municipal, que até os anos 1930 eram tidos em alta consideração ${ }^{40}$ (idem, p. 64). O autor dizia:

Urbanismo no sentido de "plano" é função "staff" muito característica (pesquisa, previsão, planejamento), e a Secretaria de Obras e Serviços é "linha"; nem se pode também conceber o "todo" subordinado à "parte".

Organização certa é a criação de um "Bureau de Planejamento", subordinado diretamente ao prefeito, uma espécie de super-secretaria, e também ligado diretamente à Comissão Orientadora do Plano do Município, "staff" para ambos (ANHAIA MELLO, 1954, p. 04).

Um dos princípios fundamentais levantados pelo urbanista era a correção do processo de crescimento populacional, que se dava de forma acelerada e desequilibrada no território nacional, concentrando-se em São Paulo. Através do Plano Regional, pretendia-se conter o processo metropolitano. Anhaia Mello ressaltou o problema do "gigantismo" da capital paulista (ANHAIA MELLO, 1954, p. 13), defendendo a proibição de que novas indústrias ali se instalassem e propondo sua distribuição em áreas de menor concentração demográfica. Para tanto, deviam ser melhoradas as condições das pequenas cidades, fundar novos núcleos de tipo cidade-jardim e "trading estates" ${ }^{41}$, reduzindo a população de São Pau-

39 Observar a semelhança com Le Corbusier. Feldman (2005, p.69) demonstrou que na prática a Comissão era composta por representantes de setores específicos da sociedade, que atendiam aos seus próprios interesses.

40 Isso reforça a hipótese de que Anhaia Mello procurava romper com a tradição da Engenharia Politécnica.

41 Tal proposta baseava-se no estudo desenvolvido por uma comissão designada pelo parlamento inglês em 1937, de que participava Patrick Abercrombie. 
lo (ANHAIA MELLO, 1954, p. 23) ${ }^{42}$.

Tratando das infraestruturas urbanas, o urbanista priorizou a questão energética e o sistema de abastecimento de água e coleta de esgoto. Acreditamos que o eclipsamento do transporte, por exemplo, não fosse gratuito, visto que o autor procurava fortalecer a sua proposta em contraposição ao urbanismo de "abertura de avenidas" que ele denunciava.

Anhaia Mello também propunha a criação de "cinturões verdes e lotes rurais" formando uma zona de abastecimento para a região metropolitana, enfatizando seu caráter de zona produtora (idem, p. 17). A função agrícola do cinturão verde garantia o papel de limitador do crescimento no entorno da cidade, controlando a expansão horizontal da mancha urbana. O urbanismo "criador" de Anhaia Mello era a cidade polinucleada, limitada por "muralhas verdes", distribuída no território como federação de pequenas cidades, ao invés de megalópoles (ANHAIA MELLO, 1954, p. 26-27). O enfrentamento das cidades industriais tomadas por fábricas e cortiços se daria através da cidade-jardim, traduizida como "cinta verde para limitação da extensão da cidade e abastecimento de fresh food" (idem, p. 38), da superquadra inspirada em Radburn e da unidade de vizinhança, "que permite a rearticulação social e comunitária na urbes” (idem, ibidem). Anhaia Mello reforçava o caráter totalizante do plano: "todos os elementos da cidade democrática devem ser harmonizados, relacionados, não valendo soluções parciais" (idem, p. 24, grifo do autor). O conceito de "comunidade" remetia à unidade planejada compreendendo o equipamento social, a moradia e o "recreio ativo e organizado" para o descanso do trabalhador.

A metrópole, segundo ele, concentrava grandes populações "que se cruzam, se encontram, se reunem, mas não se conhecem", que "não apenas se ignoram, mas se hostilizam abertamente". Embora contestasse o zoneamento "por classe única” (idem, p. 49), o sentido de comunidade, inspirado no exemplo norte-americano, pressupunha o apagamento das diferenças explicitadas nos conflitos vividos na metrópole, remetendo ao convívio entre iguais. Como se os problemas relacionados aos "black-belts" (idem, p. 36) pudessem ser resolvidos com a dissolução da metrópole em cidades jardins. Como Le Corbusier, Anhaia Mello defendia a propriedade pública da terra contra a especulação imobiliária, propondo seu arrendamento por longos períodos.

Anhaia Mello não reunia arquitetura e urbanismo em um único campo, mas ressaltava a importância da união entre ambos, definindo a arquitetura como "ordenação e equipamento" e o urbanismo como "coordenação" e "síntese das especialidades". Assim, embora apenas o urbanista pudesse coordenar os trabalhos, os arquitetos eram convocados a participar do planejamento enquanto especialistas na "ordenação e equipamento":

E os extremos se tocam: a Região e o Lar.

Urbanismo Regional e arquitetura.

Microcosmo e Macrocosmo.

(ANHAIA MELLO, 1954, p. 05, grifos do autor).

42 Observamos um alinhamento de Anhaia Mello com a "crítica anti-urbana" contestada por Singer nos anos 1970, para quem "a problemática das áreas metropolitanas resulta de uma concentração espacial de atividades”, e não de população (SINGER, 1985, p. 130). 
Para Anhaia Mello, as dimensões "macro" e "micro" deviam trabalhar em complementaridade: "Grandes planos regionais e pequeninos planos de vizinhança se completam, se integram", argumento que baseava nos princípios da Carta de Atenas (idem, p. 06).

A unidade regional era um todo harmônico e equilibrado que englobava os ambientes "primevo, rural, urbano e metropolitano". A esses quatro "mundos" Anhaia Mello associou as "quatro funções" da cidade moderna e os dois ritmos conforme Le Corbusier descreveu - o ritmo humano, de $4 \mathrm{~km} / \mathrm{h}$ e o mecânico, de $100 \mathrm{~km} / \mathrm{h}$. O autor não explicou como fez essas relações, deixando-as soltas no texto: "quatro mundos e quatro funções", "quatro mundos e dois ritmos". Possivelmente, com isso visava convocar os arquitetos modernos para o urbanismo de que fazia a defesa. Ainda assim, o urbanista propunha também um meio "rurbano", mostrando "o que perde o homem na superespecialização de função desses ambientes exclusivos", relativizando o funcionalismo da Carta de Atenas. Portanto, convocava os arquitetos ao mesmo tempo em que se colocava acima deles, com sua arte integradora.

\section{A participação de Artigas no planejamento municipal}

Artigas defendia que os planos diretores "norteassem (...) [o] crescimento [das cidades] e satisfizessem as necessidades de sua população" e que o problema da habitação popular fosse resolvido "em pedra e cal, cimento e ferro, nas cidades e nos campos" (ARTIGAS, 2004, p. 62). O planejamento urbano e a habitação popular eram algumas das principais pautas ligadas à Função Social da Arquitetura, difundidas pelo IAB em seus congressos desde 1945. O docente reivindicava espaço para uma atuação profissional efetiva e não apenas de "experimentação" (idem, p. 63). Esse espaço correspondia à realização de obras públicas. Artigas atuou no processo de planejamento urbano em Londrina, entre 1948 e 1955 e em Jaú nos anos 1970, quando foi contratado para desenvolver obras no âmbito de um plano diretor $^{43}$. Na década de 1970, Artigas também exerceu a função de conselheiro, sem ocupar cargos na administração pública, em cidades como Santo André e Itaquaquecetuba (GABRIEL, 2003, p. 116). Em 1957, participou com uma equipe ${ }^{44}$ do concurso de Brasília. No campo da habitação popular, desenvolveu projetos para a Companha Estadual de Casas

43 Artigas lembrava de Hugo Cabral e Waldemar Bauab como "seus prefeitos" (Artigas, 1976 apud GABRIEL, 2003, p. 116). Hugo Cabral e Waldemar Bauab foram, respectivamente, os prefeitos de Londrina e Jaú que o contrataram.

44 Carlos Cascaldi, Paulo de Camargo e Almeida e Mário Wagner Vieira da Cunha, além de outros colaboradores. 
Populares, CECAP, em diversos municípios, inaugurados com o Conjunto Zezinho Magalhães (projeto em equipe), em Guarulhos, de 1968, considerado paradigmático. Apresentamos as experiências de Londrina e Brasília, da década de 1950.

\subsection{Londrina (1948-1955), um negócio em família}

No fim dos anos 1940, foi criada a Sociedade Amigos de Londrina, SAL, constituída por membros da elite local (empresários, fazendeiros e profissionais liberais), que comandou a maior parte dos empreendimentos executados em Londrina até a década de 1960. Dela participou, entre outros, o engenheiro Rubens Cascaldi, irmão do sócio de Artigas, Carlos Cascaldi. Durante a administração de Hugo Cabral, Rubens ocupou o cargo de Diretor de Obras da prefeitura e, segundo seu irmão, foi quem abriu portas para que ele e Artigas desenvolvessem diversos trabalhos na cidade (apud SUZUKI, 2000, p. 147).

A atuação de Artigas em Londrina inscreveu-se num processo de modernização mais amplo, impulsionado pela SAL e pelo prefeito municipal, que contou com a contratação de outros profissionais modernos, como Henrique Mindlin e Roberto Burle Marx. Concomitantemente, foram contratados um urbanista, nada menos que Prestes Maia, para a elaboração do plano do município e a dupla Artigas e Cascladi para o projeto de equipamentos públicos.

O plano urbanístico de Prestes Maia para a cidade de Londrina foi concluído no fim de 1951, convertido na Lei Municipal n¹33/1951. O plano introduziu o zoneamento funcional no município, instituiu a hierarquização viária, “unidades residenciais" (Neighbourhood-unit), cidades-jardins, bairros-jardins, cidades lineares e outras concepções urbanísticas referentes a organização e conjuntos" (cf. Londrina. Lei Municipal 133/1951, Art.16).

Artigas projetou seis edifícios públicos para a cidade, dos quais apenas metade foi construída. O mais conhecido deles foi o da Rodoviária Municipal, contratado pela prefeitura em 1948, tendo sua obra concluída em 1952. Também foi empreendida a reforma da Santa Casa Misericordiosa de Londrina, 1952-1955, e, por iniciativa da SAL, construiu-se a Casa da Criança, 1952-1955, primeira creche do município. Os projetos não executados foram o Hospital Municipal, 1948, um Estádio e Conjunto Poliesportivo Municipal, 1953, além de um aeroporto,1955. Segundo Suzuki (2000, p. 241), o principal motivo para a não construção desses projetos foi o superdimensionamento dos mesmos para a época. 


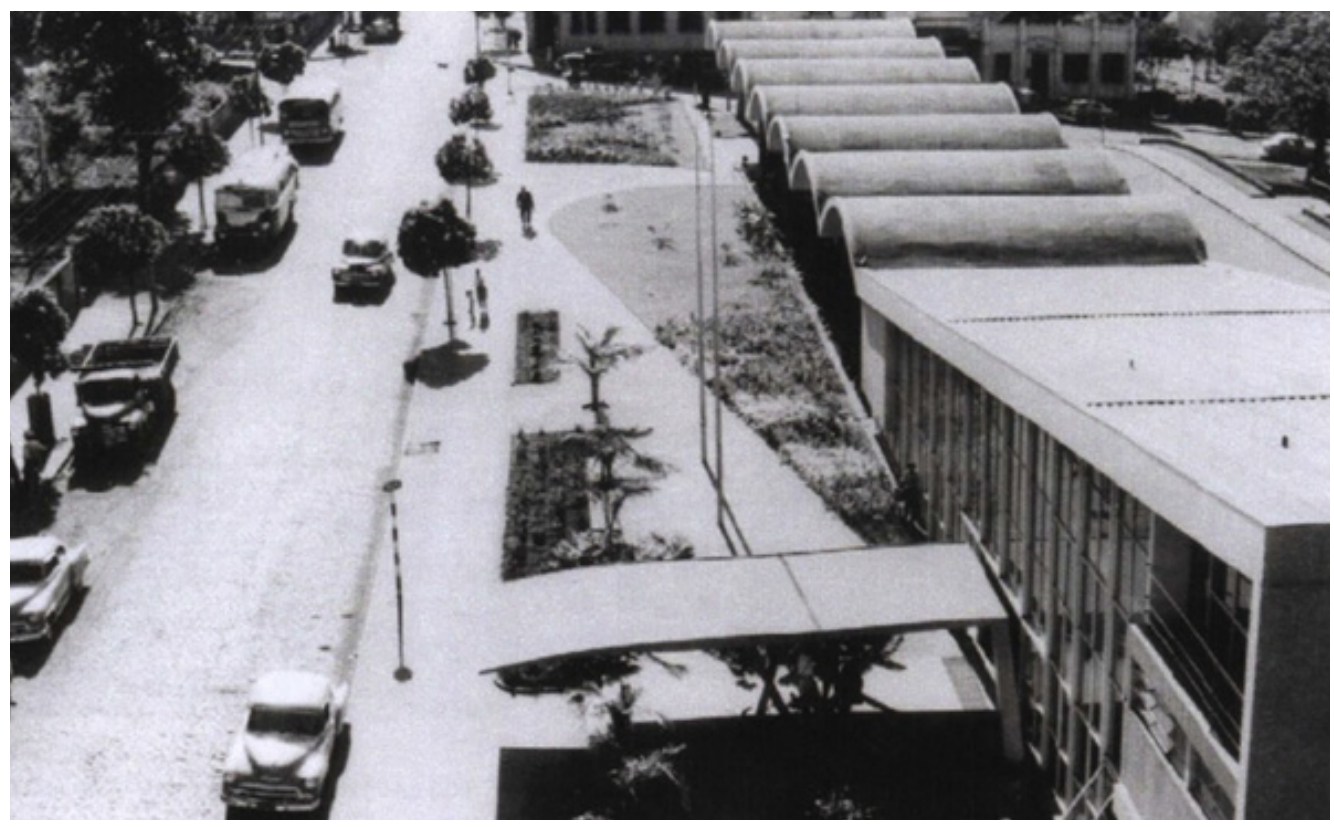

Figura I6 - Artigas e Carlos Cascaldi. Rodoviária de Londrina, 1948-1952.

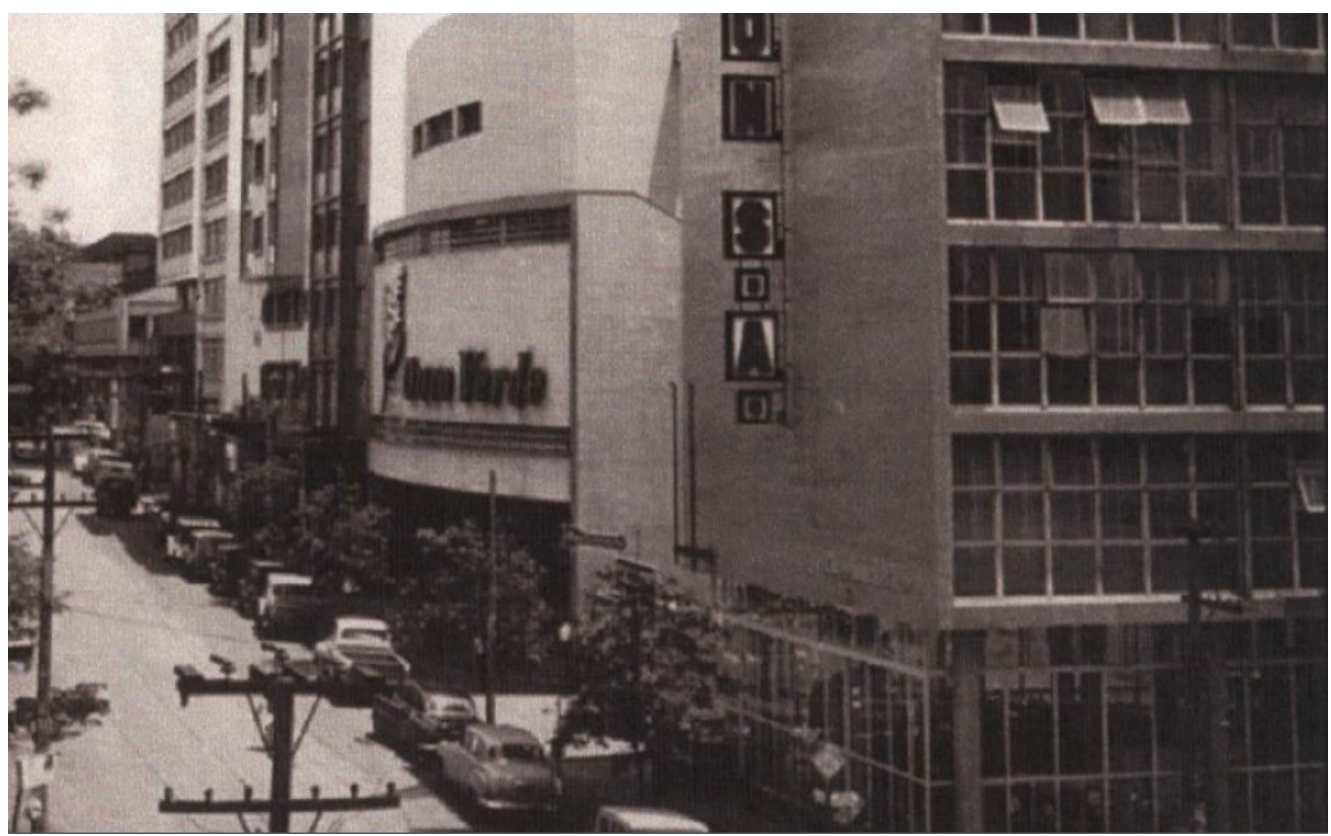

Figura I7 - Artigas e Carlos Cascaldi. Edifícios Autolon e Cine Ouro Verde, Londrina, 1948-1952.

Chama a atenção a participação da SAL nesse processo. Além da importância de sua atuação na viabilização daqueles equipamentos públicos, Artigas desenvolveu projetos para uma série de edifícios privados no mesmo período, em sua maioria para os membros daquela organização. Era o caso do edifício Autolon, 1948-1951, e do Cinema Ouro Verde, 1948-1952. Artigas também projetou a residência de Milton Ribeiro de Menezes ${ }^{45}$ em 1952 e os vestiários do Londrina Country Clube, também em 1952. Entre projetos não construídos, estavam o Ginásio de Esportes do Country Clube de Londrina, 1950, o Posto Transparaná, 1950, e o Posto de Serviço para a Sociedade Autolon, para abrigar oficinas da Chevrolet, de 1951.

45 Milton Ribeiro de Menezes foi prefeito de Londrina entre 1951 e 1955, dando continuidade às obras contratadas por Hugo Cabral. 
Com relação à atuação de Artigas no município, Gabriel avaliou que "mais que um conselheiro técnico, tratava-se de poder dar forma a uma cidade que contava na época com 25 a 30 mil habitantes e, 25 anos mais tarde, já estava na casa dos 300 mil” (GABRIEL, 2003, p. 116).

Rubens Cascaldi foi responsável pela execução das obras. Ainda que Londrina estivesse distanciada do debate sobre arquitetura moderna que se desenrolava nos grandes centros do país (SUZUKI, 2000, p. 268), o anseio da SAL por modernização e as relações familiares que levaram à contratação dos arquitetos garantiram à dupla Artigas e Cascaldi certo grau de liberdade criativa para realizarem projetos de arquitetura moderna, ao modo corbusiano.

A atuação de Artigas em Londrina revela o entendimento do plano como desenho da cidade e suporte para realização de edifícios públicos, concepção alinhada com as ideias apresentadas por Le Corbusier no início do século e diversa daquela apresentada por Anhaia Mello em 1954. Tanto que Artigas não participou da elaboração do projeto de lei a cargo de Prestes Maia. Sua postura diante dos administradores públicos era análoga à do franco-suíço no que se refere à sedução pelo Estado como cliente.

\subsection{Brasília}

O projeto de Artigas para Brasília foi classificado em $5^{\circ}$ lugar. Uma das características que chamaram a atenção do júri foi a apresentação de uma proposta de desenvolvimento regional, calcada em amplo diagnóstico. A cidade para 550.000 habitantes foi pensada para o exercício de sua função de centro administrativo do país com toda eficiência. Seus idealizadores queriam evitar a constituição de um pólo industrial, turístico e comercial, como no Rio de Janeiro, que acarretaria um deslocamento em massa (BRAGA, 2011, p. 95). As atividades ligadas ao abastecimento da capital foram redirecionadas para uma rede de vilas e cidades do entorno. Brasília deveria ter um tamanho mínimo e apenas os serviços condizentes com as necessidades de seus habitantes, predominantemente servidores públicos.

A população distribuía-se em três setores: um destinado aos servidores federais, civis e militares; outro para o que chamavam de população "colateral" - turistas, pessoas em trânsito ou pessoas que mantivessem relações diplomáticas ou de negócios com o governo -; e o terceiro para a população “derivada”, os trabalhadores do setor de serviços da cidade (idem, p. 97). Foi também proposto um setor para acolher os operários envolvidos na construção da nova capital, embora também constituíssem a "população derivada", "evitando-se (...) a criação de uma cidade paralela, dificilmente provisória” (idem, p. 98). Esse setor deveria tornar-se a área residencial da zona industrial, considerando-se que os operários da construção seriam redirecionados para essa atividade econômica. 


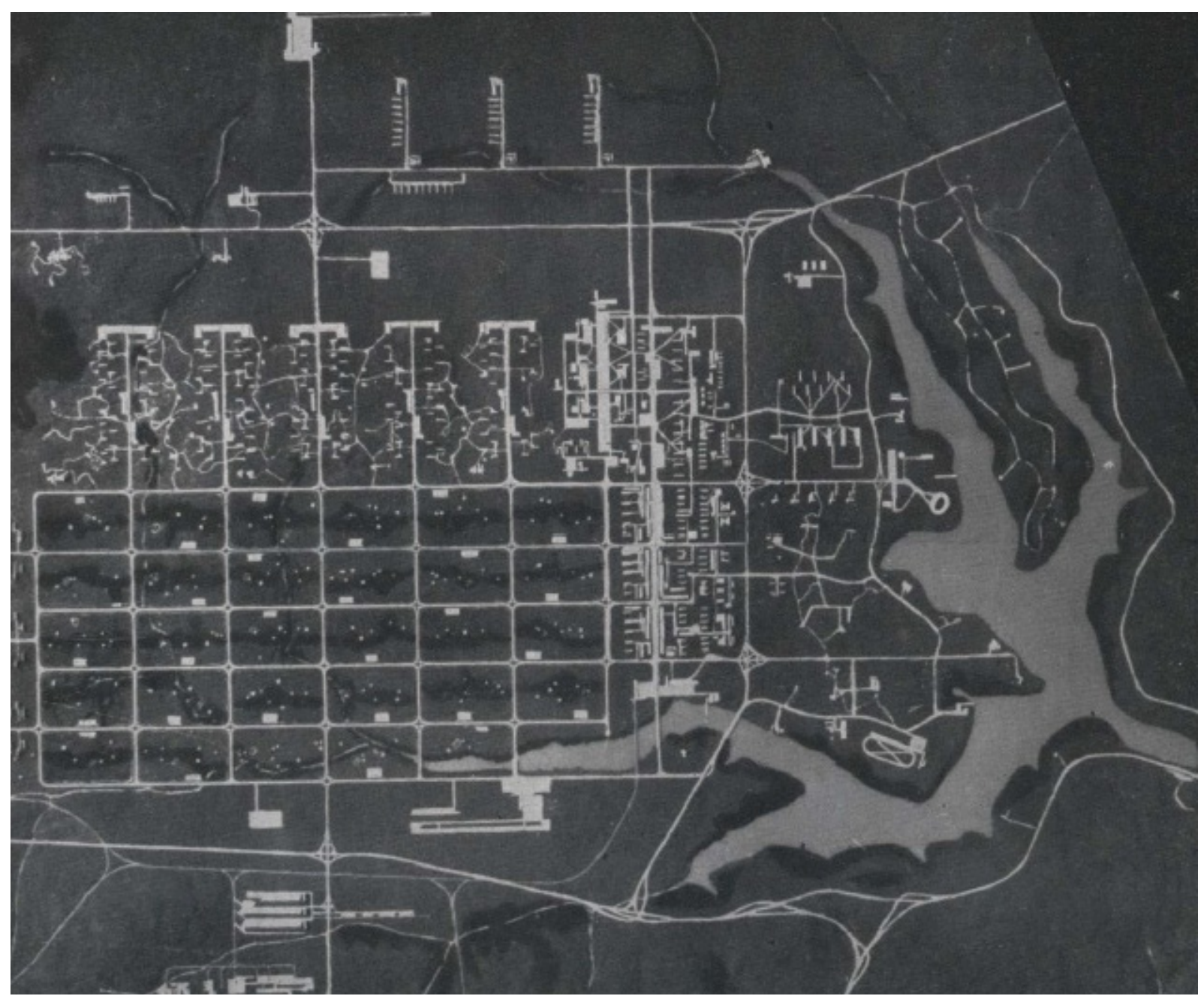

Figura I8 - Artigas e equipe. Projeto de Brasília: Vista Aérea, 1957.

Observa-se na proposta de Artigas a adoção dos conceitos defendidos por Anhaia Mello e a sua mesma preocupação com o controle do crescimento urbano decorrente dos processos migratórios. Como o mestre, que manifestou o seu horror diante da condição dos cortiços e dos bairros periféricos de São Paulo, entendidos como resultado da industrialização não planejada, Artigas procurava evitar o "inchaço" de Brasília, redirecionando todas as atividades não-administrativas para fora dela e apresentando uma "solução" para o destino dos candangos. Podemos estabelecer uma relação entre a proposta de Anhaia Mello de proibir novas indústrias na capital com a criação de um setor para os operários da construção civil convertidos em operários da indústria.

O plano, que organizava a totalidade urbana e a articulação entre suas partes, previa uma estrutura em quadrícula junto ao lago Paranoá. Além das Zonas Residenciais, situadas junto à represa, ao norte e a oeste, e da Zona Industrial (no extremo oeste do plano), havia uma Zona Militar no extremo norte e um Centro Geral de Abastecimento no Extremo Sul. O "centro cívico" continha, além dos edifícios administrativos, equipamentos culturais. Havia duas zonas comerciais, uma central e outra periférica. Uma área verde contínua formava a partir da ligação da "Zona Verde 1", Parque Nacional que realizava as funções de "Centro Cultural Recreativo Regional e Nacional", abrigando instituições públicas como a Cidade Universitária, um hospital, equipamentos esportivos, etc.; com a "Zona Verde 2", extensão do Parque Nacional com função recreativa e com a "Zona Verde 3", outra extensão do parque ocupada por jardins periféricos e delimitada pelas rodovias perimetrais (BRAGA, 
2011, p. 100). O sistema de circulação previa a hierarquização funcional das vias, classificadas em vias de "trânsito rápido intermunicipal", "trânsito rápido urbano", "tráfego local", “marcha a pé”, além de "via rural". A propriedade pública da terra e seu arrendamento para uso particular, recomendação presente na Carta de Atenas e em Anhaia Mello, devia proteger contra a especulação imobiliária.

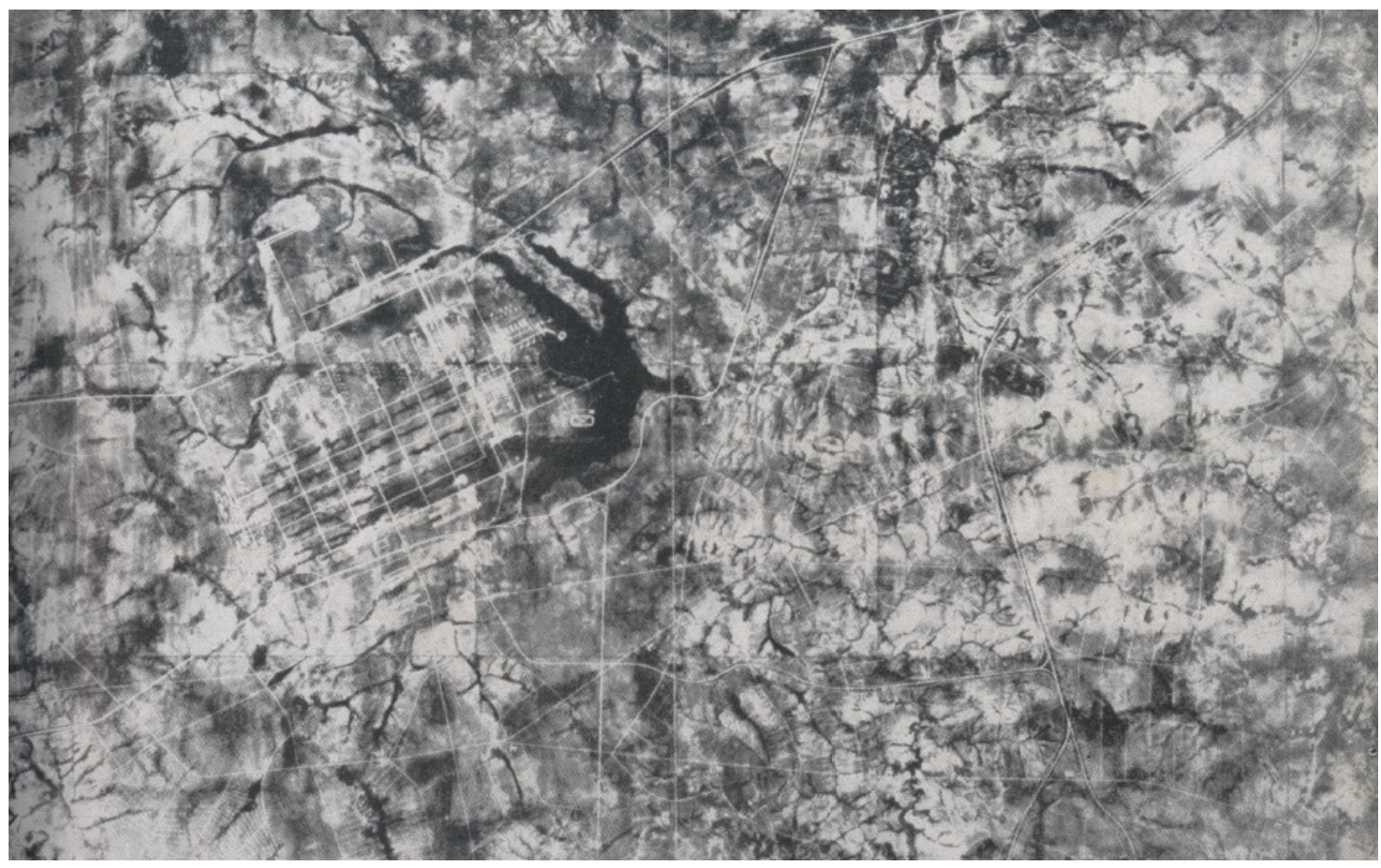

Figura I9 - Artigas e equipe. Projeto de Brasília: Plano Regional, 1957.

Chamamos a atenção para o caráter anti-metropolitano da proposta, expresso por um plano regional e a correspondente tentativa de equacionar as condições de vida no campo. A baixa densidade populacional - em 20 anos, previa-se uma densidade de 50 hab/ ha - era a mesma dos bairros jardins de São Paulo. Essa proposta dava ênfase à busca de "equilíbrio e isolamento geral da cidade na escala regional, o mesmo pretendido na escala nacional" (MEDRANO \& RECAMÁN, 2014, p. 112). O fenômeno metropolitano, entretanto, não foi rejeitado unicamente por Artigas, dentre os arquitetos brasileiros:

Para a vanguarda da arquitetura brasileira, em especial de São Paulo, a hipótese do reforço da dimensão coletiva da cidade não se mostrou oportuna no momento de sua metropolização, nos anos 1950. A ênfase na concentração formal e programática (...) tem sua origem na fragmentação territorial desse processo de expansão urbana desordenada, da qual parece poder ser um comentário crítico (idem, p. 97-98). 
Numa perspectiva autocrítica, durante debate realizado no IAB em 1979, Artigas caracterizou-se a si e a seus colegas à época do I CBA de "desurbanistas", "fazendo o possível para que as cidades não crescessem" (ARTIGAS, 2004, p. 146). Esse desurbanismo, conforme sua explicação, consistia em "tomar uma posição na contradição entre cidade e campo pelo lado unicamente espacial, forçando o homem do campo a viver lá sem atingir a cidade, [o que] significa ir contra um alinhamento já provado como inevitável" (idem, p. 149). Segundo seu filho, Artigas não gostava de sua proposta para Brasília, reconhecendo a superioridade do Plano Piloto de Lúcio Costa (apud BRAGA, 2011, p. 93). Seus depoimentos, assim como seu desgosto com relação ao plano apresentado sinalizam uma falta de clareza por parte do arquiteto a respeito dos princípios que deviam reger o urbanismo naquele momento.

\section{Considerações sobre a continuidade e divergência entre os pensamentos de Artigas e Anhaia Mello}

Entre as visões de Artigas e de Anhaia Mello acerca do urbanismo, podemos considerar que houve continuidades e divergências. Os princípios da Carta de Atenas, especialmente o zoneamento funcional e o planejamento regional foram denominadores comuns entre o pensamento de Artigas e de Anhaia Mello. Cidade-jardim, unidade de vizinhança, superquadras, cinturão verde, defendidos por ambos profissionais, foram consolidados a partir de vertentes tão distintas quanto o regional planning norte-americano, o movimento das cidades jardins e o movimento racionalista de Le Corbusier, durante a primeira metade do século XX. Havia diferenças na forma de sua aplicação de acordo com a orientação do profissional. De toda forma, podemos considerar que Anhaia Mello também exerceu influência sobre Artigas.

A ideia de funcionalidade, expressa no zoneamento funcional, foi o instrumento que uniu os interesses dos arquitetos brasileiros apoiados nos preceitos dos CIAM e sobretudo, na influência de Le Corbusier, e de Anhaia Mello na defesa de sua "árvore do urbanismo". Entretanto, o zoneamento funcional expresso na Carta de Atenas não correspondia ao zoneamento de Anhaia Mello, como observou Lira:

Para Anhaia, o zoneamento, espinha dorsal do urbanismo, não se confundia com o zoneamento modernista, mas apresentava uma história própria. Havia nascido como forma de restringir o uso indiscriminado da propriedade urbana, criando para tal distritos com parâmetros diferenciados de ocupação e edificação, de modo a proteger as áreas residenciais (e bairros jardins) de usos incompatíveis e garantir, com isso, a integridade estética da cidade e a 
escala humana da aglomeração urbana. Em outras palavras, "antes de aderir ao zoneamento funcional modernista - que destacava a eficiência da separação entre usos -, Anhaia Mello defendia um zoneamento protetor e regulador" (LIRA, 2005, p. 10).

Acerca da relação entre profissionais e o Estado, o urbanismo de Anhaia Mello dependia de uma reestruturação administrativa municipal, que o dotasse de grande autonomia, respondendo unicamente ao prefeito, sendo instituído enquanto um "quarto poder" (FELDMAN, 2005, p.70). Artigas, endossando as proposições do IAB, defendia o comissionamento do arquiteto pelo Estado, retomando assim o empenho corbusiano em seduzir o Estado para aderir à arquitetura moderna, ainda que não tivesse plena consciência sobre a influência de Le Corbusier nesse empreendimento.

Em Londrina essa postura é evidente. Nos anos 1950, tratava-se de convencer as autoridades a assumirem a arquitetura moderna e projetar os equipamentos públicos definidos no plano ou não. No caso de Londrina, não constatamos a colaboração de Artigas com Prestes Maia. A maioria de seus projetos antecedeu a aprovação do plano. Assim, é difícil corroborar a ideia de que Artigas tenha participado do planejamento de Londrina, interpretação de alguns autores. Foi, antes, uma ocasião oportuna para por em prática a arquitetura moderna em edifícios públicos e privados.

Até aqui, discutimos a produção de Artigas e Anhaia Mello no âmbito profissional. Entretanto suas principais divergências ficam mais evidentes quando analisamos suas atuações no âmbito institucional, tendo em vista as posições do IAB-SP e, especialmente, a institucionalização da arquitetura moderna.

Como mencionamos anteriormente, a partir 1956, Artigas integrou uma comissão do IAB que pretendia revisar a regulamentação da profissão do arquiteto. O projeto de lei, apresentado ao CREA em 1958, dentre outras questões, reivindicava a criação de um órgão profissional específico de arquitetura e que o urbanismo fosse atribuição exclusiva do arquiteto, divergindo, portanto, da posição de Anhaia Mello, que defendia o urbanismo como "ciência multidisciplinar". O urbanista foi designado pela Congregação da Escola Politécnica para elaborar um parecer sobre a proposta. Respondendo enquanto diretor do CPEU, posicionou-se contrariamente ao projeto, declarando que o "conceito de exclusividade está hoje superado, porque o próprio urbanismo já superou a fase arquitetônica, dos arranjos urbanos, e percorre a estrada larga das considerações sociológicas e humanas na ordenação territorial" (Parecer de 11/11/1958).

Fica patente a diferença dos conceitos de "plano" adotados. Para Anhaia Mello, tratava-se de um instrumento cujo produto devia ser um projeto de lei, realizado em consonância com diferentes forças da sociedade civil. Por isso o urbanismo devia ser uma ciência multidisciplinar e não podia ficar a cargo de uma única especialidade. Para Artigas e seus colegas do IAB, o plano devia ser o suporte para a realização de edifícios modernos. Era esse plano, e não aquele defendido por Anhaia Mello, que esses arquitetos reivindicavam na proposta de regulamentação profissional. Contudo, essas diferenças ficaram escondidas sob a adoção de um vocabulário que remetia a conceitos em comum. Trazendo essas diferenças à tona, acreditamos estar contribuindo para a construção de uma outra perspectiva de compreensão do próprio desenvolvimento do campo de arquitetura e urbanismo em São Paulo. 


\section{CONSIDERAÇÕES}

FINAIS 
Ao longo do desenvolvimento deste trabalho, procuramos demonstrar que a fundação da FAUUSP, com a participação dos agentes analisados, foi parte importante do processo de institucionalização do campo profissional de arquitetura e urbanismo em São Paulo. Essa nova instituição repercutiu sobre a forma como esse campo se consolidou a partir dos anos 1950. Separando-se da engenharia, encaminhou-se a construção de um espaço de formação em que a arquitetura moderna se tornaria finalmente a linguagem hegemônica em São Paulo e, ao mesmo tempo, instituiu-se um lugar para o desenvolvimento de um urbanismo autônomo, rompendo com a tradição urbanística precedente, oriunda da Escola Politécnica.

No processo de fortalecimento institucional da arquitetura moderna em São Paulo nos anos 1940, Anhaia Mello, ao ter sob sua responsabilidade a criação da Faculdade de Arquitetura e Urbanismo, encontrou uma possibilidade de, unindo-se a esses arquitetos, fortalecer-se perante a engenharia politécnica e construir um espaço para realizar o seu próprio projeto. Os arquitetos, por sua vez, beneficiando-se da posição de Anhaia Mello como docente catedrático da Universidade de São Paulo e de sua disposição em criar uma faculdade de arquitetura moderna, puderam ver consolidado um espaço institucional fundamental para seu próprio campo. Tratava-se do lugar em que seriam formadas as novas gerações de arquitetos de São Paulo, sob os preceitos da arquitetura moderna. Nesse sentido, a união entre arquitetura moderna e urbanismo, especialmente através da aliança entre Anhaia Mello e Artigas, conforme relatamos neste trabalho, foi de grande proveito para ambos grupos de interesse e a partir dela construiu-se a relação entre arquitetura e urbanismo na Universidade de São Paulo. Avançando na direção da "Função Social da Arquitetura", tal como vinha sendo formulada naquela década pelos arquitetos modernos brasileiros, o urbanismo e, ligado a dele, o plano, bem como a questão da habitação social constituíram pontos de tangência entre arquitetura e urbanismo. Ao mesmo tempo, Anhaia Mello convocava os arquitetos a participar de seu projeto para o planejamento regional.

A fundação da FAUUSP como parte de uma estratégia para a realização de dois projetos distintos, relativos a dois grupos de interesses independentes entre si - a afirmação da hegemonia da arquitetura moderna em São Paulo e a consolidação de um campo de urbanismo autônomo sob determinadas prerrogativas - dependia de que, naquele momento, os alinhamentos e afinidades entre os dois grupos fossem evidenciados e que as divergências não fossem discutidas. Nesse sentido, elementos que se constituiriam como efetivos pontos de tangência entre arquitetura e urbanismo, mas que, trazidos à tona, suscitariam uma explicitação dos diferentes entendimentos sobre eles, não foram levantados. Dentre esses elementos, podemos mencionar questões como o papel da indústria na arquitetura e no urbanismo, a habitação popular, os "interesses do povo". São questões que criam pontos de tangência entre arquitetura e urbanismo e onde é possível perceber divergências nas posições de Anhaia Mello e de Artigas. Esses aspectos não foram explorados neste trabalho, sinalizando, todavia, possíveis desdobramentos desta pesquisa.

Gostaríamos de destacar que o papel de Anhaia Mello na formação do campo de arquitetura em São Paulo não havia ainda sido objeto de uma detida atenção, apesar de sua importância. É notável que o urbanista tenha assumido a defesa da arquitetura moderna, trazendo para próximo de si, ainda na Escola Politécnica, profissionais que se notabilizaram como importantes representantes deste movimento, como seus assistentes Zenon Lotufo e o próprio Artigas. Isso interferia diretamente sobre o curso ministrado em sua cadeira, o 
que era, certamente, uma decisão conscientemente tomada. Anos antes, enquanto presidia o Instituto de Engenharia, acolheu a vinda de Le Corbusier para São Paulo em 1929, possibilitando que o arquiteto professasse suas conferências na sede da organização. Muitos dos profissionais que vieram a desenvolver a arquitetura moderna em São Paulo haviam sido seus alunos na Escola Politécnica, como Artigas, Zenon Lotufo, Roberto Cerqueira César, Ícaro de Castro Mello, Oswaldo Corrêa Gonçalves, Leo Ribeiro de Morais, entre outros. Tudo isso parece revelar um projeto que se consagrou na fundação da nova faculdade, quando observamos o apoio mútuo entre arquitetos ligados ao IAB, modernos, e Anhaia Mello. Esse apoio ultrapassava a própria instituição universitária, como a presença do urbanista na diretoria do IAB-SP entre 1947 e 1949 indica. Desligar-se da engenharia e assim constituir o campo de urbanismo autônomo sob as premissas que defendia correspondia à defesa do projeto moderno. Nesse sentido, era necessário aliar-se àqueles que compartilhavam o interesse na realização do projeto de modernidade nacional, ainda que houvesse divergências de posições entre eles.

O empenho de Anhaia Mello em fundar uma escola de arquitetura moderna pode ser comprovado em diversas ocasiões no processo de elaboração desta pesquisa. Observamos a iniciativa de compor um corpo docente orientado para esse objetivo já em 1948. O catedrático enfrentou, inclusive, a própria instituição universitária com essa finalidade, a exemplo do ocorrido em 1951, quando se esforçou por contratar Oscar Niemeyer para a cadeira de "grandes composições" e o insucesso dessa tentativa levou-o, dentre outras motivações, a abdicar de todos os cargos dirigentes que então ocupava. Ademais, o depoimento de docentes à época confirma esse empenho, como observamos quando Abelardo de Souza relatou que fora enviado ao Rio de Janeiro em 1949 com o objetivo expresso de conversar com Lúcio Costa com vistas a melhorar a orientação da FAUUSP (Apêndice D).

Se, por um lado, nos anos 1940 o campo de arquitetura começou a institucionalizar-se, notadamente com a fundação do IAB-SP em 1943, as instituições de ensino ainda permaneciam espaços a serem conquistados por esses profissionais. Em 1947, a faculdade de arquitetura do Mackenzie recém-separada do curso de engenharia tinha por fundador e diretor Christiano Stockler das Neves, veemente opositor da arquitetura moderna. Portanto, a oportunidade de criar uma escola moderna dentro da Universidade de São Paulo era de extremo interesse. Todavia, deve-se lembrar de que a USP e, dentro dela, a Escola Politécnica, a partir da qual deveria ser fundada a FAUUSP, eram instituições conservadoras e que se não fosse a disposição de Anhaia Mello em fundar uma escola moderna, muito provavelmente a nova faculdade seria distinta. Nesse processo, não pode ser negligenciado o papel de Artigas que, inserido na instituição universitária, sendo assistente de Anhaia Mello e designado por este para criar o curso de arquitetura, fez uma importante intermediação entre os interesses universitários e os dos arquitetos empenhados na criação da escola. Isso pode ser observado, por exemplo, em sua carta a Oswaldo Gonçalves Corrêa, em 1946, enquanto realizava sua viagem aos Estados Unidos com o objetivo de conhecer o sistema de ensino de arquitetura norte-americano para subsidiar a implantação da FAUUSP.

A posição de assistente de Anhaia Mello abriu importantes portas a Artigas. Gabriel (2003) já havia demonstrado isso, ao assinalar que seu cargo de docente garantiu-lhe uma estabilidade financeira que lhe favoreceu seguir uma carreira autônoma, desvinculando-se da sociedade com Duílio Marone em 1944. Entretanto, acreditamos que a atividade docente junto a Anhaia Mello tenha sido ainda mais importante para a carreira do Arquiteto. A 
própria viagem aos Estados Unidos, que o fez travar contato com a produção de grandes mestres da arquitetura moderna, sendo decisiva para o desenvolvimento de sua própria arquitetura, como demonstra o trabalho de Irigoyen (2002), só foi possível em função de sua inserção na Escola Politécnica e do apoio de Anhaia Mello. Mais do que isso, em seu projeto de construção de uma faculdade de arquitetura e urbanismo moderna, Anhaia Mello garantiu a Artigas um lugar privilegiado. Artigas fundou a FAUUSP com Anhaia Mello e tornou-se um dos professores mais importantes daquela escola, projeção que certamente contribuiu para que viesse ocupar lugar tão proeminente na historiografia da arquitetura paulista. Nesse sentido, deve ser assinalado que o mestre, a despeito de importantes conquistas alcançadas na criação da faculdade, tendeu a ficar acobertado pelo brilho de seu discípulo. Além do caráter diferente da arquitetura e do urbanismo - o primeiro como movimento estético e o segundo como atividade essencialmente política, que dão visibilidades distintas aos profissionais que as realizam, devemos considerar como o próprio Artigas entendia a sua atividade profissional. Para ele, a arquitetura possuía um forte caráter autoral, ao passo que o urbanismo, especialmente aquele defendido por Anhaia Mello, era o produto de um trabalho multidisciplinar, ainda que coordenado pelo urbanista.

Curiosamente, mesmo com essa projeção maior de Artigas do que do próprio Anhaia Mello, não se pode considerar que essa posição tenha sido humildemente aceita pelo urbanista. Pudemos recolher evidências da importância que tinha para o urbanista notabilizar-se como autoridade em sua disciplina. Seus discursos revelam essa posição e a criação do CPEU consagrou-o nesse sentido. A partir de então qualquer posicionamento acerca de questões de urbanismo era feito em nome do diretor de um centro de pesquisa especializado em urbanismo da Universidade de São Paulo. Além disso, em todo o período em que esteve na FAUUSP, Anhaia Mello manteve-se como o único urbanista a sobressair-se, assumindo a liderança do CPEU e do curso de urbanismo para a graduaçãos. Possivelmente, o desejo de notabilizar-se como alguém "único" em seu campo de atuação aproxime dos dois profissionais estudados neste trabalho. Em contrapartida, observando o corpo docente de composição, esse era muito mais plural, constituído por arquitetos dos mais proeminentes, que trouxeram grandes contribuições tanto para a consolidação da FAUUSP como importante instituição de ensino quanto para o campo profissional e, evidentemente, para a produção de arquitetura na cidade. Poderíamos ser levados a crer que isso se devia ao maior número de cadeiras de composição, ao passo que havia uma única cadeira de urbanismo. Entretanto, enquanto nenhum desses arquitetos eram catedráticos, como Anhaia Mello, lecionaram na condição de assistentes arquitetos tão qualificados quanto os responsáveis pela cadeira. Isso se observa na cadeira compartilhada por Artigas e Abelardo de Souza, na de Zenon Lotufo e Artigas, de Ícaro de Castro Mello e Oswaldo Corrêa Gonçalves, de Hélio Duarte e Ernest Robert de Carvalho Mange. A relação entre os professores responsáveis e seus assistentes eram, no mais das vezes, uma relação horizontal, de colegas de trabalho - inclusive fora da faculdade - e não de um superior e seu subordinado. Possivelmente, o único caso em que isso destoe um pouco seja na cadeira regida por Rino Levi, um dos arquitetos mais antigos a praticar arquitetura moderna em São Paulo. Na FAUUSP, seus assistentes foram, na maior parte do tempo, seus sócios, mas que ainda assim pertenciam a uma geração mais nova e haviam ingressado no seu escritório como estagiários.

Em 2010, a Lei $n^{\circ} 12.378$ finalmente criou o Conselho de Arquitetura e Urbanismo, efetivando a separação do órgão profissional daquele responsável pela engenharia, o sistema 
Confea/CREA. Essa luta, como pudemos observar, é, contudo antiga, sendo debatida já nos primeiros CBA. Entre 1958 e 1959, o IAB-SP já havia tentado efetivar essa separação. Entretanto, é interessante notar que muito embora possa parecer tratar-se de uma iniciativa do movimento moderno de arquitetura, essa luta é mais antiga, já sendo levantada pelos arquitetos acadêmicos ligados à Belas Artes desde os anos 1920. As atribuições por meio das quais os arquitetos procuram distinguir-se dos engenheiros passam pela defesa da atividade de projeto (em oposição à construção) e pelo direito autoral do projeto, assim como pela instituição de concursos de arquitetura para obras públicas, ideias defendidas por Christiano Stockler das Neves, nos anos 1920, e pela defesa do urbanismo como atividade do arquiteto, propalada também por José Marianno Filho em 1930.

É interessante observar que na luta por consolidar o campo de arquitetura, a relação entre arquitetura e urbanismo foi construída principalmente através da da atribuição profissional. Antes de procurar definir o urbanismo ou o planejamento urbano, ou então de analisar os pontos de tangência entre os campos de arquitetura e urbanismo, tratava-se de disputar com os engenheiros quem deveria ser o profissional responsável por assinar os trabalhos. A definição das atribuições profissionais (urbanismo, projeto, etc.) que delimitavam o campo de arquitetura, em disputa com os demais, constituiu uma das mais importantes estratégias para a sua institucionalização, para o que a atuação do IAB foi de notável importância. Nisso, a arquitetura difere do urbanismo, para o qual a institucionalização do campo devia ser necessariamente, além de técnica, de ordem política, incidindo sobre a estrutura da administração pública.

A FAUUSP notabilizou-se como uma importante escola de urbanismo ou de planejamento urbano. A contribuição de Anhaia Mello para esse processo tem que ser trazida para o debate, pois acreditamos que muito do que é produzido até hoje em matéria urbanística na escola é devedor de seu pensamento. Não foi um objetivo desta dissertação traçar uma linhagem do urbanismo desenvolvido na FAUUSP desde sua fundação até o presente e, portanto, essa questão permanece em aberto. Contudo, não podemos deixar de assinalar a pertinência de se pensar o quão devedor o urbanismo atualmente produzido na FAUUSP (e não apenas) é daquele formulado nas origens da escola, elaborado no CPEU de Anhaia Mello.

Em 1946, no parecer acerca da doação da mansão Penteado para abrigar a nova faculdade apresentado à Congregação da Escola Politécnica, Anhaia Mello reforçou que o curso ministrado em uma escola de engenharia já não atendia às necessidades emergentes no campo da arquitetura e do urbanismo. Segundo o docente, o século XX assistira a uma evolução social sem precedentes, de modo que a arquitetura devia ir muito além da composição formal praticada à época de fundação do curso de engenheiros arquitetos. Segundo ele, a arquitetura adequada ao novo tempo deveria abranger toda a ciência de planejar. Portanto, em um discurso alinhado com o dos arquitetos modernos, Anhaia Mello denunciava o método compositivo em arquitetura, demandando sua superação. Nesse momento, contudo, o urbanista reivindicava a arquitetura como "ciência de planejar" o que estabelecia uma interface entre arquitetura e urbanismo, justificando a criação da nova faculdade. Portanto, "a ciência de planejar", ou o plano como interface entre arquitetura e urbanismo foi defendida 
pelo urbanista e pelos arquitetos naquele momento. Isso é muito significativo, pois mostra que a ideia de unificação dos campos interessava tanto a Anhaia Mello quanto aos arquitetos envolvidos com a arquitetura moderna e foi um argumento fundamental para legitimar a criação da faculdade, visando a separação da engenharia, que já não mais dava conta de ministrar os conteúdos necessários ao "arquiteto do novo tempo".

No entanto, na FAUUSP foram os arquitetos que tomaram a iniciativa de unir os dois campos. As tentativas (e frustrações) de articular as cadeiras de composição e de urbanismo no fim dos anos 1950, especialmente após a criação do CPEU, revelam divergências que haviam sido silenciadas por ocasião da fundação da FAUUSP. Nas cadeiras de composição, foi lançada a proposta de partir-se de um plano diretor para projetar os equipamentos identificados como necessários naquele plano. Assim, a arquitetura perpetuava-se como subordinada ao urbanismo, tal como Anhaia Mello pretendia desde sua época de docente do curso de engenheiros arquitetos. Os conflitos começaram a aparecer justamente quando os trabalhos desenvolvidos nas cadeiras de composição "ultrapassaram seu âmbito de atuação", passando a serem realizados "planos urbanísticos", interferindo sobre o que o responsável pela cadeira de urbanismo considerava ser sua atribuição. Esse conflito está indicado nos programas de 1962, introduzidos com considerações acerca da necessidade de se respeitar os limites de cada cadeira, não sendo, portanto, permitido desenvolver trabalhos de urbanismo. Todavia, é necessário assinalar que o "urbanismo" desenvolvido nas cadeiras de composição diferia daquele ensinado na cadeira de urbanismo, em função dos pressupostos distintos do que seria essa disciplina para a arquitetura moderna e para Anhaia Mello, conforme procuramos explicitar no último capítulo desta dissertação. Após esse incidente, a parceria entre as cadeiras de composição, de urbanismo e do CPEU foi abandonada pela maior parte dos docentes e só viria a ser retomada mais à frente, nos anos 1960, após a reforma de 1962 - portanto, após a saída de Anhaia Mello - quando foram realizadas diversas experiências de "ateliê vertical" que lidavam simultaneamente com as várias sequências de projeto - planejamento, projeto de edifício, desenho industrial e comunicação visual. Ainda assim, em muitos casos os trabalhos eram coordenados pela cadeira de planejamento.

A tentativa de integração entre as cadeiras de composição e urbanismo refletiam os debates sobre ensino que ocorriam na escola desde o início do seu funcionamento, mas que se intensificaram a partir de 1956. Essas discussões interessavam muito mais ao corpo docente de composição, que constituiu todas as comissões de ensino visando a reforma curricular que afinal se consolidou em 1962. Ao mesmo tempo, elas coincidiam com a elaboração da proposta de regulamentação profissional em que se separava o órgão profissional de arquitetura do de engenharia, transferindo a atribuição do urbanismo para os arquitetos.

Se o plano foi o argumento para unificar os campos de arquitetura e urbanismo no discurso, na prática, isso teve muita dificuldade em se concretizar dentro da nova faculdade, como acabamos de relembrar. Defendemos que um dos principais motivos para que isso tenha se dado dessa forma seja que, à revelia desse discurso em comum, os arquitetos e o urbanista remetiam a significados distintos do que fosse o plano. Buscando as referências que informaram os pensamentos de Anhaia Mello e de Artigas e demais arquitetos vinculados ao IAB-SP, percebemos que embora adotem um léxico em comum - plano diretor, planejamento regional, zoneamento, aspecto social, etc. - que foi utilizado por praticamente todas as vertentes do pensamento urbanístico do século XX, os profissionais vislumbravam realidades distintas. Anhaia Mello, pautado sobretudo pelo Regional Planning norte-ameri- 
cano, defendia um urbanismo multidisciplinar, que deveria contar com uma reestruturação da administração municipal visando dotá-lo da maior autonomia possível. O plano deveria ser o instrumento por meio do qual seria garantido o controle do crescimento. Previa-se a elaboração de leis de zoneamento e de uso e ocupação do solo para proteger as propriedades e regulamentar a ocupação da cidade.

A visão de plano dos arquitetos ligados às cadeiras de composição era muito mais referenciada no urbanismo do movimento moderno em arquitetura, consagrado nos CIAM e, sobretudo, a partir do trabalho de Le Corbusier. Esse entendimento de urbanismo correspondia à ideia do plano como projeto da cidade e remetia a uma ampla ordem de equipamentos públicos e de moradia que deveriam ser projetados pelos arquitetos. O projeto de Brasília elaborado pela equipe de Artigas, assim como a maioria dos projetos apresentados na ocasião do concurso eram baseados na Carta de Atenas. Essas diferentes perspectivas, uma tendo por referência o movimento moderno em arquitetura e outra o planejamento regional norte-americano dos anos 1920, leva a duas posições conflitantes, pelo menos sob dois aspectos: na relação do profissional com o Estado e no próprio papel do arquiteto no processo de planejamento.

Sobre a relação com o Estado, a proposta de Anhaia Mello era uma reforma administrativa do próprio Estado, em que o urbanismo seria dotado de ampla autonomia, respondendo unicamente ao executivo - ao prefeito. Como exemplificamos com o caso de Londrina, mas que também poderia ser recuperado em outros exemplos de obras públicas realizadas por Artigas, a sua posição, que coincidia com a de Le Corbusier, era de convencimento do Estado a adotar o urbanismo moderno e a arquitetura moderna na realização de obras públicas, desenvolvendo-se uma condição do arquiteto como comissionado do Estado. Isso, novamente, remete a diferenças em relação às matrizes de pensamento que alimentavam as duas visões, mas tem que ver também com a condição inerente a cada campo que são, afinal, distintos. Se o urbanismo é de ordem política, além de técnica, uma de suas metas é a de interferir diretamente na organização do Estado. A arquitetura, como atividade privada, só pode esperar ser contratada para a realização de grandes projetos.

Essa é uma questão particularmente delicada quando observamos a trajetória de Artigas e de muitos dos arquitetos atuantes naquele período, que formularam a crítica da arquitetura com base nos preceitos do PCB. Entretanto, sempre terminava-se em uma crítica da arquitetura a serviço das classes dominantes, problema que não encontrava saída, conforme já apontado por Amaral, Arantes e Medrano \& Recamán. No contexto de luta pela afirmação da categoria profissional, os arquitetos buscavam tornar-se classe dominante. Ao mesmo tempo, esperavam ser contratados pelo Estado para poder realizar projetos, preferencialmente no âmbito do plano, que cumprissem sua função social, não mais limitando a arquitetura à produção de algumas casas para a elite. Essa é a posição de Artigas em "Caminhos da Arquitetura Moderna”, quando defendeu que, até que a arquitetura fosse debatida nas fábricas e nos campos, os profissionais mantivessem "uma atitude crítica da realidade". "Atitude crítica" que redundou na transformação de sua obra em um "comentário crítico" acerca da cidade, como defendem Medrano \& Recamán (2014).

No que se refere ao papel do arquiteto no planejamento urbano, esse foi um limite para a aliança entre arquitetura e urbanismo na FAUUSP, como o episódio da proposta de regulamentação profissional revelou. Não interessava a Anhaia Mello defender o urbanismo como atribuição de arquitetos, algo que também não cabia em seu urbanismo multidiscpli- 
nar. Em resposta à proposta apresentada, o urbanista, como era de costume, deu legitimidade à sua posição apoiando-se em discursos que não eram os seus, fundamentando-se e nas resoluções de eventos realizados naquela época - o Seminário de Técnicos e Funcionários de Planejamento Urbano, realizado em Bogotá, o Congresso da UIA de Moscou. Nas resoluções desses eventos, defendia-se, respectivamente, que as equipes de profissionais atuantes em planificação urbana deveriam ser coordenadas por um especialista em urbanismo, não remetendo, portanto, à competência exclusiva do arquiteto, e a multidisciplinaridade das equipes que estudam problemas de urbanismo. Anhaia Mello concluiu afirmando que: "Esse conceito de exclusividade está hoje superado, porque o próprio urbanismo já superou a fase arquitetônica, dos arranjos urbanos, e percorre a estrada larga das considerações sociológicas e humanas na ordenação territorial" (Parecer de 11 de novembro de 1958). Se comparamos esse discurso com aquele apresentado à congregação da Escola Politécnica em 1946, em que afirmava que devia ser criada uma faculdade de arquitetura e urbanismo porque a arquitetura, com seus novos desígnios estabelecidos pelos novos tempos, abarcava toda a "ciência de planejar", a mudança é significativa.

Por outro lado, os arquitetos reivindicavam o urbanismo como atribuição profissional, num contexto de identidade e de fortalecimento da categoria. Devemos mais uma vez assinalar, que o "plano" defendido por Anhaia Mello e pelos arquitetos que propunham a separação do órgão de engenharia eram coisas distintas. Para esses, o plano era o desenho da cidade como suporte para a realização de edifícios modernos.

Portanto, acreditamos que arquitetura e urbanismo não resultaram na formação de um único campo profissional, nem na universidade, nem na cidade de São Paulo, conforme vimos procurando demonstrar. Entretanto, a união como estratégia traçada para a realização de um projeto em comum - separar-se da engenharia visando consolidar a hegemonia da arquitetura moderna e um campo autônomo de urbanismo, foi evidenciada em ambos os lados. Essa estratégia teve como uma componente importante a ideia do plano como interface entre os campos. Esta característica condicionou um pacto entre arquitetos e urbanistas com vistas à garantia de autonomia do campo, mas fora desse interesse específico em comum, predominava a separação naquilo que havia de distinto, a exemplo do ocorrido entre 1958 e 1959, quando o IAB apresentou uma proposta de regulamentação da profissão de arquiteto. Nesse sentido, pode-se considerar que os arquitetos modernos valeram-se da ideia de plano, assim como do urbanismo, até o ponto em que isso interessava à realização daquela estratégia. Do mesmo modo, Anhaia Mello defendeu a unidade entre os campos até o ponto em que isso não interferia em seus próprios interesses para o urbanismo. Todavia as investidas no sentido da idealização e execução de planos se mostraram historicamente ineficazes, dado que ao tratarem do "plano", arquitetura e urbanismo se referiam a coisas distintas. Assim, fica claro que o discurso da união dos campos, bem como a estratégia lançada para essa reunião, teve razão de ser até o momento em que se conquistou o objetivo comum a ambos os lados, qual seja, a separação da engenharia.

Por fim, devemos observar que, ainda que a fundação da FAUUSP não represente a constituição de um único campo de arquitetura e urbanismo, os objetivos pretendidos por essa aliança foram em grande medida bem-sucedidos. A separação da engenharia contribuiu, efetivamente, para a afirmação da arquitetura moderna como linguagem hegemônica em São Paulo, por um lado, e, por outro, para a constituição do urbanismo como disciplina autônoma. Nesse sentido, a existência de disputas e divergências que ainda não haviam sido 
assinaladas não diminui a importância das conquistas obtidas. Procuramos, assim, chamar a atenção para as repercussões da fundação da FAUUSP para os campos de urbanismo e de arquitetura em São Paulo, em um importante momento de institucionalização, para o qual a formação - o ensino - teve um papel central. 


\section{REFERÊNCIAS BIBLIOGRÁFICAS}




\section{Arquitetura e urbanismo modernos}

ARANTES, O. Urbanismo em fim de linha. São Paulo: Edusp, 1998.

O lugar da arquitetura depois dos modernos. São Paulo: Edusp, 2000.

BANHAM, R. Teoria e projeto na primeira idade da máquina. São Paulo: Perspectiva, 1975.

BARONE, A.C.C. Team 10: arquitetura como crítica. (Dissertação de Mestrado). São Paulo, FAUUSP, 2000.

. Ibirapuera: parque metropolitano. (Tese de Doutorado). São Paulo: FAUUSP, 2007.

BENEVOLO, L. História da Cidade. São Paulo: Perspectiva, 2007.

BRAGA, A.M.C. (Im)possíveis Brasilias, São Paulo: Alameda, 2011.

COLQUHOUN, A. 2004. Modernidade e tradição clássica. São Paulo, Cosac Naify.

GEDDES, P. Cidades em Evolução. Campinas: Papirus, 1994.

FRAMPTON, K. História crítica da arquitetura moderna. São Paulo: Martins Fontes, 1997.

FERRAZ, Geraldo. Warchavchik e a introdução da nova arquitetura no Brasil: 1925 a 1940. São Paulo: Ed. Masp, 1965

LIRA, J.T.C. Crítica Modernista e Urbanismo: Geraldo Ferraz em São Paulo, da Semana a Brasília. In: Encontro Nacional da Associação Nacional de Pós-Graduação e Pesquisa em Planejamento Urbano e Regional, XI, 2005. Anais do XI Enanpur. Salvador, Maio 2005.

Modernização Projetual e Urbanização em São Paulo: a atuação de Warchavchik entre 1932 e 1950. XII Encontro da Associação Nacional de Pós-Graduação e Pesquisa em Planejamento Urbano e Regional, Belém-PA, 2007. Anais do XII ENANPUR. Belém: Anpur, 2007.

LE CORBUSIER. Planejamento Urbano. São Paulo: Perspectiva, 1971.

Maneira de Pensar o Urbanismo. Maia: Publicações Europa-América, 1977.

Carta de Atenas. São Paulo: Edusp, 1993.

Urbanismo. São Paulo, Martins Fontes, 2000.

MORANCÉ, A; BADOVICI, J. L'oeuvre de Tony Garnier. Paris: Ed. Albert Morancé, [s.d].

PAWLOWSKI, C.K. Tony Garnier, pionnier de l'urbanisme du XXème siècle. Lyon: Les Créations du Pelican, 1993.

PEVSNER, N. As origens da arquitetura moderna e do design. São Paulo: Martins Fontes, 2001. Pioneiros do desenho moderno: de William Morris a Walter Gropius. São Paulo: Martins Fontes, 2002.

QUEIROZ, R.C. Projeto moderno e território americano: a arquitetura de uma nova paisagem, 2012. Disponível em:

http://www.docomomo.org.br/seminario\%208\%20pdfs/166.pdf

TOPALOV, C. La ville "congestionnée” - Acteurs e langage de la réforme urbaine a New York au début du XXème siècle. In: Genèses, 1, set. 1990, p. 86-111.

VIDLER, A. L'Acropole Moderne. In: Tony Garnier. L'oeuvre complète. Paris: Centre Georges Pompidou, 1990, p.71-79. 


\section{Campo Profissional de Arquitetura e Urbanismo}

ATIQUE, F. Arquitetando a "Boa Vizinhança": a sociedade urbana no Brasil e a recepção do mundo norte-americano, 1876-1945. (Tese de Doutorado). São Paulo: FAUUSP, 2007.

Articulações Profissionais: os Congressos Pan-americanos de Arquitetos e o amadurecimento de uma profissão no Brasil, 1920-1940. In: GOMES, M.A.A.F. (org.). Urbanismo na America do Sul: circulação de ideias e constituição do campo, 1920-1960. Salvador: EDUFBA, 2009, pp. 41-91.

DEDECCA, P.G. Sociabilidade, Crítica e Posição: o meio arquitetônico, as revistas especializadas e o debate moderno em São Paulo (1945-1965). (Dissertação de Mestrado). São Paulo: FAUUSP, 2012.

IAB. Prédio do IAB-SP em restauro. In: Boletim Informativo, 56, out/nov/dez 2006. Disponível em: http://www.iabsorg.br/boletim-56.pdf (acesso em 25/09/2014).

MORSE, R. De comunidade a metrópole: biografia de São Paulo. São Paulo: Ed. IV Centenário, 1954.

PINHEIRO, M.L.B. Lúcio Costa e a Escola Nacional de Belas Artes. In: 6. Seminário DOCOMOMO-Brasil, 2005, Niterói. Anais do 6 Seminário DOCOMOMO-Brasil, 2005.

RABELO, C. D. N. Arquitetos na cidade: espaços profissionais em expansão (Rio de Janeiro, 192535). (Tese de Doutorado). São Paulo: FAUUSP, 2011.

REIS FILHO, N. G. Campo da arquitetura e urbanismo. In: Cadernos de História de São Paulo, 1 (Os campos do conhecimento e o conhecimento da cidade), São Paulo: Museu Paulista da Universidade de São Paulo, 1992.

SAMPAIO, M.R.A.de. Christiano Stockler das Neves: uma atuação polêmica. In: Revista do Instituto de Estudos Brasileiros, 35, São Paulo: IEB, 1995, p.181-196.

SILVA, J.M. de C. O arquiteto e a produção da cidade: a experiência de Jacques Pillon em perspectiva (1930-1960). Tese de doutoramento. São Paulo: FAUUSP, 2010.

Da arqueologia portuguesa à arquitetura brasileira. In: Revista do IEB, 43, 2006, p. 69-98.

SINGER, P. Economia Política da Urbanização. São Paulo: Difel, 1985

UZEDA, H.C. de. O Curso de Arquitetura da Escola Nacional de Belas Artes e processo de modernização do centro da cidade do Rio de Janeiro no início do século XX. In: 19Qð20, Rio de Janeiro, jan. 2010. Disponível em: http://www.dezenovevinte.net/arte\%20decorativa/ ad_huzeda.htm

\section{FAUUSP}

ALBUQUERQUE, R.P. Uma escola de arquitetura - FAUUSP: edifícios e ensino. Dissertação de Mestrado. São Paulo: FAUUSP, 2004.

AMARAL, A. A preocupação social na arte brasileira (1930-1970). (Tese de livre docência). São Paulo: FAUUSP, 1983

História da Arte na formação do arquiteto. In: Sinopses, edição especial, São Paulo: FAUUSP, 1993, pp. 83-84.

DOMSCHKE, V.L. O ensino da arquitetura e a construção da modernidade. (Tese de Doutorado). São Paulo: FAUUSP, 2007 
DUARTE, H. de Q. Roteiro do Planejamento da Cidade Universitária Armando Salles de Oliveira. São Paulo: RUSP, 1956.

Contribuição ao ensino da arquitetura. São Paulo: FAUUSP, 1954 (mimeo).

Escolas-classe e Escolas-parque: uma experiência educacional. São Paulo: FAUUSP, 2009 (2 $2^{\text {a }}$ d.).

Considerações sobre a competência dos órgãos da FAU. São Paulo: FAUUSP, 1972 (mimeo).

Teses acadêmicas: considerações. São Paulo: FAUUSP, 1972 (mimeo).

FAGGIN, C. O Ateliê na formação do arquiteto: uma análise crítica do documento apresentado por Carlos Millán na FAUUSP em 1962. In: Sinopses, edição especial, São Paulo: FAUUSP, 1993, pp. 130-132.

KATINSKY, J.R. Desenho Industrial. In ZANINE, Walter (org.). História Geral da arte no Brasil. São Paulo, Instituto Walter Moreira Salles, 1983, v. 2. pp. 933-948.

Considerações sobre o curso de pós-graduação da FAUUSP - 1973-1999. In: Revista Pós, São Paulo: FAUUSP, n. 8, 2000, pp.90-99.

NARUTO, M. Repensar a formação do arquiteto. (Tese de Doutorado). São Paulo: FAUUSP, 2006.

NIEMEYER, L. Design no Brasil: origens e instalação. Rio de Janeiro: 2AB, 1998.

PEREIRA, J.A. Desenho Industrial e Arquitetura no ensino da FAUUSP (1948-1968). Tese de doutoramento. São Carlos: EESC-USP, 2009.

SEGAWA, H. Arquiteturas no Brasil 1900-1990. São Paulo: Edusp,1997.

SODRÉ, J.C. Arquitetura e Viagens de Formação pelo Brasil (1938-1962). Dissertação de Mestrado. São Paulo: FAUUSP, 2010.

Trabalho Programado 3 In: Viagens pelo Brasil a partir da FAUUSP, 1948-1962 (Memorial de Qualificação para Dissertação de Mestrado na FAUUSP). São Paulo, 2009 (Não publicado).

SIQUEIRA, R.M. FAUUSP, 1962: a implementação do Grupo de Disciplinas de Desenho Industrial no Curso de Arquitetura e Urbanismo. In: CONGRESSO INTERNACIONAL DE PESQUISA EM DESIGN, V, 2009, Bauru. Anais do 50 Congresso Internacional de pesquisa em Design. Bauru: Unesp/Anpedesign, 2009.

ZANINI, W. História Geral da Arte no Brasil. v.1, São Paulo: Instituto Moreira Salles, 1983.

\section{Luiz Inácio Romeiro de Anhaia Mello}

ARASAWA, C.H. A árvore do urbanismo de Luiz de Anhaia Mello. São Paulo: FFLCH. Dissertação de Mestrado. 1999.

Entre o passado e o futuro: engenheiros, arquitetos e urbanistas em São Paulo (1870-1930). In: VII Seminário de História da Cidade e do Urbanismo. Anais do VII SHCU, 2002. Disponivel em: http://www.anpur.org.br/revista/rbeur/index.php/shcu/article/ view/852

BRESCIANI, M.S. As múltiplas linguagens do urbanismo de Anhaia Mello: técnica, estética e política. In: Faria, R.; Cerasoli, J. (Org.). Urbanistas e Urbanismo no Brasil. Entre trajetórias e biografias. São Paulo: Alameda/CAPES/CNPq, 2014, v. 1, p. 231-269.

FELDMAN, S. Planejamento e Zoneamento. São Paulo: Edusp, 2005. 
Os anos 30 e a difusão do urbanismo americano. In: Seminário de História da Cidade e do Urbanismo, VI, 2000, Natal. Anais do VI SHCU. Natal: PPGAU-UFRN, 2012 FICHER, S. O ensino da construção no domínio da arquitetura. Projeto, São Paulo, n.112, p. 129-130, 1988.

Os arquitetos da Poli: Ensino e profissão em São Paulo. São Paulo: Edusp, 2005.

MEYER, Regina .M.P. Metrópole e urbanismo: São Paulo anos 50. (Tese de Doutorado). São Paulo: FAUUSP, 1991.

TIMOTEO, J.P. A cidade de São Paulo em "escala humana": Luiz de Anhaia Mello e sua proposta de recreio ativo e organizado.(Mestrado). Campinas: IFCH-Unicamp, 2008.

Luiz de Anhaia Mello: um pensamento constituído por "diversos mundos que se tocam e interpenetram”. In: Urbana, n.2, Campinas: CIEC-Unicamp, 2007 [online]. Disponível em: http://www.ifch.unicamp.br/ojs/index.php/urbana/article/view/1053 (acesso em 10/12/2014).

\section{João Batista Vilanova Artigas}

ARANTES, P.F. Arquitetura Nova: Sérgio Ferro, Flávio Império e Rodrigo Lefèvre, de Artigas aos mutirões. São Paulo: Ed. 34, 2002.

BUZZAR, M. A. João Batista Vilanova Artigas: elementos para a compreensão de um caminho da arquitetura brasileira. (Tese de Doutorado). São Carlos: EESC-USP, 1996.

CUNHA, G.R. Uma análise da produção de Vilanova Artigas entre os anos de 1967 a 1976. (Dissertação de Mestrado). São Carlos: EESC-USP, 2009.

FERRAZ, M. (coord.). Vilanova Artigas. São Paulo: Instituto Lina Bo e P.M.Bardi, 1997.

GABRIEL, M. F. Vilanova Artigas: uma poéica traduzida. (Dissertação de Mestrado). São Carlos: EESC-USP, 2003.

IRIGOYEN, A. Wright e Artigas: duas viagens. São Paulo: Ateliê Editorial, 2002.

IWAMIZU, C.S. A Estação Rodoviária de Jaú e a dimensão urbana da arquitetura. (Dissertação de Mestrado). São Paulo: FAUUSP, 2008.

MEDRANO, L.; RECAMÁN, L. Duas Casas de Artigas: cidade adjetiva. In: Pós. Revista do Programa de Pós-Graduação em Arquitetura e Urbanismo da FAUUSP, 2012.

Vilanova Artigas - Habitação e cidade na modernização brasileira. Campinas: Editora Unicamp, 2014.

PETROSINO, M.M. João Batista Vilanova Atigas - residências unifamiliares: a produção arquitetônica de 1937 a 1981. (Dissertação de Mestrado).São Paulo: FAUUSP, 2009.

SUZUKI, J.H. Vilanova Artigas e Carlos Cascaldi em Londrina: uma contribuição ao estudo da arquitetura moderna no Estado do Paraná. (Dissertação de Mestrado). São Paulo: FAUUSP, 2000 .

THOMAZ, D. E. Um olhar sobre Vilanova Artigas e sua contribuição à arquitetura brasileira. (Dissertação de Mestrado). São Paulo: FAUUSP, 1997. Vilanova Artigas: A liberdade na inversão do olhar. (Tese de Doutorado). São Paulo: FAUUSP, 2005. 


\section{Ramos de Azevedo}

CARVALHO, M.C.W de. Arquitetura de Ramos de Azevedo. Tese de Doutorado. São Paulo: FAUUSP, 1996.

Ramos de Azevedo. São Paulo: Edusp, 2000.

LEMOS, C.A.C. Ramos de Azevedo e seu escritório. São Paulo: Pini, 1993.

\section{Corpo docente da FAUUSP}

ABREU, I.R.N. Convenio Escolar: utopia construída. (Dissertação de Mestrado). São Paulo: FAUUSP, 2007.

ALMEIDA, E. \& TEIXEIRA, K. Jon Maitrejean: a casa como mote de reflexão e experimentação. Arquitextos, 102.01, nov. 2008. Disponível em: http://www.vitruvius.com.br/revistas/ read/arquitextos/09.102/92 (acesso em 04/12/2014).

ANELLI, R.L.S. Arquitetura e Cidade na obra de Rino Levi. (Tese de Doutorado). São Paulo: FAUUSP, 1998.

AYOUB, H.S.A. Abrahão Sanovicz: o projeto como pesquisa. (Tese de Doutorado). São Paulo: FAUUSP, 2005.

BRUNA, P. J.V. Roberto Cerqueira César (1917-2003). In: Projeto Design, 282, São Paulo: Arco, 2003, p.18.

CONSTANTINO, R. A. A obra de Abelardo de Souza. Dissertação de Mestrado. São Paulo: FAUUSP, 2004.

FERRAZ, G. Novos rumos da arquitetura brasileira: Abelardo de Souza. In: Habitat, 39, fev. 1957, p. 2-21.

MALERONKA, C. Caetano Fraccaroli: arte, reflexão e ensino. (Iniciação Científica). São Paulo: FAUUSP, 2000.

MATERA, S. Carlos Millan: um estudo sobre a produção em arquitetura. (Dissertação de Mestrado). São Paulo: FAUUSP, 2005.

MONDENESE FILHO, E. Entre linhas e curvas: a teoria e a prática na obra de Zenon Lotufo. Dissertação de Mestrado. São Paulo: FAUUSP, 2008

MONTENEGRO FILHO, R. A pré-fabricação na trajetória de Eduardo Kneese de Mello. (Tese de Doutorado). São Paulo: FAUUSP, 2012

QUINTANILHA, R.; JUNQUEIRA, M.C. Duas cidades de Joaquim Guedes: temas urbanos nos projetos de Brasília, 1957, e Caraíba, 1976. In: Urbana, v.5, n.7, Campinas, CIEC/Unicamp, 2013, p.98-108.

SANT'ANNA JR., A.C. Arquitetura Paulista: um outro caminho. In: AU, 97, agosto 2001. Disponível em: http://au.pini.com.br/arquitetura-urbanismo/97/arquitetura-paulista-um-outro-caminho-23744-1.aspx (acesso em 04/12/2014).

SANTOS, L.C. Arquitetura paulista em torno de 1930-40. (Dissertação de Mestrado). São Paulo: FAUUSP, 1985.

SEGAWA, H.. Duarte, Hélio [Online]. Disponível em: http://citrus.uspnet.usp.br/architectus/verbete.php?cd_verbete=8. Ultima atualização em 24/05/2010.

TAKIYA, A. Edif 60 anos de arquitetura pública. (Dissertação de Mestrado). São Paulo: FAUUSP, 2009. 


\section{Documentos consultados}

\section{Campo profissional}

IAB. Primeiro Congresso Brasileiro de Arquitetos. São Paulo: IAB-SP, 1945.

III Congresso Brasileiro de Arquitetos. Belo Horizonte: IAB-MG, 1953.

Anais do IV Congresso Brasileiros de Arquitetos.São Paulo: IAB-SP, 1954.

Anais do VI Congresso Brasileiros de Arquitetos. Salvador, IAB-BA, 1966.

I Congresso Brasileiro de Arquitetos. In: Acrópole, 81-82, São Paulo, jan-fev 1945, p.269-278. UIA. Anais do III Congresso Internacional de Arquitetos. Lisboa: UIA, 1953

\section{FAUUSP}

ARTIGAS, J.B.V. Contribuição para o Relatório sobre Ensino de Arquitetura UIA-UNESCO [1974]. In: Sinopses, edição especial, São Paulo: FAUUSP, 1993, pp.133-139.

BIRKHOLZ, L.B; NOGUEIRA, B.C. A FAUUSP, sua criação e funcionamento na Vila Penteado. In: Sinopses, edição especial, São Paulo: FAUUSP, 1993, pp. 5-11.

BIRKHOLZ; L.B., RONCA, J.L.; ZAHN, C.E. Ensino do Planejamento Territorial no Grupo de Disciplinas de Planejamento do Departamento de Projeto da FAUUSP, de 1948 a 1992. In: Sinopses, edição especial, São Paulo: FAUUSP, 1993, pp.31-33.

CORONA, E. Relatório da Comissão de Exercício Profissional da UIA. São Paulo: GFAU, 1960. GFAU. Textos sobre ensino de arquitetura: Mario Wagner Vieira da Cunha, Luis Saia, João Batista Vilanova Artigas, Lina Bo Bardi. São Paulo: Gfau, 1956.

Faculdade de arquitetura e urbanismo. São Paulo: Gfau, 1963

FAUUSP. Programas de disciplinas. São Paulo: FAUUSP, 1953-1969. Abaixo-assinado pela nomeação do diretor da FAUUSP (manuscrito), 1961. Disponível em: http://www.dearquiteturas.com/2012_04_01_archive.html (acesso em 18/10/2013). O primeiro fórum de debates (de 12 a 14 de novembro de 1963). São Paulo: FAUUSP, 1963a.

Relatório de Atividades de 1962. São Paulo: FAUUSP, 1963b.

Fórum de debates 1968: documentos e relatórios das comissões e subcomissões. São Paulo:

FAUUSP, 1968.

I Livro de Atas da Congregação da FAUUSP (1968-1969).

Fórum 1969/ Relatório Museu FAU. São Paulo: FAUUSP, 1969.

I Encontro de ensino de Projeto. Depto. de Projeto. São Paulo: FAUUSP, 1975.

GRINOVER, L. Entrevista ao Prof. Dr. Marcos da Costa da Braga e a Renata Monteiro Siqueira. em 22/10/2008.

MILLAN, C. (relator). O ateliê na formação do arquiteto/ 1962/ Relatório. São Paulo: FAUUSP, 1962.

MOTTA, F. Subsídios para o relatório sobre ensino de arquitetura UIA-UNESCO [1974]. In: Sinopses, edição especial, São Paulo: FAUUSP, 1993, pp. 138-143. 
O histórico brasileiro e a Faculdade de Arquitetura e Urbanismo da Universidade de São Paulo. São Paulo: FAUUSP, [s.d.]

PRADO, L.C. do. Tendências para o ensino de arquitetura e urbanismo. Aula inaugural de 1964. (mimeo).

\section{Luiz Inácio Romeiro de Anhaia Mello}

ANHAIA MELLO, L.I.R. de. A cidade, problema de governo. In: Boletim do Instituto de Engenharia. São Paulo, n.43, dez. 1928.

_. Problemas de urbanismo: bases para a resolução do problema técnico. São Paulo: IE, 1929a.

Urbanismo: o recreio ativo e organizado das cidades modernas. In: Boletim do Instituto de Engenharia. São Paulo, n.47, abr. 1929b.

Novos subsídios para a Regulamentação dos Serviços de Utilidade Publica. In: Boletim do Instituto de Engenharia, vol. XX. n 104. Pág. 3 - 12. São Paulo: julho de 1934.

. Um Programa de Habitação para os Estados Unidos. In: Revista Politécnica. São Paulo, n.121, jan./mar. 1936, p.162.

Problema econômico dos serviços de utilidade pública. São Paulo: PMSP, 1940.

. A Cidade, Base Material de Relações Sociais, Sociologia Urbana, Ecologia Humana e o Plano de Londres. In: Engenharia. São Paulo, n.31, mar. 1945.

A Cidade Jardim. In: Digesto Econômico. São Paulo, n.36, nov. 1947.

Urbanismo, esse desconhecido. São Paulo: SAC, 1952 (mimeo).

O plano regional de São Paulo: uma contribuição da universidade para o estudo de um código de ocupação lícita do solo. São Paulo: FAUUSP, 1954 (mimeo).

Urbanismo positivo e urbanismo negativo: as modernas cidades inglesas. São Paulo: FAUUSP, 1955a.

—. Visão do futuro e realidade do presente. In: Habitat. São Paulo, n.21, mar./abr. $1955 \mathrm{~b}$.

_. Curso de urbanismo: elementos de composição regional. São Paulo: Grêmio Politécnico, 1961.

CPEU Organização e funções da Comissão do Plano Diretor nos municípios. São Paulo: FAUUSP, 1958a.

Plano Diretor de Águas da Prata. São Paulo: FAUUSP, 1958 b.

Plano Diretor de Socorro. São Paulo: FAUUSP, 1959.

Boletim Informativo para o Planejamento do Litoral Norte, 01, São Paulo: FAUUSP, 1960a.

Boletim Informativo para o Planejamento do Litoral Norte, 02, São Paulo: FAUUSP, 1960b.

Boletim Informativo para o Planejamento do Litoral Norte, 03, São Paulo: FAUUSP, 1960c.

Boletim Informativo para o Planejamento do Litoral Norte, 04, São Paulo: FAUUSP, 1960d.

Pesquisa do Litoral Norte: Relatório Preliminar - Aspectos Físicos da Ação Humana, São Paulo: FAUUSP, 1960e. 
Pesquisa do Litoral Norte: Relatório Preliminar - Aspectos Historicos. São Paulo: FAUUSP, 1960f. Pesquisa do Litoral Norte: Relatório Preliminar - Aspectos Econômicos. São Paulo: FAUUSP, 1960g. Pesquisa do Litoral Norte: Relatório Preliminar - Aspectos Administrativo. São Paulo: FAUUSP, $1960 \mathrm{~h}$. Plano Preliminar de Itanhaém. São Paulo: FAUUSP, 1961.

Elementos para o planejamento territorial dos municípios. Boletim $n^{\circ}$ 01. São Paulo: FAUUSP, 1963a.

O Centro de Pesquisa e Estudos Urbanísticos e os Convênios Realizados para Planejamento das Estâncias de São Paulo. Boletim n 7. São Paulo: FAUUSP,1963b. Conselho de Desenvolvimento, Escritório Técnico de Planejamento e Departamento de Obras. Boletim $n^{\circ}$ 10.São Paulo: FAUUSP, 1963c. Planejamento Territorial do Município de São José dos Campos. São Paulo: FAUUSP, 1964a. Zoneamento: classificação dos usos do solo urbano. Boletim $n^{\circ}$ 6. São Paulo: FAUUSP, 1964b. Estância climática de Santa Rita do Passa Quatro: Relatório Justificativo 1958/1959. São Paulo: FAUUSP, 1964c. Plano Diretor de Pinhal. São Paulo: FAUUSP, 1965. Plano Diretor da Estância de Amparo. São Paulo: FAUUSP, 1966. Plano Diretor de Bauru. São Paulo: FAUUSP, 1967. Plano Diretor de São José do Rio Pardo. São Paulo: FAUUSP, 1968. Plano Diretor de Aparecida. São Paulo: FAUUSP, 1969.

ESCOLA POLITECNICA. Livro de Atas da Congregação (XIV-XVIII), 1945-1961. .Pasta Funcional de Anhaia Mello. 1918-1961.

\section{João Batista Vilanova Artigas}

ARTIGAS, J.B.V. Contribuição para o Relatório sobre Ensino de Arquitetura UIA-UNESCO [1974]. In: Sinopses, edição especial, São Paulo: FAUUSP, 1993, pp.133-139.

ARTIGAS, J.B.V. Artigas por Artigas. [s.1.]: Iabice, 1985.

Depoimento a Sylvia Ficher. 1982 (datilografado)

Caminhos da Arquitetura. São Paulo: Cosac \& Naify, 2004.

Vilanova Artigas Arquitecto: 11 textos e uma entrevistas.Almada: Casa da Cerca, 2001.

Carta a Oswaldo Corrêa Gonçalves, 27/12/1946, disponível em: http://www.dearquiteturas.com/2012/03/FAUUSP-50-anos-da-reforma-de-ensino-de.html (acesso em agosto/2013).

Desenho Industrial. São Paulo: FAUUSP (Pasta Funcional de Professor), 1962/63 (transcrição).

Artigas, J.B.V, Cascaldi, C., Cunha, M.W.V., Almeida, P.C. Plano piloto nº 01 - $5^{\circ}$ Prêmio. In: Módulo, edição especial sobre o concurso de Brasília, julho, 1957.

Revista Módulo, Edição Especial sobre Artigas. 1985.

ESCOLA POLITÉCNICA. Pasta Funcional de J.B. Vilanova Artigas. 1940-1969. 


\section{APÊNDICES}




\title{
APÊNDICE A - ESTRUTURA CURRICULAR DA FAUUSP E CORPO DOCENTE
}

\author{
Estrutura curricular e corpo docente responsavel (1948-1955)*
}

\begin{tabular}{|c|c|c|c|c|c|}
\hline Cadeira & 1948 & 1949 & 1950 & 1951 & 1952 \\
\hline Matemática Superior & $*$ & $*$ & $*$ & $*$ & $*$ \\
\hline Geometria Descritiva e Aplicações & $*$ & $*$ & $*$ & $*$ & $*$ \\
\hline Mecânica Racional & $*$ & $*$ & $*$ & $*$ & $*$ \\
\hline $\begin{array}{l}\text { Topografia, Elementos de } \\
\text { Astronomia de Posição }\end{array}$ & $*$ & $*$ & $*$ & $*$ & $*$ \\
\hline $\begin{array}{l}\text { Resistência dos Materiais e } \\
\text { Estabilidade das Construções }\end{array}$ & $*$ & $*$ & $*$ & $*$ & $*$ \\
\hline Materiais de Construção & $*$ & $*$ & $*$ & $*$ & $*$ \\
\hline $\begin{array}{l}\text { Hidráulica; Hidráulica Urbana e } \\
\text { Saneamento. }\end{array}$ & $*$ & $*$ & $*$ & $*$ & $*$ \\
\hline $\begin{array}{l}\text { Construções Civis (Organização do } \\
\text { trabalho e Pratica profissional; } \\
\text { Higiene das Habitações ) }\end{array}$ & $*$ & $*$ & $*$ & $*$ & $*$ \\
\hline Concreto Simples e Armado & $*$ & $*$ & $*$ & $*$ & $*$ \\
\hline $\begin{array}{l}\text { Elementos de Mecânica } \\
\text { dos Solos. Fundações }\end{array}$ & $*$ & $*$ & $*$ & $*$ & $*$ \\
\hline Grandes Estruturas & $*$ & $*$ & $*$ & $*$ & $*$ \\
\hline $\begin{array}{l}\text { Economia Política e Estatística aplicada, } \\
\text { Organizações Administrativas }\end{array}$ & $*$ & $*$ & $*$ & $*$ & $*$ \\
\hline Física Aplicada & $*$ & $*$ & $*$ & $*$ & $*$ \\
\hline Arquitetura Analítica & $*$ & $*$ & $*$ & $*$ & $*$ \\
\hline Teoria da Arquitetura & $*$ & $*$ & $*$ & $*$ & $*$ \\
\hline $\begin{array}{l}\text { Composição Arquitetônica - } \\
\text { Pequenas Composições }\end{array}$ & $*$ & $*$ & $*$ & $*$ & $*$ \\
\hline $\begin{array}{l}\text { Composição Arquitetônica - } \\
\text { Pequenas Composições (II) }\end{array}$ & $*$ & $*$ & $*$ & $*$ & $*$ \\
\hline $\begin{array}{l}\text { Composição Arquitetônica - } \\
\text { Grandes Composições }\end{array}$ & $*$ & $*$ & $*$ & $*$ & $*$ \\
\hline $\begin{array}{l}\text { Composição Arquitetônica - } \\
\text { Grandes Composições (II) }\end{array}$ & $*$ & $*$ & $*$ & $*$ & $*$ \\
\hline Arquitetura no Brasil & $*$ & $*$ & $*$ & $*$ & $*$ \\
\hline Urbanismo & $*$ & $*$ & $*$ & $*$ & $*$ \\
\hline Arquitetura Paisagista & $*$ & $*$ & $*$ & $*$ & $*$ \\
\hline História da Arte e Estética & $*$ & $*$ & $*$ & $*$ & $*$ \\
\hline Nomografia & $*$ & $*$ & $*$ & $*$ & $*$ \\
\hline Legislação e Contabilidade & $*$ & $*$ & $*$ & $*$ & $*$ \\
\hline Desenho artístico & $*$ & $*$ & $*$ & $*$ & $*$ \\
\hline Desenho Artístico I & $*$ & $*$ & $*$ & $*$ & $*$ \\
\hline Composição decorativa & $*$ & $*$ & $*$ & $*$ & $*$ \\
\hline Plástica. & $*$ & $*$ & $*$ & $*$ & $*$ \\
\hline Plástica $2^{\circ}$ ano & $*$ & $*$ & $*$ & $*$ & $*$ \\
\hline Plástica $3^{\circ}$ ano & $*$ & $*$ & $*$ & $*$ & $*$ \\
\hline Plástica $4^{\circ}$ ano & $*$ & $*$ & $*$ & $*$ & $*$ \\
\hline
\end{tabular}

* Estrutura Curricular baseada na lei 104/1948. Corpo docente conforme consta no programa de disciplinas. Apenas os programas de 1953 puderam ser consultados. 
Cadeira

1953

1954

Matemática Superior

José Octávio Monteiro de Camargo

Geometria Descritiva e Aplicações

Pedro Moacyr do Amaral Cruz

Mecânica Racional

Topografia, Elementos de

João Augusto Breves Filho

Astronomia de Posição

Resistência dos Materiais e

Henrique Jorge Guedes

$\begin{array}{ll}* & * \\ * & *\end{array}$

Estabilidade das Construções

Telemaco Hippolito de Macedo van

Longendonck

Materiais de Construção

Hidráulica; Hidráulica Urbana e

Saneamento.

Construções Civis (Organização do

trabalho e Pratica profissional;

Higiene das Habitações )

Concreto Simples e Armado

Elementos de Mecânica

dos Solos. Fundações

Grandes Estruturas

Economia Política e Estatística aplicada,

Organizações Administrativas

Física Aplicada

Arquitetura Analítica

Teoria da Arquitetura

Composição Arquitetônica -

Pequenas Composições

Composição Arquitetônica -

Pequenas Composições (II)

Composição Arquitetônica -

Grandes Composições

Composição Arquitetônica -

Grandes Composições (II)

Arquitetura no Brasil

Urbanismo

Arquitetura Paisagista

História da Arte e Estética

Nomografia

Legislação e Contabilidade

Desenho artístico

Desenho Artístico I

Composição decorativa

Plástica.

Plástica $2^{\circ}$ ano

Plástica $3^{\circ}$ ano

Plástica $4^{\circ}$ ano
Ary Frederico Torres

Lysandro Mello Pereira da Silva

Ariosto Mila

Fernando José de Oliveira Escorel

Odair Grillo

Pedro Bento José Gravina

Carlos Alberto Vanzolini

Luiz Cintra do Prado

Bruno Simões Magro

Miguel Badra Júnior

Zenon Lotufo

João Batista Vilanova Artigas

Hélio de Queiroz Duarte/ José Vicente

Vicari

Elisário da Cunha Bahiano

Carlos Alberto Gomes Cardim Filho

Luiz Ignácio Romeiro de Anhaia Mello

Roberto Coelho Cardozo

Lourival Gomes Machado

Eurico Cerruti

Americo Oswaldo Campiglia

Archimedes Dutra

Vera Helena Amaral

José Maria da Silva Neves

Caetano Fraccarolli

Vicente Laroca

Bassano Vaccarini

Alfredo Oliani

$\begin{array}{ll}* & * \\ * & * \\ * & *\end{array}$

$* \quad *$

$*$

$\begin{array}{ll}* & * \\ * & *\end{array}$

*

*

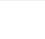


Estrutura curricular e corpo docente responsavel (1956-1962)*

\begin{tabular}{|c|c|c|c|c|c|c|c|}
\hline Cadeira & 1956 & 1957 & 1958 & 1959 & 1960 & 1961 & 1962 \\
\hline $\begin{array}{l}\text { Cálculo Diferencial e Integral. Geometria } \\
\text { Analítica. Nomografia }\end{array}$ & $\mathrm{s} / \mathrm{n}$ & \multicolumn{6}{|c|}{ José Octávio Monteiro de Camargo } \\
\hline Geometria Descritiva e Aplicações & $\mathrm{s} / \mathrm{n}$ & $\mathrm{s} / \mathrm{n}$ & \multicolumn{5}{|c|}{ Pedro Moacyr do Amaral Cruz } \\
\hline Mecânica & $\mathrm{s} / \mathrm{n}$ & $*$ & \multicolumn{5}{|c|}{ João Augusto Breves Filho } \\
\hline Física Geral e Aplicada & $\mathrm{s} / \mathrm{n}$ & \multicolumn{6}{|c|}{ Luiz Cintra do Prado } \\
\hline Materiais de Construção & $\mathrm{s} / \mathrm{n}$ & $*$ & \multicolumn{5}{|c|}{ Fernando José de Oliveira Escorel } \\
\hline $\begin{array}{l}\text { Resistência dos Materiais. Estabilidade } \\
\text { das Construções. }\end{array}$ & $\mathrm{s} / \mathrm{n}$ & \multicolumn{6}{|c|}{ Telemaco Hippolito de Macedo van Langendonck } \\
\hline $\begin{array}{l}\text { Estruturas Correntes de Madeira Metálicas e } \\
\text { de Concreto Simples e Armado }\end{array}$ & $\mathrm{s} / \mathrm{n}$ & \multicolumn{6}{|c|}{ José Carlos de Figueiredo Ferraz } \\
\hline Grandes Estruturas & $\mathrm{s} / \mathrm{n}$ & \multicolumn{6}{|c|}{ Pedro Bento José Gravina } \\
\hline $\begin{array}{l}\text { Técnica das Construções. Organização } \\
\text { dos Trabalhos e Prática Profissional. } \\
\text { Higiene dos Edifícios. Noções de Mecânica } \\
\text { dos Solos. Fundações }\end{array}$ & $\mathrm{s} / \mathrm{n}$ & \multicolumn{6}{|c|}{ Ariosto Mila } \\
\hline $\begin{array}{l}\text { Hidráulica. Hidráulica Urbana } \\
\text { e Saneamento }\end{array}$ & $\mathrm{s} / \mathrm{n}$ & $\begin{array}{l}\text { Lysandro } \\
\text { Mello Pereira } \\
\text { da Silva }\end{array}$ & \multicolumn{5}{|c|}{ Lucas Nogueira Garcez } \\
\hline $\begin{array}{l}\text { Topografia. Elementos de } \\
\text { Astronomia de Posição }\end{array}$ & $\mathrm{s} / \mathrm{n}$ & $\begin{array}{l}\text { Henrique } \\
\text { Jorge } \\
\text { Guedes }\end{array}$ & \multicolumn{5}{|c|}{ Paulo Ferraz de Mesquita } \\
\hline $\begin{array}{l}\text { Noções de Economia Política. Estatística } \\
\text { Aplicada. Organização Administrativa. } \\
\text { Legislação e Contabilidade Específica }\end{array}$ & $\mathrm{s} / \mathrm{n}$ & \multicolumn{5}{|c|}{ Mário Wagner Vieira da Cunha } & $\mathrm{s} / \mathrm{n}$ \\
\hline Arquitetura Analítica & $\mathrm{s} / \mathrm{n}$ & \multicolumn{6}{|c|}{ Enoch da Rocha Lima } \\
\hline Teoria da Arquitetura & $\mathrm{s} / \mathrm{n}$ & \multicolumn{6}{|c|}{ Eduardo Corona } \\
\hline História da Arte. Estética & $\mathrm{s} / \mathrm{n}$ & \multicolumn{6}{|c|}{ Flávio Motta } \\
\hline $\begin{array}{l}\text { Composição de Arquitetura Pequenas } \\
\text { Composições I, Desenho Arquitetônico, } \\
\text { Plástica I }\end{array}$ & $\mathrm{s} / \mathrm{n}$ & $\begin{array}{l}\text { Zenon } \\
\text { Lotufo }\end{array}$ & \multicolumn{5}{|c|}{ Hélio de Queiroz Duarte } \\
\hline $\begin{array}{l}\text { Composição de Arquitetura Pequenas } \\
\text { Composições II, Plástica II }\end{array}$ & $\mathrm{s} / \mathrm{n}$ & \multicolumn{6}{|c|}{ Abelardo Riedy de Souza } \\
\hline $\begin{array}{l}\text { Composição de Arquitetura Grandes } \\
\text { Composições I, Plástica III }\end{array}$ & $\mathrm{s} / \mathrm{n}$ & $\begin{array}{l}\text { Hélio de } \\
\text { Queiroz } \\
\text { Duarte }\end{array}$ & \multicolumn{5}{|c|}{ Roberto Cerqueira César } \\
\hline $\begin{array}{l}\text { Composição de Arquitetura. } \\
\text { Grandes Composições II }\end{array}$ & $\mathrm{s} / \mathrm{n}$ & \multicolumn{3}{|c|}{ Rino Levi } & $*$ & \multicolumn{2}{|c|}{$\begin{array}{l}\text { João Batista } \\
\text { Vilanova Artigas }\end{array}$} \\
\hline Arquitetura no Brasil & $\mathrm{s} / \mathrm{n}$ & \multicolumn{6}{|c|}{ Eduardo Augusto Kneese de Mello } \\
\hline Desenho Artístico & $\mathrm{s} / \mathrm{n}$ & \multicolumn{6}{|c|}{ Ernest Robert de Carvalho Mange } \\
\hline Composição Decorativa & $\mathrm{s} / \mathrm{n}$ & \multicolumn{5}{|c|}{ José Maria da Silva Neves } & \\
\hline Urbanismo & $\mathrm{s} / \mathrm{n}$ & \multicolumn{5}{|c|}{ Anhaia Mello } & $\begin{array}{l}\text { Lauro B. } \\
\text { Birkholz }\end{array}$ \\
\hline Arquitetura Paisagística & $\mathrm{s} / \mathrm{n}$ & \multicolumn{5}{|c|}{ Roberto Coelho Cardozo } & \\
\hline Matéria Legal Legislação. Ética Profissional. & * & $*$ & $*$ & $*$ & $*$ & $*$ & $*$ \\
\hline
\end{tabular}

\footnotetext{
* Estrutura Curricular baseada no decreto 3.233/1955. s/n - programa sem identificação do docente;

* - Programa não acessado
} 
Estrutura curricular e corpo docente responsavel (1963-1968)*

\begin{tabular}{|c|c|c|c|c|c|}
\hline Cadeira & 1963 & 1964 & 1965 & 1966 & 1967 \\
\hline $\begin{array}{l}\text { Cálculo Diferencial e Integral. Geometria } \\
\text { Analítica. Nomografia }\end{array}$ & $\begin{array}{l}\text { Domingos } \\
\text { Pizanelli }\end{array}$ & $*$ & \multicolumn{3}{|c|}{ Domingos Pizanelli } \\
\hline Geometria Descritiva e Aplicações & Pedro M. A. Cruz & $*$ & \multicolumn{3}{|c|}{ Pedro Moacyr do Amaral Cruz } \\
\hline Mecânica & João A. Breves Filho & $*$ & \multicolumn{3}{|c|}{ João Augusto Breves Filho } \\
\hline $\begin{array}{l}\text { Topografia. Elementos de } \\
\text { Astronomia de Posição }\end{array}$ & $\begin{array}{l}\text { Paulo Ferraz } \\
\text { de Mesquita }\end{array}$ & $*$ & \multicolumn{3}{|c|}{ Paulo Ferraz de Mesquita } \\
\hline Física Geral e Aplicada & Luiz Cintra do Prado & $*$ & \multicolumn{3}{|c|}{ Luiz Cintra do Prado } \\
\hline Construção I & Ariosto Mila & $*$ & \multicolumn{3}{|c|}{ Ariosto Mila } \\
\hline $\begin{array}{l}\text { Resistência dos Materiais e } \\
\text { Estabilidade das Construções. }\end{array}$ & $\begin{array}{l}\text { Telemaco Hippolito } \\
\text { de Macedo van } \\
\text { Longendonck }\end{array}$ & $*$ & \multicolumn{3}{|c|}{$\begin{array}{l}\text { Telemaco Hippolito de Macedo van } \\
\text { Longendonck }\end{array}$} \\
\hline Hidráulica e Saneamento & Lucas N. Garcez & $*$ & \multicolumn{3}{|c|}{$\begin{array}{l}\text { Lucas Nogueira Paulo Sampaio Wilken } \\
\text { Garcez }\end{array}$} \\
\hline Construção II & $\begin{array}{l}\text { Fernando José de } \\
\text { Oliveira Escorel }\end{array}$ & $*$ & \multicolumn{3}{|c|}{ Fernando José de Oliveira Escorel } \\
\hline $\begin{array}{l}\text { Estruturas Correntes de Madeira Metálicas e } \\
\text { de Concreto Simples e Armado }\end{array}$ & $\begin{array}{l}\text { José Carlos de } \\
\text { Figueiredo Ferraz }\end{array}$ & $*$ & \multicolumn{3}{|c|}{ José Carlos de Figueiredo Ferraz } \\
\hline Grandes Estruturas & $\begin{array}{l}\text { Pedro Bento } \\
\text { José Gravina }\end{array}$ & $*$ & \multicolumn{3}{|c|}{ Pedro Bento José Gravina } \\
\hline $\begin{array}{l}\text { Disciplina Autônoma I2I - } \\
\text { Comunicação Visual I }\end{array}$ & $\begin{array}{l}\text { Ernest Robert de } \\
\text { Carvalho Mange }\end{array}$ & $*$ & \multicolumn{3}{|c|}{ Ernest Robert de Carvalho Mange } \\
\hline $\begin{array}{l}\text { Disciplina Autônoma I22 - } \\
\text { Comunicação Visual II }\end{array}$ & $*$ & $*$ & $*$ & $\begin{array}{l}\text { Renina Katz } \\
\text { Pedreira }\end{array}$ & $\begin{array}{l}\text { Renina Katz } \\
\text { Pedreira/ } \\
\text { Flávio Império }\end{array}$ \\
\hline $\begin{array}{l}\text { Disciplina Autônoma I23 - } \\
\text { Comunicação Visual III }\end{array}$ & $*$ & $*$ & $*$ & \begin{tabular}{|l} 
João \\
Baptista \\
Alves Xavier
\end{tabular} & $\begin{array}{l}\text { João B. A. Xavier } \\
\text { e Ludovico } \\
\text { Antonio Martino }\end{array}$ \\
\hline $\begin{array}{l}\text { Disciplina Autônoma I3I - } \\
\text { Desenho Industrial I }\end{array}$ & $*$ & $*$ & $*$ & $*$ & $*$ \\
\hline $\begin{array}{l}\text { Disciplina Autônoma I32 - } \\
\text { Desenho Industrial II }\end{array}$ & $*$ & $*$ & $*$ & \multicolumn{2}{|c|}{ Lúcio Grinover } \\
\hline $\begin{array}{l}\text { Disciplina Autônoma I33 - } \\
\text { Desenho Industrial III }\end{array}$ & $\begin{array}{l}\text { José Maria da } \\
\text { Silva Neves }\end{array}$ & $*$ & \multicolumn{3}{|c|}{ José Maria da Silva Neves } \\
\hline $\begin{array}{l}\text { Disciplina Autônoma I34 - } \\
\text { Desenho Industrial IV }\end{array}$ & * & $*$ & $*$ & \multicolumn{2}{|c|}{$\begin{array}{l}\text { Luiz Roberto de } \\
\text { Carvalho Franco }\end{array}$} \\
\hline Projeto I ( $\mathrm{I}^{\mathrm{a}}$ e $2^{\mathrm{a}}$ partes $)$ & Hélio de Q. Duarte & $*$ & \multicolumn{3}{|c|}{ Hélio de Queiroz Duarte } \\
\hline Projeto II $\left(3^{\circ}\right.$ ano $)$ & Abelardo R. de Souza & $*$ & \multicolumn{3}{|c|}{ Abelardo Riedy de Souza } \\
\hline $\begin{array}{l}2^{\circ} \text { ano - Projeto e Planejamento } \\
\text { (planejamento apenas assessora da cadeira } \\
\text { de projeto) }\end{array}$ & 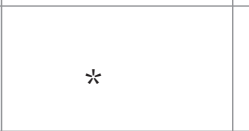 & $*$ & $*$ & $*$ & $*$ \\
\hline Projeto III & Roberto C. César & $*$ & \multicolumn{3}{|c|}{ Roberto Cerqueira César } \\
\hline Projeto IV & $\begin{array}{l}\text { João B. Vilanova } \\
\text { Artigas }\end{array}$ & $*$ & \multicolumn{3}{|c|}{ João Batista Vilanova Artigas } \\
\hline Planejamento I & Roberto C. Cardozo & * & \multicolumn{3}{|c|}{ Roberto Coelho Cardozo } \\
\hline Planejamento II & Lauro Bastos Birkholz & $*$ & \multicolumn{3}{|c|}{ Lauro Bastos Birkholz } \\
\hline História da Arte. Estetica. & \begin{tabular}{l|l} 
Flávio Motta & \\
\end{tabular} & $*$ & \multicolumn{3}{|c|}{ Flávio Motta } \\
\hline História da Arquitetura I & Joaquim B. da Silva & $*$ & \multicolumn{3}{|c|}{ Joaquim Bezerra da Silva } \\
\hline História da Arquitetura II & $\begin{array}{l}\text { Nestor Goulart } \\
\text { Reis Filho }\end{array}$ & $*$ & \multicolumn{3}{|c|}{ Nestor Goulart Reis Filho } \\
\hline História da Arquitetura III & Eduardo Augusto & $*$ & \multicolumn{3}{|c|}{ Eduardo Augusto Kneese de Mello } \\
\hline Historia da Arquitetura IV (a partir de I965) & $\begin{array}{c}\text { Kneese de Mello } \\
*\end{array}$ & $*$ & \multicolumn{3}{|c|}{ Eduardo Corona } \\
\hline Estudos Sociais e Econômicos & Juarez Brandão & $*$ & \multicolumn{3}{|c|}{ Juarez Brandão Rubens Lopes } \\
\hline $\begin{array}{l}\text { Mecânica dos Solos e Fundações } \\
\text { (a partir de } 1967 \text { ) }\end{array}$ & Rubens Lopes & $*$ & (1) & 年 & $\begin{array}{l}\text { Victor Froilano } \\
\text { Bachmann de } \\
\text { Mello }\end{array}$ \\
\hline
\end{tabular}

* Estrutura Curricular nos programas das disciplinas. s/n - programa sem identificação do docente;

* - Programa não acessado 
Cadeira 1968

\begin{tabular}{|c|c|}
\hline $\begin{array}{l}\text { Cálculo Diferencial e Integral. Geometria } \\
\text { Analítica. Nomografia }\end{array}$ & $*$ \\
\hline Geometria Descritiva e Aplicações & $*$ \\
\hline Mecânica & $*$ \\
\hline $\begin{array}{l}\text { Topografia. Elementos de } \\
\text { Astronomia de Posição }\end{array}$ & $*$ \\
\hline Física Geral e Aplicada & $*$ \\
\hline Construção I & * \\
\hline $\begin{array}{l}\text { Resistência dos Materiais e } \\
\text { Estabilidade das Construções. }\end{array}$ & $*$ \\
\hline Hidráulica e Saneamento & $*$ \\
\hline Construção II & $*$ \\
\hline $\begin{array}{l}\text { Estruturas Correntes de Madeira Metálicas e } \\
\text { de Concreto Simples e Armado }\end{array}$ & $*$ \\
\hline Grandes Estruturas & $*$ \\
\hline $\begin{array}{l}\text { Disciplina Autônoma I2I - } \\
\text { Comunicação Visual I }\end{array}$ & $\begin{array}{l}\text { João Baptista Alves Xavier/ Luiz Gastão de Castro } \\
\text { Lima/ Elide Monteziglio (licença prêmio) }\end{array}$ \\
\hline $\begin{array}{l}\text { Disciplina Autônoma I22 - } \\
\text { Comunicação Visual II }\end{array}$ & $\begin{array}{l}\text { Renina Katz Pedreira/ Flávio Império/ Juarez } \\
\text { Brandão Rubens Lopes (colaborador) }\end{array}$ \\
\hline $\begin{array}{l}\text { Disciplina Autônoma I23 - } \\
\text { Comunicação Visual III }\end{array}$ & Ludovico Antônio Martino \\
\hline $\begin{array}{l}\text { Disciplina Autônoma I3I - } \\
\text { Desenho Industrial I }\end{array}$ & João Carlos Cauduro/ Eduardo de Almeida \\
\hline $\begin{array}{l}\text { Disciplina Autônoma I32 - } \\
\text { Desenho Industrial II }\end{array}$ & $\begin{array}{l}\text { Marlene Piccarelli/ Ronaldo Duschenes } \\
\text { (a ser contratado) }\end{array}$ \\
\hline $\begin{array}{l}\text { Disciplina Autônoma I33 - } \\
\text { Desenho Industrial III }\end{array}$ & $\begin{array}{l}\text { João Carlos Rodolpho Stroeter/ } \\
\text { Abrahão Velvu Sanovicz }\end{array}$ \\
\hline $\begin{array}{l}\text { Disciplina Autônoma I34 - } \\
\text { Desenho Industrial IV }\end{array}$ & Lúcio Grinover \\
\hline Projeto I ( $\mathrm{I}^{\mathrm{a}}$ e $2^{\mathrm{a}}$ partes) & $\begin{array}{l}\text { Hélio de Queiroz Duarte/ Siegbert Zanettini/ Pedro Paulo de } \\
\text { Melo Saraiva/ Dario Montesano (instrutor a ser contratado) }\end{array}$ \\
\hline Projeto II $\left(3^{\circ}\right.$ ano $)$ & Roger Zmekhol/ Gian Carlo Gasperini \\
\hline $\begin{array}{l}2^{\circ} \text { ano - Projeto e Planejamento } \\
\text { (planejamento apenas assessora da cadeira } \\
\text { de projeto) }\end{array}$ & $\begin{array}{l}\text { Paulo Archias Mendes da Rocha/ Jon Andoni Vergareche } \\
\text { Maitrejean/ Miranda Maria Martinello Magnioli/ Antônio Augusto } \\
\text { Antunes Netto/ Milton Carlos Ghiraldini (licença-prêmio) }\end{array}$ \\
\hline Projeto III & $\begin{array}{l}\text { Abelardo Riedy de Souza/ Cândido Malta Campos } \\
\text { Filho/ Roberto José Goulart Tibau }\end{array}$ \\
\hline Projeto IV & João Batista Vilanova Artigas \\
\hline Planejamento I & Brenno Cyrino Nogueira/ Marcos de Souza Dias (a ser contratado) \\
\hline Planejamento II & José Claudio Gomes \\
\hline História da Arte. Estetica. & $*$ \\
\hline História da Arquitetura I & $*$ \\
\hline História da Arquitetura II & $*$ \\
\hline História da Arquitetura III & $*$ \\
\hline Historia da Arquitetura IV (a partir de I965) & $*$ \\
\hline Estudos Sociais e Econômicos & $*$ \\
\hline $\begin{array}{l}\text { Mecânica dos Solos e Fundações } \\
\text { (a partir de } 1967 \text { ) }\end{array}$ & $*$ \\
\hline
\end{tabular}

* Estrutura Curricular nos programas das disciplinas. s/n - programa sem identificação do docente;

* - Programa não acessado 


\section{APÊNDICE B - CORPO DOCENTE DAS CADEIRAS DE COMPOSIÇÃO DE ARQUITETURA (1948-1962)}

\begin{tabular}{|c|c|c|c|c|c|}
\hline Cátedra & 1948 & 1949 & 1950 & 1951 & 1952 \\
\hline \multirow{2}{*}{$\begin{array}{l}\text { Composição Arquitetônica - } \\
\text { Pequenas composições ( }{ }^{\circ} \text { ano) }\end{array}$} & \multirow{2}{*}{$\begin{array}{l}\text { Vilanova } \\
\text { Artigas } \\
\text { Abelardo } \\
\text { de Souza } \\
\text { (assistente) }\end{array}$} & \multicolumn{4}{|c|}{ Zenon Lotufo ( $\mathrm{r}^{\circ}$ ano) } \\
\hline & & $\begin{array}{l}\text { Hélio de } \\
\text { Queiroz Duarte } \\
\text { (assistente) }\end{array}$ & $\begin{array}{l}\text { Ícaro de } \\
\text { (assiste }\end{array}$ & tro Mell & \\
\hline \multirow{2}{*}{$\begin{array}{l}\text { Composição Arquitetônica - } \\
\text { Pequenas composições }\left(2^{\circ} \text { ano }\right)\end{array}$} & \multirow{2}{*}{$\begin{array}{l}\text { não } \\
\text { ministrada }\end{array}$} & $\begin{array}{l}\text { Vilanova } \\
\text { Artigas }\end{array}$ & \multicolumn{3}{|c|}{ Vilanova Artigas? } \\
\hline & & \multicolumn{4}{|c|}{ Abelardo de Souza (assistente) } \\
\hline \multirow{2}{*}{$\begin{array}{l}\text { Composição Arquitetônica - } \\
\text { Grandes composições ( } 3^{\circ} \text { Ano) }\end{array}$} & \multirow{2}{*}{\multicolumn{2}{|c|}{ não ministrada }} & \multicolumn{3}{|c|}{ Hélio de Queiroz Duarte } \\
\hline & & & \multicolumn{3}{|c|}{$\begin{array}{l}\text { Ernest Robert Carvalho Mange } \\
\text { (assistente) }\end{array}$} \\
\hline $\begin{array}{l}\text { Composição Arquitetônica - } \\
\text { Grandes composições ( } 4^{\circ} \text { Ano) }\end{array}$ & \multicolumn{2}{|c|}{ não ministrada } & \multicolumn{3}{|c|}{ José Vicente Vicari } \\
\hline \multirow[t]{2}{*}{$\begin{array}{l}\text { Composição Arquitetônica - } \\
\text { Grandes composições (5 Ano) }\end{array}$} & \multirow{2}{*}{\multicolumn{2}{|c|}{ não ministrada }} & & & $\begin{array}{l}\text { Elisário } \\
\text { da Cunha } \\
\text { Bahiana }\end{array}$ \\
\hline & & & & & $\begin{array}{l}\text { não } \\
\text { identificado }\end{array}$ \\
\hline
\end{tabular}




\begin{tabular}{|c|c|c|c|c|c|}
\hline Cátedra & 1953 & 1954 & 1955 & 1956 & 1957 \\
\hline \multirow{2}{*}{$\begin{array}{l}\text { Composição Arquitetônica - } \\
\text { Pequenas composições ( }{ }^{\circ} \text { ano) }\end{array}$} & \multicolumn{2}{|c|}{ Zenon Lotufo } & $\begin{array}{l}\text { Ícaro de } \\
\text { Castro Mello? }\end{array}$ & \multirow{2}{*}{\multicolumn{2}{|c|}{$\begin{array}{l}\text { Zenon Lotufo } \\
\text { Vilanova Artigas } \\
\text { (assistente) }\end{array}$}} \\
\hline & $\begin{array}{l}\text { Ícaro de } \\
\text { Castro Mello } \\
\text { (assistente) }\end{array}$ & \multicolumn{2}{|c|}{ Oswaldo Gonçalves Corrêa ? } & & \\
\hline \multirow{2}{*}{$\begin{array}{l}\text { Composição Arquitetônica - } \\
\text { Pequenas composições ( } 2^{\circ} \text { ano) }\end{array}$} & $\begin{array}{l}\text { Vilanova } \\
\text { Artigas* }\end{array}$ & $\begin{array}{l}\text { não } \\
\text { identificado }\end{array}$ & \multicolumn{3}{|c|}{ Hélio de Queiroz Duarte } \\
\hline & $\begin{array}{l}\text { Abelardo } \\
\text { de Souza } \\
\text { (assistente) }\end{array}$ & $\begin{array}{l}\text { não } \\
\text { identificado }\end{array}$ & \multicolumn{3}{|c|}{ Plínio Croce (assistente) } \\
\hline \multirow{2}{*}{$\begin{array}{l}\text { Composição Arquitetônica - } \\
\text { Grandes composições ( } 3^{\circ} \text { Ano) }\end{array}$} & $\begin{array}{l}\text { Hélio de } \\
\text { Queiroz } \\
\text { Duarte }\end{array}$ & $\begin{array}{l}\text { Plínio } \\
\text { Croce }\end{array}$ & \multicolumn{3}{|c|}{ Abelardo Riedy de Souza } \\
\hline & $\begin{array}{l}\text { Ernest R. C. } \\
\text { Mange } \\
\text { (assistente) }\end{array}$ & \begin{tabular}{|l|} 
Ícaro de \\
Castro Mello \\
(assistente)
\end{tabular} & \multicolumn{3}{|c|}{ Jon A. V. Maitrejean (assistente) } \\
\hline \multirow{2}{*}{$\begin{array}{l}\text { Composição Arquitetônica - } \\
\text { Grandes composições ( } 4^{\circ} \text { Ano) }\end{array}$} & $\begin{array}{l}\text { José Vicente } \\
\text { Vicari }\end{array}$ & 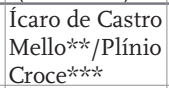 & $\begin{array}{l}\text { Zenon Lotufo/ } \\
\text { Helio Duarte }\end{array}$ & \multicolumn{2}{|c|}{ José Vicente Vicari } \\
\hline & $\begin{array}{l}\text { Hélio de } \\
\text { Queiroz } \\
\text { Duarte }\end{array}$ & $\begin{array}{l}\text { Oswaldo } \\
\text { Gonçalves } \\
\text { Corrêa } * *\end{array}$ & $\begin{array}{l}\text { Manoel da } \\
\text { Silva Machado } \\
\text { (assistente)/ } \\
\text { Ernest R. de } \\
\text { C. Mange }\end{array}$ & & $\begin{array}{l}\text { Hélio de } \\
\text { Queiroz } \\
\text { Duarte }\end{array}$ \\
\hline \multirow{2}{*}{$\begin{array}{l}\text { Composição Arquitetônica - } \\
\text { Grandes composições (5Ano) }\end{array}$} & $\begin{array}{l}\text { Elisário da } \\
\text { Cunha Bahiana }\end{array}$ & \multicolumn{4}{|c|}{ Rino Levi } \\
\hline & $\begin{array}{l}\text { não } \\
\text { identificado }\end{array}$ & \begin{tabular}{|l} 
não \\
identificado
\end{tabular} & \multicolumn{3}{|c|}{ Roberto C. César (assistente) } \\
\hline Cátedra & 1958 & 1959 & 1960 & 1961 & 1962 \\
\hline \multirow{2}{*}{$\begin{array}{l}\text { Composição Arquitetônica - } \\
\text { Pequenas composições ( }{ }^{\circ} \text { ano) }\end{array}$} & \multicolumn{5}{|c|}{ Hélio de Queiroz Duarte } \\
\hline & \multicolumn{5}{|c|}{ não identificado } \\
\hline \multirow{2}{*}{$\begin{array}{l}\text { Composição Arquitetônica - } \\
\text { Pequenas composições ( } 2^{\circ} \text { ano) }\end{array}$} & \multicolumn{5}{|c|}{ Hélio de Queiroz Duarte } \\
\hline & \multicolumn{5}{|c|}{ Plínio Croce (assistente) } \\
\hline \multirow{2}{*}{$\begin{array}{l}\text { Composição Arquitetônica - } \\
\text { Grandes composições ( } 3^{\circ} \text { Ano) }\end{array}$} & \multicolumn{5}{|c|}{ Abelardo Riedy de Souza } \\
\hline & \multicolumn{5}{|c|}{ Jon A. V. Maitrejean (assistente) } \\
\hline \multirow{2}{*}{$\begin{array}{l}\text { Composição Arquitetônica - } \\
\text { Grandes composições ( } 4^{\circ} \text { Ano) }\end{array}$} & \multicolumn{5}{|c|}{ Roberto Cerqueira César } \\
\hline & $\begin{array}{l}\text { Luiz } \\
\text { Roberto } \\
\text { Carvalho } \\
\text { Franco } \\
\text { (Assistente) } \\
\end{array}$ & \multicolumn{4}{|c|}{$\begin{array}{l}\text { Carlos Millán/ Luiz Roberto de } \\
\text { Carvalho FrancoGonçalves Corrêa *** }\end{array}$} \\
\hline \multirow{2}{*}{$\begin{array}{l}\text { Composição Arquitetônica - } \\
\text { Grandes composições (5ªno) }\end{array}$} & Rino Levi & $\begin{array}{l}\text { Vilanova } \\
\text { Artigas }\end{array}$ & \multicolumn{3}{|c|}{ Vilanova Artigas } \\
\hline & $\begin{array}{l}\text { Vilanova } \\
\text { Artigas } \\
\text { (assistente) }\end{array}$ & $\begin{array}{l}\text { não } \\
\text { identificado }\end{array}$ & \multicolumn{3}{|c|}{ Paulo A. Mendes da Rocha (Assistente) } \\
\hline
\end{tabular}

*Depoimento de alunos que estudaram entre 52 e 56 contradiz afirmação de Sanovicz e Lima de Toledo de que ele saiu após a greve

$* *$ Segundo Ficher (2005)

**** Segundo depoimento do ex-aluno Araken Martino (in SODRÉ, 2009) 


\section{APÊNDICE C - RENOVAÇÃO DO CORPO DOCENTE DA FAUUSP}

A seguir, apresentamos a relação dos profissionais contratados pela FAUUSP entre 1948 e 1962 que, de alguma maneira, rompiam com a tradição politécnica, seja pelo desenvolvimento de uma linguagem ligada à arquitetura moderna, pelo envolvimento com as instituições de arquitetura que se fortaleciam em defesa da arquitetura moderna, como o IAB, ou então pela importante contribuição que trariam por ocasião da reforma de ensino de 1962. Todavia, o quadro abaixo tem um caráter orientador da análise e não pretende esgotar todas as contribuições para a formação de um posicionamento moderno na FAUUSP. Também não foi nossa intenção apresentar esses docentes como parte de um corpo homogêneo. A relação dos profissionais apresentados segue a ordem cronológica de sua contratação.

\section{Renovação do corpo docente da FAUUSP}

\begin{tabular}{|c|c|c|c|}
\hline Nome & Origem & $\begin{array}{l}\text { Cadeira da FAUUSP } \\
\text { inicialmente ocupada }\end{array}$ & $\begin{array}{l}\text { Período em } \\
\text { que lecionou }\end{array}$ \\
\hline $\begin{array}{l}\text { João Batista Vilanova } \\
\text { Artigas }\end{array}$ & $\begin{array}{l}\text { Escola Politécnica - } \\
\text { Eng. Arq. (I937) }\end{array}$ & $\begin{array}{l}\text { Pequenas Composições I } \\
\left(\mathrm{I}^{\circ} \text { ano }\right)\end{array}$ & $\begin{array}{l}\text { I948-I969/ } \\
\text { I980-1984 }\end{array}$ \\
\hline $\begin{array}{l}\text { Abelardo Riedy } \\
\text { de Souza }\end{array}$ & ENBA (I932) & $\begin{array}{l}\text { Pequenas Composições I } \\
\left(\mathrm{I}^{\circ} \text { ano) }\right.\end{array}$ & I948-I978 \\
\hline $\begin{array}{l}\text { Hélio de Queiroz } \\
\text { Duarte }\end{array}$ & ENBA (I930) & $\begin{array}{l}\text { Pequenas Composições I } \\
\left(\mathrm{I}^{\circ} \text { ano }\right)\end{array}$ & I949-1976 \\
\hline Eduardo Corona & FNA (I946) & Teoria da Arquitetura & I949-I99I \\
\hline Zenon Lotufo & $\begin{array}{l}\text { Escola Politécnica - } \\
\text { Eng. Arq. (1936) }\end{array}$ & $\begin{array}{l}\text { Pequenas Composições I } \\
\left(\mathrm{I}^{\circ} \text { ano }\right)\end{array}$ & I949-1957 \\
\hline $\begin{array}{l}\text { Alcides da Rocha } \\
\text { Miranda }\end{array}$ & ENBA (I932) & Plástica & I950-I955 \\
\hline Ícaro de Castro Mello & $\begin{array}{l}\text { Escola Politécnica - } \\
\text { Eng. Arq. (1935) }\end{array}$ & $\begin{array}{l}\text { Pequenas Composições I } \\
\left(\mathrm{I}^{\circ} \text { ano }\right)\end{array}$ & I950-1956 \\
\hline $\begin{array}{l}\text { Ernest Robert de } \\
\text { Carvalho Mange }\end{array}$ & $\begin{array}{l}\text { Escola Politécnica - } \\
\text { Eng. Civil (I945) }\end{array}$ & $\begin{array}{l}\text { Grandes Composições I } \\
\text { Pequenas Composições I } \\
\left(3^{\circ} \text { ano }\right)\end{array}$ & $1950-1969$ \\
\hline $\begin{array}{l}\text { Milton Carlos } \\
\text { Ghiraldini }\end{array}$ & $\begin{array}{l}\text { Mackenzie - Eng. Civil e } \\
\text { Mackenzie - Arq. (data não } \\
\text { identificada) }\end{array}$ & Urbanismo & I952-1976 \\
\hline Miguel Badra Júnior & $\begin{array}{l}\text { Escola Politécnica - } \\
\text { Eng. Arq. (I945) }\end{array}$ & Teoria da Arquitetura & I952-I954 \\
\hline Plínio Croce & $\begin{array}{l}\text { Mackenzie - } \\
\text { Eng. Arq. (I946) }\end{array}$ & $\begin{array}{l}\text { Composições (ano não } \\
\text { identificado) }\end{array}$ & I952-1967 \\
\hline $\begin{array}{l}\text { Jon Andoni Vergareche } \\
\text { Maitrejean }\end{array}$ & FAUUSP (1953) & $\begin{array}{l}\text { Grandes Composições I } \\
\left(3^{\circ} \text { ano }\right)\end{array}$ & $\begin{array}{l}\text { I954-I969/ } \\
\text { I980-1987 }\end{array}$ \\
\hline
\end{tabular}




\begin{tabular}{|c|c|c|c|}
\hline Nome & Origem & $\begin{array}{l}\text { Cadeira da FAUUSP } \\
\text { inicialmente ocupada }\end{array}$ & $\begin{array}{l}\text { Período em } \\
\text { que lecionou }\end{array}$ \\
\hline $\begin{array}{l}\text { Oswaldo Corrêa } \\
\text { Gonçalves }\end{array}$ & $\begin{array}{l}\text { Escola Politécnica - } \\
\text { Eng. Arq. (I94I) }\end{array}$ & $\begin{array}{l}\text { Pequenas Composições I } \\
\text { (涪 ano?) }\end{array}$ & I954-I956 \\
\hline Rino Levi & $\begin{array}{l}\text { Escola Superior de } \\
\text { Arquitetura de Roma (1926) }\end{array}$ & $\begin{array}{l}\text { Grandes Composições III } \\
\left(5^{\circ} \text { ano }\right)\end{array}$ & I954-I959 \\
\hline Roberto Cerqueira César & $\begin{array}{l}\text { Escola Politécnica - } \\
\text { Eng. Arq. (I940) }\end{array}$ & $\begin{array}{l}\text { Grandes Composições III } \\
\left(4^{\circ} \text { ano }\right)\end{array}$ & I954-I966 \\
\hline Flávio L. Motta & FFLC - Pedagogia (I946) & História da Arte. Estética. & I954-I983 \\
\hline $\begin{array}{l}\text { Mario Wagner } \\
\text { Vieira da Cunha }\end{array}$ & $\begin{array}{l}\text { Faculdade de Direito USP } \\
\text { (1936) }\end{array}$ & $\begin{array}{l}\text { Economia politica, Esta- } \\
\text { tística aplicada. Organi- } \\
\text { zações administrativas }\end{array}$ & I954-I959 \\
\hline Achilina Bo Bardi & $\begin{array}{l}\text { Escola Superior de Arqui- } \\
\text { tetura de Roma (déc. I939) }\end{array}$ & $\begin{array}{l}\text { Composições (ano não } \\
\text { identificado) }\end{array}$ & I955-I956 \\
\hline José de Souza Reis & ENBA (I932) & Arquitetura no Brasil & I955 (I mês) \\
\hline $\begin{array}{l}\text { Eduardo Kneese } \\
\text { de Mello }\end{array}$ & $\begin{array}{l}\text { Mackenzie - } \\
\text { Eng. Arq. (I934) }\end{array}$ & Arquitetura no Brasil & I955-I976 \\
\hline $\begin{array}{l}\text { Luiz Gastão de Castro } \\
\text { Lima }\end{array}$ & FAUUSP (I954) & Composição Decorativa & 1956-1972 \\
\hline Renina Katz Pedreira & ENBA (I950) & Não identificado & I956-1983 \\
\hline $\begin{array}{l}\text { Roberto José } \\
\text { Goulart Tibau }\end{array}$ & FNA (1949) & Urbanismo & I957-I986 \\
\hline Élide Monzeglio & Belas Artes - SP (1953) & Não identificado & I958-I986 \\
\hline $\begin{array}{l}\text { Luiz Roberto } \\
\text { Carvalho Franco }\end{array}$ & FAUM (I95I) & Grandes Composições II & I958-1966 \\
\hline Lúcio Grinover & FAUUSP (I957) & Composição Decorativa & I958-I988 \\
\hline Carlos Barjas Millán & FAUM (I95I) & Grandes Composições II & $1959-1964$ \\
\hline Gian Carlo Gasperini & FNA (1949) & Não identificado & I960-1966 \\
\hline $\begin{array}{l}\text { Miranda M. E.M. } \\
\text { Maglioli }\end{array}$ & FAUUSP (I955) & Não identificado & I960-1988 \\
\hline $\begin{array}{l}\text { Paulo A. } \\
\text { Mendes da Rocha }\end{array}$ & FAUM (I954) & Grandes Composições II & 1960-1999 \\
\hline Abrahão Velvu Sanovicz & FAUUSP (I958) & Composição Decorativa & I962-1999 \\
\hline Júlio Roberto Katinsky & FAUUSP (I957) & História da Arte. Estética & $1962-2002$ \\
\hline $\begin{array}{l}\text { João Baptista } \\
\text { Alves Xavier }\end{array}$ & FAUUSP (I958) & Não identificado & $1962-1964$ \\
\hline Flávio Império & FAUUSP (I96I) & Não identificado & I962-I977 \\
\hline Rodrigo Brotero Lefèvre & FAUUSP (I96I) & Não identificado & I962-I984 \\
\hline Sérgio Ferro Pereira & FAUUSP (I96I) & História da Arte. Estética & I963-1973 \\
\hline $\begin{array}{l}\text { Pedro Paulo de Mello } \\
\text { Saraiva }\end{array}$ & FAUM (I955) & Não identificado & 1962-1970 \\
\hline
\end{tabular}




\section{APÊNDICE D - OS PROFESSORES DE COMPOSIÇÃO}

Neste Apêndice, reconstituímos parte da trajetória dos professores de das cadeiras de composição de arquitetura na FAUUSP, conforme as informações que pudemos levantar. Todavia, lacunas na documentação consultada não nos permitem identificar com precisão todos os profissionais envolvidos no ensino dessas cadeiras. É interessante observar o contexto de formação desses profissionais, assim como seus posicionamentos acerca dos assuntos de arquitetura e urbanismo e relacioná-los com o contexto social no âmbito do qual seus pensamentos foram formulados.

\section{João Batista Vilanova Artigas}

Artigas parece ter sido um dos professores mais admirados pelos antigos estudantes da FAUUSP, embora sua carreira na universidade tenha sido bastante conturbada. Em 1948, quando apenas a cadeira de composição de arquitetura do primeiro ano do curso esteve em funcionamento, foi ele o seu professor responsável, tendo por assistente Abelardo Riedy de Souza, recém-contratado. Entre 1948 e 1969, ano de sua aposentadoria compulsória, o arquiteto foi afastado da faculdade em diversas ocasiões, sobretudo em decorrência de conflitos de ordem política. Não pudemos precisar com exatidão quais foram esses momentos. Entretanto, sabe-se que por ocasião da greve de 1951, Artigas foi realocado na Escola Politécnica por algum tempo, conforme depoimento de Abrahão Sanovicz (formado pela FAUUSP em 1958):

(...) Depois da greve do Niemeyer houve o afastamento de alguns professores, que foram mandados de volta para a Politécnica. O Artigas foi um deles. Não foi a primeira vez que o puseram de castigo. Quando voltou à FAU, em 1956 ou 57, vivia um momento muito interessante: participara do concurso de Brasilia que premiou Lúcio Costa, depois participou do grupo de arquitetos que reformulou a Cidade Universitária e projetou o prédio da FAU. E foi justamente nessa época que ocorreu a reforma de ensino. Ele conseguiu entender o processo de modernização que o país estava precisando em matéria de ensino (SANOVICZ, 1997, p. 48, apud AYOUB, 2006, p. 274).

Benedito Lima de Toledo, que estudou na FAUUSP entre 1956 e 1961, também comentou o afastamento de Artigas durante os anos 1950, afirmando que seu retorno se deu na sua própria turma de alunos, portanto, em $1956^{1}$ (apud SODRÉ, 2009, p. 158). Se o início do afastamento de Artigas se deu realmente em 1951, então após apenas quatro anos

1 Entretanto, estudantes como Araken Martinho e Ubyrajara Gonsalves Glioli, que estudaram na FAUUSP entre 1952 e 1956 alegam terem tido aula com Artigas no segundo ano (apud SODRÉ, 2009). 
de docência na faculdade ele foi afastado por mais seis anos. Entretanto, em 1955 ele foi convidado a ser paraninfo da turma de formandos (ARTIGAS, 2004, p. 63) ${ }^{2}$. Quando retornou à FAUUSP, foi primeiramente realocado como assistente de Pequenas Composições I com Zenon Lotufo, a convite desse docente. Todavia, em agosto de 1957, Lotufo escreveu um ofício ao diretor alegando que "não merecendo mais minha confiança solicito o seu afastamento imediato” (apud ALBUQUERQUE, 2004, p. 140). Após esse episódio, Rino Levi, que regia a cadeira de Grandes Composições II, convidou-o a tornar-se seu assistente. Quando Rino Levi afastou-se definitivamente da escola, no início de 1960, Artigas passou a ser o docente responsável pela cadeira, nela permanecendo até a reforma de 1962, quando ficou a cargo da disciplina de Projeto IV.

Em 1964, Artigas também foi afastado, tendo se exilado por um breve período no Uruguai (ARTIGAS, 2004, p. 85). Em sua pasta funcional, consta um ofício do General Leocádio do Rego Chaves, General de Divisão R-1 encarregado do Inquérito Policial Militar, informando que o docente havia sido preso às $17 \mathrm{~h} 00$ de 04/09/1964, tendo sido liberado às 9 h30 de 16/09/1964. Finalmente, em 30/04/1969, Artigas foi aposentado por ato do presidente General Arthur da Costa e Silva, conforme o Decreto n²9 do Diário Oficial da União. Ironicamente, nesse mesmo ano o arquiteto foi premiado na X Bienal de Arquitetura em decorrência de seu projeto para o edifício da FAUUSP na Cidade Universitária (Ofício n ${ }^{\circ}$ GD/639 de 07/10/1969). Mais ainda, foi a partir de então que Artigas desenvolveu a maior parte de seus projetos para edifícios públicos no Brasil ${ }^{3}$. O professor somente retornou à FAUUSP onze anos depois, em 1980, readmitido conforme a Lei da Anistia (Lei Federal $n^{\circ}$ $6.683 / 1979)$.

Seus antigos alunos o retrataram como um professor de grande conhecimento, acessível, eloquente, motivador, por vezes excessivamente impositivo, mas muito admirado. Nas palavras de Wilson Rodrigues de Moraes, que estudou na primeira turma da FAUUSP, "ele conhecia tudo, as tendências, os principais artistas, os principais arquitetos, impressionante o cara. Tanto que a turma respeitava o Artigas por isso, não porque ele era um professor catedrático. Era pelo saber do Artigas" (apud SODRÉ, 2009, p. 40).

Em 1957, Artigas orientou a equipe de estudantes que venceu o III Concurso Internacional de Escolas de Arquitetura, vinculado à IV Bienal de Arquitetura de São Paulo (Ofício n D-123/57, de 6/02/1957, apud ALBUQUERQUE, 2004, p. 165). Os alunos da equipe eram: Abrahão V. Sanovicz, $4^{\circ}$ ano, H. Lira F.S., $4^{\circ}$ ano, Hélio M. Penteado, $4^{\circ}$ ano,

2 A turma de formandos de 1955 havia ingressado na FAUUSP em 1951. É plausível, portanto, que tenha se tratado de uma homenagem em memória à greve.

3 Dentre esses projetos, destacamos: o conjunto de obras realizadas no município de Jaú, no âmbito do Plano de Desenvolvimento Acelerado (1973-1976), durante a administração de Waldemar Bauab e os conjuntos habitacionais e equipamentos públicos para a CECAP - Guarulhos, 1967, Cubatão, 1970, Americana, 1972, Jundiaí, 1973, Mogi-Guaçu, 1975, Marília, 1976 e Jaú, 1976. Artigas também projetou diversas obras públicas em Macapá entre 1970 e 1972, passarelas para municípios da Região Metropolitana de São Paulo na década de 1970 e fez o projeto de reurbanização do Vale do Anhangabaú, no centro de São Paulo, em 1974, dentre diversos outros projetos de obras públicas do arquiteto. A relação do conjunto das obras de Artigas, em ordem cronológica, pode ser consultada na edição especial da revista Módulo sobre o arquiteto, de 1985. 
Israel Sancovscki, $5^{\circ}$ ano, Jaguahara T. Ramos, $5^{\circ}$ ano, Jerônimo E. Bonilha, $5^{\circ}$ ano, João C. Rodolpho Stroeter, $5^{\circ}$ ano, José Caetano de Mello Franco, $4^{\circ}$ ano, Júlio Roberto Katinsky, $5^{\circ}$ ano, e Lúcio Grinover, $5^{\circ}$ ano (Ofício n D-597/57 de 22/10/1957, apud ALBUQUERQUE, 2004, p.167-168) ${ }^{4}$. Vários desses estudantes, como Sanovicz, Katinsky e Grinover viriam a lecionar na FAUUSP pouco tempo depois. Em 1961, Artigas orientou novamente uma equipe de alunos em um projeto que disputou na VI Bienal de Arquitetura de São Paulo, como docente responsável pela Cadeira de Grandes Composições II.

\section{Abelardo Riedy de Souza (1908-198I)}

Abelardo de Souza ingressou na Escola Nacional de Belas Artes em 1927, diplomando-se em 1932. Nesse período, assistiu à reforma de ensino proposta por Lúcio Costa e à greve dos estudantes desencadeada pela sua demissão do cargo de diretor da escola. Sob a direção de Gregori Warchavchik e em parceria com Oscar Niemeyer, Alcides Rocha Miranda, Jorge Moreira, Aníbal Melo Pinto, dentre outros, organizou o Salão de Arquitetura Tropical de 1933, que expunha trabalhos de arquitetura moderna brasileira, além do manifesto do CIAM e outros escritos, divulgados pela primeira vez no país (FERRAZ, 1957, p. 06). Depois de formado, ingressou no curso de urbanismo da Universidade do Distrito Federal, criada em 1935 por iniciativa do educador Anísio Teixeira (CONSTANTINO, 2004, p. 42) ${ }^{5}$. Antes de se transferir para São Paulo, em 1939, trabalhou no escritório de Edgard Vianna e Rafael Galvão, no Departamento de Engenharia do Distrito Federal e no Banco Hipotecário Lar Brasileiro.

Em São Paulo, projetou edifícios representativos da arquitetura moderna, dentre os quais o Edifício Nações Unidas (1952-1959), para o Banco Nacional Imobiliário, e os Edifícios Ministro Godói e Franco da Rocha (1954), no âmbito de um conjunto residencial do Banco Hipotecário Lar Brasileiro em Perdizes (CONSTANTINO, 2004, p. 60). Nos anos 1950, também trabalhou para a revista Habitat, de Pietro Maria e Lina Bo Bardi.

Geraldo Ferraz dedicou o primeiro número de seu projeto "Novos Valores da Arquitetura Brasileira”, publicado em Habitat em 1957, ao trabalho de Abelardo de Souza. De acordo com a apresentação do jornalista, o primeiro edifício significativo de Abelardo de Souza datava de 1938, construído no Rio de Janeiro (Edifício Cananéia). Todavia, considerando que o arquiteto transferiu-se definitivamente para São Paulo em 1939, a maior parte de sua produção foi realizada enquanto ele residiu na capital paulista.

Iniciou a docência na FAUUSP em 1948, aposentando-se em 1978. Foi o primeiro professor externo à USP a ser contratado, como assistente de Artigas na cadeira de Pe-

4 No ofício, os estudantes agradeciam, além de Artigas, os professores Mário Wagner Vieira da Cunha, Hélio de Queiroz Duarte e Roberto Coelho Cardozo, "que mais diretamente colaboraram" (apud ALBUQUERQUE, 2004, p.168).

5 Há incompatibilidade entre Ferraz (1957, p. 05) e Constantino (2004, p. 42) no que se refere à data de ingresso de Abelardo de Souza nesse curso. O primeiro afirma que Abelardo deixou o curso em 1935, quando a escola encerrou suas atividades, ao passo que Constantino afirma que o seu ingresso na escola se deu em 1935, ano em que teve início o funcionamento do curso, concluindo-o em 1937. 
quenas Composições para o primeiro ano. Em 1949, acompanhou Artigas, que passou a lecionar Pequenas Composições para o $2^{\circ}$ Ano. Foi responsável pela Cadeira de Grandes Composições para o $3^{\circ}$ ano desde pelo menos 1955 até sua extinção em 1962. Depois disso, ocupou-se de Projeto II. Também foi responsável pela indicação de professores como Eduardo Corona, assistente de Anhaia Mello em Teoria da Arquitetura, em 1949, Jon A. V. Maitrejean, em 1954, Miranda Magnoli, formada pela FAUUSP em 1955 e contratada como docente em 1960 e Renina Katz, contratada em 1956 para integrar o corpo docente da faculdade (CONSTANTINO, 2004, p. 57). Maitrejean foi seu assistente na Cadeira de Grandes Composições para o $3^{\circ}$ ano. Há indícios de que, desde o princípio, Abelardo de Souza tenha colaborado para constituir uma faculdade de arquitetura moderna na USP, conforme seu próprio testemunho:

Aqui em São Paulo, já estávamos na FAU lecionando, o Anhaia pediu: “olha, você vai ao Rio, conversa com Lúcio Costa, para fazer uma nova programação na Faculdade de Arquitetura: nós estamos muito técnicos demais". Eu fui ao rio, o Lúcio me disse: "olha Abelardo, faz como você aprendeu na Escola de Belas Artes: ligação de Belas Artes com arquitetura que, sem isso, não tem sentido" (apud SANTOS, 1985, p. 79).

\section{Zenon Lotufo (I9II-I985)}

Formado pela Escola Politécnica da USP em 1936, Zenon Lotufo foi assistente de Anhaia Mello em 1938 e em 1947, esta última vez para substituir Artigas, que se encontrava em viagem de estudo nos Estado Unidos. Mondenese Filho (2008, p. 28) assinalou que na Escola Politécnica, Anhaia Mello foi uma influência importante para sua formação.

Na FAUUSP, o arquiteto foi contratado para ocupar a Cadeira de Pequenas Composições I em 1949 no lugar de Artigas, que fora transferido para a Cadeira do $2^{\circ}$ Ano. Lecionou nessa cadeira até 1957, quando prestou o concurso da cátedra, apresentando o ensaio "O espaço psicológico na arquitetura". Entretanto, o exame foi anulado, reprovando-se todos os candidatos ${ }^{6}$. Em 1966, Lotufo retornou à Escola Politécnica como docente, mediante apresentação do trabalho "Arte ou Artifício", que versava sobre a relação entre forma e estrutura na história da arquitetura.

Entre 1946 e 1949 aproximou-se da arquitetura carioca, especialmente a partir da parceria de dois arquitetos que viriam a lecionar com ele na FAUUSP, Abelardo Riedy de Souza e Hélio de Queiroz Duarte. Em 1946 os três arquitetos associaram-se em um escritório de arquitetura na Rua Barão de Itapetininga, desenvolvendo projetos (alguns dos quais não construídos): para a Sede do IAB (o projeto construído é de Rino Levi, Roberto Cerqueira César e Jacob Ruchti), o Grêmio Recreativo de Ourinhos, a Associação Brasileira de Imprensa em Salvador, a Estância Hidromineral Hotel-Cassino, a Cruz Vermelha do Brasil, o Edifício Pedra Azul, o Instituto de Puericultura, o Orfanato Amando de Barros, a Cerâmi-

6 Lotufo concorreu com os arquitetos Mário Russo, Paulo Camargo de Almeida e Ernest Robert de Carvalho Mange (MONDENESE FILHO, 2008, p. 111). 
ca São Caetano e o Edifício Hecilda. Trabalhou com Oscar Niemeyer durante a realização dos pavilhões do Parque Ibirapuera entre 1951 e 1955. Também estabeleceu parcerias com Gregori Warchavchik (Clube Atlético Paulistano), Plínio Croce (Faculdade de Engenharia Industrial), dentre outros.

\section{Hélio de Queiroz Duarte (1906-1989)}

Hélio Duarte formou-se na Escola Nacional de Belas Artes, no Rio de Janeiro, em 1930. Trabalhou no escritório de Nestor de Figueiredo em 1933, no desenvolvimento dos planos urbanísticos do Recife, de João Pessoa e Cabedelo. Antes de se instalar em São Paulo, em 1944, foi docente na Escola de Belas Artes da Bahia, em Salvador, cidade em que residiu desde 1936. Lá, lecionou "Arquitetura Analítica", "Composições de Arquitetura" e "Urbanismo" (Pasta Funcional do docente na FAUUSP). Além da docência, em Salvador atuou como arquiteto do Banco Hipotecário Lar Brasileiro e como arquiteto-chefe da Companhia Brasileira Imobiliária e de Construções. Foi em função desse emprego que o arquiteto se transferiu para São Paulo. Algumas de suas principais realizações de arquitetura naquela década se deram através da sociedade com Abelardo de Souza e Zenon Lotufo, quando participaram de diversos concursos.

Em sua produção como arquiteto, os programas de edifícios voltados para a educação ocuparam uma posição central. Nesse aspecto, as ideias do educador Anísio Teixeira o influenciaram fortemente. Entre 1948 e 1955, coordenou a equipe de arquitetos que projetou, ao todo, 68 edifícios alinhados com os preceitos da arquitetura moderna para o Convenio Escolar da Prefeitura Municipal de São Paulo ${ }^{7}$. Além disso, desenvolveu planos e edifícios de diversos campi universitários, dentre os quais o da Escola de Engenharia de São Carlos, da Universidade de Santa Catarina e o do campus tecnológico da Universidade Federal do Ceará. Em dezembro de 1954, foi admitido como Engenheiro Chefe do Escritório Técnico de Engenharia e Arquitetura da Comissão da Cidade Universitária, tornando-se seu diretor em 1955. No mesmo ano, passou a integrar o Conselho Superintendente da Comissão da Cidade Universitária da USP. Nos anos 1950, associou-se com Ernest Robert de Carvalho Mange (que também era seu assistente na FAUUSP), quando fizeram projetos para abrigar as instituições de ensino profissionalizante do Serviço Nacional da Indústria. Em 1949, foi contratado como professor assistente na cadeira de Pequenas Composições I, a convite de Zenon Lotufo (pasta funcional do docente, apud ALBUQUERQUE, 2004, p. 289). Em 1950, tornou-se professor titular da cadeira de Grandes Composições do terceiro ano, tendo por assistente Ernest Robert de Carvalho Mange, que se iniciou na docência a seu convite (SEGAWA, 2010). Entre 1954 e 1958, regeu a cadeira de Grandes Composições do quarto ano e a disciplina Plástica III a ela subordinada. Em 1958 voltou a lecionar na cadeira de Pequenas Composições I, sendo também responsável pelas disciplinas de Plástica I $-1^{\mathrm{a}}$ e $2^{\mathrm{a}}$ partes, para o primeiro e segundo anos. Após a reforma de 1962, Hélio Duarte ficou

7 A equipe chefiada por Hélio Duarte contou com Ernest Robert de Carvalho Mange, Oswaldo Gonçalves Corrêa, José Roberto Tibau e Eduardo Corona (ABREU, 2007, p. 133). Todos foram docentes da FAUUSP. 
responsável pela cadeira de Projeto I ${ }^{8}$. Quando Artigas foi afastado, em 1969, Hélio Duarte foi nomeado para substitui-lo na Cadeira de Projeto IV $\left(1^{\circ}\right.$ Livro de Atas da Congregação da FAUUSP, 1969). Permaneceu na docência até 1979, participando da criação do programa de pós-graduação, no início dos anos 1970. Foi também um dos idealizadores do Trabalho de Graduação Interdisciplinar, introduzido no curso em 1971.

Jon A. V. Maitrejean foi seu aluno na FAUUSP no primeiro ano da faculdade e destacou a importância do docente em sua formação:

Quem marca mesmo para mim, uma coisa é marcar como professor outra coisa é marcar pelas idéias, e, evidente, no nosso primeiro ano nós tínhamos professores de arquitetura, que não era o Artigas. O Artigas era do quarto ano. Mas um homem que marcou muito pelas coisas que ele colocava era o Hélio Duarte. (...) Seguramente lá [nas aulas da FAUUSP] tinha uns conteúdos ideológicos que entusiasmava a juventude, você achava então que aquilo era uma coisa tão importante que eu acho que a grande qualidade desses primeiros cursos era fazer com que você se entusiasmasse com a sua profissão (...) Nisso tinha muita importância o Hélio [Duarte] (...) (apud SODRÉ, 2009, p. 64).

No trabalho de Hélio Duarte, o caráter social da arquitetura é prioridade em suas inquietações, como atesta o seu depoimento:

Eu me interesso muito mais pelo conteúdo social de um programa do que a arquitetura desse programa. Eu acho o conteúdo social muito mais importante do que o teto sobre esse programa social. Não é daí que sou contra a arquitetura, eu acho que a arquitetura também é um jeito de ensinar. (Depoimento de Hélio Duarte a Euler Sandeville Jr. em 1985, in TAKIYA, 2009, p. 22, grifo nosso).

Hélio Duarte apresentou com Ernest Robert de Carvalho Mange um artigo para o IV Congresso Brasileiro de Arquitetos, intitulado "Contribuição ao Estudo da Arquitetura" (IAB, 1954, p. 213-216). Nele, os autores propunham revisar e modificar a estrutura dos cursos de arquitetura, defendendo que o currículo deveria tender para um conhecimento objetivo e completo do homem (indivíduo e coletividade) e da natureza (ambiente e matéria), ao invés de valorizar excessivamente os aspectos formais. A proposta compreendia, além da inclusão e modificação de disciplinas, a revisão geral dos currículos, especialmente das disciplinas de "Plástica", visando a realização prática das proposições levantadas?

8 Em publicação da FAUUSP referente a sequência de disciplinas de Desenho Industrial de 1963, Hélio Duarte também consta como docente de Desenho Industrial para o $1^{\circ}$ ano (FAUUSP, 1963).

9 De fato, as disciplinas de plástica na FAUUSP foram se transformando ao longo da década, até serem extintas em 1962, juntamente com as Cadeiras de Composição, dando lugar à sequência de Desenho Industrial e ao Grupo de Disciplinas de Projeto. 


\section{Rino Levi (1901-1965)}

Nascido em São Paulo em 1901, formou-se em arquitetura na Escola Superior de Arquitetura de Roma em 1926. Segundo Anelli (1998, p. 02), essa faculdade buscava superar a divisão entre as belas artes e o ensino politécnico, visando a formação do "arquiteto integral", no âmbito de uma modernização fiel à tradição clássica e dentro das normas tratadistas. Lá, Rino Levi foi aluno de Marcello Piacentini, responsável pela introdução do urbanismo na escola, através da disciplina Edilizia Citadina. Para Piacentini havia uma hierarquia do urbano sobre o arquitetônico, existindo entre ambos um vínculo indissolúvel. O arquiteto italiano propunha ainda a cidade polinucleada, preservando-se os centros históricos e construindo-se centros urbanos associados à expansão periférica de novos núcleos industriais e habitacionais, ao quais deveriam ser aplicados os princípios das cidades-jardim propostas por Ebenezer Howard (idem, p. 03). Na visão de Anelli, a formação de Rino Levi na Itália contribuiu para que o arquiteto construísse uma posição própria em arquitetura, coerente com as especificidades do local onde esta era produzida, de modo que seus estudos sobre Gropius e Le Corbusier não o levaram à reprodução acrítica das soluções dos mestres. De volta ao Brasil, aplicou suas concepções urbanísticas em uma proposta de um plano regulador para São Paulo. Anelli afirmou que os seus projetos de arquitetura em diversas ocasiões alcançavam dimensões urbanísticas, extrapolando o escopo dos programas propostos. Em São Paulo projetou diversos edifícios, a maior parte de grande porte, participando da modernização da paisagem da cidade. Dentre os edifícios, estão o Columbus (1934), Guarani (1936) e Prudência (1950). Em 1945, constituiu a Rino Levi Arquitetos Associados, com Roberto Cerqueira César, desenvolvendo projetos como complexos industriais, edifícios comerciais, escritórios, edifícios residenciais, casas, cinemas, hospitais, teatros, bancos. Em 1951, Luiz Roberto de Carvalho Franco juntou-se à sociedade. Esse foi o primeiro escritório de arquitetura a trabalhar exclusivamente com o projeto arquitetônico, desligando-se das atividades de construção da obra.

Rino Levi foi docente da FAUUSP entre 1954 e 1959, lecionando Grandes Composições para o $5^{\circ}$ ano. A seu convite, Roberto Cerqueira César foi contratado em 1954 como seu assistente. Em 1957, após a solicitação de afastamento de Artigas como assistente da cadeira de Pequenas Composições para o primeiro ano, Rino Levi convidou-o a ocupar a vaga de assistente na cadeira em que lecionava. A partir de 1959, o arquiteto passou a se afastar por alguns períodos da faculdade em função de uma viagem que fez à Venezuela para realizar o projeto de três hospitais, assim como colaborar como professor visitante nos ateliês de Composição Arquitetônica na Universidade Central da Venezuela (Carta de Julien Ferris, decano, a Rino Levi, de 03/02/1959). Em sua ausência, Artigas ficou responsável pela cadeira. Finalmente, pediu seu afastamento definitivo no início de 1960, alegando a necessidade de realização de outras viagens ao exterior por motivos profissionais (Carta de Roberto Cerqueira César, procurador de Rino Levi, a Luiz de Anhaia Mello, diretor da FAUUSP, de $11 / 02 / 1960)$. 


\section{Roberto Cerqueira César (19I7-2003)}

Formado na Escola Politécnica em 1940, Roberto Cerqueira César trabalhou no escritório de Rino Levi desde 1941, tornando-se seu sócio em 1944. Dentre as obras de arquitetura realizadas pelo escritório estão o Edifício Prudência (1943), o Teatro Cultura Artística (1943), o Hospital Central do Câncer (1947), o Hospital Cruzada Pró-Infância (1950), o Hospital Albert Einstein (1958) e o Centro Cívico de Santo André (1965). Após a morte de Rino Levi, os arquitetos prosseguiram com o escritório, realizando projetos como a sede da Fiesp na Avenida Paulista (BRUNA, 2003, p. 18). Em 1957, participou da equipe de Rino Levi no concurso para o Plano Piloto de Brasília, que terminou classificado em $3^{\circ}$ lugar. Além das atividades no escritório, Roberto Cerqueira César foi diretor da antiga Coordenadoria Geral do Planejamento (Cogep), atualmente denominada Secretaria Municipal de Planejamento. Presidiu e organizou a Empresa Municipal de Urbanização, Emurb, durante a gestão de Figueiredo Ferraz (1973-1974).

Na FAUUSP, Roberto Cerqueira César foi professor assistente de Rino Levi em Grandes Composições para o 5 ano entre 1954 e 1957. De 1958 a 1962, lecionou Grandes Composições para o $4^{\circ}$ ano e a disciplina de Plástica II, a ela subordinada. Foi o coordenador de uma das comissões responsáveis pela reforma curricular de 1962, que compreendia Artigas, Hélio Duarte, Joaquim Guedes, Carlos Millán, Luiz Roberto de Carvalho Franco, Lúcio Grinover, Roberto Coelho Cardozo, Rubens Maister e Miranda Maglioli. Após a Reforma de 1962, ficou responsável pelo curso de Projeto III.

\section{José Vicente Vicari (I90I-I989)}

José Vicente Vicari, assim como Rino Levi, formou-se na Universidade de Roma, na década de 1920. Entretanto, retornou ao Brasil apenas em 1947. Além de lecionar na FAUUSP, foi também docente do Mackenzie, trabalhou na prefeitura e São Paulo e, anteriormente, foi professor em Turim, na Itália.

As concepções de Anhaia Mello parecem ter exercido influência sobre o arquiteto. Em 1949, Vicari publicou na revista "Arquitetura e Engenharia" um artigo intitulado "Problemas de Urbanismo", em que o autor expunha diretrizes do urbanismo moderno apoiado no pensamento de Anhaia Mello. Em 1959, ele publicou ainda um artigo sobre o tratamento de áreas livres e áreas verdes nos Planos Diretores. A relação entre arquitetura e urbanismo era um assunto caro ao docente, que apresentou teses sobre essa questão, publicando um artigo sobre o tema em 1957 na Revista de Engenharia Municipal. No IV CBA, o arquiteto afirmou que:

Assim como Anhaia Mello, Vicari afirmava que o controle da situação econômico-

Se hoje a urbanística está intimamente ligada à arquitetura é por razões de proporções de espaços e de volumes, e dentro desta expressão podemos conceber as nossas cidades sob aspectos harmônicos de pura composição arquitetônica e não sob aspectos coreográficos de apresentação. (IAB, 1954, p. 194).

-especulativa dos terrenos era um fator primordial para a resolução dos problemas urbanos. Vicari também defendia a importância de se formar uma opinião pública capaz de pres- 
sionar o poder legislativo a dispor sobre uma planificação realizada em bases humanas, de modo democrático. Nesse sentido, assinalou a falta de apoio aos urbanistas por parte da população em prol da qual trabalhavam.

Em 1954, no IV Congresso Brasileiro de Arquitetos, apresentou dois artigos: "Sobre a Composição Arquitetônica" e "Coordenação dos Planejamentos Regionais". Ainda que não tenha encabeçado a defesa da arquitetura moderna à maneira do grupo hegemônico ligado ao IAB, fazia defesa de concepções tidas como modernas. Por exemplo, no primeiro artigo, em relação ao método de ensino, o arquiteto afirmou que:

Para o arquiteto, a Composição Arquitetônica devia ser a espinha dorsal da forma-

Os resultados desses métodos que são mais adotados nas Escolas Superiores de Arquitetura européias, enxertados no sistema de "ateliers" tão vastamente adotado em muitas Faculdades latino-americanas, de acordo com os processos de pesquisa das faculdades norte-americanas, provocando a conjunção dos professores em equipes de ensino (como já foi pelo abaixo-assinado experimentado no $2 f f l$ semestre deste ano letivo, no $5 f l$ ano da Faculdade de Arquitetura e Urbanismo de São Paulo), poderão dar, dentro do sistema ecológico brasileiro, suficientes e bons resultados. (IAB, 1954, p. 218).

ção. Todavia, antes disso, propunha que fossem destinados os dois primeiros anos do curso à preparação cultural, técnica e artística. Assim, as matérias de "Pequenas Composições" nesse período deveriam ser substituídas pela de "Desenho Arquitetônico". Apenas os três últimos seriam de caráter aplicativo, tendo como matéria-tronco a Composição Arquitetônica. Vicari defendia também a adoção de temas de "caráter prático, ao invés dos temas demasiadamente monumentais e acadêmicos, em conformidade com a vida construtiva e profissional de hoje", e com localização definida, ao invés de hipotética (IAB, 1954, p. 216). Apesar de não questionar o conceito de composição, o arquiteto defendeu ideias que seriam trabalhadas no processo de reestruturação do curso da FAUUSP. Todavia, fez uma critica ao modernismo, que considerava um "estilo contemporâneo", um modismo:

Vicari também denunciava a "inadequável estrutura das comunidades em relação

[Seguindo o processo de ensino proposto por Vicari] podemos discriminar quanto existe de original e de vantajosamente assimilado e elaborado nas formas por ele adotadas, e quanto, ao invés, sob uma aparência nova, demasiado direta e servilmente derivada de modelos abusados ou publicados por revistas em geral. Pode-se ainda assinalar as eventuais descontinuidades e desarmonias de concepcão, combatendo-se com particular vivacidade tudo quanto tenha sabor de arquitetura rotineira, comum e vulgar. (idem, p. 218)

ao progresso técnico e ao atual teor de vida no Brasil” (IAB, 1954, p. 193). De acordo com ele, o erro estava em obrigarem-se a adequar os hábitos e necessidades de vida do século XX a se desenvolverem dentro de formas do século XIX. De modo que recuperar o modelo das grandes cidades europeias anteriores à primeira guerra mundial era um equívoco (incluindo-se a "Cidade Jardim").

O autor teceu uma crítica à descentralização das cidades, "não tanto pela sua razão 
própria de ser, como problema, como pelo modo inorgânico, acidental e fragmentário que no Brasil vem se realizando" (IAB, 1954, p.194). Discutindo o crescimento das cidades, afirmou que decorriam mais de um processo de expansão do que de um espontâneo aumento da população. Sua proposta para o processo de planejamento consistia em abordar duas questões: a "ressistematização" dos centros urbanos, adaptando-os às exigências da vida moderna; e o desenvolvimento de bairros suburbanos, a ser guiado em função orgânica com o centro da cidade e em função com o plano geral da inteira área metropolitana.

Por fim, é importante considerar que Vicari chegou ao Brasil apenas em 1947, no pós-guerra, quando os debates sobre a autonomia do campo de arquitetura e urbanismo já se encontravam encaminhados e no mesmo ano em que foi fundada a faculdade de arquitetura do Mackenzie. Isso significa que entre os anos 1920 e 1940, o arquiteto estava em contato com outras vertentes da arquitetura e do urbanismo do que aquelas que mais influenciavam os profissionais de São Paulo, vivia em outro contexto social e, possivelmente, isso trouxe contribuições para os debates dos quais veio a participar no Brasil, após o seu retorno.

Vicari permaneceu na FAUUSP apenas entre agosto de 1951 e fevereiro de 1954, na Cadeira de Grandes Composições para o quarto ano. Assim como ocorreu com Elisário da Cunha Bahiana, que apresentamos a seguir, sua contratação parece ir num sentido contrário à tendência de modernização do curso impulsionada desde a criação da faculdade, e pode fazer parte do contexto conflituoso em que se deu a greve dos alunos da FAUUSP em 1951. Apesar do registro de sua presença nos eventos profissionais, contando com uma participação ativa, apresentado discussões sobre ensino, sobre arquitetura e urbanismo nas revistas especializadas, trata-se de um docente pouco lembrado e mesmo de um profissional cuja atuação em São Paulo permanece desconhecida. Fora seus próprios textos, não pudemos identificar trabalhos que abordassem a sua trajetória.

\section{Elisário da Cunha Bahiana (I89I-I980)}

Nascido no Rio de Janeiro em 1891, o arquiteto ingressou na Escola Nacional de Belas Artes em 1908, concluindo os estudos em 1920. Trabalhou como arquiteto no Rio de Janeiro entre 1920 e 1927, com os arquitetos Enoch da Rocha Lima ${ }^{10}$, Mário dos Santos Maia e Joseph Gire, além de participar da Sociedade Comercial e Construtora Ltda., com a qual realizou projetos em São Paulo, para onde se transferiu definitivamente em 1930. Iniciou-se na atividade docente em 1943, na Escola de Engenharia do Mackenzie e, a partir de 1947, atuou na Faculdade de Arquitetura daquela instituição. Dentre obras do arquiteto, estão o Viaduto do Chá, em São Paulo (1934-38), o edifício-sede do jornal A Noite, no Rio de Janeiro (um dos maiores arranha-céus da America Latina nos anos 1930), o edifício João

10 Enoch da Rocha Lima foi professor da FAUUSP entre 1953 e 1960, na cadeira de "Arquitetura Analítica", anteriormente a cargo do politécnico Bruno Simões Magro. O objetivo da disciplina, de acordo com o programa proposto para 1957 era "o estudo da morfologia dos elementos arquiteturais, como os funcionais, estruturais, construtivos e plásticos, além da análise do uso desses elementos através da história". 
Brícola (antiga sede das lojas Mappin no centro de São Paulo), o edifício Saldanha Marinho (1929), que abriga atualmente a Secretaria de Segurança Pública do Estado de São Paulo, o Jóquei Club de São Paulo, dentre outros. O arquiteto manteve-se alinhado com o movimento Art Déco. Assim como José Vicente Vicari, permaneceu na FAUUSP por um breve período, de 1951 a 1954, ano que antecedeu a aprovação do primeiro regulamento da escola. A data de desligamento de Vicari e Bahaiana da FAUUSP é a mesma: 28/02/1954.

\section{9. Ícaro de Castro Mello (1913-1986)}

Ícaro de Castro Mello, nascido em São Vicente, no Estado de São Paulo, formado no curso de Engenheiros Arquitetos da Escola Politécnica em 1935, ficou conhecido pelo projeto de inúmeros equipamentos esportivos no Brasil. Além disso, foi tido como um grande atleta, chegando a competir nas Olimpíadas de 1936, em Berlim, na modalidade de salto com vara. Pertenceu ao grupo de arquitetos que se envolveu ativamente na institucionalização da profissão de arquitetura em São Paulo. Participou da fundação do IAB, bem como de várias de suas diretorias. No período em que esse instituto apresentou a proposta de regulamentação profissional que acarretou conflitos com o CREA, Ícaro de Castro Mello era o seu presidente.

Ingressou como docente na FAUUSP em 1950, nela permanecendo até março de 1955. Nesse período, foi assistente da cadeira de "Pequenas Composições" para o primeiro ano entre 1950 e 1953. Em 1954, lecionou "Grandes Composições" para o quarto ano, tendo por assistente seu colega Oswaldo Corrêa Gonçalves.

A partir de 1954, integrou a equipe encarregada de projetar os edifícios do novo campus da USP, liderada por Anhaia Mello. Ícaro de Castro Mello ficou responsável pelo setor esportivo. Projetou também a Faculdade de Educação Física dessa universidade (FICHER, 2005, p. 287).

Fora da faculdade, manteve intensas relações profissionais com outros de seus docentes. Associou-se a Oswaldo Corrêa Gonçalves, arquiteto santista, em 1948. Em 1952, colaborou com Zenon Lotufo e Roberto Cerqueira César no projeto da Associação Cristã de Moços (FICHER, 2005, p. 286).

\section{Io. Oswaldo Corrêa Gonçalves (1917-2005)}

Oswaldo Corrêa Gonçalves formou-se engenheiro-arquiteto em 1941 e engenheiro civil em 1945, realizando ambos os cursos na Escola Politécnica. É considerado um dos pioneiros da arquitetura moderna em Santos, sua cidade natal. Teve uma intensa atividade profissional, contando com diversos colaboradores (FICHER, 2005, p. 325). Projetou obras como o Teatro Municipal de Santos (1968), o Clube Atlético Santista (1947), o Estádio do Guarani Futebol Clube em Campinas, com Ícaro de Castro Mello (1948), e o Passo Municipal de Guarujá, com Heitor Ferreira de Souza (1960), entre outros.

Participou do Convênio Escolar sob direção de Hélio de Queiroz Duarte entre 1949 e 1952. Assim como seus colegas, atuou na institucionalização da profissão de arquiteto: foi um dos fundadores do IAB-SP e defendeu a criação de uma escola autônoma de arqui- 
tetura. Foi um dos organizadores do IV CBA, em 1954. Trabalhou na FAUUSP entre 1954 e 1956. Não pudemos identificar com precisão em que cadeira lecionou. De acordo com Ficher (2005, p. 326), foi assistente na Cadeira de Grandes Composições para o $4^{\circ}$ ano. Conforme documentos da reitoria da USP, o arquiteto foi convocado para lecionar como assistente de Ícaro de Castro Mello na cadeira de Pequenas Composições I em 1955. . Em 1969, participou da criação da Faculdade de Arquitetura de Santos.

\section{Carlos Barjas Millán (1927-1964)}

Carlos Millán formou-se na primeira turma de arquitetura do Mackenzie, em 1951. Embora o curso daquela faculdade tivesse uma orientação acadêmica e anti-moderna, em decorrência da visão de seu fundador, Christiano Stockler das Neves, Millán e muitos de seus colegas contemporâneos, como Paulo Mendes da Rocha, Luiz Roberto de Carvalho Franco e Jorge Wilheim combateram essa orientação. Foi com esse intuito que os jovens estudantes fundaram o Diretório Acadêmico da Faculdade de Arquitetura do Mackenzie, DAFAM. Esses e outros alunos do Mackenzie editaram, no mesmo período, a revista Pilotis, que procurava trazer a referência da arquitetura moderna para a faculdade. Assim, podemos considerar que a despeito do caráter centralizador e autoritário de Stockler das Neves na administração da faculdade, seus estudantes, desde cedo, envolveram-se com a arquitetura moderna e assumiram sua causa em São Paulo.

No movimento estudantil, Millán participou da Juventude Universitária Católica, JUC e, posteriormente, da Ação Popular (MATERA, 2005, p. 31). Em 1950, alugou um escritório com Luiz Roberto de Carvalho Franco e Sidney Fonseca em que, além de desenvolver projetos, mantiveram um grupo de assistência a mutirões. Em 1952, inaugurou, com os arquitetos Miguel Forte, Jacob Ruchti, Plínio Croce, Roberto Aflalo, todos mackenzistas, além do chinês Chen Y Hwa, a loja de móveis projetados Branco \& Preto, que teve curta duração. Ao mesmo tempo, envolveu-se com a Ordem dos Dominicanos, na comunidade de Perdizes, por meio da qual trabalhou com a Unilabor, empresa de mobiliário moderno auto-gerida por trabalhadores de baixa renda e que teve à frente o designer Geraldo de Barros.

Carlos Millán pertenceu à direção do IAB entre 1959 e 1961 e foi seu tesoureiro entre 1962 e 1963. Para a gestão de 1964-1965, concorreu a presidente, mas perdeu por uma pequena diferença para a chapa tida como de "direita" de Alberto Botti. Entre 1955 e 1959, compartilhou um escritório com Joaquim Guedes, outro arquiteto ligado aos dominicanos, que trabalhou desde cedo com o Padre Lebret, formado na FAUUSP em 1954 e contratado como docente da mesma faculdade em 1958, como parte do que viria a ser o Departamento de Tecnologia. Segundo Matera (2005, p. 94), a partir de 1955, Carlos Millán conheceu Artigas e aproximou-se do grupo de arquitetos da FAUUSP, afastando-se dos colegas do Mackenzie. Ainda assim, foi nesta faculdade que iniciou a atividade docente, em 1957.

Em 1959, foi convidado por Roberto Cerqueira César a lecionar Grandes Composições para o quarto ano. De acordo com Matera (idem, p. 94), os alunos da FAUUSP reivindicavam professores próximos às pesquisas contemporâneas de arquitetura e iniciaram uma greve que se encerrou com a contratatação de Millán. O arquiteto também projetou o edifício do curso de Letras da FFCL na Cidade Universitária, entre 1961 e 1962. Sua proposta inscrevia-se na "rua de convivência das humanas", que integrava desde o edifício dos 
cursos de História e Geografia até a FAUUSP.

Em 1962, foi o relator de uma comissão de estudo da reforma de ensino que incluía, além dele próprio, Jon Maitrejean, Lúcio Grinover e Gian Carlo Gasperini, apresentando um documento intitulado "O atelier na formação do arquiteto". Seus antigos alunos o recordam como um professor sério e atento aos detalhes. Sérgio Ferro, formado em 1961, afirmou:

Que eu me lembre, as visitas [a obras] que a gente fazia com o Millán eram aulas de sabedoria, de como resolver um problema, de como encontrar (...) sempre a solução racionalmente exata. (...) o guia dele era a razão. (...) O Millán nunca foi um professor vedete, entretanto era o que mais vinha pra prancheta e discutia com a gente em detalhes (apud MATERA, 2005, p. 98).

Em decorrência de seu envolvimento com a Ação Popular, Carlos Millán passou a receber telefonemas de ameaças em 1964, após o golpe militar, e o arquiteto procurou afastar-se de São Paulo. Em 05 de dezembro daquele ano, foi morto com sua esposa e três de seus cinco filhos, não pelos militares, mas em um acidente de automóvel, enquanto voltava de uma visita a uma fazenda em que deveria iniciar o projeto de uma reforma. No acidente, apenas a filha mais velha sobreviveu. Em 1965, recebeu uma homenagem na 8a Bienal de São Paulo, que contou com textos de Artigas e de Alceu Amoroso Lima.

\section{I2. Jon Andoni Vergareche Maitrejean (I929)}

Jon Andoni Vergareche Maitrejean, espanhol, de uma família que migrou para o Brasil para escapar da ditadura franquista, formou-se na FAUUSP em 1953. Em 1954, foi o primeiro ex-aluno da faculdade contratado como docente, passando a trabalhar como assistente de Abelardo de Souza na cadeira de Grandes Composições para o terceiro ano. Como estudante, havia trabalhado com Abelardo de Souza desde o segundo ano da graduação e foi por indicação de seu tutor que Jon Maitrejean elaborou os desenhos da Casa de Vidro, de Lina Bo Bardi (ALMEIDA \& TEIXEIRA, 2005). Em 1955, já formado, também colaborou no escritório de Abelardo de Souza.

Em seguida, começou a trilhar sua própria carreira profissional, em parceiria com Daisy Igel, que desde 1954 era assistente de Roberto Coelho Cardozo na cadeira de Arquitetura da Paisagem da FAUUSP. Juntos projetaram, dentre outros, o terminal da Companhia Ultragaz. Seus projetos sempre expressavam uma preocupação com a funcionalidade, com os materiais empregados, frequentemente em estado bruto, e com a industrialização da construção, procurando adotar elementos pré-moldados e produtos industrializados. Manteve interesse permanente pelo binômio "racionalização dos componentes e agilidade do processo construtivo" (idem, ibidem).

Em 1969, foi cassado da FAUUSP, assim como Artigas e Paulo Mendes da Rocha. A partir de então passou a trabalhar para grandes empresas, como Duratex (1969-1972), Serete Engenharia (1972-1973) e Quatro Rodas Empreendimentos Turísticos (1974), para as quais desenvolveu projetos de grande porte, como hotéis, indústrias e estádios. Em 1975, associou-se com Georges Sallout, tendo projetado, dentre outros, o Crown Plaza Hotel, a sede da Construtora Passareli, ambos de 1975. Também desenvolveram inúmeros projetos de supermercados. Após a Lei de Anistia, Jon Maitrejean retornou à FAUUSP para receber 
homenagens com os demais professores cassados na década anterior. Não pudemos identificar, ao longo da pesquisa, documentação referente à sua atuação como docente ou em outros meios institucionais.

\section{Luiz Roberto de Carvalho Franco (1926-200I)}

Formado pelo Mackenzie em 1951, Luiz Roberto de Carvalho Franco foi um dos estudantes daquela escola que buscaram contestar sua orientação acadêmica. No terceiro ano da faculdade, ele e Carlos Millán, seu colega de turma, estagiaram no escritório de Abelardo de Souza. No mesmo ano, os dois estudantes, mais Sidney Fonseca, inscreveram-se no I concurso de estudantes da Bienal de São Paulo, obtendo o primeiro lugar. Em seguida, foi convidado por Rino Levi e Roberto Cerqueira César a integrar a equipe do escritório Rino Levi e Arquitetos Associados Ltda., onde trabalhou até 2001, ano de seu falecimento.

Integrou o corpo docente da FAUUSP a partir de 1958, por indicação de Rino Levi e Roberto Cerqueira César. Inicialmente, ocupou o cargo de assistente de Roberto Cerqueira César na cadeira de Grandes Composições para o quarto ano (SANT'ANNA, 2001). Após a reforma de 1962, Carvalho Franco passou a lecionar na sequência de Desenho Industrial até sua saída da escola, em 1966.

\section{I4. Plínio Croce (I92I-I984)}

Plínio Croce formou-se na primeira turma de arquitetura do Mackenzie, junto com colegas como Carlos Millán, Paulo Mendes da Rocha, Luiz Roberto de Carvalho Franco, Jorge Wilheim, Roberto Aflalo, Jacob Ruchti, Miguel Forte. Jovem arquiteto, associou-se a Roberto Aflalo e Gian Carlo Gasperini, que fundaram a Croce, Aflalo \& Gasperini Arquitetos Ltda. em 1962, que foi renomeada após seu falecimento, em 1984, para Aflalo e Gasperini Arquitetos.

Não pudemos identificar com precisão em qual cadeira Plínio Croce lecionou na FAUUSP. Contratado em 1952, permaneceu na escola até 1967. Em ofício de 1955, Plínio Croce consta como assistente de Hélio Duarte em Pequenas Composições para o $2^{\circ}$ ano. Araken Martinho, aluno da FAUUSP entre 1952 e 1956 lembra de ter sido aluno de Plínio Croce em seu terceiro ano (1954), na cadeira de Grandes Composições (apud SODRÉ, 2009, p. 123.). Entretanto, não pudemos identificar que cadeira ocupou naquele momento.

\section{Paulo Archias Mendes da Rocha (1928)}

Provavelmente, Paulo Mendes da Rocha é o arquiteto ainda atuante em São Paulo de maior reconhecimento. Nascido em Vitória, Espírito Santo, é filho de Paulo de Menezes Mendes da Rocha. Este foi professor catedrático da Escola Politécnica e seu diretor entre 1943 e 1947, participando, portanto, do processo de criação da FAUUSP.

Paulo Mendes da Rocha formou-se pelo Mackenzie em 1954. Foi contratado como docente da FAUUSP em outubro de 1960 a convite de Artigas e também foi aposentado compulsoriamente em 1969, retornando à universidade em 1980, lá permanecendo até 1998. 
ANEXOS 


\title{
ANEXO A - ESTRUTURAS CURRICULARES DA FAU-USP (1948-1962)
}

I. Lei ${ }^{\circ}$ Io4 de 2 I de junho de 1948

Dispõe sobre a criação, na Universidade de São Paulo, da Faculdade de Arquitetura e Urbanismo.

\author{
LEI N: 104, DE 21 DE JUNHO DE 1948
}

Dispõe sôbre a criação, na Universidade de São Paulo, da Faculdade de Arquitetura e Urbanismo.

A Ássembléia Legislativa do Estado de São Paulo decreta e eu, Francisco Alvares Florence, na qualidade de seu Presidente, promulgo, nos têrmos do Artigo 25, parágrafo único, da Constituição Estadual, a seguinte lei:

Art. Is - É criada na Universidade de São Paulo a Faculdade de Arquitetura e Urbanismo.

Art. $2 \circ$ - A Faculdade de Arquitetura e Urbanismo da Universidade de São Paulo, terá as seguintes finalidades:

a) ministrar o ensino da Arquitetura e Urbanismo, visando a formação de profissionais altamente habilitados;

b) realizar estudos e pesquisas nos vários domínios técnicos e artísticos que constituem objeto de seu ensino.

Art. 30 - A Faculdade manterá dois cursos seriados, a saber:

a) Curso de Arquitetura;

b) Curso de Urbanismo.

Parágrafo único - o Curso de Arquitetura, acessível aos portadores de certiticados de licença do ciclo colegial clássico ou científico - mediante prestação de concurso vestibular, será de cinco anos; o Curso de Urbanismo, acessível aos portadores de diplomas de engenheiro-arquiteto ou engenheiro civil, mediante prestação de concurso vestibular, será de dois anos.

Art. 4\% - A Faculdade de Arquitetura e Urbanismo compreenderá as seguintes disciplinas, providas as cadeiras por professo res catedráticos, nos têrmos da legislação em vigor:

1 - Matemática Superior

2 - Geometria Descritiva e Aplicações

3 - Mecânica Racional

4 - Topografia, Elementos de Astronomia de posição

5 - Resistência dos Materiais e Estabilidade das Constru ções

6 - Materiais de construção

7 - Hidráulica; Hidráulica Urbana e Saneamento

8 - Construções Civis, Organização do Trabalho e Prática Profissional; Higiene das Habitações

9 - Concreto simples e armado

10 - Elementos de Mecânica dos solos. Fundações 
$-2-$

11 - Grandes Estruturas

12 - Economia Política e Estatística Aplicada. Organizações Administrativas

13 - Física Aplicada

14 - Arquitetura Analítica

15 - Teoria da Arquitetura

16 - Composição Arquitetônica - Pequenas composições

17 - Composição Arquitetônica - Grandes composições

18 - Arquitetura no Brasil

19 - Urbanismo

20 - Arquitetura paisagista

21 - História da Arte e Estética

22 - Planologia. A evolução urbana

23 - Planologia. Análise e sociologia urbanas

24 - Planologia. Administração municipal. Serviços de utilidade pública

25 - Planologia. Teoria e prática dos planos reguladores

26 - Nomografia

27 - Legislação e Contabilidade

28. - Desenho Artístico

29 - Composição decorativa

30 - Plástica

Parágrafo único - As disciplinas de números 26 a 30 serão sujeitas ao regime de "aulas" nos têrmos do regulamento da Escola Politécnica da Universidade de São Paulo, enquanto não entrar em vigor o Regulamento da Faculdade de Arquitetura e Urbanismo.

Art. 5\% - A seriação do Curso de Arquitetura será a seguinte:

PRIMEIRO ANO

1 - Matemática Superior

2 - Geometria Descritiva e aplicações

3 - Arquitetura analítica

4 - Composição de Arquitetura. Pequenas composições

5 - Nomografia

6 - Desenho Artístico

7 - Plástica

SEGUNDO ANO

1. - Mecânica Racional

2 - Materiais de Construção

3 - Topografia. Elementos de astronomia de posição

4 - Teoria da Arquitetura

5 - Composição de Arquitetura. Pequenas composições

6 - Desenho artístico

7 - Plástica

TERCEIRO ANO

1 - Resistência dos materiais e estabilidade das construções

2 - Construções civis. Organização do trabalho e práti- 
ca profissional. Higiene das habitações

3 - Física aplicada

4 - Mecânica dos solos. Fundações

5 - Composição de arquitetura. Grandes composições

6 - Composição decorativa

7 - Plástica

QUARTO ANO

1 - Concreto simples e armado

2 - Economia política. Estatística aplicada. Organizações administrativas

3 - Hidráulica. Hidráulica Urbana e Saneamento

4 - Grandes estruturas

5 - Composição de Arquitetura. Grandes composições

6 - Legislação e contabilidade

7 - Composição decorativa

8 - Plástica

QUINTO ANO

1 - História da Arte. Estética

2 - Arquitetura do Brasil

3 - Urbanismo

4 - Arquitetura paisagista

5 - Composição de arquitetura. Grandes composições

6 - Composição decorativa

7 - Plástica

Art. 6\% - A seriação do Curso de Urbanismo será a seguinte:

PRIMEIRO ANO

1 - Planologia

I - A evolução urbana (1a. parte)

2 - Planologia

II - Análisè urbana

3 - Planologia

III - Teoria e Prática dos planos reguladores (1a. parte)

4 - Arquitetura paisagista

5 - Desenho artístico

6 - Plástica

SEGUNDO ANO

1 - Planologia

I - A evolução urbana (2a. parte)

2 - Planologia

II - Análise e sociologia urbana (2a. parte) 
$-4-$

3 - Planologia

III - Administração municipal. Serviços de utilidade pública

4 - Planologia

IV - Teoria e Prática dos planos reguladores

(2a. parte)

5 - Composição decorativa

6 - Plástica

Art. 7\% - 0 número das disciplinas de cada ano será alterado, assim como a sua seriação, por proposta do Conselho Técni co Administrativo e aprovação do Conselho Universitáriō ouvida a Congregação da Faculdade.

Art. 8\& - 0 concurso para a admissão aos cursos de Arquitetura e Urbanismo será regido pela legislação em vigor para a Faculdade de Arquitetura da Universidade do Brasil.

Art. 98 - Aos alunos que concluirem o curso de Arquitetura conferir-se-á o gráu de Arquiteto, e aos que concluirem o curso de Urbanismo, o gráu de Urbanista.

Parágrafo único - 0 título de doutor será conferido ao candidato que, dois anos pelo menos depois de graduado, defender tese original de notável valor.

Art.10e - Dentro do prazo de um ano, a contar da abertura dos cur sos, o Diretor da Faculdade apresentará ao Conselho Uní versitário, por intermédio do Reitor, um ante-projeto de Regulamento da Faculdade.

Parágrafo único - Enquanto não estiver em vigor o Regulamento da Faculdade, nos têrmos do presente artigo, reger-se-á a Faculdade de Arquitetura e Urbanismo pelo Regulamento da Escola Politécnica da Universidade de São Paulo, naquilo em que the for aplicável, e, subsidiàriamente, pelo Regulamento da Faculdade de Arquitetura da Universidade do Brasil.

Art.1lo - No ano letivo de 1948 funcionará apenas o primeiro ano do Curso de Arquitetura da Faculdade.

Art.12: - 0 primeiro ano do Curso de Urbanismo deverá ser instala do no ano letivo de 1949.

Art.13: - A Escola Politécnica de São Paulo não concederá novas matriculas no seu curso de Engenheiros Arquitetos, o qual será, gradativamente extinto.

Art.14\% - Até que a lei providencie por outro modo as disciplinas dos cursos da Faculdade de Arquitetura e Urbanismo serão regidas em ordem preferencial. 
2. Lei $\mathrm{n}^{\circ} 3.233$, de 27 de outubro de 1955

Dispõe sôbre o regulamento da Faculdade de Arquitetura e Urbanismo, da Universidade de São Paulo, criada pela Lei n. 104, de 21-6-48, e dá outras providências

\section{TÍTULO I}

Da finalidade e organização didática da Faculdade

\section{CAPÍTULO I}

Dos fins da Faculdade

Artigo $1^{\circ}$ - A Faculdade de Arquitetura e Urbanismo da Universidade de São Paulo, criada pela Lei n. 104, de 21 de junho de 1948, tem por finalidade:

I - ministrar o ensino superior de Arquitetura e Urbanismo tendo em vista a habilitação profissional de arquitetos e urbanistas; e

II - realizar estudos e pesquisas nos vários dominios que constituem objeto de seu ensino.

\section{CAPÍTULO II}

Da organização didática

Artigo 2. - - A Faculdade manterá 2 (dois) cursos seriados, a saber:

I - Curso de Arquitetura; e

II - Curso de Urbanismo

Parágrafo $1 .^{\circ}$ - O Curso de Arquitetura, acessível mediante concurso de habilitação aos portadores de certificado de licença do ciclo colegial, clássico ou científico e diploma ou certificado de outros cursos que o substituam na forma da lei, será de 5 (cinco) anos.

Parágrafo 2..$^{\circ}$ - O Curso de Urbanismo, acessível aos portadores de diploma de arquiteto ou engenheiro civil, será de 2 (dois) anos, realizando-se concurso se o número de candidatos exceder o das vagas.

\section{CAPÍTULO III}

Das cadeiras

Artigo $3 .^{\circ}$ - O ensino nos cursos da Faculdade compreenderá as seguintes cadeiras, que abrangem as disciplinas determinadas pelo artigo $4 .^{\circ}$ da Lei $n$. 104, de 21 de junho de 1.948:

Cadeira n. 1 - Cálculo Diferencial e Integral. Geometria Analítica. Nomografia.

Cadeira n. 2 - Geometria Descritiva e Aplicações.

Cadeira n. 3 - Mecânica.

Cadeira n. 4 - Física Geral e Aplicada.

Cadeira n. 5 - Materiais de Construção.

Cadeira n. 6 - Resistência dos Materiais. Estabilidade das Construções.

Cadeira n. 7 - Estruturas Correntes de Madeira Metálicas e de Concreto Simples e Armado. 
Cadeira n. 8 - Grandes Estruturas.

Cadeira n. 9 - Técnica das Construções. Organização dos Trabalhos e Prática Profissional. Higiene dos Edifícios. Noções de Mecânica dos Solos. Fundações.

Cadeira n. 10 - Hidráulica. Hidráulica Urbana e Saneamento.

Cadeira n. 11 - Topografia. Elementos de Astronomia de Posição.

Cadeira n. 12 - Noções de Economia Política. Estatística Aplicada. Organização Administrativa. Legislação e Contabilidade Específica.

Cadeira n. 13 - Arquitetura Analítica.

Cadeira n. 14 - Teoria da Arquitetura.

Cadeira n. 15 - História da Arte. Estética.

Cadeira n. 16 - Composição de Arquitetura Pequenas Composições I Desenho Arquitetônico, Plástica I

Cadeira n. 17 - Composição de Arquitetura Pequenas Composições II Plástica II.

Cadeira n. 18 - Composição de Arquitetura Grandes Composições I Plástica III.

Cadeira n. 19 - Composição de Arquitetura. Grandes Composições II.

Cadeira n. 20 - Arquitetura no Brasil.

Cadeira n. 21 - Desenho Artístico.

Cadeira n. 22 - Composição Decorativa.

Cadeira n. 23 - Urbanismo.

Cadeira n. 24 - Planologia I Evolução Urbana.

Cadeira n. 25 - Planologia II Análise e Socilogia Urbanas.

Cadeira n. 26 - Planologia III Teoria e Prática dos Planos Reguladores.

Cadeira n. 27 - Planologia IV Administração Municipal Serviços de Utilidade Pública.

Cadeira n. 28 - Arquitetura Paisagística.

Cadeira n. 29 - Matéria Legal Legislação. Ética Profissional.

(...)

Artigo 6. ${ }^{\circ}$ - Fica criado, anexo à cadeira de Urbanismo, do Curso de Arquitetura, um Centro de Pesquisas e Estudos urbanisticos, sob a direção do professor da cadeira.

Êste Centro (C. P. E. U.) destina-se:

I - a realizar pesquisas, análises e inquéritos preliminares à execução de planos urbanísticos parciais ou gerais;

II - a organizar planos diretores para os municípios que o desejarem;

III - a realizar planos e estudos relativos à habitação, uso da terra, regulamento e programas; IV - à prática e exercícios dos alunos da cadeira e do urso de Urbanismo da Faculdade: e

V - à propaganda educação e divulgação, de forma a facilitar a solução dos problemas urbanísticos.

Parágrafo único - O Diretor do Centro proporá ao Conselho Técnico e Administrativo o contrato de professôres nacionais estrangeiros, urbanistas, pesquisadores desenhistas e outros elementos necessários aos trabalhos na forma e dentro do estabelecido no Regimento Interno.

\section{CAPÍTULO IV}

Da seriação dos cursos

Artigo 7. ${ }^{\circ}$ - A seriação das matérias do Curso de Arquitetura será a seguinte:

1. ${ }^{\circ}$ ano:

1 - Cálculo Diferencial e Integral. Geometria Analítica. Nomografia. 
2 - Geométria Descritiva e Aplicações.

3 - Arquitetura Analítica.

4 - Composição de Arquitetura Pequenas Composições I Desenho Arquitetônico.

5 - Desenho Artístico.

6 - Topografia. Elementos de Astronomia de Posição.

2. ${ }^{\circ}$ ano:

1 - Cálculo Diferencial e Integral. Geometria Analítica. Nomografia.

2 - Mecânica.

3 - Física Geral e Aplicada.

4 - Teoria da Arquitetura.

5 - Composição de Arquitetura. Pequenas Composições I Plástica I.

6 - Desenho Artístico.

3. ${ }^{\circ}$ ano:

1 - Resistência dos Materiais. Estabilidade das Construções.

2 - Técnica das Construções. Organização dos Trabalhos e Prática Profissional. Higiene dos Edifícios. Noções de Mecânica dos Solos. Fundações

3 - Materiais de Construção.

4 - Composição de Arquitetura. Pequenas Composições II Plástica II.

5 - Composição Decorativa.

$4 .^{\circ}$ ano:

1 - Estruturas Correntes de Madeira, Metálicas e de Concreto Simples e Armado.

2 - Noções de Economia Política. Estatística Aplicada Organização Administrativa Legislação e Contabilidade Específica.

3 - Hidráulica. Hidráulica Urbana e Saneamento.

4 - Técnica das Construções. Organização dos Trabalhos e Prática Profissional. Higiene dos Edifícios. Noções de Mecânica dos Solos Fundações.

5 - Composição de Arquitetura. Grandes Composições I Plástica III.

6 - Composição Decorativa.

5. ${ }^{\circ}$ ano:

1 - Grandes Estruturas

2 - Arquitetura no Brasil.

3 - Urbanismo.

4 - Arquitetura Paisagística.

5 - Composição de Arquitetura. Grandes Composições II.

6 - História de Arte. Estética.

Artigo 8. ${ }^{\circ}$ - A seriação das matérias do Curso de Urbanismo será a seguinte:

$1 .^{\circ}$ ano:

1 - Arquitetura Paisagística.

2 - Planologia I Evolução Urbana.

3 - Planologia II Análise e Sociologia Urbanas.

4 - Planologia III Teoria e Prática dos Planos Reguladores.

5 - Matéria Legal. Legislação. Etica Profissional.

2. ${ }^{\circ}$ ano:

1 - Planologia I Evolução Urbana.

2 - Planologia II Análise e Sociologia Urbanas. 
3 - Planologia III Teoria e Prática dos Planos Reguladores.

4 - Planologia IV Administração Municipal. Serviços de Utilidade Pública.

[Disponível em: http://www.al.sp.gov.br/repositorio/legislacao/lei/1955/lei-3233-

27.10.1955.html]

3. Portaria $n^{\circ}$ o9 de 22 de dezembro de 1961

UNIVERSIDADE DE SÃO PAULO

FACULDADE DE ARQUITETURA E URBANISMO

(ANEXO 2)

PORTARIA Ne 9 DE 22 DE DEZEMBRO DE 1961

Fixa o "curriculum" padrão dos cursos normais da Faculdade de Arquitetura e Urbanismo da Universidade de São Paulo.

F.A.U.U.S.P.

-1962- 
PORTARIA No 9 DE 22 DE DEZEMBRO DE 1961

Fixa o "curriculum" padrão dos cursos normais da Faculdade de Arquitetura e Urbanismo da Universidade de São Paulo.

O DIRETOR DA FACULDADE DE ARQUITETURA E URBANISMO DA UNIVERSIDADE DE SÃO PAULO, nos têrmos do $\S 20$ do artigo lo do De creto ne 34.017, de 21 de dezembro de 1958 e de acôrdo com o decí dido pelo Conselho Universitário da Universidade de São Paulo, funcionando como Cong̀regação do Instituto, em sessão de 21 de de zembro de 1961.

RESOLVE:

Artigo 10 - Fica aprovado o "curriculum" padrão dos cursos normais da Faculdade de Arquitetura e Urbanismo da Univer sidade de São Paulo, constante do anexo Regimento Interno.

Artigo 2e - Esta Portaria entrará em vigor na data de sua publicação.

Artigo 3e - Revogam-se as disposições em contrário.

\section{REGIMENTO INTERNO}

Artigo 18 - Os cursos normais da Faculdade de Arqui tetura e Urbanismo da Universidade de São Paulo, obedecerão ao se guinte "curriculum" padräo: 
2

\section{IP ANO}

1 - Cálculo Diferencial e Integral. Geometria Analítica. Nomografia.

2 - Geometria Descritiva e Aplicações.

3 - Física Geral e Aplicada (1a. parte).

4 - Topografia. Elementos de Astronomia de Posição.

5 - Materiais de Construção (Construção I) _..

6 - História da Arte. Estética.

7 - Composição de Arquitetura.Pequenas Composições I. (1a.Parte).

8 - Desenho Arquitetônico (Disciplina subordinada).

9 - Desenho Artístico (1a. parte).

28 ANO

1 - Mecânica.

2 - Física Geral e Aplicada (2a. parte).

3 - Técnica das construções. Organização dos Trabalhos e Prática Profissional. Higiene dos Ediff́ios. Noções de Mecânica dos Solos. Fundações.(Construção II)。

4 - Arquitetura Analítica (1a. parte).

5 - Composição de Axquitetura. Pequenas Composições I. (2a parte).

6 - Plástica I (Disciplina subordinada).

7 - Desenho Artíst10o (2a. parte).

30 ANO

1 - Resistência dos Materiais. Estabilidade das Construçōes 。

2. - Técnica das Construgões. Organdzaçäo dos Trabalhos e Prática Profissional. Higiene dos EAlfílos. Noções de Mecânica dos Solos. Fundaçôes.(Coristrução III)

3 - Hidráulica. Hidráulioa Urbana e Sameamento.

4 - Arquitetura Analitica (2a. parte).

5 - Composição de Arqultetura. Pequenas Composiçôes II.

6 - Plástica II (Disciplina subordinada). 
7 - Composição Decorativa.

8 - Arquitetura Paisagística.

40 ANO

1 - Estruturas Correntes de Madeira, Metálicas e de Concre to Simples e Armado.

2. - Grandes Estruturas.

3 - Teoria da Arquitetura.

4 - Urbanismo ( $1 a_{\circ}$ ' parte).

5 - Composição de Arquitetura. Grandes Composições I.

5. ANO

1 - Noções de Economia Política. Estatística Aplicada. Or ganização Administrativa. Legislação e Contabilidade Especifica。

2 - Arquitetura no Brasil.

3 - Urbanismo (2a. parte)。

4 - Composição de Arquitetura. Grandes Composições II. 
ANEXO B - CURRICULO PLENO DA FAUUSP PROPOSTO EM 1962

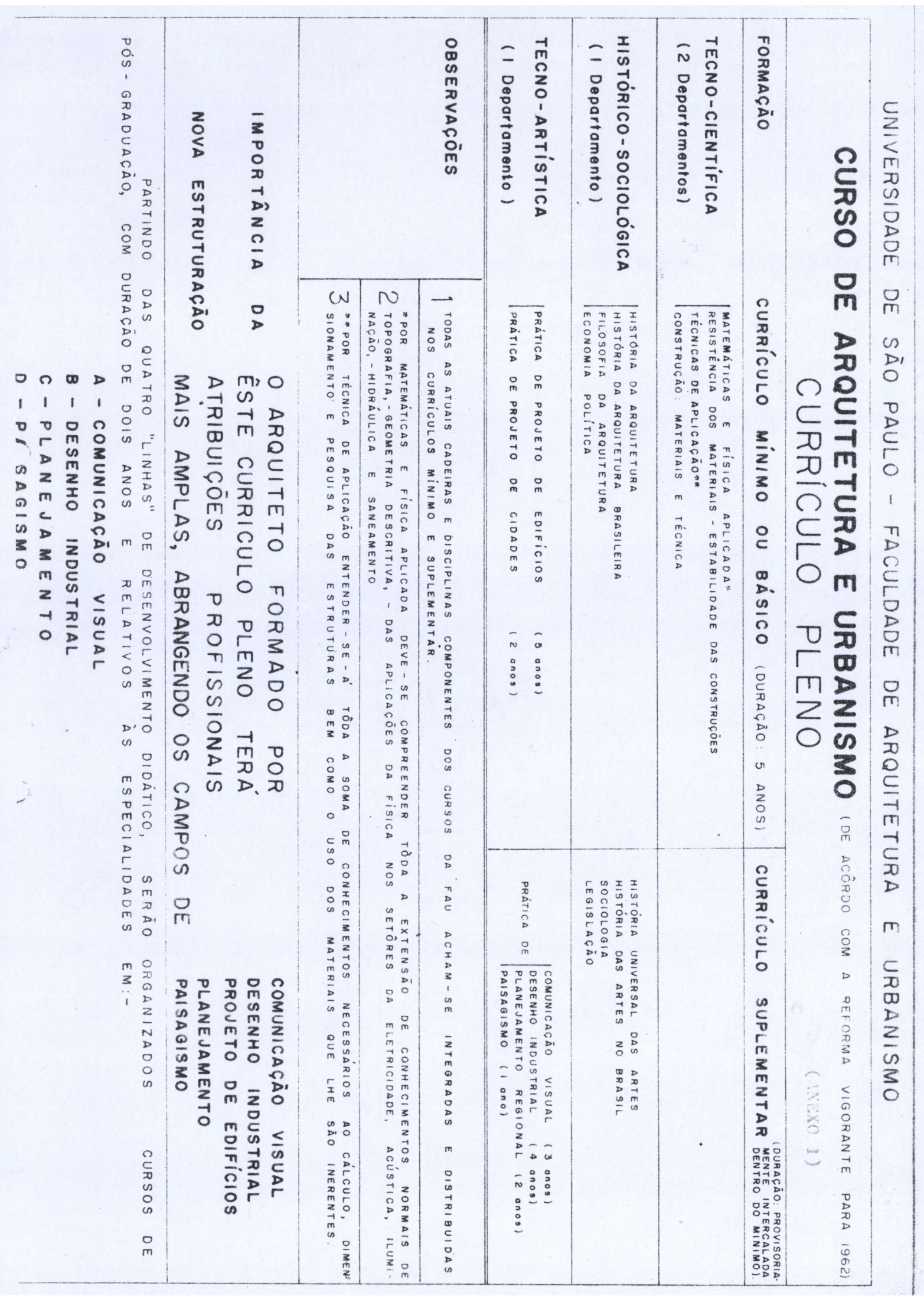




\section{CRÉDITOS DAS FIGURAS}

Capítulo or - A formação do campo profissional de arquitetura e urbanismo em São Paulo e a construção da relação entre arquitetura e urbanismo na FAUUSP.

Figura oI - Jantar comemorativo da fundação do IAB-SP. Artigas, sentado, é o terceiro da direita para a esquerda e Eduardo Kneese de Mello, sócio n 01 do IAB, está de terno branco. In: Módulo, Edição Especial, 1985, p. 30.

Capítulo 02 - O papel de Anhaia Mello na criação da FAUUSP.

Figura 02 - Árvore do Urbanismo de Anhaia Mello. In: FELDMAN, 2005, p. 60.

Figura 03 - Plano de Avenidas. Francisco Prestes Maia e João Florence de Ulhôa Cintra, 1930.

Figura 04 - Homenagem a Anhaia Mello pela criação da FAUUSP, agosto de 1948. Arquivo Oswaldo Corrêa Gonçalves. In: FICHER, 2005, p. 253.

Figura 05 - Plano Diretor de Santa Rita do Passa Quatro realizado pelo CPEU. Zoneamento Proposto. In: CPEU, 1958 (mimeo).

Capítulo o3 - Artigas e a formação do campo de arquitetura em São Paulo

Figura o6 - Retrato de Artigas em sua Carteira de Identificação, em 1934. Pasta Funcional do Docente. Arquivo Histórico da Escola Politécnica.

Figura 07 - Artigas na Escola Politécnica em 1936. In: Módulo, Edição Especial, 1985, p. 26. Figura o8 - Artigas. Trabalho do estudante do curso de engenheiros arquitetos, entre 1933 e 1937. In: Módulo, Edição Especial, 1985, p. 27.

Figura 09 - Artigas. Homem Sentado, 10 de agosto de 1938. Curso livre de desenho da Escola de Belas Artes de São Paulo. Fundação Vilanova Artigas. In: FICHER, 2005, p. 293.

Figura Io - Artigas. Mulher nua, sentada segurando os joelhos, novembro de 1939. Curso livre de desenho da Escola de Belas Artes de São Paulo. Fundação Vilanova Artigas. In: FICHER, 2005, p. 293.

Figura II - Artigas. Maquete do Projeto para o Paço Municipal de São Paulo. Artigas e Warchavchik, 1939. In: Módulo, Edição Especial, 1985, p. 27.

Figura I2 - Croquis para a FAUUSP. In: Módulo, Edição Especial, 1985, p. 33.

Figura I3 - Almoço no Hotel Excelsior, mobilização pela fundação da FAUUSP. In: FICHER, 2005, p.252. 
Capítulo o4 - A FAUUSP e o "plano" como a interface entre arquitetura e urbanismo.

Figura 14 - Tony Garnier. La Cité Industrielle: Zoneamento, 1904. In: PAWLOWSKI, 1993, p. 62.

Figura 15 - Le Corbusier. Une Ville Contemporaine, 1922. In: LE CORBUSIER, 2000, p. 162.

Figura I6 - Artigas e Carlos Cascaldi. Rodoviária de Londrina, 1948-1952. In: SUZUKI, 2000, p.168.

Figura I7 - Artigas e Carlos Cascaldi. Edifícios Autolon e Cine Ouro Verde, Londrina, 19481952. In: SUZUKI, 2000, p. 179.

Figura I8 - Artigas e equipe. Projeto de Brasília: Vista Aérea, 1957. In: Módulo, 1957.

Figura I9 - Artigas e equipe. Projeto de Brasília: Plano Regional, 1957. In: Módulo, 1957. 